Y/LB-16,036, Rev. 1

\title{
RECYCLED URANIUM MASS BALANCE PROJECT \\ Y-12 NATIONAL SECURITY COMPLEX SITE REPORT
}

December 2000

\author{
Prepared by the \\ Y-12 National Security Complex \\ Post Office Box 2009, Oak Ridge, Tennessee \\ 37831 \\ Managed by \\ BWXT Y-12, L.L.C. \\ for the \\ U.S. DEPARTMENT OF ENERGY \\ Under contract DE-AC05-00OR22800
}




\section{DISCLAIMER}

This report was prepared as an account of work sponsored by an agency of the United States Government. Neither the United States Government nor any agency thereof, nor any of their employees, makes any warranty, express or implied, or assumes any legal liability or responsibility for the accuracy, completeness, or usefulness of any information, apparatus, product, or process disclosed, or represents that its use would not infringe privately owned rights. Reference herein to any specific commercial product, process, or service by trade name, trademark, manufacturer, or otherwise, does not necessarily constitute or imply its endorsement, recommendation, or favoring by the United States Government or any agency thereof. The views and opinions of authors expressed herein do not necessarily state or reflect those of the United States Government or any agency thereof. 


\title{
RECYCLED URANIUM MASS BALANCE PROJECT Y-12 NATIONAL SECURITY COMPLEX SITE REPORT
}

\author{
Prepared for the \\ U. S. Department of Energy \\ Office of Uranium and Engineering Services
}

December 2000

\author{
Prepared by the \\ Y-12 National Security Complex \\ Post Office Box 2009, Oak Ridge, Tennessee 37831 \\ Haselwood Enterprises, Inc. \\ under subcontract $\mathbf{4 5 0 0 0 0 1 4 0 7}$ \\ Managed by \\ BWXT Y-12, L.L.C. \\ for the \\ U.S. DEPARTMENT OF ENERGY \\ Under contract DE-AC05-00OR22800
}


This page intentionally left blank. 


\section{TABLE OF CONTENTS}

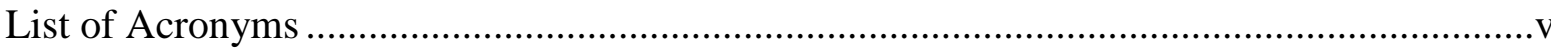

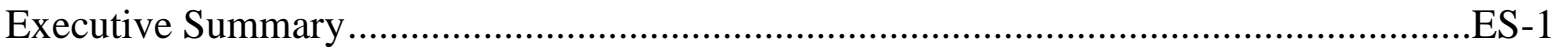

1.0 Y-12 Complex Mass Balance Project..................................................................... 1-1

1.1 Project Overview ........................................................................................ 1-1

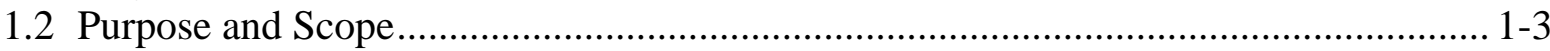

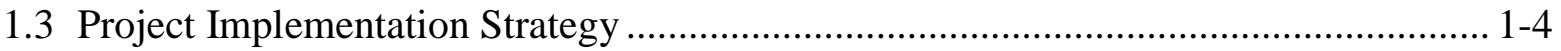

2.0 Site Historical Overview ....................................................................................... 2-1

2.1 Background.................................................................................................. 2-1

2.2 Characterization of RU Streams Received at the Y-12 Complex............................. 2-1

2.3 Key Uranium Processing Facilities at the Y-12 Complex ........................................ 2-3

2.4 Y-12 Complex Operations Involving RU........................................................ 2-8

2.5 Concentrating Processes ........................................................................................ 2-9

2.6 Activities Where Workers Were Likely to Be in Contact with RU through Direct Physical Contact or Airborne Dust .................................................................... 2-11

2.7 Worker Radiological Protection Programs ....................................................... 2-22

2.8 Environmental Impact of Recycled Uranium Constituents................................... 2-26

2.8.1 Historical Radionuclide Releases from Current DOE-ORO Facilities............ 2-26

2.8.2 Environmental Radioactivity Levels News Releases ..................................... 2-28

2.8.3 DOE Joint Task Force on Uranium Recycle Materials Processing ................. 2-33

2.8.4 Oak Ridge Dose Reconstruction Project........................................................ 2-34

3.0 Recycled Uranium Mass Flow........................................................................ 3-1

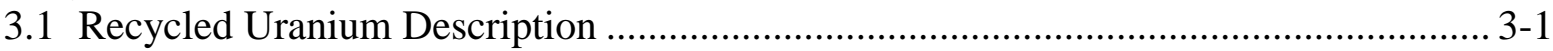

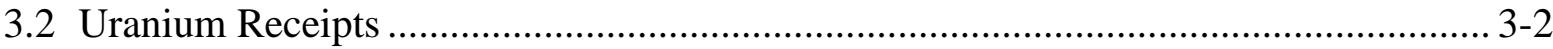

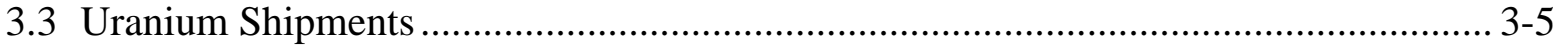

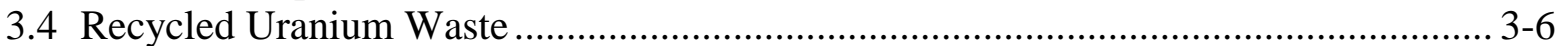

3.5 Recycled Uranium Scrap ............................................................................ 3-6

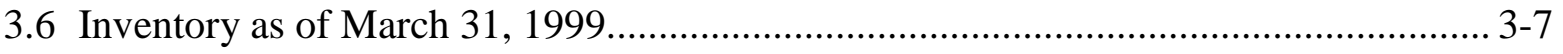

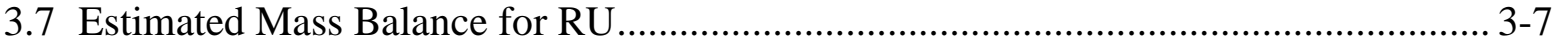

4.0 Constituents in Recycled Uranium ...................................................................... 4-1

4.1 Information Search and Data Sources .............................................................. 4-1

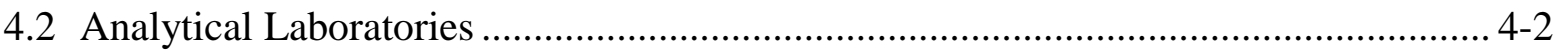

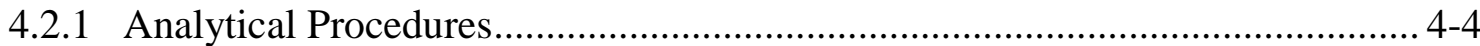

4.2.2 Analytical Methods and Errors................................................................... 4-4

4.3 Historic Standards and Specifications for Transuranics and Fission Products in Recycled Uranium ....................................................................................... 4-5

4.3.1 Historic Standards/Specifications (early years to 1985) …............................... 4-6

4.3.2 Historic Standards/Specifications (1986 to 1995) ............................................. 4-9

4.3.3 Y-12 Complex RU Sampling Program........................................................... 4-11 
4.3.4 Savannah River Specifications

4.4 Analytical Results for TRU Elements and Fission Products in Recycled Uranium Materials Received at the Y-12 Complex........................................................... 4-16

4.4.1 Recycled Enriched Uranium from the Savannah River Site (SRS) ................. 4-16

4.4.2 Recycled Uranium from the Idaho Chemical Processing Plant (ICPP) ........... 4-25

4.5 Analytical Results for TRU Elements and Fission Products in Recycled Uranium

Process Streams and Waste Streams at the Y-12 Complex...................................... 4-28

4.5.1 Process Streams ............................................................................... 4-28

4.5.2 Waste Streams ...................................................................................... 4-35

4.6 Analytical Results for TRU Elements and Fission Products in Facilities and

Equipment in Which RU Was Processed at the Y-12 Complex ................................ 4-39

4.7 Analytical Results for TRU Elements and Fission Products in Material Releases Associated with RU at the Y-12 Complex

4.8 Analytical Results for TRU Elements and Fission Products in Recycled Uranium Materials Shipped from the Y-12 Complex ............................................................ 4-42

4.8.1 Recycled Enriched Uranium Metal for the Savannah River Site (SRS) .......... 4-42

4.8.2 Y-12 Complex Metal Product Derived from Savannah River Recycled

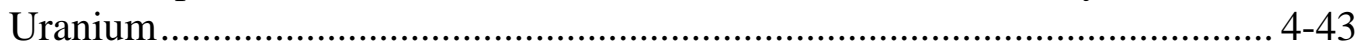

4.8.3 Y-12 Complex Metal Product Derived from ICPP Recycled Uranium ............ 4-47

5.0 Mass Balance Activities ................................................................................................ 5-1

5.1 Estimated Overall Mass Balance of Recycled Uranium ............................................ 5-1

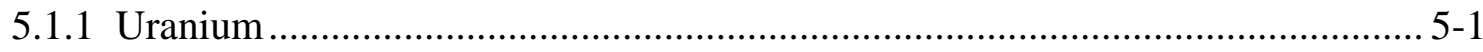

5.1.2 Plutonium and Neptunium...................................................................... 5-2

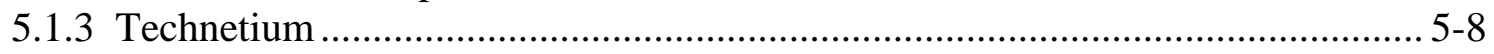

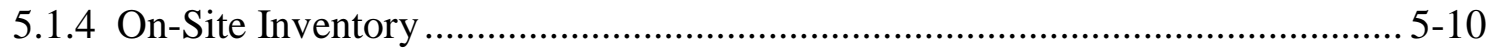

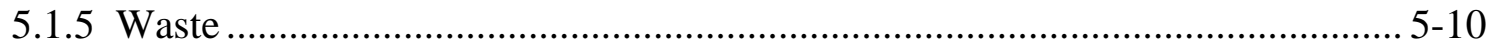

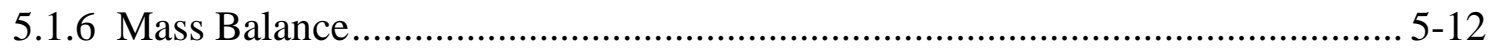

5.2 Potential Areas of Concentration............................................................................ 5-13

5.3 Potential for Worker Exposure ........................................................................ 5-14

5.4 Potential for Environmental Contamination............................................................. 5-17

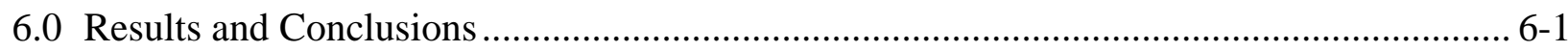

6.1 Explanation of Recycled Uranium Flow Paths ........................................................... 6-1

6.1.1 Flow of RU into the Y-12 Complex .......................................................... 6-1

6.1.2 Flow of RU out of the Y-12 Complex....................................................... 6-1

6.1.3 Flow of RU within the Y-12 Complex .............................................................. 6-2

6.2 Evaluation of Activities that Involved Potential Worker Exposure to

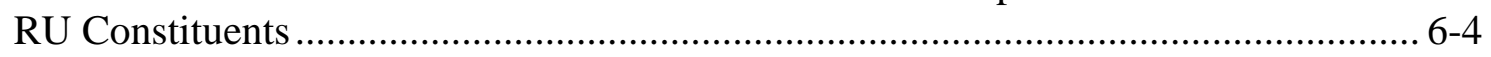

6.3 Identification and Evaluation of Processes or Facilities that Involved Potential

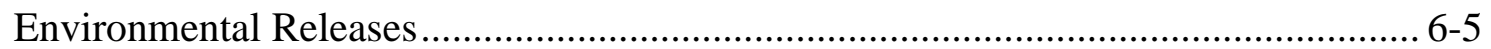

6.4 Discussion of Data Sources ............................................................................................ 6-5

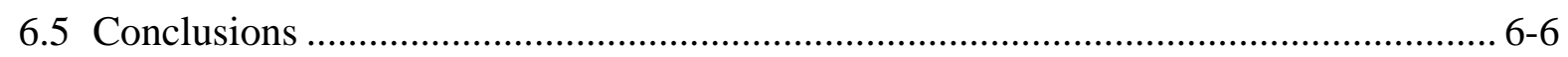

6.5.1 Potential Personnel Exposure .................................................................... 6-6

6.5.2 Potential Environmental Release …………………........................................ 6-6 
7.0 References.

Appendix A. De Minimis Calculation ............................................................................ A-1

Appendix B. Occupational Exposure Potential Methodology ................................................ 
This page intentionally left blank. 


\section{LIST OF ACRONYMS}

$\begin{array}{ll}\mu \mathrm{g} / \mathrm{g} \mathrm{U} & \text { micrograms per gram of total uranium } \\ \mathrm{AEC} & \text { Atomic Energy Commission } \\ \mathrm{Al} & \text { aluminum } \\ \mathrm{Al}\left(\mathrm{NO}_{3}\right)_{3} & \text { aluminum nitrate } \\ \text { ALARA } & \text { as low as reasonably achievable } \\ \text { CAI } & \text { cinnamylideneindene } \\ \text { BCBG } & \text { Bear Creek Burial Grounds } \\ \text { CEUSP } & \text { Consolidated Edison Uranium Solidification Program } \\ \text { cfm } & \text { cubic feet per minute } \\ \text { DAC } & \text { derived air concentrations } \\ \text { DOE } & \text { U.S. Department of Energy } \\ \text { DOE-ORO } & \text { DOE Oak Ridge Operations } \\ \text { dpm } & \text { disintegrations per minute } \\ \text { DU } & \text { depleted uranium } \\ \text { EP } & \text { exposure potential } \\ \text { EPA } & \text { Environmental Protection Agency } \\ \text { ERDA } & \text { Energy Research and Development Administration } \\ \text { EU } & \text { enriched uranium } \\ \text { HEU } & \text { highly enriched uranium } \\ \text { HNO } & \text { nitric acid } \\ \text { IAEA } & \text { International Atomic Energy Agency } \\ \text { ICPP } & \text { Idaho Chemical Processing Plant } \\ \text { IDMS } & \text { Isotope Dilution Mass Spectrometry } \\ \text { ITX } & \text { isotuxene } \\ \text { LEU } & \text { low-enriched uranium } \\ \text { LIMS } & \text { Laboratory Information Management System } \\ \text { LLW } & \text { low-level waste } \\ \text { LMES } & \text { Lockheed Martin Energy Systems } \\ \text { MBR } & \text { Material Balance Reports } \\ \text { MPC } & \text { Maximum Permissible Concentration } \\ \text { MPL } & \text { Maximum Permissible Level } \\ \text { MT } & \text { metric tons } \\ \text { MTU } & \text { metric tons of uranium } \\ \text { MUF } & \text { material unaccounted for } \\ \text { NaOH } & \text { sodium hydroxide } \\ \text { NASA } & \text { National Aeronautics and Space Administration } \\ \text { NBS } & \text { National Bureau of Standards } \\ \text { NCRP } & \text { National Committee on Radiation Protection } \\ \text { NFS } & \text { Nuclear Fuel Services } \\ \text { NMC\&A } & \text { Nuclear Materials Control and Accountability } \\ \text { Np } & \text { neptunium } \\ \text { NPDES } & \text { National Pollutant Discharge Elimination System } \\ & \end{array}$




\begin{tabular}{|c|c|}
\hline NU & Natural Uranium \\
\hline OEP & Occupational Exposure Potential \\
\hline ORGDP & Oak Ridge Gaseous Diffusion Plant \\
\hline ORHASP & Oak Ridge Health Agreement Steering Panel \\
\hline ORIGEN & Oak Ridge Isotope Generation \\
\hline ORNL & Oak Ridge National Laboratory \\
\hline ORR & Oak Ridge Reservation \\
\hline PAL & Plant Action Level \\
\hline PGDP & Paducah Gaseous Diffusion Plant \\
\hline ppb & parts per billion \\
\hline ppm & parts per million \\
\hline $\mathrm{Pu}$ & plutonium \\
\hline RADCON & Radiological Control Organization \\
\hline RCG & Radiation Concentration Guides \\
\hline RCRA & Resource Conservation Recovery Act \\
\hline RF & Rocky Flats \\
\hline RPG & Radiation Protection Guides \\
\hline RSD & Radiation Safety Department \\
\hline RU & recycled uranium \\
\hline SA & specific activity \\
\hline SNM & special nuclear material \\
\hline SRO & Savannah River Operations \\
\hline SRP & Savannah River Plant \\
\hline SRS & Savannah River Site \\
\hline TBP & tributyl phosphate \\
\hline Tc & technetium-99 \\
\hline TIMS & Thermal Ionization Mass Spectrometry \\
\hline TRU & transuranic (transuranics) \\
\hline TTA & thenoyltrifluoroacetone \\
\hline $\mathrm{UF}_{4}$ & uranium tetrafluoride \\
\hline $\mathrm{UF}_{6}$ & uranium hexafluoride \\
\hline UN & uranyl nitrate $\left[\mathrm{UO}_{2}\left(\mathrm{NO}_{3}\right)_{2}\right]$ \\
\hline UNH & uranyl nitrate hexahydrate $\left[\mathrm{UO}_{2}\left(\mathrm{NO}_{3}\right)_{2} \bullet 6 \mathrm{H}_{2} \mathrm{O}\right]$ \\
\hline $\mathrm{UO}_{2}$ & uranium dioxide \\
\hline $\mathrm{UO}_{3}$ & uranium trioxide \\
\hline VOC & volatile organic compounds \\
\hline wt $\%$ & weight percent \\
\hline WACI & weekly air concentration indices \\
\hline WETF & West End Treatment Facility \\
\hline Y-12 Complex & Y-12 National Security Complex \\
\hline
\end{tabular}




\section{EXECUTIVE SUMMARY}

\section{INTRODUCTION}

This report has been prepared to summarize the findings of the Y-12 National Security Complex (Y-12 Complex) Mass Balance Project and to support preparation of associated U. S. Department of Energy (DOE) site reports. The project was conducted in support of DOE efforts to assess the potential for health and environmental issues resulting from the presence of transuranic (TRU) elements and fission products in recycled uranium (RU) processed by DOE and its predecessor agencies. The United States government used uranium in fission reactors to produce plutonium and tritium for nuclear weapons production. Because uranium was considered scarce relative to demand when these operations began almost 50 years ago, the spent fuel from U.S. fission reactors was processed to recover uranium for recycling.

Uranium that has been irradiated in reactors contains TRU elements [e.g., plutonium $(\mathrm{Pu})$ and neptunium-237 (Np)], fission products [e.g., technetium-99 (Tc)], and reactorgenerated uranium products [e.g., uranium-236 $\left.\left({ }^{236} \mathrm{U}\right)\right]$. Following chemical processing to extract various isotopes of $\mathrm{Pu}$ and tritium, as well as to recover uranium for reuse, trace quantities of $\mathrm{Pu}, \mathrm{Np}, \mathrm{Tc}$, and ${ }^{236} \mathrm{U}$ remain in the RU stream. These constituents make the RU stream more radioactive than natural uranium. Thus, the processing and re-enrichment of RU may present an increased potential for personnel and environmental exposure greater than that normally associated with the processing of unirradiated uranium.

In response to these concerns, DOE initiated an effort to identify all situations in which the processing of RU by DOE and its predecessor agencies could have created an increased potential for exposure of workers and/or significant increased environmental exposure. The first step in this process involves the "mass balance review."

The Y-12 Complex Mass Balance Project represents an effort to collect, verify, analyze, and interpret available data to provide an overall accounting, or site mass balance, for Y-12 Complex RU streams. In addition, data on related Y-12 Complex processes and activities and data on $\mathrm{Pu}, \mathrm{Np}, \mathrm{Tc}$, and ${ }^{236} \mathrm{U}$ - the primary constituents of concern in the RU streams - have also been collected, analyzed, and interpreted. Based on available Y-12 Complex records and information about processes and methods of operation and maintenance, the Project Team has identified essentially all those plant activities that (1) created a likelihood of Y-12 Complex workers coming into contact with significant levels of RU constituents through direct physical contact or via airborne dust and/or (2) caused reportable environmental releases of concentrated RU constituents.

The Project Team analyzed data on receipts, shipments, inventories, product, releases, and other categories - along with available analytical data-in the context of documented historical information on Y-12 Complex processes and activities. Understanding of processes known to concentrate $\mathrm{Pu}, \mathrm{Np}$, and $\mathrm{Tc}$ and of activities known to create potential for exposure to these RU constituents provided additional context for analysis. By correlating mass balance data, analytical data, and historical information on Y-12 Complex processes, the team was able to identify specific processes, locations, and time periods of importance for potential worker exposure or environmental releases. These processes, locations, and time 
periods became the focus of additional assessment to determine the situations that had the potential to create exposure hazards for workers and/or significant environmental release.

\section{CHARACTERIZATION OF RU STREAMS RECEIVED AT THE Y-12 COMPLEX}

Uranium streams received at the Y-12 Complex that contained or may have contained RU constituents included:

- highly enriched RU material in the form of uranyl nitrate (UN) solutions or uranium oxide $\left(\mathrm{UO}_{3}\right)$ received from the Savannah River Site (SRS) and the Idaho Chemical Processing Plant (ICPP) and

- slightly depleted RU ${ }^{-}$oxide (including ash and scrap) from the Oak Ridge Gaseous Diffusion Plant (ORGDP), Hanford, and the Paducah Gaseous Diffusion Plant (PGDP.

In accordance with the methodology prescribed by the DOE Project Plan, calculations were performed to estimate for these streams the additional dose presented by constituents in irradiated uranium over that of unirradiated uranium. A fractional dose calculation with a result of $<0.1$ indicates that the additional dose presented by the RU constituents is less than $10 \%$ of the dose expected from doing similar work with uncontaminated weapons-grade uranium. RU streams characterized by a dose fraction of $<0.1$ were deemed de minimis in accordance with the definition established by DOE for the Recycled Uranium Mass Balance Project. For those streams, the radiation-protection measures in place for the presence of uranium are considered adequate for worker protection.

The highly enriched RU from Savannah River and Idaho in the form of uranyl nitrate and uranium oxide was processed at the Y-12 Complex and shipped to Savannah River as highly enriched uranium (HEU) metal for fabrication of production reactor fuel. The primary focus of this document is on the facilities and processes that had the potential for concentrating the RU constituents, relative to the uranium flow, and so presented the greatest potential for increased worker exposure.

Five shipments of slightly enriched RU $\left(0.74 \%{ }^{235} \mathrm{U}\right)$ were received from SRS; however, they were transferred to Fernald within one day to one month of receipt. Since the material was not repackaged, it is not considered to contribute to an increase in personnel exposure.

Slightly depleted RU oxide was received by the Y-12 Complex from ORGDP, Hanford, and PGDP (including fluorination tower ash from PGDP). Documentation and discussion with many individuals who worked at the Y-12 Complex from the 1950s onward indicated that the plant did not have the need for nor the capability of chemically processing this material. Therefore, it is assumed this material was sent to the plant for storage prior to burial or further disposition to other Oak Ridge Operations sites; most of the ash was returned to ORGDP and PDGP. Since these materials were apparently not processed or handled directly at the Y-12 Complex, they are not at this time considered to be potential sources of increased personnel exposure or significant environmental release. Further analysis may be warranted in the future if these materials are determined to have been processed at the Y-12 Complex.

\footnotetext{
${ }^{1}$ Slightly depleted RU recovered from production reactor spent fuel is generally in the range of 0.6 to $0.71 \%$ enrichment.
} 
Depleted uranium metal primarily from Fernald, produced from gaseous diffusion plant tails, has been used extensively in weapons and defense programs at Idaho, Rocky Flats, the Y-12 Complex, and other sites. Identical material received at Idaho was analyzed in the Report on Mass Balance at the Specific Manufacturing Capability Project where it was determined that the fractional dose resulting from the RU constituents is less than $10 \%$ of that of the uranium itself. The ORGDP Mass Balance Report also confirms very low levels of transuranics and Tc in the tails streams. Processing of this material in a manner that concentrated the RU constituents was not performed at the Y-12 Complex; rather, the material was fabricated as is into an end-use form. For this reason, and in accordance with the DOE Project Plan, this depleted uranium metal stream was excluded from further consideration.

\section{RECYCLED URANIUM AT THE Y-12 COMPLEX}

For purposes of the DOE recycled uranium mass balance project, RU has been defined as any uranium that has been irradiated in a reactor and, as a result, contains TRU material (e.g., $\mathrm{Pu}$ and $\mathrm{Np}$ ), fission products (e.g., Tc), and reactor-generated uranium products $\left({ }^{236} \mathrm{U}\right)$. The methodology applied in this Y-12 Complex project for identifying the flow of RU materials includes the criteria of (1) the source site, (2) the isotopic constituents, and (3) the wt-\% assays of the material. Sites identified as RU source sites are the U.S. government facilities that operated production reactors and/or used chemical separation processes to extract uranium from irradiated fuel. Primary source sites are SRS, ICPP, and Hanford. The majority of Y-12 Complex transfers with SRS and ICPP have involved RU (although significant quantities of fresh fuel and sweetener were also shipped to Savannah River). Secondary source sites providing RU materials to the Y-12 Complex are ORGDP and PGDP. The project identified and reviewed RU streams at the Y-12 Complex from the initial introduction of RU into the plant in 1953 until March 31, 1999.

\section{Receipts}

RU was received at the $\mathrm{Y}-12$ Complex from three primary source sites:

- receipts of 125,161 $\mathrm{kg}$ of highly enriched $\boldsymbol{R U}$ as UN solution or U-Al ingots from SRS; this material was processed in the plant's 9212 and/or 9206 facilities,

- receipts of 25,696 $\mathrm{kg}$ of highly enriched $\boldsymbol{R} U$ as UN solution or oxide from ICPP; this material was processed in the plant's 9212 and/or 9206 facilities.

- receipts of 1,502 $\mathrm{kg}$ of slightly depleted $R U$ as oxide from Hanford; the assay associated with this material indicates that it was slightly depleted uranium (DU); this material is believed to have been disposed of on the Oak Ridge Reservation without any processing in Y-12 Complex facilities.

The Y-12 Complex also received RU from the following secondary sites:

\footnotetext{
${ }^{2}$ HEU used to blend with recycled uranium fuel feed to increase its enrichment is referred to as "sweetener."
} 
- receipts of 192,836 $\mathrm{kg}$ of slightly depleted $R U$ from ORGDP; this material is believed to have been stored at the Y-12 Complex temporarily and returned to ORGDP and

- receipts of $38,423 \mathrm{~kg}$ of slightly depleted $R U$ as fluorination tower ash from PGDP; this material is believed to have been disposed of on the Oak Ridge Reservation or returned to PGDP without any processing in Y-12 Complex facilities.

\section{Shipments}

RU streams exited the Y-12 Complex via:

- shipments of 120,384 kg of highly enriched $R U$ as metal product to SRS,

- shipments of 29,614 $\mathrm{kg}$ of $\boldsymbol{R U}$ as slightly depleted fluorination tower ash to PGDP (this material was apparently the ash that had been shipped from PGDP to the Y-12 Complex and stored at the plant), and

- shipments of 192,836 kg of slightly depleted $R U$ to ORGDP (these represent the return of material to ORGDP).

\section{Inventory}

As of March 31, 1999, approximately 13 MT of highly enriched RU remained in the Y-12 Complex inventory.

\section{Summary}

The estimated mass balance for highly enriched RU, which is of most concern for worker exposure and is the primary focus of this project, is summarized in Table ES-1. A discrepancy in the mass balance between receipts and shipments (plus inventory and waste) reflects an inability to precisely distinguish between RU and non-RU shipments and receipts involving the Y-12 Complex and Savannah River. Shipments of fresh fuel (non-RU) and sweetener (also non-RU) were made from the Y-12 Complex to Savannah River along with RU shipments. The only way to distinguish between these RU and non-RU streams using available records is by enrichment level. Shipments of $\leq 90 \%$ enrichment were assumed to be RU. Shipments of $>90 \%$ enrichment were assumed to be non-RU fresh fuel or sweetener. This methodology using enrichment level to distinguish between RU and non-RU results in good estimates of RU flows that are reasonably consistent with Savannah River estimates. Although this is the best available means of distinguishing RU streams, this method does leave a difference of approximately 17.3 MTU between receipts and shipments.

Slightly depleted RU streams received by the Y-12 Complex from ORGDP and PGDP are believed to have been returned to the shipping site or disposed of as waste on the Oak Ridge Reservation. No evidence of Y-12 Complex processing of this material was identified in the historical records reviewed by the Project Team. 
Table ES-1 Estimated Mass Balance for Highly Enriched RU

\begin{tabular}{|c|c|c|}
\hline & $\begin{array}{l}\text { RU Received } \\
\text { kg U }\end{array}$ & $\begin{array}{l}\text { RU Shipped } \\
\text { kg U }\end{array}$ \\
\hline Savannah River & 125,161 & 120,384 \\
\hline ICPP & 25,696 & 0 \\
\hline TOTAL & 150,857 & 120,384 \\
\hline Total RU Shipped & & 120,384 \\
\hline RU Inventory (as of $3 / 31 / 99$ ) & & 13,082 \\
\hline Estimated RU Waste & & $\sim 100$ \\
\hline TOTAL & 150,857 & 133,566 \\
\hline Difference* $^{*}$ & & $\sim 17,300$ \\
\hline
\end{tabular}

* This difference is due to the inability to precisely distinguish between RU and non-RU shipments.

\section{CONSTITUENTS (PU, NP, AND TC) IN RU}

The overall mass balance for highly enriched RU and constituent flow through the Y-12 Complex is summarized in Table ES-2. This table compiles quantities of each constituent based upon the estimating logic presented in Chapter 5.

Table ES-2 Overall Mass Balance for Y-12 Complex Highly Enriched RU

\begin{tabular}{|l|c|c|c|c|c|}
\hline & Receipts & Shipments & Inventory & Waste & Difference \\
\hline $\mathrm{RU}(\mathrm{kg} \mathrm{U})$ & 150,857 & 120,384 & 13,082 & $\sim 100$ & $\sim 17,300$ \\
\hline $\mathrm{Pu}(\mathrm{g})$ & 0.051 & 0.033 & 0.002 & $\sim 0.01$ & $\sim 0$ \\
\hline $\mathrm{Np}(\mathrm{g})$ & 3,666 & 1,073 & 121 & 270 & $2,200(-300)^{*}$ \\
\hline $\mathrm{Tc}(\mathrm{g})$ & 14,499 & 12,279 & 1,365 & 3,200 & $-2,345(335)^{\dagger}$ \\
\hline
\end{tabular}

* The Np difference is $-300 \mathrm{~g}$ if it is assumed that the reported $1.75 \mathrm{Ci}(2,500 \mathrm{~g}) \mathrm{Np}$ was buried in the Bear Creek Burial Grounds as solid waste or shipped off site to another DOE facility.

${ }^{\dagger}$ The Tc difference is $340 \mathrm{~g}$ if it is assumed that most Tc found in the southeast $S-3$ Pond came from ORGDP and that Tc is not included in receipts.

Based upon Y-12 Complex records of highly enriched RU receipts and shipments, material remaining in inventory, and determinations regarding quantities in disposal, there remain no more than trace quantities of Pu not accounted for.

In contrast, the overall mass balance cannot account for 2,200 $\mathrm{g}$ of $\mathrm{Np}$. In the historical plant record, reference is made to discharge of $2,500 \mathrm{~g}$ ( $1.75 \mathrm{Ci})$ of $\mathrm{Np}$ to the $\mathrm{S}-3$ Ponds. However, the amount of $\mathrm{Np}$ that can be accounted for by sampling and analysis of pond sludge is only $145 \mathrm{~g}$. A similar quantity was found in the WETF sludge. It is known by a few individuals in the plant that an ion exchange column was installed in the uranyl nitrate feed stream to specifically remove $\mathrm{Np}$ from the incoming SRS RU for use in another program. The spent or loaded ion exchange columns were removed from the feed line and sent off-site for Np recovery. Since there was little residual uranium contained on the ion exchange resin, this transaction was not listed as an RU transfer and was not placed in the plant uranium accountability record. Assuming that the 2,500 $\mathrm{g}$ of Np identified in the waste 
management record was indeed separated from the RU stream as suspected and either sent off-site for use elsewhere or buried as a solid waste in the Bear Creek Burial Grounds, the overall mass balance shows $300 \mathrm{~g}$ more $\mathrm{Np}$ than can be accounted for.

The overall Y-12 Complex mass balance shows 2,345 grams more Tc on the plant site than can be accounted for, based on the mass difference between the uranium feed, product, and waste streams. It should be noted that the normal flow of acid waste from the 9212 and 9206 HEU operations to the S-3 Ponds went first into the NE basin. The flow was then routed by overflow pipe to the NW basin, then to the SW basin, and finally into the SE basin. Under this normal design flow pattern, one would expect to find the greatest concentration of Tc in the NE basin and the least in the SE basin. Sludge analysis, however, shows $179 \mathrm{~g}$ of Tc in the NE basin, $184 \mathrm{~g}$ in the NW, $89 \mathrm{~g}$ in the SW, and 2,680 $\mathrm{g}$ in the SE. The apparent discrepancy was explained by a former S-3 Pond manager, who stated that on several occasions Tc liquid waste was discharged directly to the SE basin from 5-gal waste drums received from ORGDP. These Tc residues were removed from the gaseous diffusion cascade from time to time during certain maintenance activities. If it is assumed that essentially all of the Tc in the SE basin came from ORGDP and was not included in the Y-12 Complex RU database, the mass balance difference is $340 \mathrm{~g}$ Tc, or $2 \%$ of the estimated total receipt.

\section{POTENTIAL FLOW PATHS OF RU WITHIN THE Y-12 COMPLEX}

The processing of RU at the Y-12 Complex impacted a number of facilities and locations at the plant site. The primary facilities with significant involvement in processing RU were:

- Building 9212, a large uranium processing complex that performed uranium recovery operations on RU materials and produced RU metal product,

- Building 9206, a large uranium processing facility that also performed uranium recovery operations on RU materials and produced RU metal product,

- Building 9720-5, the Y-12 Complex “warehouse," which received, stored, and shipped uranium materials, including RU,

- S-3 Ponds, four holding ponds for liquid and sludge wastes resulting from processes involving uranium, including both unirradiated and recycled uranium (prior to WETF operation beginning in 1986),

- West End Treatment Facility (WETF), a group of nine tanks/bioreactors for holding and treating Y-12 Complex aqueous nitrate wastes (after the S-3 Ponds were taken out of service) plus four sludge storage tanks, and

- New Hope Pond, a large surface water impoundment designed to capture and retain coal fines and other entrained solids from rainwater and plant secondary wastewaters. 


\section{Building 9212 Complex Processes}

Building 9212 complex processes involved the following pathways:

- receiving UN solution from ICPP (in safe bottles) and from SRS (in tanker trucks)

- weighing SRS tanker trucks (at Building 9929-1)

- sampling UN solution

- pouring UN solution from ICPP safe bottles into "pour-up" stations for transfer to intermediate storage tanks

- $\quad$ pumping UN solution from SRS tanker trucks to 9212

- UN evaporated and concentrated

- manual filling and loading of UN into safe bottles for transfer to 9206 (in the period after 9206 assumed responsibility for certain recovery operations from 9212)

- ICPP $\mathrm{UO}_{3}$ received and dissolved to produce UN (in the period after ICPP began sending $\mathrm{UO}_{3}$ instead of $\mathrm{UN}$ )

- purification of UN via solvent extraction (primary and secondary extraction)

- pumping of solvent extraction raffinate to S-3 Ponds

- feeding of solvent extraction raffinate to 9212 bioreactor

- transporting of solvent extraction raffinate to WETF

- denitration of uranyl nitrate hexahydrate (UNH) to $\mathrm{UO}_{3}$

- maintenance on denitrator or fluid beds

- conversion of $\mathrm{UO}_{3}$ to uranium tetrafluoride $\left(\mathrm{UF}_{4}\right)$ in converted lab muffle furnaces

- removal of dry $\mathrm{UF}_{4}$ from process

- "bomb" reduction of $\mathrm{UF}_{4}$ to uranium metal

- sampling, fracturing, and packaging of uranium metal buttons

- salvage operations for uranium-aluminum (U-Al) alloy from SRS

- metal product shipped from Building 9720-5

\section{Building 9206 Processes}

Building 9206 processes involved the following pathways:

- UN solution "poured-up" into safe tanks

- U-Al ingots received from SRS at Building 9720-5

- dross and sweepings received

- U-Al ingots (or dross/sweepings) dissolved in $\mathrm{NaOH}$ to remove $\mathrm{Al}$; sodium diuranate produced

- sodium diuranate dissolved in nitric acid to produce $\mathrm{UN}$

- $\mathrm{UO}_{3}$ received and dissolved to form $\mathrm{UN}$

- purification of UN via solvent extraction (primary and secondary extraction)

- isolation and transport of raffinate to 9212

- denitration of $\mathrm{UNH}$ to $\mathrm{UO}_{3}$

- maintenance on denitrator or fluid beds

- conversion of $\mathrm{UO}_{3}$ to $\mathrm{UF}_{4}$ 
- removal of dry $\mathrm{UF}_{4}$ from process

- "bomb" reduction of $\mathrm{UF}_{4}$ to uranium metal

\section{Processes Associated with Other Y-12 Complex Facilities}

- $\quad$ capping and closure of S-3 Ponds and sludge removal and closure of New Hope Pond

- treatment of nitrate waste at WETF

- $\quad$ storage of RU materials at Building 9720-5

\section{EVALUATION OF ACTIVITIES THAT INVOLVED POTENTIAL WORKER EXPOSURE TO RU CONSTITUENTS}

Prior to and during the processing of RU, the Y-12 Complex also operated as a uraniumprocessing facility. Careful consideration for worker protection was given to the introduction of RU for processing. A criterion for acceptance was based upon DOE/OR-859,, which in turn was derived from an informal agreement between the Y-12 Complex and SRS. The intent of this criterion was to maintain the relative hazard potential of all non-uranium alpha emitters to less than $7 \%$ of the relative hazard potential of uranium. ${ }^{4}$ With this limitation, it was expected that RU could be safely managed by the measures already in place for processing uranium.

The Project Team carefully analyzed and evaluated 36 activities identified as involving potential for worker exposure. The team assigned the following Occupational Exposure Potential (OEP) scores:

- No Significant OEP

- Low OEP

- Moderate OEP
8 activities

1 activity

27 activities

Most of the potential exposure activities at the Y-12 Complex were found to have a "Moderate" OEP rating as a result of the combined product of a constituent level value of 3 for Savannah River RU or a value of 2 for Idaho RU with a value of 1 or 2 for airborne potential and exposure duration. Certain maintenance activities involving equipment that contained finely divided RU solids were assigned a value of 3 for airborne potential. However, because these types of maintenance activities were not performed very often, the overall OEP was rated "Moderate," with a cumulative score of 9.

In no instance did any identified activity involve a combination of airborne potential, constituent level, and exposure duration that produced an OEP score in the "High" range. Although some activities presented moderate OEP scores, the average derived air concentrations (DAC) for the areas associated with RU was on the order of only $3 \%$ of the plant action level (PAL).

The methodology established for the DOE Mass Balance Project considered ${ }^{236} \mathrm{U}$ an unmonitored isotope, along with $\mathrm{Pu}, \mathrm{Np}$, and Tc. In fact, ${ }^{236} \mathrm{U}$ is generally indistinguishable from other uranium isotopes; it has the same chemical behavior and the same dose

\footnotetext{
${ }^{3}$ Egli, D. et al., The Report of the Joint Task Force on Uranium Recycle Materials Processing, 1985.

${ }^{4}$ Vath and Duerksen, Criteria for Acceptance and Technical Assessment for Acceptance of Enriched Uranium at the Y-12 Plant, April 25, 1996.
} 
consequences as can be seen by comparing uranium DAC values. Monitoring, both in the field and through bioassay, accounts for its presence and correctly assigns dose or risk. Other constituents, such as plutonium, are fundamentally different in that they do not have the same chemical behavior or risk. Their presence could alter the intrinsic risk of handling

recycled uranium. Because ${ }^{236} \mathrm{U}$ was monitored at the $\mathrm{Y}-12$ Complex, the analysis presented here, which used the DOE Mass Balance Project de minimis calculation methodology, estimates the Occupational Exposure Potential (the implied hazard) to be higher than it actually is. A calculation that considers the non-uranium, potentially unmonitored component would at times lead to the conclusion of "No Significant Occupational Exposure Potential" when ${ }^{236} \mathrm{U}$ is more appropriately considered.

\section{EVALUATION OF PROCESSES OR FACILITIES THAT INVOLVED POTENTIAL ENVIRONMENTAL RELEASES}

Various sources that documented the potential environmental impact of RU components from the Y-12 Complex and the Oak Ridge Reservation were identified and reviewed by the Project Team. These reports are summarized in Chapter 2.

Solvent raffinate streams from Building 9212 and 9206 extraction systems - as well as condensed acid streams from the various UN solution evaporators and denitrators-were ultimately discharged to the unlined S-3 Ponds. Chemical analysis of the S-3 Pond sludge indicated the presence of 3,140 $\mathrm{g}$ of Tc, $145 \mathrm{~g}$ of $\mathrm{Np}$, and $<0.1 \mathrm{~g}$ of Pu. The S-3 Ponds were capped in 1986, with the sludge left in place under EPA oversight. Uranium has been detected in groundwater monitoring wells around the S-3 Ponds. Therefore, one can infer that RU constituents also leached into the nearby environment from the ponds. Data from other locations, such as the WETF and New Hope Pond, were analyzed and indicated these sites have no significant potential for environmental releases.

\section{CONCLUSIONS}

\section{Potential Personnel Exposure}

Although the Project Team identified 36 activities as having potential for worker exposure, in no instance did any identified activity produce an OEP score in the "High" range. As a result, the potential for worker exposure to TRU elements and fission products at the Y-12 Complex is considered low to moderate.

Early in its existence, the Y-12 Complex implemented a worker protection program that included worker radiological protection (see Section 2.7). This program incorporated such elements as personnel protective equipment, personnel monitoring, environmental monitoring, work location surveys, work-time limits on jobs with penetrating radiation, excretion rate limits, periodic examinations of personnel, and Plant Action Level limits. The inhalation of radioactive materials was recognized as the most important source of possible exposure at the Y-12 Complex. Consequently, administrative controls were primarily designed to guard against associated hazards.

Worker protection measures in place at the Y-12 Complex likely provided substantial mitigation to the risks introduced by the activities rated as moderate to low in OEP. 
However, dose assessment studies may be warranted as a follow-on activity to provide a more detailed assessment of worker exposure.

\section{Potential Environmental Releases}

Soil and groundwater around the Y-12 Complex is contaminated with various radionuclides as a direct result of the nature of the Y-12 Complex work and past disposal practices. However, the quantities of RU constituents in and around the plant are very small and pose no threat to the immediate environment or the surrounding communities. A clear understanding of the contamination exists, and ongoing environmental programs continue to verify this conclusion. The report of the joint task force assembled by DOE in 1985 to study past and (then) current practices related to the processing of RU reflected similar conclusions. The task force did not disclose any instance at the Y-12 Complex in which the environment was jeopardized or compromised.

An Oak Ridge Dose Reconstruction Project was initiated in 1994 as follow-up to the Oak Ridge Dose Reconstruction Feasibility Study, which recommended a closer examination of past uranium emissions and potential resulting exposures. The Task 6 component of the project involved further evaluation of Oak Ridge uranium operations and effluent monitoring records to determine if uranium releases from the Oak Ridge Reservation likely resulted in off-site doses that warranted further study. The results were documented in the July 1999 Task 6 report. The Task 6 team concluded that earlier estimates of uranium releases had been underestimated. However, based on the decision guidelines from the Oak Ridge Health Agreement Steering Panel, the Task 6 team concluded that while Y-12 Complex uranium releases are candidates for further study, they are not high-priority candidates.

The Task 7 component of the project involved performing qualitative and quantitative screening of various materials of concern at the Y-12 Complex and the other DOE Oak Ridge sites. Materials screened included Np and Tc. Results were reported in the Task 7 report. Based on the analysis of data, the Task 7 team determined that $\mathrm{Np}$ did not warrant further study. Although Tc was identified as one of the potential candidates for further study, it was not determined to be a high-priority candidate.

These analyses, along with other information on environmental consequences from Y-12 Complex operations, identify candidate environmental issues for additional study. However, candidate issues related to the processing of RU have not been determined to be high-priority candidates for further study. 


\subsection{Y-12 COMPLEX MASS BALANCE PROJECT}

\subsection{PROJECT OVERVIEW}

This report has been prepared to summarize the findings of the Y-12 National Security Complex (Y-12 Complex) Mass Balance Project and to support preparation of associated U. S. Department of Energy (DOE) site reports. The project was conducted in support of DOE efforts to assess the potential for health and environmental issues resulting from the presence of transuranic (TRU) elements and fission products in recycled uranium (RU) processed by DOE and its predecessor agencies. The U. S. government used uranium in fission reactors to produce plutonium and tritium for nuclear weapons production. Because uranium was considered scarce relative to demand when these operations began almost 50 years ago, the spent fuel from U.S. production reactors was processed to recover the residual uranium for recycling.

Uranium that has been irradiated in reactors contains TRU elements [e.g., plutonium $(\mathrm{Pu})$ and neptunium-237 (Np)], fission products [e.g., technetium-99 (Tc)], and reactorgenerated uranium products [e.g., uranium-236 $\left.\left({ }^{236} \mathrm{U}\right)\right]$. Following chemical processing to separate and extract $\mathrm{Pu}$, as well as to recover uranium for reuse, trace quantities of $\mathrm{Pu}, \mathrm{Np}$, $\mathrm{Tc}$, and ${ }^{236} \mathrm{U}$ remain in the RU stream. These constituents make the RU stream more radioactive than natural uranium. Thus, the handling, processing, and re-enrichment of RU may present a potential for personnel and environmental exposure greater than that normally associated with the processing of unirradiated uranium.

In response to these concerns, DOE initiated an effort to identify situations in which the processing of RU by DOE and its predecessor agencies could have created an increased potential for exposure of workers and/or significantly increased environmental exposure. The first step in this process involves the "mass balance review." This review attempts to determine how much RU was generated by the U.S. government during a period of approximately 47 years and to determine how the material was distributed among the various weapons plants and laboratories.

DOE's reconstruction of the historical flow and processing of RU includes three fundamental activities:

- determining annual mass flow of RU throughout the DOE system from the start of processing to March 31, 1999,

- identifying the characteristics and constituents (e.g., $\mathrm{Pu}, \mathrm{Np}, \mathrm{Tc}$, and ${ }^{236} \mathrm{U}$ ) in the major uranium streams, and

- at appropriate sites, conducting mass balance activities sufficient to identify any significant implications for personnel or environmental releases.

The DOE mass balance review includes U.S. government sites that were sources for RU (i.e., sites that processed irradiated fuel to recover uranium for recycling); sites that processed $\mathrm{RU}$ or re-enriched the RU stream in the fissile ${ }^{235} \mathrm{U}$ isotope; sites that manufactured weapons components; and other affected sites. As part of its work as a uranium weapons component production facility, the Y-12 Complex performed operations to recover or reuse highly enriched uranium (HEU) from RU that came from reactor returns generated by several 
source sites. From 1953 until 1989, the Y-12 Complex recovered HEU from various uranium solutions, oxides, alloys, and scrap metal and recycled the uranium metal it produced back to DOE production reactors.

The Y-12 Complex's involvement with other sites included:

- receiving highly enriched RU from U.S. government facilities at the Savannah River Site (SRS) and the Idaho Chemical Processing Plant (ICPP) following use of chemical separation processes to extract uranium from irradiated fuel,

- $\quad$ receiving depleted RU in the form of fluorination tower ash from the Paducah Gaseous Diffusion Plant (PGDP) for storage or disposition as waste,

- $\quad$ receiving depleted RU for disposition from the Oak Ridge Gaseous Diffusion Plant (ORGDP) and, in much smaller quantities, from Hanford,

- $\quad$ receiving slightly enriched RU from SRS and shipping the same material without repackaging to Fernald,

- $\quad$ shipping highly enriched RU metal product to SRS for recycling,

- $\quad$ shipping depleted RU to PGDP (returning fluorination tower ash that had been shipped from PGDP and stored at the Y-12 Complex), and

- $\quad$ shipping depleted RU to ORGDP (returning material that had been shipped from ORGDP and stored at the Y-12 Complex).

The processing of RU at the Y-12 Complex impacted a number of facilities and locations at the plant site. The primary facilities with significant involvement in processing RU were:

- Building 9212, a large uranium processing complex that performed uranium recovery operations on RU materials and produced RU metal product,

- Building 9206, a large uranium processing facility that also performed uranium recovery operations on RU materials and produced RU metal product,

- Building 9720-5, the Y-12 Complex “warehouse," which received, stored, and shipped uranium materials, including RU,

- S-3 Ponds, four holding ponds for liquid and sludge wastes resulting from processes involving uranium, including both unirradiated and recycled uranium (prior to WETF operation beginning in 1986),

- West End Treatment Facility (WETF), a group of nine tanks/bioreactors for holding and treating Y-12 Complex aqueous nitrate wastes (after the S-3 Ponds were taken out of service) plus four sludge storage tanks, and

- New Hope Pond, a large surface water impoundment designed to capture and retain coal fines and other entrained solids from rainwater and plant secondary wastewaters.

The Y-12 Complex Mass Balance Project represents an effort to collect, verify, analyze, and interpret available data to provide an overall accounting, or site mass balance, for Y-12 Complex RU streams. In addition, data on related Y-12 Complex processes and activities and data on $\mathrm{Pu}, \mathrm{Np}, \mathrm{Tc}$, and ${ }^{236} \mathrm{U}$ - the primary constituents of concern in the RU stream-have also been collected, analyzed, and interpreted. Based on available plant records and information about processes and methods of operation and maintenance, the Project Team has identified essentially all those plant activities that (1) created a likelihood of Y-12 Complex workers coming into contact with significant levels of RU constituents 
through direct physical contact or via airborne dust and/or (2) caused reportable environmental releases of concentrated RU constituents.

\subsection{PURPOSE AND SCOPE}

The purpose of the Y-12 Complex Mass Balance Project is to support DOE's efforts to identify all situations in which U.S. government processing of RU at the Y-12 Complex could have created significant exposure hazards for workers and/or significant release to the environment. Following the guidance provided in DOE's Mass Balance Project Plan, $\square_{\text {the }}$ Y-12 Complex Project Team has focused on:

- describing the amounts, characteristics, and constituents of the incoming and outgoing RU streams at the Y-12 Complex,

- understanding the historical processes, product specifications, and process activities that involved the primary RU constituents of concern $\left(\mathrm{Pu}, \mathrm{Np}\right.$, Tc, and $\left.{ }^{236} \mathrm{U}\right)$,

- determining the facilities and processes where RU presented an increased potential for worker exposure to RU constituents or led to increased measurable environmental release, and

- determining annual mass balances for RU and for Pu, Np, and Tc to the degree existing data permit.

The project identified and reviewed RU streams at the Y-12 Complex from the initial introduction of RU into the plant in 1953 until March 31, 1999. These streams encompassed a broad spectrum of material forms, including uranyl nitrate $\left[\mathrm{UO}_{2}\left(\mathrm{NO}_{3}\right)_{2}\right]$ solutions, uranium trioxide $\left(\mathrm{UO}_{3}\right)$, uranium-aluminum (U-Al) alloy ingots, uranium scrap, uranium tetrafluoride $\left(\mathrm{UF}_{4}\right)$, uranium metal, solvent extraction raffinate, and a variety of secondary process wastes and residues. The RU flow has been traced from receipt by the Y-12 Complex until disposition by the plant. Efforts have also been made to identify all other DOE sites with which the Y-12 Complex exchanged RU and to determine how the plant worked with them.

To identify the RU streams that most warrant attention, the Project Team discounted RU streams that posed no significant hazard over and above the hazard of similar work performed with unirradiated uranium, in accordance with the methodology and definition prescribed by the DOE Project Plan. These RU streams contained $\mathrm{Pu}, \mathrm{Np}, \mathrm{Tc}$, and ${ }^{236} \mathrm{U}$ constituents at such low levels that the increase in potential radiological dose was less than $10 \%$ of the potential dose presented by unirradiated uranium alone. RU streams that represented final product or waste forms with no additional processing anticipated were also discounted. Since DOE has deemed such end products to be outside the scope of the mass balance project, these RU streams were excluded from further consideration. The process for identifying these RU streams, which include Y-12 Complex product and waste streams, is documented in this report.

\footnotetext{
${ }^{1}$ U.S. Department of Energy, Historical Generation and Flow of Recycled Uranium in the DOE Complex: Project Plan, February 2000.
} 


\subsection{PROJECT IMPLEMENTATION STRATEGY}

An interdisciplinary Project Team was formed to conduct the Y-12 Complex Mass Balance Project. Team members included individuals with extensive experience in nuclear materials control and accountability, Y-12 Complex operations for uranium recovery and processing to uranium metal, process maintenance, health and safety at DOE facilities, nuclear engineering, process engineering, nuclear process waste management, the nuclear fuel cycle, statistical analysis, and data and information management. Guided by information provided in the DOE Project Plan (e.g., the Question Set and the Site Report Outline), the team developed a strategy and process for identifying, collecting, organizing, and analyzing available data and information relevant to the project. Leads were established for major project areas (e.g., site historical overview, RU mass balance activities, and mass balance for constituents of concern), and team members were designated to research and abstract information on specific topics. Formal team meetings were held twice each week to track progress, reconcile data gaps and differences, and discuss project issues.

To identify and retrieve data, the Project Team searched the Y-12 Complex Records Center and a variety of other data collections at theY-12 Complex, including electronic systems and administrative files. Major data sources consulted and analyzed included:

- Nuclear Materials Control and Accountability (NMC\&A) data, including shipping, receiving, and inventory records (e.g., individual form 101 and 741 Nuclear Material Transfer Reports),

- Y-12 Complex historical site reports on shipments and receipts,

- Y-12 Complex reports describing facilities and production processes,

- Y-12 Complex health physics records,

- Y-12 Complex production records,

- Y-12 Complex analytical laboratory records,

- Y-12 Complex internal correspondence reports,

- correspondence between shippers and receivers,

- historical DOE and contractor reports,

- more recent (i.e., post-1995) health physics reports on the site,

- more recent (i.e., post-1995) environmental survey reports on the site, and

- interviews with Y-12 Complex personnel with direct experience in RU-related operations.

The Project Team analyzed data on receipts, shipments, inventories, product, releases, and other categories - along with available analytical data-in the context of documented historical information on Y-12 Complex processes and activities. Understanding of processes known to concentrate $\mathrm{Pu}, \mathrm{Np}$, and $\mathrm{Tc}$ and of activities known to create potential for exposure to these RU constituents provided additional context for analysis. By correlating mass balance data, analytical data, and historical information on Y-12 Complex processes, the team was able to identify specific processes, locations, and time periods of importance for potential worker exposure or environmental releases. These processes, locations, and time periods became the focus of additional assessment to determine the situations that had the potential to create exposure hazards for workers and/or significant environmental release. 
For some areas that presented gaps in data that could not at present be filled by research, the Project Team developed estimates for quantities of RU and RU constituents brought into the plant. These estimates are based on extrapolations from other site reports and actual data and represent (1) application of known data from similar material and/or circumstances or (2) application of known data from a specific time period over a longer or a shorter period of time. All such estimates and their bases are specifically identified in this report.

The RU identified in this report as having been received, processed, or shipped by the Y-12 Complex reflects the classical definition of reprocessed uranium: uranium that has been irradiated in reactors and subsequently processed to recover uranium for reuse in the DOE complex. Some DOE sites have labeled all material shipped or received during certain periods or from certain facilities as RU. As a result, there exist some discrepancies among sites regarding quantities of RU shipments and receipts that may need to be resolved. This report has been developed to identify and address the significant sources and quantities of $\mathrm{RU}$ at the Y-12 Complex from the standpoint of potential worker exposure or environmental consequences.

In some cases, the analytical data or calculations presented contain more significant figures than warranted by the precision of the information or methodology. But these are retained in this document, when available, for information purposes. 
This page intentionally left blank.

1-6 


\subsection{SITE HISTORICAL OVERVIEW}

\subsection{BACKGROUND}

Established in 1942, the Oak Ridge Reservation (ORR) occupies approximately 34,500 acres within the city boundaries of Oak Ridge, Tennessee. Of the three major DOE facilities on the ORR, the Y-12 Complex serves as the primary location for Defense Program missions. The Y-12 Complex industrial plant occupies approximately 3,400 acres, with a surrounding buffer zone of an additional 2,800 acres (Fig. 2.1-1). The plant is situated in Bear Creek Valley near the eastern boundary of the ORR, approximately three miles from the population center of the city of Oak Ridge. The plant site is bounded on the south by Chestnut Ridge and on the north by Pine Ridge. This site was originally chosen for the Electromagnetic Plant, which initially occupied 825 acres. The Electromagnetic Plant used staged calutrons (production mass spectrographs) to produce enriched

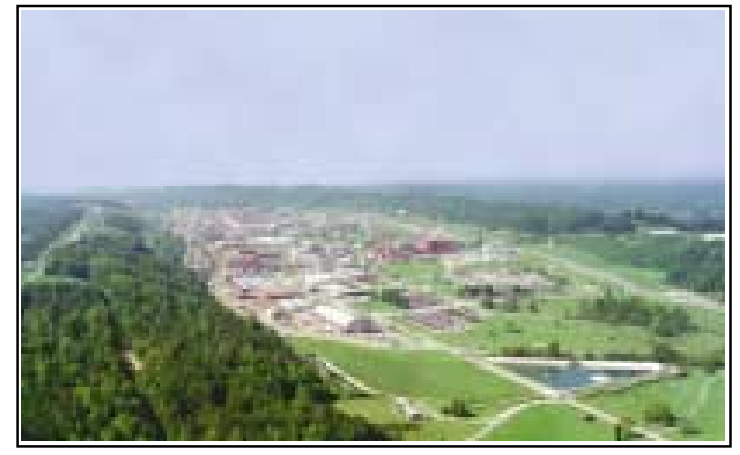

Fig. 2.1-1 The Y-12 Complex. uranium for the Manhattan Project.

After the electromagnetic uranium enrichment process was rendered obsolete by the gaseous diffusion process in the mid1940s, the Y-12 Complex became an enriched uranium weapons component production facility. Since then, the Y-12 Complex has become a center for handling, processing, manufacturing, assembling, storing, and disassembling uranium material and nuclear weapons components. Material processing has included the recovery of highly enriched recycled uranium (RU) from reactor returns. Today, the Y-12 Complex's mission primarily consists of dismantling nuclear weapons components and serving as DOE's primary repository for highly enriched uranium (HEU).

\subsection{CHARACTERIZATION OF RU STREAMS RECEIVED AT THE Y-12 COMPLEX}

Uranium streams received at the Y-12 Complex that contained or may have contained RU constituents included:

- highly enriched RU material in the form of uranyl nitrate solutions or uranium oxide received from Savannah River and ICPP and

- slightly depleted RU oxide (including ash and scrap) from ORGDP, Hanford, and PGDP. 
In accordance with the methodology prescribed by the DOE Project Plan, calculations were performed to estimate for these streams the additional dose presented by constituents in irradiated uranium over that of unirradiated uranium. A fractional dose calculation with a result of $<0.1$ indicates that the additional dose presented by the RU constituents is less than $10 \%$ of the dose expected from doing similar work with uncontaminated weapons-grade uranium. RU streams characterized by a dose fraction of $<0.1$ were deemed de minimis in accordance with the definition established by DOE for the Recycled Uranium Mass Balance Project. For those streams, the radiation-protection measures in place for the presence of uranium are considered adequate for worker protection (see Appendix A).

The highly enriched RU from Savannah River and Idaho in the form of uranyl nitrate and uranium oxide was processed at the Y-12 Complex and shipped to Savannah River as HEU metal for fabrication of production reactor fuel. The primary focus of this document is on the facilities and processes that had the potential for concentrating the RU constituents, relative to the uranium flow, and so presented the greatest potential for increased worker exposure.

Slightly depleted RU oxide was received by the Y-12 Complex from ORGDP, Hanford, and PGDP (including fluorination tower ash from PGDP). Documentation and discussion with many individuals who worked at the Y-12 Complex from the 1950s onward indicated that the plant did not have the need for nor the capability of chemically processing this material. Therefore, it is assumed this material was sent to the plant for storage prior to burial or further disposition to other Oak Ridge Operations sites; most of the ash was returned to PDGP. Since these materials were apparently not processed or handled directly at the Y-12 Complex, they are not at this time considered to be potential sources of increased personnel exposure or significant environmental release. Further analysis may be warranted in the future if these materials are determined to have been processed at the Y-12 Complex.

Depleted uranium metal from Fernald, produced from gaseous diffusion plant tails, has been used extensively in weapons and defense programs at Idaho, Rocky Flats, the Y-12 Complex, and other sites. Identical material received at Idaho was analyzed in the Report on Mass Balance at the Specific Manufacturing Capability Project ${ }^{2}$ where it was determined that the fractional dose resulting from the RU constituents is less than $10 \%$ of that of the uranium itself. The ORGDP Mass Balance Report also confirms very low levels of transuranics and Tc in the tails streams. Processing of this material in a manner that concentrated the RU constituents was not performed at the Y-12 Complex; rather, the material was fabricated as is into an end-use form. For this reason, and in accordance with the DOE Project Plan, this depleted uranium metal stream was excluded from further consideration.

\footnotetext{
${ }^{1}$ U.S. Department of Energy, Historical Generation and Flow of Recycled Uranium in the DOE Complex, Appendix A, February 2000.

${ }^{2}$ Barg, Don C., TRU and DU at SMC, Report on Mass Balance at SMC, June 19, 2000.
} 


\subsection{KEY URANIUM-PROCESSING FACILITIES AT THE Y-12 COMPLEX}

Six locations within the Y-12 Complex were involved in the highly enriched RUprocessing operations (Fig. 2.3-1). Until the early 1970s, chemical processing of highly enriched RU occurred in the large 9212 complex. Afterward, chemical processing, following virtually the same procedures and using nearly identical equipment, occurred in Building 9206. Enriched uranium product was stored in Building 9720-5. The S-3 Ponds served as impoundment for process wastewater until the mid-1980s; the four earthen basins comprising the S-3 Ponds had no direct discharge to any local creek or river tributary. After the ponds were closed, RU-process wastewater was treated by a variety of methods at the West End Treatment Facility (WETF). Treated wastewater was discharged from WETF to East Fork Poplar Creek. New Hope Pond served as a surfacewater impoundment that captured entrained solids from rainwater and secondary wastewaters.

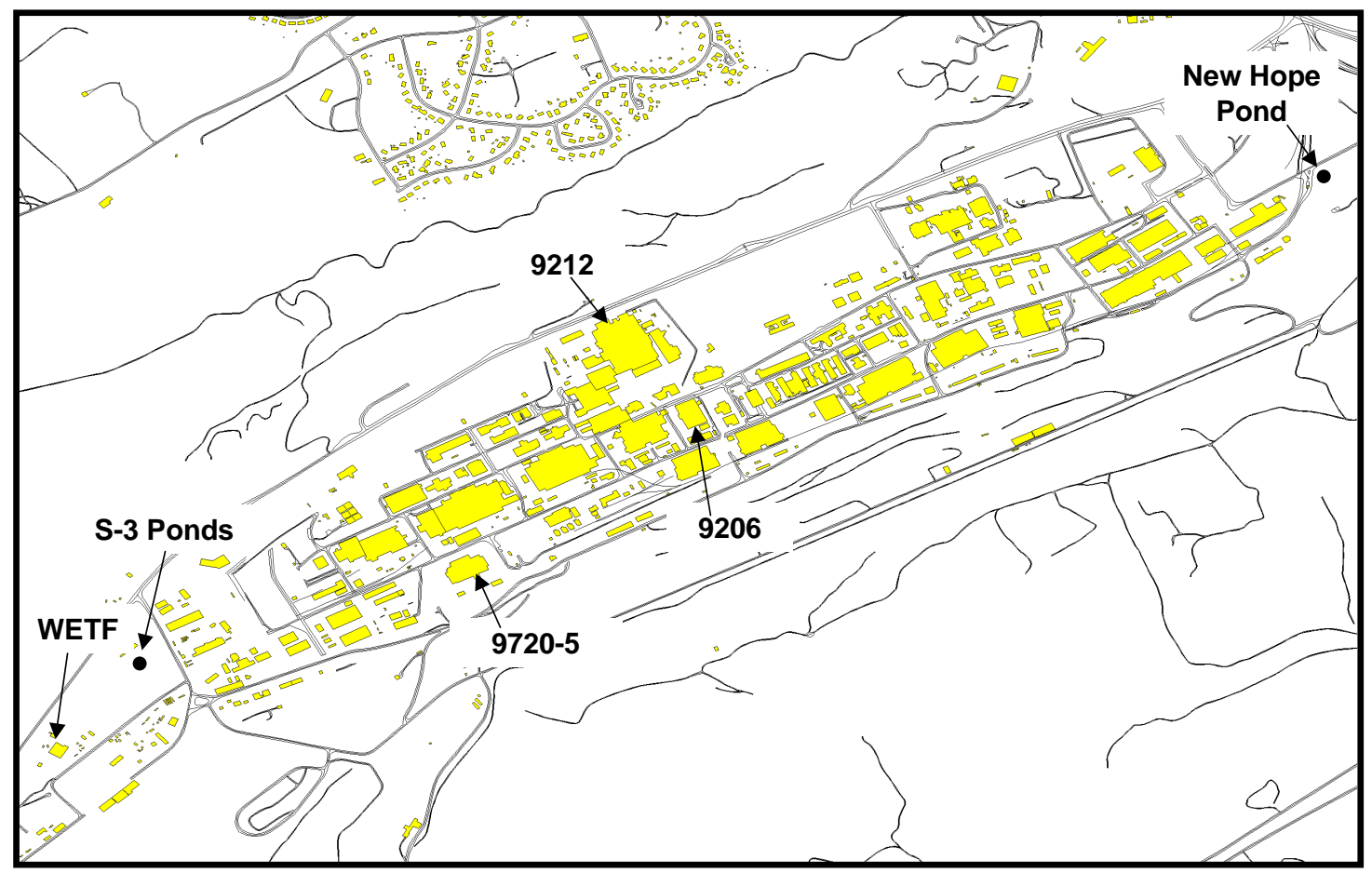

Fig. 2.3-1 RU Operations Occurred in Six Facilities at the Y-12 Complex.

\section{Building 9212 Complex}

The 9212 Complex processes HEU to produce uranium metal and oxide suitable for storage, reactor fuels, specialty compounds, or weapons components. The recovery and purification operations extract HEU from uranium-bearing scrap and waste and process it into forms suitable for reuse or accountability. The majority of this scrap and waste is generated by the Y-12 Complex's weapons production or disassembly operations and by 
the recovery processes themselves. Some scrap and waste is generated through nuclear materials production; additional scrap is received from other sites for recovery or for accountability of the uranium it contains. The nature of these uranium-bearing materials varies from combustible and noncombustible solids to aqueous and organic solutions. Concentrations of uranium vary in these materials from pure uranium compounds and alloys to trace quantities [parts per million (ppm) levels] in combustibles and solutions.

The 9212 Complex includes Buildings 9212, 9809, 9812, 9818, 9815, and 9980. Over 100 operations or processes have been, or are capable of being, performed within this complex.

The largest building, 9212 was constructed in the early 1940s. The building is a multistory facility constructed of structural steel frame infilled at the perimeter with thick hollow clay tile. The substructure basement is constructed of reinforced concrete. The original structure consisted of a central building (the "Headhouse") 72 feet wide by 308 feet long (N-S direction) and four parallel wings projecting from the east side of the Headhouse, each 36 feet by 264 feet (A, B, C, and D Wings); open space between the wings was designed to mitigate the impact of a postulated criticality accident or chemical explosion.

The original mission of Building 9212 during World War II was to recover HEU from the electromagnetic separation project. Recovery was accomplished in the four wings.

Following World War II, the 9212 building was expanded through a series of structural modifications and additions to accommodate the increased production of uranium from the Oak Ridge Gaseous Diffusion Plant (ORGDP) and to provide capability for the recovery of uranium from waste materials. In 1948, new structures were erected in the spaces between the existing A, B, C, and D Wings (these were called the A-1, B-1, and C-1 Wings) and adjoining D Wing (the D-1 Wing). Next, a single story 113-foot-wide by 400-foot-long steel frame structure was added in 1951 (the E Wing) adjacent to the D-1 Wing and north of the Headhouse. The E Wing was added to facilitate the casting and machining of uranium components. Other, less-extensive modifications and additions have subsequently been made.

In the late 1950s, continuous solvent extraction equipment was installed in the B-1 Wing and "penthouses" were raised on the roof to house 30-foot-long extraction columns. This period covered the transition from small-scale batch operations to the existing continuous recovery equipment in use today.

The uranium hexafluoride conversion facility in the D Wing was shutdown in 1964, essentially halting the introduction of new HEU metal into the weapons stockpile. Since 1964, all HEU weapons components have been produced with uranium recovered from retired weapon subassemblies and production scrap. Special projects, such as the production of fuel for the NASA Rover Project and various research reactors, were accomplished in Building 9212 from time to time.

A number of facility modifications have been performed to reduce the environmental impact of the operations. These modifications were both in response to changing regulations as well as an effort to maintain exposures to ionizing radiation as low as reasonably achievable (ALARA). 
Building 9212 currently performs four primary functions:

- casting of HEU metal (for weapons, reactors, storage, or other uses),

- accountability of HEU from plant activities (quality evaluation, casting, storage),

- recovery of HEU to a form suitable for storage (from plant activities and commercial scrap), and

- serving as the U.S. source of all HEU used in test, research, or propulsion reactors and for isotope production.

In addition to these primary missions, Building 9212 supports International Atomic Energy Agency (IAEA) sampling of surplus enriched uranium, packaging HEU for offsite shipment, and producing specialized uranium compounds and metal for research reactor fuel.

The recovery and purification process for HEU relies on the unique physical and chemical properties of uranium in a nitric acid system, where uranium forms uranyl nitrate $\left[\mathrm{UO}_{2}\left(\mathrm{NO}_{3}\right)_{2}\right]$, abbreviated $\mathrm{UN}$; when concentrated to the point of crystallization, the nitrate becomes uranyl nitrate hexahydrate $\left[\mathrm{UO}_{2}\left(\mathrm{NO}_{3}\right)_{2} \cdot 6 \mathrm{H}_{2} \mathrm{O}\right]$, abbreviated $\mathrm{UNH}$. The approach to recovery and purification, therefore, consists of chemically changing HEU into a nitrate solution through dissolution, leaching, and other processes and using the chemical properties of uranium to concentrate, purify, extract, and finally convert the HEU into a purified metallic form. The recovery process generally includes the following steps:

1. "Headend" (first-step) operations (Headhouse; B-1, C, and C-1 Wings)

- bulk volume reduction of scrap (mostly burning)

- dissolution of scrap into uranyl nitrate solution

- separation of uranium from non-uranium materials

2. Continuous purification and chemical conversion operations (B-1, C-1, and C-Wings)

- organic solvent extraction

- evaporation

- conversion of uranyl nitrate to $\mathrm{UO}_{3}$

- conversion of $\mathrm{UO}_{3}$ to uranium tetrafluoride $\left(\mathrm{UF}_{4}\right.$ or greensalt)

3. Reduction (E-Wing)

- blending of $\mathrm{UF}_{4}$

- calcium reduction of $\mathrm{UF}_{4}$ powder to uranium metal

4. Special processing (E-Wing)

- special materials production

- accountability of scrap

- scrap dissolution

- packaging of HEU materials for shipment 
5. Waste streams and materials recovery (Buildings 9212, 9809, 9812, 9818, and 9815)

- nitrate recycle

- biodenitrification

- materials storage and handling

- chemical make-up

- organic handling

- neptunium recovery

\section{Building 9206 Complex}

Building 9206 is centrally located in the Y-12 Complex below Building 9212. Approximately 260 feet long and 165 feet wide, this building is a multistory facility constructed in the early 1940s of structural steel infilled with thick hollow clay tile at the perimeter. It has a $43,614-\mathrm{ft}^{2}$ first story with a $19,800-\mathrm{ft}^{2}$ second story in its central portion, a 3,300- $\mathrm{ft}^{2}$ mezzanine, and a $580-\mathrm{ft}^{2}$ penthouse. The 9206 building has been used extensively over its lifetime for the chemical processing of uranium.

Building 9206 has several related structures that house supporting or process services and/or equipment, all of which are considered inclusively as the 9206 Facility. These are 9768, 9720-17, 9409-17, 9510-2, 9767-2, and the east and west tank farm pits.

Enriched uranium processes, activities, and/or missions of the 9206 Facility have included:

- chemical recycle, charge preparation, HEU recovery, and product processing for the electromagnetic process (1945 to 1946);

- recovery of enriched uranium [both HEU and low-enriched uranium (LEU)] from Y-12 Complex programs and many other sites (1947 to 1994);

- production of uranium compounds for other sites (1949 to 1972);

- conversion of $\mathrm{UF}_{6}$ to $\mathrm{UF}_{4}$ to uranium metal for weapons (1954 to 1964);

- casting and machining of HEU metal for weapons (1955 to 1965);

- recovery of HEU from Savannah River Site (SRS) solutions and other scrap for return to SRS as uranium metal (1972 to 1989);

- conversion of excess HEU metal to oxide feed for the Portsmouth Gaseous Diffusion Plant (1980 to 1985); and

- storage of in-process materials (1950 to present).

Non-enriched uranium processes, activities, and/or missions of the 9206 facility have included:

- recycling depleted uranium chips (1951 to late 1950s),

- production of uranium compounds for other sites (1949 to 1972),

- canning of normal-assay uranium slugs for nuclear reactor use (1950 to 1952), and

- storage of in-process materials (1950 to present). 
Non-uranium processes, activities, and/or missions of the 9206 facility have included:

- zirconium processing (1950),

- thorium parts processing (1963),

- graphite flour processing and preparation of special organic compounds [isotuxene (ITX), cinnamylideneindene (CAI), and pitch] in support of the Rover Program (1967 to 1971), and

- radiogenic lead processing (1965 to 1966).

Building 9206 is currently used for in-process materials storage. This will continue to be the function of 9206 until the stored material can be transferred to Building 9212 for processing or transferred to another storage location.

\section{Other Uranium Handling Facilities}

\section{Building 9720-5}

Used as a warehouse for short- and long-term storage of strategic materials, Building 9720-5 was built in 1944 and has been renovated several times. The facility is a singlestory building located in the southwestern portion of the Y-12 Complex. It has a concrete floor elevated about 1 meter above the local grade and five dock areas; air is exhausted unfiltered through roof-mounted fans. The main warehouse dimensions are approximately $150 \mathrm{ft} \times 300 \mathrm{ft}$. Building $9720-5$ is a shipping/receiving facility for special nuclear material (SNM) and the primary storage facility for interim and prolonged lowmaintenance storage of HEU.

\section{S-3 Ponds}

The S-3 Ponds consisted of four unlined earthen basins constructed at the west end of the plant to receive acid wastewater from various Y-12 Complex production operations involving both enriched and depleted uranium streams. These basins were placed into operation around 1951 and were taken out of service in 1984. Various metal impurities and radionuclides stripped from HEU in the 9212 and 9206 solvent extraction steps (approximately $10 \%$ to $30 \%$ of the $\mathrm{RU}, \mathrm{Pu}, \mathrm{Np}$, and Tc) were discharged with the dilute nitric acid and other process-derived acid wastewater to the S-3 Ponds prior to the mid1980s. Uranium-containing process wastewaters from various depleted uranium plant operations were also discharged to the S-3 surface impoundment. The ponds were closed and capped in the mid-1980s.

\section{West End Treatment Facility}

Beginning in the mid-1980s, after discontinuance of the use of the S-3 Ponds, the West End Treatment Facility (WETF) was constructed for treating mixed low-level waste (LLW) and LLW-contaminated wastewater generated by Y-12 Complex production and other DOE ORO processes meeting the facility waste acceptance criteria and Resource 
Conservation Recovery Act (RCRA) Permit-by-Rule regulations. Nitrate wastewater contaminated with enriched uranium (EU) was mixed with much larger quantities of wastewater contaminated with depleted uranium. Consequently, the EU component was diluted to less-than-normal-assay uranium. Treatment methods include hydroxide precipitation of metals, sludge settling and decanting, biodenitrification, bio-oxidation, $\mathrm{pH}$ adjustment, degasification, coagulation, flocculation, clarification, filtration, and carbon absorption. Wastewaters are discharged from the facility under NPDES permit into East Fork Poplar Creek. Contaminated sludges generated by the WETF operations are pumped into one of four large (0.5-million gallon) sludge storage tanks.

\section{New Hope Pond}

In the 1950s, New Hope Pond was constructed and placed in operation to provide a holdup basin on East Fork Poplar Creek at the east end of the Y-12 Complex. The pond facilitated mixing and offered a sampling point for rainwater runoff, once-through cooling water, steam plant boiler blow-down, and secondary production process wastewaters. New Hope Pond was also used as a settling basin to remove entrained coal fines from the Y-12 Complex coal yard. At the same time, the pond functioned to remove any suspended contamination from rainwater, miscellaneous releases from various tank farms and storage yards, and inadvertent releases from process buildings. In 1973, New Hope Pond was dredged, and the sludge was transferred to a basin located on Chestnut Ridge; this process was repeated in the latter 1980s as part of an environmental restoration project. Data from a leach test showed that the sediment was not hazardous (see Section 4.5.2.3).

\subsection{Y-12 COMPLEX OPERATIONS INVOLVING RU}

The RU streams at the Y-12 Complex encompassed a variety of material forms, including uranyl nitrate solutions, molten $\mathrm{UNH}, \mathrm{UO}_{3}, \mathrm{UO}_{2}, \mathrm{UF}_{4}$, uranium metal, uranium alloys, and a variety of associated wastes. These RU streams impacted a number of plant facilities. Those with significant involvement with RU were Buildings 9212, 9206, 9720-5, the S-3 Ponds, and the West End Treatment Facility. New Hope Pond experienced less impact. With the exception of the S-3 Ponds, which have been closed in place and capped, and New Hope Pond, which has been closed after draining and removing the sediment, all of these facilities continue to be used today.

From 1953 until the early 1970s, all processing of SRS and the Idaho Chemical Processing Plant (ICPP) RU material to metal product was performed in Building 9212. From the early 1970s until 1989, most activities involving processing RU material to metal product were performed in Building 9206. In Building 9212, however, there continued to be evaporation and concentration of RU-derived uranyl nitrate solutions before transfer to 9206 and also sampling, fracturing, and packaging of RU-derived metal product prior to shipping.

Typically, SRS shipped uranyl nitrate solution to the Y-12 Complex in tanker trucks with capacities of 3,800-5,000 gallons. After primary evaporation, the material went through purification by solvent extraction, denitration to produce $\mathrm{UO}_{3}$, reduction to $\mathrm{UO}_{2}$, 
hydrofluorination to $\mathrm{UF}_{4}$, and "bomb" reduction to metal. After the metal was cleaned, it was prepared in 9212 for shipment back to SRS from 9720-5 or was stored. From 1972 to the early 1990s, SRS sent scrap from the uranium-aluminum (U-Al) alloy casting process to the Y-12 Complex for processing. This material was dissolved in sodium hydroxide $(\mathrm{NaOH})$ solution to remove the aluminum and produce sodium diuranate solids. The sodium diuranate was dissolved in nitric acid to produce uranyl nitrate solution, which was then purified and converted to metal. The Y-12 Complex also processed furnace dross and floor sweepings from the SRS U-Al casting process. These materials were similarly processed in 9206 by dissolution, purification, and conversion to metal. However, not all of the U-Al material was processed, and some quantities remain in storage at the Y-12 Complex.

From 1953 until the late 1980s, ICPP processed spent Navy, research, and experimental reactor fuel to recover and recycle HEU. The resultant product was shipped to the Y-12 Complex for processing to metal and subsequent shipment to SRS (or storage). Initially, ICPP provided UN solution. However, after a denitrator was installed at ICPP in 1970, ICPP provided RU to the Y-12 Complex as $\mathrm{UO}_{3}$. After undergoing dissolution, the $\mathrm{UO}_{3}$ was processed by the Y-12 Complex through the same steps as the uranyl nitrate solution.

\subsection{CONCENTRATING PROCESSES}

At the inception of the RU processing program at the Y-12 Complex, local radiation safety personnel developed strict limits on the allowable radioactivity that could enter the plant in RU. The plant RU acceptance criteria (see Section 4.3) were expressed in terms of activity ratios derived from allowable radiological limits for uranium, transuranic (TRU) elements, and fission products. As a direct result, control was achieved by limiting the quantities of TRU elements and various reactor fission products in relation to the associated uranium flows. This allowed existing uranium contamination control standards and practices for unirradiated HEU to be used for protection of plant workers from the incremental effects due to the presence of RU constituents. This radiation control philosophy presupposes that the RU constituents do not concentrate to any significant extent in the plant equipment or processes. In instances where significant concentration may occur, modified TRU limits may be required.

The objective of the Y-12 Complex RU work was recovery of HEU from various uranium scrap metals, oxides, and solutions for preparation of uranium metal for the DOE production reactors at SRS. While similar to chemical processing facilities used at Savannah River, Idaho, and Hanford to separate fission products and $\mathrm{Pu}$ from irradiated uranium fuel, the Y-12 Complex processes were designed and operated primarily to recover HEU from unirradiated production scrap and various process residues, remove problematic chemical impurities, such as iron, nickel, chromium, and carbon from the uranium stream, and convert the various uranium forms to uranium metal. The uranium processes were operated to minimize loss of HEU in the various waste streams. Consequently, incoming RU constituents other than uranium were left to distribute across the chemical facilities without any particular process control or design specific to RU. 
The nature of the Y-12 Complex HEU processes is such that the RU constituents were not deliberately concentrated in any stream on an overall mass-to-volume basis. However, when considered on an unirradiated HEU basis, even the smallest RU stream, regardless of the absolute TRU or fission-product content, may become a stream where the TRU or fission products exist as the dominant isotopes whenever the uranium is selectively removed from the process stream. This situation occurred in both 9212 and 9206 operations during primary and secondary solvent extraction purification steps and, to a lesser extent, during acid leaching of certain process solids to recover the uranium. Overall, sizable fractions of the incoming radionuclides followed the uranium through the process and ultimately ended up in the HEU metal product shipped to Savannah River. However, in the waste stream, which was dilute in uranium by volume, TRU became concentrated with respect to uranium mass. The ${ }^{236} \mathrm{U}$ fed to the process in the $\mathrm{RU}$ partitioned with the uranium during all of the process steps because ${ }^{236} \mathrm{U}$, for all practical purposes, is chemically and physically indistinguishable from ${ }^{235} \mathrm{U},{ }^{234} \mathrm{U}$, and ${ }^{238} \mathrm{U}$ isotopes.

As an artifact of the chemical characteristics of TRU elements and fission products of concern in mixed aqueous-organic solutions (specifically, nitric acid-dibutyl carbitol), approximately $10 \%$ to $30 \%$ of the target radionuclides remained in the nitric acid feed stream after solvent extraction (raffinate). However, only a small fraction of the incoming uranium ended up in the primary solvent extraction raffinate stream, as intended. As a net result, even though less than half of the TRU elements and Tc ended up in the raffinate, these RU components were effectively concentrated in the primary waste discharge stream from the recovery operation. The secondary solvent extraction raffinate contained a significantly larger quantity of uranium, but the target radionuclides were still concentrated on a uranium basis, although to a lesser extent than the primary system. The raffinate from the secondary system was recycled back to the headend of the recovery process rather than being discharged.

RU constituents contained in the primary raffinate ultimately ended up in the S-3 Ponds or, after about 1985, in the WETF sludge tanks. Contaminated sludge was allowed to accumulate in the S-3 Ponds for more than 30 years before the ponds were taken out of service. The pond sludge was combined with a large quantity of depleted uranium from other plant operations. These other uranium streams did not contain significant RU. Hence, neither the S-3 Ponds or WETF created a significant RU concentration point (relative to uranium).

Other situations in which the RU constituents may become concentrated (relative to the uranium flow) occur when uranium is selectively removed from certain processgenerated contaminated solids and during process-residue leaching operations, leaving a fraction of the TRU elements and fission products behind. The actual radiological hazard created by such operations is not particularly significant because any radionuclides left behind are fixed in the contaminated solids and relatively immobile. 


\subsection{ACTIVITIES WHERE WORKERS WERE LIKELY TO BE IN CONTACT WITH RU THROUGH DIRECT PHYSICAL CONTACT OR AIRBORNE DUST}

In reviewing Y-12 Complex facilities and processes, the Project Team identified a number of activities that, based on available data and process knowledge, would be expected to present the greatest potential for workers to be exposed to the RU constituents of interest (i.e., ${ }^{236} \mathrm{U}, \mathrm{Pu}, \mathrm{Np}$, and $\mathrm{Tc}$ ). These activities are described in Table 2.6, which is subdivided by areas in which activities took place; the table includes information on time frame and occupational exposure potential (OEP) values. The potential for worker occupational exposure is expressed as High, Moderate, Low, or No Significant potential. These values have been qualitatively determined by the Project Team. To assign these values, the team reviewed activities and considered three parameters: the likelihood of material becoming airborne during the activity, the level of hazardous constituents in the airborne material, and the length of time a worker might be exposed to the airborne material. These were assigned numbers $(0,1,2$, or 3$)$ and the product of the values for the three parameters determined the estimate of High, Moderate, Low, or No Significant (see Appendix B). Activities associated with long-term exposure to high levels of materials with high radiological activity received the highest rating, while short-duration activities in relatively "clean" areas received the lowest rating.

Table 2-6 Activities at the Y-12 Complex with Potential for Worker Exposure to RU

\begin{tabular}{|c|c|c|c|c|}
\hline Location & Activity & Time Frame & Constituents & $\begin{array}{l}\text { Occupational } \\
\text { Exposure } \\
\text { Potential }^{\star}\end{array}$ \\
\hline & \multicolumn{4}{|l|}{ 1. Activities Associated with Building 9212} \\
\hline 9212 & 1A. ICPP UN solution received in safe bottles & $\begin{array}{c}\text { 1953-early } \\
1970 \text { s }\end{array}$ & $\begin{array}{l}0.11 \mathrm{ppb} \mathrm{Pu} \\
4.7 \mathrm{ppm} \mathrm{Np} \\
0.13 \mathrm{ppm} \mathrm{Tc} \\
10 \%{ }^{236} \mathrm{U}\end{array}$ & No Significant \\
\hline $9929-1$ & 1B. SRS tanker truck weighed for gross weight & $1955-1988$ & $\begin{array}{l}0.25 \mathrm{ppm} \mathrm{Pu} \\
0.073 \mathrm{ppm} \mathrm{Np} \\
82 \mathrm{ppm} \mathrm{Tc} \\
27.8 \%{ }^{236} \mathrm{U}\end{array}$ & No Significant \\
\hline $\begin{array}{l}9212 \\
\text { Complex }\end{array}$ & 1C. SRS material sampled & $1953-1988$ & $\begin{array}{l}0.25 \mathrm{ppm} \mathrm{Pu} \\
0.073 \mathrm{ppm} \mathrm{Np} \\
82 \mathrm{ppm} \mathrm{Tc} \\
27.8 \%{ }^{236} \mathrm{U}\end{array}$ & No Significant \\
\hline 9212 & $\begin{array}{l}\text { 1D. ICPP UN solution poured into "pour-up" } \\
\text { stations for transfer to intermediate storage } \\
\text { tanks }\end{array}$ & $\begin{array}{c}\text { 1953-early } \\
1970 \text { s }\end{array}$ & $\begin{array}{l}0.11 \mathrm{ppb} \mathrm{Pu} \\
4.7 \mathrm{ppm} \mathrm{Np} \\
0.13 \mathrm{ppm} \mathrm{Tc} \\
10 \%{ }^{236} \mathrm{U}\end{array}$ & Low \\
\hline $\begin{array}{l}9212 \\
\text { Complex }\end{array}$ & 1E. SRS UN solution pumped to 9212 & $1955-1988$ & $\begin{array}{l}0.25 \mathrm{ppm} \mathrm{Pu} \\
0.073 \mathrm{ppm} \mathrm{Np} \\
82 \mathrm{ppm} \mathrm{Tc} \\
27.8 \%{ }^{236} \mathrm{U}\end{array}$ & No Significant \\
\hline 9212 & $\begin{array}{l}\text { 1F. SRS and/or ICPP UN evaporated and } \\
\text { concentrated }\end{array}$ & $1953-1989$ & $\begin{array}{l}0.25 \mathrm{ppm} \mathrm{Pu} \\
0.073 \mathrm{ppm} \mathrm{Np} \\
82 \mathrm{ppm} \mathrm{Tc} \\
27.8 \%{ }^{236} \mathrm{U}\end{array}$ & Moderate \\
\hline
\end{tabular}


Table 2-6 Activities at the Y-12 Complex with Potential for Worker Exposure to RU

\begin{tabular}{|c|c|c|c|c|}
\hline Location & Activity & Time Frame & Constituents & $\begin{array}{l}\text { Occupational } \\
\text { Exposure } \\
\text { Potential }^{*}\end{array}$ \\
\hline 9212 & $\begin{array}{l}\text { 1G. Manual filling and loading SRS and/or ICPP } \\
\text { UN into safe bottles for transfer to } 9206\end{array}$ & 1970s-1989 & $\begin{array}{l}0.25 \mathrm{ppm} \mathrm{Pu} \\
0.073 \mathrm{ppm} \mathrm{Np} \\
82 \mathrm{ppm} \mathrm{Tc} \\
27.8 \%{ }^{236} \mathrm{U}\end{array}$ & Moderate \\
\hline 9212 & $1 \mathrm{H} . \quad \mathrm{ICPP} \mathrm{UO}_{3}$ received, dissolved to form UN & $1970 s-1989$ & $\begin{array}{l}0.11 \mathrm{ppb} \mathrm{Pu} \\
4.7 \mathrm{ppm} \mathrm{Np} \\
0.13 \mathrm{ppm} \mathrm{Tc} \\
10 \%{ }^{236} \mathrm{U}\end{array}$ & Moderate \\
\hline 9212 & $\begin{array}{l}\text { 11. Purification of SRS and/or ICPP UN via } \\
\text { solvent extraction (primary and secondary } \\
\text { extraction) }\end{array}$ & 1953-1970s & $\begin{array}{l}4.4 \mathrm{ppm} \mathrm{Pu} \\
5.9 \mathrm{ppm} \mathrm{Np} \\
190 \mathrm{ppm} \mathrm{Tc} \\
27.8 \%{ }^{236} \mathrm{U}\end{array}$ & Moderate \\
\hline 9212 & $\begin{array}{l}\text { 1J. Discard of solvent extraction raffinate to } \\
\text { S-3 Ponds }\end{array}$ & $\begin{array}{l}\text { 1953-mid- } \\
\text { 1980s }\end{array}$ & $\begin{array}{l}3.5 \mathrm{ppm} \mathrm{Pu} \\
5.0 \mathrm{ppm} \mathrm{Np} \\
100 \mathrm{ppm} \mathrm{Tc} \\
27.8 \%{ }^{236} \mathrm{U}\end{array}$ & Moderate \\
\hline 9212 & $1 \mathrm{~K}$. Feeding of raffinate to 9212 bioreactor & $1970 s-1989$ & $\begin{array}{l}3.5 \mathrm{ppm} \mathrm{Pu} \\
5.0 \mathrm{ppm} \mathrm{Np} \\
100 \mathrm{ppm} \mathrm{Tc} \\
27.8 \%{ }^{236} \mathrm{U}\end{array}$ & Moderate \\
\hline 9212 & $\begin{array}{l}\text { 1L. Transporting raffinate to West End Treatment } \\
\text { Facility (WETF) }\end{array}$ & $\begin{array}{l}\text { Mid-1980s- } \\
1989\end{array}$ & $\begin{array}{l}3.5 \mathrm{ppm} \mathrm{Pu} \\
5.0 \mathrm{ppm} \mathrm{Np} \\
100 \mathrm{ppm} \mathrm{Tc} \\
27.8 \%{ }^{236} \mathrm{U}\end{array}$ & Moderate \\
\hline 9212 & $\begin{array}{l}\text { 1M. Denitration of SRS and/or ICPP UNH to } \\
\mathrm{UO}_{3}\end{array}$ & 1953-1970s & $\begin{array}{l}0.5 \mathrm{ppb} \mathrm{Pu} \\
0.67 \mathrm{ppb} \mathrm{Np} \\
76 \mathrm{ppm} \mathrm{Tc} \\
27.8 \%{ }^{236} \mathrm{U}\end{array}$ & Moderate \\
\hline 9212 & $1 \mathrm{~N}$. Maintenance on denitrators or fluid beds & 1953-1970s & $\begin{array}{l}0.5 \mathrm{ppb} \mathrm{Pu} \\
0.67 \mathrm{ppb} \mathrm{Np} \\
76 \mathrm{ppm} \mathrm{Tc} \\
27.8 \%{ }^{236} \mathrm{U}\end{array}$ & Moderate \\
\hline 9212 & $\begin{array}{l}\text { 10. Conversion of SRS and/or ICPP material to } \\
\mathrm{UF}_{4} \text {, with reduction-hydrofluorination } \\
\text { performed in converted lab muffle furnaces }\end{array}$ & 1953-1970s & $\begin{array}{l}0.5 \mathrm{ppb} \mathrm{Pu} \\
0.67 \mathrm{ppb} \mathrm{Np} \\
76 \mathrm{ppm} \mathrm{Tc} \\
27.8 \%{ }^{236} \mathrm{U}\end{array}$ & Moderate \\
\hline 9212 & $\begin{array}{l}\text { 1P. Removal of dry SRS and/or ICPP } \mathrm{UF}_{4} \text { from } \\
\text { process }\end{array}$ & 1953-1970s & $\begin{array}{l}0.5 \mathrm{ppb} \mathrm{Pu} \\
0.67 \mathrm{ppb} \mathrm{Np} \\
76 \mathrm{ppm} \mathrm{Tc} \\
27.8 \%{ }^{236} \mathrm{U}\end{array}$ & Moderate \\
\hline 9212 & 1Q. Bomb reduction to metal & 1953-1970s & $\begin{array}{l}0.47 \mathrm{ppb} \mathrm{Pu} \\
0.64 \mathrm{ppb} \mathrm{Np} \\
72 \mathrm{ppm} \mathrm{Tc} \\
27.8 \%{ }^{236} \mathrm{U}\end{array}$ & Moderate \\
\hline 9212 & $\begin{array}{l}\text { 1R. Sampling, fracturing, and packaging } \\
\text { metal buttons }\end{array}$ & $1953-1989$ & $\begin{array}{l}0.47 \mathrm{ppb} \mathrm{Pu} \\
0.64 \mathrm{ppb} \mathrm{Np} \\
72 \mathrm{ppm} \mathrm{Tc} \\
27.8 \%{ }^{236} \mathrm{U}\end{array}$ & Moderate \\
\hline 9212 & 1S. SRS U-Al salvage operations & $1970 s-1989$ & $\begin{array}{l}0.13 \mathrm{ppb} \mathrm{Pu} \\
4.9 \mathrm{ppb} \mathrm{Np} \\
1.4 \mathrm{ppm} \mathrm{Tc} \\
27.8 \%{ }^{236} \mathrm{U}\end{array}$ & Moderate \\
\hline
\end{tabular}


Table 2-6 Activities at the Y-12 Complex with Potential for Worker Exposure to RU

\begin{tabular}{|c|c|c|c|c|}
\hline Location & Activity & Time Frame & Constituents & $\begin{array}{l}\text { Occupational } \\
\text { Exposure } \\
\text { Potential }^{*}\end{array}$ \\
\hline \multirow[t]{2}{*}{$9720-5$} & 1T. Metal product shipped & 1953-1990s & $\begin{array}{l}0.47 \mathrm{ppb} \mathrm{Pu} \\
0.64 \mathrm{ppb} \mathrm{Np} \\
72 \mathrm{ppm} \mathrm{Tc} \\
27.8 \%{ }^{236} \mathrm{U}\end{array}$ & No Significant \\
\hline & 2. Activities Associated with Building 9206 & & & \\
\hline 9206 & 2A. SRS UN solution "poured-up" into safe tanks & 1970s-1989 & $\begin{array}{l}0.25 \mathrm{ppm} \mathrm{Pu} \\
0.073 \mathrm{ppm} \mathrm{Np} \\
82 \mathrm{ppm} \mathrm{Tc} \\
27.8 \%{ }^{236} \mathrm{U}\end{array}$ & Moderate \\
\hline $9720-5$ & 2B. SRS U-Al ingots received & 1972-1990s & $\begin{array}{l}0.13 \mathrm{ppb} \mathrm{Pu} \\
0.49 \mathrm{ppb} \mathrm{Np} \\
1.35 \mathrm{ppm} \mathrm{Tc} \\
27.8 \%{ }^{236} \mathrm{U}\end{array}$ & No Significant \\
\hline $9720-5$ & 2C. SRS dross and sweepings received & $1972-1989$ & $\begin{array}{l}0.13 \mathrm{ppb} \mathrm{Pu} \\
0.49 \mathrm{ppb} \mathrm{Np} \\
1.35 \mathrm{ppm} \mathrm{Tc} \\
27.8 \%{ }^{236} \mathrm{U}\end{array}$ & No Significant \\
\hline 9206 & $\begin{array}{l}\text { 2D. SRS U-Al (or dross/sweepings) dissolved in } \\
\mathrm{NaOH} \text { to remove } \mathrm{Al} \text {; sodium diuranate } \\
\text { produced }\end{array}$ & $1972-1989$ & $\begin{array}{l}0.13 \mathrm{ppb} \mathrm{Pu} \\
0.49 \mathrm{ppb} \mathrm{Np} \\
1.35 \mathrm{ppm} \mathrm{Tc} \\
27.8 \%{ }^{236} \mathrm{U}\end{array}$ & Moderate \\
\hline 9206 & $\begin{array}{l}\text { 2E. SRS sodium diuranate dissolved in nitric } \\
\text { acid to produce UN }\end{array}$ & $1972-1989$ & $\begin{array}{l}0.13 \mathrm{ppb} \mathrm{Pu} \\
0.49 \mathrm{ppb} \mathrm{Np} \\
1.35 \mathrm{ppm} \mathrm{Tc} \\
27.8 \%{ }^{236} \mathrm{U}\end{array}$ & Moderate \\
\hline 9206 & 2F. ICPP $\mathrm{UO}_{3}$ received, dissolved to form UN & $\begin{array}{l}\text { 1970s-mid- } \\
\text { 1980s }\end{array}$ & $\begin{array}{l}0.11 \mathrm{ppb} \mathrm{Pu} \\
4.7 \mathrm{ppm} \mathrm{Np} \\
130 \mathrm{ppm} \mathrm{Tc} \\
10 \%{ }^{236} \mathrm{U}\end{array}$ & Moderate \\
\hline 9206 & $\begin{array}{l}\text { 2G. Purification of SRS and/or ICPP UN via } \\
\text { solvent extraction (primary and secondary } \\
\text { extraction) }\end{array}$ & 1970s-1989 & $\begin{array}{l}4.4 \mathrm{ppm} \mathrm{Pu} \\
5.9 \mathrm{ppm} \mathrm{Np} \\
190 \mathrm{ppm} \mathrm{Tc} \\
27.8 \%{ }^{236} \mathrm{U}\end{array}$ & Moderate \\
\hline 9206 & $\begin{array}{l}2 \mathrm{H} \text {. Isolating and trucking or piping raffinate to } \\
9212\end{array}$ & 1970s-1989 & $\begin{array}{l}3.5 \mathrm{ppm} \mathrm{Pu} \\
5.0 \mathrm{ppm} \mathrm{Np} \\
100 \mathrm{ppm} \mathrm{Tc} \\
27.8 \%{ }^{236} \mathrm{U}\end{array}$ & Moderate \\
\hline 9206 & 21. Denitration of SRS and/or ICPP UN to $\mathrm{UO}_{3}$ & 1970s-1989 & $\begin{array}{l}0.5 \mathrm{ppb} \mathrm{Pu} \\
0.67 \mathrm{ppb} \mathrm{Np} \\
76 \mathrm{ppm} \mathrm{Tc} \\
27.8 \%{ }^{236} \mathrm{U}\end{array}$ & Moderate \\
\hline 9206 & 2J. Maintenance on denitrators or fluid beds & 1970s-1989 & $\begin{array}{l}0.5 \mathrm{ppb} \mathrm{Pu} \\
0.67 \mathrm{ppb} \mathrm{Np} \\
76 \mathrm{ppm} \mathrm{Tc} \\
27.8 \%{ }^{236} \mathrm{U}\end{array}$ & Moderate \\
\hline 9206 & $\begin{array}{l}\text { 2K. Conversion of SRS and/or ICPP material to } \\
\mathrm{UF}_{4}\end{array}$ & 1970s-1989 & $\begin{array}{l}0.5 \mathrm{ppb} \mathrm{Pu} \\
0.67 \mathrm{ppb} \mathrm{Np} \\
76 \mathrm{ppm} \mathrm{Tc} \\
27.8 \%{ }^{236} \mathrm{U}\end{array}$ & Moderate \\
\hline 9206 & $\begin{array}{l}\text { 2L. Removal of dry SRS and/or ICPP } \mathrm{UF}_{4} \text { from } \\
\text { process }\end{array}$ & 1970s-1989 & $\begin{array}{l}0.5 \mathrm{ppb} \mathrm{Pu} \\
0.67 \mathrm{ppb} \mathrm{Np} \\
76 \mathrm{ppm} \mathrm{Tc} \\
27.8 \%{ }^{236} \mathrm{U}\end{array}$ & Moderate \\
\hline
\end{tabular}


Table 2-6 Activities at the Y-12 Complex with Potential for Worker Exposure to RU

\begin{tabular}{|c|c|c|c|c|}
\hline Location & Activity & Time Frame & Constituents & $\begin{array}{c}\text { Occupational } \\
\text { Exposure } \\
\text { Potential }^{*}\end{array}$ \\
\hline \multirow[t]{2}{*}{9206} & 2M. Bomb reduction to metal & 1970s-1989 & $\begin{array}{l}0.47 \mathrm{ppb} \mathrm{Pu} \\
0.64 \mathrm{ppb} \mathrm{Np} \\
72 \mathrm{ppm} \mathrm{Tc} \\
27.8 \%{ }^{236} \mathrm{U}\end{array}$ & Moderate \\
\hline & \multicolumn{4}{|c|}{ 3. Activities Associated with Other Uranium Handling Facilities } \\
\hline S-3 Ponds & 3A. Closure of S-3 Ponds and New Hope Pond & $\begin{array}{l}\text { 1953-mid- } \\
\text { 1980s }\end{array}$ & $\begin{array}{l}0.39 \mathrm{ppm} \mathrm{Pu} \\
0.54 \mathrm{ppm} \mathrm{Np} \\
11 \mathrm{ppm} \mathrm{Tc} \\
3.0 \%{ }^{236} \mathrm{U}\end{array}$ & Moderate \\
\hline WETF & 3B. Treatment of nitrate waste & $\begin{array}{l}\text { Mid-1980s- } \\
\text { 1990s }\end{array}$ & $\begin{array}{l}0.39 \mathrm{ppm} \mathrm{Pu} \\
0.54 \mathrm{ppm} \mathrm{Np} \\
11 \mathrm{ppm} \mathrm{Tc} \\
3.0 \%{ }^{236} \mathrm{U}\end{array}$ & Moderate \\
\hline $9720-5$ & 3C. RU materials stored & 1950s-Present & $\begin{array}{l}0.47 \mathrm{ppb} \mathrm{Pu} \\
0.64 \mathrm{ppb} \mathrm{Np} \\
72 \mathrm{ppm} \mathrm{Tc} \\
27.8 \%{ }^{236} \mathrm{U}\end{array}$ & No Significant \\
\hline \multicolumn{5}{|c|}{$\begin{array}{l}\text { * The methodology established for the DOE Mass Balance Project considered }{ }^{236} U \text { an unmonitored } \\
\text { isotope, along with Pu, Np, and Tc. In fact, }{ }^{236} U \text { is generally indistinguishable from other uranium } \\
\text { isotopes; it has the same chemical behavior and the same dose consequences as can be seen by comparing } \\
\text { uranium DAC values. Monitoring, both in the field and through bioassay, accounts for its presence and } \\
\text { correctly assigns dose or risk. Other constituents, such as plutonium, are fundamentally different in that } \\
\text { they do not have the same chemical behavior and risk. Their presence could alter the intrinsic risk of } \\
\text { handling recycled uranium. Because }{ }^{236} U \text { was monitored at the Y-12 Complex, the analysis presented in } \\
\text { this table, which used the DOE Mass Balance Project de minimis calculation methodology, estimates the } \\
\text { occupational exposure potential (the implied hazard) to be higher than it actually is. A calculation that } \\
\text { considers the non-uranium, potentially unmonitored component would at times lead to the conclusion of } \\
\text { "No Significant Occupational Exposure Potential" when }{ }^{236} U \text { is more appropriately considered. }\end{array}$} \\
\hline
\end{tabular}

Available analytical data showed that a majority of the RU constituents of concern tended to follow the HEU through the chemical processes in Buildings 9212 and 9206. Consequently, a majority of the RU constituents ended up in the HEU metal buttons shipped to SRS. Some concentration of RU constituents (relative to the uranium mass) occurred in the various solvent extraction raffinate streams. However, calculations of potential dose using the prescribed DOE methodology indicate that the fractional contribution of the RU constituents for most process streams generally was greater than $50 \%$ (with ${ }^{236} \mathrm{U}$ being the dominant constituent). Consequently, for most exposure scenarios identified in Table 2.6, a value of 3 was assigned for the constituent level (see tables in Appendix B).

The reader should note that the TRU-element and fission-product concentrations alone were not sufficiently high for any of the exposure scenarios to warrant this highest constituent rating of 3 . Instead, the assignment of a constituent level of 3 was driven largely by the high concentrations of ${ }^{236} \mathrm{U}$ in the SRS RU. This isotope is generally indistinguishable from the other isotopes of uranium. It has the same chemical behavior and the same dose consequence, as can be seen by comparing the uranium derived air concentrations (DAC) limits. For example, the DAC for Class $\mathrm{W}^{233} \mathrm{U},{ }^{234} \mathrm{U},{ }^{235} \mathrm{U},{ }^{236} \mathrm{U}$, 
and ${ }^{238} \mathrm{U}$ is the same-i.e., $3 \mathrm{E}-10$ microcuries per milliliter $(\mu \mathrm{Ci} / \mathrm{ml})$. Similarly, the dose conversion factors are also the same. Monitoring, both in the workplace and through bioassay, accounted for the presence of ${ }^{236} \mathrm{U}$ and correctly assigned dose or risk. This approach was based on two factors:

- Air sampling in the workplace was retrospective via filter collection with subsequent gross alpha counting on the filter. As such, all alphas were counted and would have included those from ${ }^{236} \mathrm{U}$. Because the DAC is the same for all uranium isotopes of concern, the need for personnel protection would have been evaluated with all radioactivity appropriately considered. The only exception would have been that the alphas counted associated with any transuranic present would have been attributed to uranium. This was considered during the development of the acceptance criteria for RU (see Section 4.3).

- In terms of bioassay monitoring, the analytical method (fluorometric procedure) measured total uranium. As a result, ${ }^{236} \mathrm{U}$ was considered in the overall dose assessment. To be conservative, the uranium result was all attributed to ${ }^{234} \mathrm{U}$, which has the highest specific activity of the uranium isotopes of concern. However, using the methodology prescribed by the DOE Project Plan, ${ }^{236} \mathrm{U}$ is included in the calculation as an additional RU constituent. Because ${ }^{236} \mathrm{U}$ was monitored and accounted for, its inclusion as a constituent distorts the implied hazard. A calculation that more appropriately treats ${ }^{236} \mathrm{U}$ in considering the non-uranium, potentially unmonitored component would at times instead lead to the conclusion of "No Significant" OEP.

In contrast to the SRS RU with high ${ }^{236} \mathrm{U}$ content, ICPP RU had an average ${ }^{236} \mathrm{U}$ content of $10 \%$. Activities involving only ICPP RU thus received a constituent level rating of 2.

Airborne potential values associated with the various exposure scenarios ranged from 0 to 3. The lowest airborne rating was assigned to HEU operations in which there was virtually no potential for direct worker contact with RU. A value of 1 was assigned to HEU operations involving direct exposure to metal or consolidated solids. A value of 2 was assigned for activities involving exposure to liquid solutions that might spray or evaporate to dryness outside the equipment. A value of 3 was assigned to operations involving direct contact with finely divided RU solids. Duration exposure values were based on actual contact time with RU as defined by DOE (see Appendix B).

Most of the potential exposure activities at the Y-12 Complex were found to have a "Moderate" OEP rating as a result of the combined product of a constituent level value of 3 for Savannah River RU or a value of 2 for Idaho RU with a value of 1 or 2 for airborne potential and exposure duration. Certain maintenance activities involving equipment that contained finely divided RU solids were assigned a value of 3 for airborne potential. However, because these types of maintenance activities were not performed very often, the overall OEP was rated "Moderate," with a cumulative score of 9.

In no instance did any identified activity involve a combination of airborne potential, constituent level, and exposure duration factors that produced an OEP score in the "High" range. Although some activities presented moderate OEP scores, the average 
DAC for the areas associated with RU was on the order of only $3 \%$ of the Plant Action Level (PAL).

The following provides information on the activities listed in Table 2.6. The numbering system used in the table (i.e., $1 \mathrm{~A}, 1 \mathrm{~B}$, etc.) is also used below.

1A. ICPP UN Solution Received in Safe Bottles: UN solution was received from ICPP in safe bottles from 1953 to the early 1970s. These solutions were weighed, sampled for U-content, uranium isotope distribution, and RU components. The uranium was removed from the UN solution by peroxide precipitation. The receiving and processing steps to establish accountability were performed in well-ventilated hoods resulting in "no significant" OEP.

1B. SRS Tanker Truck Weighed for Gross Weight: UN was received in tanker trucks $\left(3,800-5,000\right.$ gallon capacity) with ${ }^{235} \mathrm{U}$ concentration of $5 \mathrm{~g} /$ liter. The tankers were gross weighed at Building 9929-1, and the solution was transferred by pump from the tanker into a storage tank in Building 9812 in the 9212 Complex. A tare weight was obtained for the empty tanker at Building 9929-1 prior to return to SRS. This operation had "no significant" OEP.

1C. SRS Material Sampled: In Building 9812, the UN solution circulated for 3 hours and was then sampled for U-content, uranium isotope distribution, and RU components. This operation was performed with pumps and enclosed piping, resulting in "no significant" OEP.

1D. ICPP UN Solution Poured into “Pour-Up" Stations: The UN solution received in safe bottles from the ICPP was transferred at the "pour-up" station from the bottles to the storage tanks. The transfer was performed in well-ventilated hoods and was considered to have "low" OEP.

1E. SRS UN Solution Pumped to 9212: The sampled UN solution in Building 9812 was transferred by pump to the evaporator feed tanks in Building 9212. This transfer of UN solution through closed piping with an operator in attendance resulted in "no significant" OEP.

1F. SRS and/or ICPP UN Evaporated and Concentrated: UN solution received from SRS was evaporated to concentrate the uranium to approximately $150-200 \mathrm{~g} / \mathrm{liter}$. UN received from ICPP was already concentrated. This concentrated UN was relatively pure and was pumped directly to secondary extraction. The OEP for this process was considered "moderate" due to the high uranium content and worker time exposure.

\section{G. Manual Filling and Loading of SRS and/or ICPP UN into Safe Bottles for}

Transfer to 9206: The concentrated UN solution was manually drained from storage tanks into tare-weighed safe bottles, capped, gross weighed, and placed in a 6-bottle dolly for transfer to Building 9206. Prior to draining the concentrated UN into safe bottles, the UN was thoroughly mixed in the storage tanks, and samples were removed to determine uranium accountability for the transfer between Buildings 9212 and 9206 . The OEP was 
considered "moderate" due to the high uranium content in the UN and the manual handling of the safe bottles.

1H. ICPP $\mathrm{UO}_{3}$ Received, Dissolved to Form $U N: \mathrm{UO}_{3}$ received from ICPP was weighed and sampled to determine U-content, uranium isotope distribution, and RU components. The $\mathrm{UO}_{3}$ was then dissolved in $\mathrm{HNO}_{3}$ to prepare concentrated UN solution ready for secondary extraction. The $\mathrm{UO}_{3}$ was measured for accountability in a glove box. The dissolution was performed in a well-ventilated hood. These processes were considered to have "moderate" OEP.

\section{I. Purification of SRS and/or ICPP UN via Solvent Extraction: Purification of UN} from SRS and ICPP consisted of two extraction processes: primary and secondary.

The relatively pure, concentrated UN solutions from the evaporator feed tanks were first processed through secondary extraction. The organic solvent in this case was tributyl phosphate (TBP). The organic was passed counter current through the UN solution in a vertical pulsed plate column. The uranium was absorbed by the organic solvent and then removed from the solvent with demineralized water. The uranium solution was collected in storage tanks for further processing. The secondary extraction raffinate containing 2-5 wt \% uranium was recycled and became part of the feed stream for primary extraction.

The dilute uranium solutions, after filtration, evaporation, and addition of aluminum nitrate $\left[\mathrm{Al}\left(\mathrm{NO}_{3}\right)_{3}\right]$, were processed through primary extraction. The organic solvent, dibutyl carbitol, was passed counter current through the dilute uranium aqueous solution in a series of vertical columns with pulse plates. The uranium was absorbed into the organic phase. The uranium was then removed from the organic phase with dilute $\mathrm{HNO}_{3}$ and water. This was accomplished by passing the organic phase counter current to the aqueous stream in a second series of vertical columns with pulse plates. This dilute UN solution was transferred to evaporator feed tanks where it was concentrated. The primary extraction raffinate, containing approximately $1 \mathrm{ppm}$ uranium, was collected in tanker trucks and taken to Building 9818 for waste treatment.

These processes were considered to have a "moderate" OEP.

1J. Discard of Solvent Extraction Raffinate to S-3 Ponds: The primary extraction raffinate containing approximately $1 \mathrm{ppm}$ uranium was processed in Building 9818 to recover $\mathrm{Al}\left(\mathrm{NO}_{3}\right)_{3}$ for reuse. This was achieved by evaporation to a heavy sludge and the solids removed by centrifuge. The raffinate was then processed through a bioreactor before transfer to the S-3 Ponds (until their closure in 1984). Nitric acid $\left(\mathrm{HNO}_{3}\right)$ removed during the evaporation was combined with $\mathrm{HNO}_{3}$ recovered from the evaporator and other condensates generated in the chemical processes. This activity was considered "moderate" for OEP since, while the uranium content was low, some RU constituents remained.

1K. Feeding of Raffinate to 9212 Bioreactor: After the $\mathrm{Al}\left(\mathrm{NO}_{3}\right)_{3}$ was removed from the primary extraction raffinate, the raffinate was transferred into the bioreactor tank. An equal volume of calcium acetate/nutrient was added for the biological decomposition of 
the remaining $\mathrm{HNO}_{3}$. This activity was considered "moderate" for OEP since, while the uranium content was low, some RU constituents remained.

1L. Transporting Raffinate to West End Treatment Facility (WETF): After closure of the S-3 Ponds in 1984, the raffinate from the primary extraction process was transferred by tank truck to the WETF. This activity was considered "moderate" for OEP since, while the uranium content was low, some RU constituents remained.

1M. Denitration of SRS and/or ICPP UNH to $\mathrm{UO}_{3}$ : The secondary extraction product was concentrated in an evaporator to molten uranyl nitrate hexahydrate (UNH) and stored in a steam-jacketed tank to prevent solidification. Molten uranyl nitrate was conditioned by addition of 1,500 ppm sulfuric acid. This resulted in a more chemically reactive product upon conversion to $\mathrm{UO}_{3}$. Conditioned molten uranyl nitrate was denitrated by pumping the uranyl nitrate into a five-inch diameter, heated stirred-trough reactor, which produced $\mathrm{UO}_{3}$. The $\mathrm{UO}_{3}$ was in the form of freely flowing spherical particles with a predominant size range of -30 mesh to +100 mesh (U.S. sieve size). As molten uranyl nitrate was continuously pumped into the heated stirred-trough reactor, the $\mathrm{UO}_{3}$ product overflowed into a receiver tank. The OEP for this process was considered "moderate."

1N. Maintenance on Denitrators or Fluid Beds: With the exception of emergencies, maintenance was usually performed during the scheduled inventory shutdown period. Any maintenance requiring opening the denitrators or fluid beds was carefully planned to avoid potential health physics problems associated with uranium airborne exposure. This activity was considered to have "moderate" OEP.

10. Conversion of SRS and/or ICPP Material to $U_{F_{4}}$ : Uranium trioxide was converted to $\mathrm{UF}_{4}$ in a two-step fluid-bed process. First, $\mathrm{UO}_{3}$ was hydrogen-reduced to $\mathrm{UO}_{2}$ in a stainless steel fluidized-bed reactor. The $\mathrm{UO}_{2}$ was transferred to an Inconel fluidized-bed reactor and converted to $\mathrm{UF}_{4}$ with anhydrous hydrogen fluoride. Heat was supplied to both reactors by external clam-shell electrical resistance heaters. Both reactor off-gas systems contained micrometallic filters backed up in series by porous carbon filters and were equipped with gamma monitors to detect filter failure. These processes were performed in closed systems, and powder transfers were achieved via vacuum and pneumatic gas flows. The OEP was considered "moderate."

1P. Removal of Dry SRS and/or ICPP UF 4 from Process: In the early years (1953 late 1960s) before the installation of denitrators and fluid beds, the impure UN was combined with hydrogen peroxide and the resulting uranium peroxide was converted to $\mathrm{UF}_{4}$ using platinum trays and muffle furnaces. In another batch process, purified ammonium diuranate was precipitated from UN with the addition of ammonium hydroxide and converted to $\mathrm{UF}_{4}$ as described above. All of these processes were performed manually. This activity was considered to have "moderate" OEP due to its reliance on manual handling and processing. After the denitrators and fluid beds were installed, manual handling of the compounds was replaced with pneumatic transfer. 
1Q. “Bomb" Reduction to Metal: The $\mathrm{UF}_{4}$ was converted to uranium metal, referred to as "buttons" (Fig. 2.6-1), which derive their shape from the bottom of the crucible in which they solidify. The $\mathrm{UF}_{4}$ was converted to metal by "bomb" reduction through reaction with calcium at high temperature. Granular calcium metal was mixed with the $\mathrm{UF}_{4}$ and loaded into a stainless steel reactor (induction-heated furnace) fitted with a calcium fluoride liner, or crucible. $\mathrm{CaF}_{2}$ sand was used as backfill between the crucible and the reactor wall.

Along with a mixture of $\mathrm{UF}_{4}$ and calcium, the reactor was also charged with a lithium "biscuit" and an igniter capsule. While the reactive metals, lithium and calcium, will both reduce $\mathrm{UF}_{4}$, calcium served as the primary reductant for the process. Lithium was added to lower the melting point of the slag product from the reaction by taking advantage of the calcium fluoride -

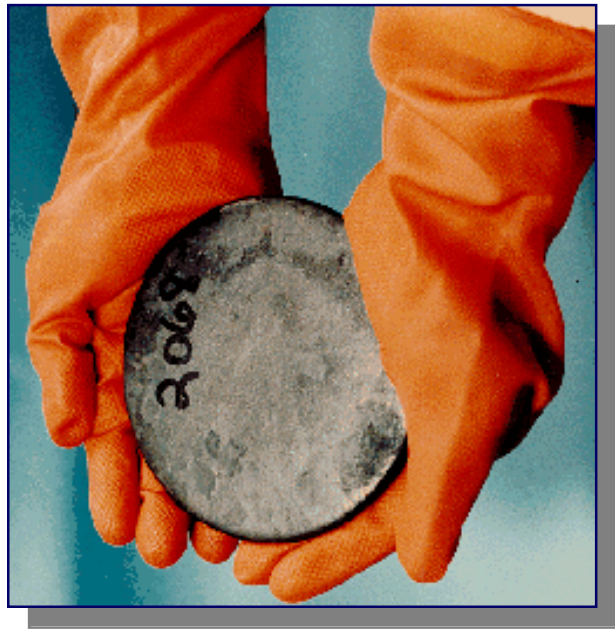

Fig. 2.6-1 Metal button. lithium fluoride eutectic. The $\mathrm{CaF}_{2}-\mathrm{LiF}$ slag produced had a lower melting point than either $\mathrm{CaF}_{2}$ or $\mathrm{LiF}$. This lower melting-point slag allowed for cleaner separation of the metal button from the slag. The igniter capsule aided initiation of the reduction reaction by providing a small exothermic reaction and associated heat spike.

This processing was performed in glove boxes and well-ventilated hoods. The OEP was considered to be "moderate."

1R. Sampling, Fracturing, and Packaging Metal Buttons: Uranium metal buttons produced were cleaned with acetic acid, dried, weighed, and transferred to Building 9212; four buttons/batch were identified with the percentage of ${ }^{235} \mathrm{U}$ of the $\mathrm{UF}_{4}$ greensalt blend. A composite sample of the four buttons was submitted to the laboratory for $U$ content, uranium isotope distribution, and 32-element specifications. If the percent ${ }^{235} \mathrm{U}$ was within $0.3 \%$ of the $\mathrm{UF}_{4}$ blend, the data was acceptable. Every tenth batch of four buttons was analyzed for RU components. Each of the four buttons was then fractured or sheared into small pieces as specified by SRS. The uranium metal pieces were packaged into DOE-approved containers and transferred to storage in Building 9720-5 to await shipment to SRS. These operations were performed inside well-ventilated hoods or glove boxes; the OEP was considered "moderate."

1S. SRS U-Al Salvage Operations: Uranium/aluminum alloy received from SRS was processed first by dissolution of the aluminum with $\mathrm{NaOH}$. The sodium diuranate solids recovered by filtration were then dissolved in $\mathrm{HNO}_{3}$. This dilute $\mathrm{UN}$ solution and the insoluble solids were sampled to establish uranium accountability. The spent $\mathrm{NaOH}$ filtrate was transferred to waste treatment. This process was transferred to Building 9206 in September 1983. This activity was performed in well-ventilated hoods. The OEP was considered "moderate." 
1T. Metal Product Shipped: Uranium metal pieces were stored in Building 9720-5 until SRS requested shipment. The metal was stored in closed containers and presented "no significant" OEP.

2A. SRS UN Solution "Poured-Up" into Safe Bottles: SRS UN solution received in safe bottles from 9212 was check weighed, and the UN was transferred to the secondary extraction feed tanks. This transfer was performed via manual pour-up or by vacuum. Although the uranium concentration of the solution was high, this transfer activity was considered to have "moderate" OEP.

2B\&C. SRS U/Al Ingots, Dross, and Sweepings Received: Beginning in late 1983, U$\mathrm{Al}$ alloy ingots, dross, and floor sweepings were received in Building 9206 for uranium recovery. Prior to this time, Building 9212 received this material. Receipt of U-Al ingots was considered to have "no significant" OEP.

2D\&E. SRS U/Al Dissolved in NaOH to Remove Al; Sodium Diuranate Dissolved: Beginning in September 1983, this process was transferred to Building 9206. Uranium/aluminum alloy received from SRS was processed first by dissolution of the aluminum with $\mathrm{NaOH}$. The sodium diuranate solids recovered by filtration were then dissolved in $\mathrm{HNO}_{3}$. This dilute $\mathrm{UN}$ solution and the insoluble solids were sampled to establish uranium accountability. These activities were performed in well-ventilated hoods. From the mid-1980s, the spent $\mathrm{NaOH}$ filtrate was transferred to waste treatment. The OEP was considered "moderate."

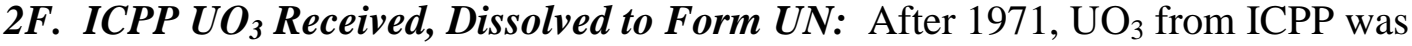
received in Building 9212, and accountability was established for U-content, uranium isotope distribution, and RU components. In the late 1970s to the late 1980s, the $\mathrm{UO}_{3}$ was processed in Building 9206. The dissolution was performed in a well-ventilated hood. These processes were considered to have "moderate" OEP.

2G. Purification of SRS and/or ICPP UN: These processes are described in activity 1I.

2H. Isolating and Trucking or Piping Raffinate to 9212: Primary extraction raffinate was collected in a tanker and trucked to Building 9818. This raffinate did not have the $\mathrm{Al}\left(\mathrm{NO}_{3}\right)_{3}$ removed. It was pumped into the bioreactor along with the 9212 primary extraction raffinate, after which the $\mathrm{Al}\left(\mathrm{NO}_{3}\right)_{3}$ was removed. This raffinate, while low in uranium content, contained RU constituents and was considered to have "moderate" OEP.

2I. Denitration of SRS and/or ICPP UNH to UO $\mathrm{O}_{3}$ : The secondary extraction product was concentrated in an evaporator to molten uranyl nitrate hexahydrate (UNH) and stored in a steam-jacketed tank to prevent solidification. Molten UNH was conditioned by addition of 1,500 ppm sulfuric acid. This resulted in a more chemically reactive product upon conversion to $\mathrm{UO}_{3}$. These processes were considered to have "moderate" OEP. 
2J. Maintenance of Denitrators and Fluid Beds: With the exception of emergencies, maintenance was usually performed during the scheduled inventory shutdown period. Any maintenance requiring opening the denitrators or fluid beds was carefully planned to avoid potential health physics problems associated with uranium airborne exposure. This activity was considered to have "moderate" OEP.

2K. Conversion of SRS and/or ICPP Material to $U_{F_{4}}$ : Uranium trioxide was converted to $\mathrm{UF}_{4}$ in a two-step fluid-bed process. First, $\mathrm{UO}_{3}$ was hydrogen-reduced to $\mathrm{UO}_{2}$ in a stainless steel reactor. The $\mathrm{UO}_{2}$ was pneumatically transferred to an Inconel reactor and hydrofluorinated to $\mathrm{UF}_{4}$ with gaseous anhydrous hydrogen fluoride. Heat was supplied to both reactors by external clam-shell electrical resistance heaters. Both reactor off-gas systems contained micrometallic filters backed up in series by porous carbon filters and were equipped with gamma monitors. The OEP was considered "moderate."

2L. Removal of Dry SRS and/or ICPP UF S $_{4} \mathrm{The}_{4} \mathrm{UF}_{4}$ produced by the two-stage fluid beds was removed from the process by pneumatic transfer to a vertical safe receiver. The $\mathrm{UF}_{4}$ was sampled for $\mathrm{U}$-content and uranium isotope distribution, and stored awaiting reduction to metal. The pneumatic transfer from the closed equipment into the glove boxes presents only "moderate" OEP.

2M. "Bomb" Reduction to Metal: The $\mathrm{UF}_{4}$ was converted to uranium metal, referred to as metal "buttons," which take their shape as they solidify from the shape of the bottom of the crucible in which they are formed. The $\mathrm{UF}_{4}$ was converted to metal by "bomb" reduction with calcium. Granular calcium metal was mixed with the $\mathrm{UF}_{4}$ and loaded into a stainless steel reactor (induction-heated furnace) fitted with a calcium fluoride liner, or crucible. $\mathrm{CaF}_{2}$ sand was used as backfill between the crucible and the reactor wall.

Along with a mixture of $\mathrm{UF}_{4}$ and calcium, the reactor was also charged with a lithium "biscuit" and an igniter capsule. While the reactive metals, lithium and calcium, both reduce $\mathrm{UF}_{4}$, calcium served as the primary reducer for the process. Lithium was added to lower the melting point of the slag product by taking advantage of the calcium fluoride lithium fluoride eutectic. The $\mathrm{CaF}_{2}-\mathrm{LiF}$ slag produced had a lower melting point than either $\mathrm{CaF}_{2}$ or $\mathrm{LiF}$. This lower melting-point slag allowed for cleaner separation between the metal product and the slag, and thereby produced a sound, smooth metal button that separated easily. The igniter capsule aided initiation of the reduction reaction by providing a small exothermic reaction and associated heat spike.

This processing was performed in closed equipment (glove boxes) and well-ventilated hoods. The OEP was considered to be "moderate."

3A. Closure of S-3 Ponds and New Hope Pond: Closure of the S-3 Ponds was accomplished by neutralizing the wastewater to precipitate the RU components and to allow denitrification prior to pumping the liquid off through an NPDES discharge point and leaving the contaminated sludge exposed. A gravel, clay, and rubber membrane and asphalt cap was placed over the ponds to complete the closure. These closure activities presented only a "moderate" OEP.

Closure of New Hope Pond was performed in a similar manner to the S-3 Pond closure, with the exception that the New Hope Pond sludge was removed before the cap 
was installed. Also, the cap construction did not include an asphalt layer. Since the pond sludge contained significantly smaller amounts of RU constituents than the S-3 Pond sludge, the OEP for the closure was less than that assigned to the S-3 Pond closure.

3B. Treatment of Nitrate Waste: Nitrate wastewasters from the UN solution evaporators and raffinates from the solvent extraction systems were periodically transported to the WETF for removal of the nitrate and final treatment prior to discharge under NPDES permit to East Fork Poplar Creek. The acid streams were first pumped into several large stirred tank reactors for batch biodenitrification. The HEU wastewaters were mixed with various aqueous waste streams containing depleted uranium generated elsewhere in the Y-12 Complex and neutralized with caustic. Carbon nutrients were subsequently added to the tanks to initiate and sustain the biological process. After biodenitrification, the resulting liquid and suspended solids were pumped to the WETF for $\mathrm{pH}$ adjustment, flocculation, and filtration. Essentially all of the process uranium (both enriched and depleted) and RU constituents were precipitated and collected with the process solids. The resulting semi-dried solids were pumped as a thick slurry to a dedicated set of large-volume tanks for long-term storage. Operators that worked around the solids collection, drying, and transport steps of the process were most likely to be exposed to the RU constituents. Because the HEU-derived streams were substantially diluted with depleted uranium from other plant operations, RU concentrations (expressed on a total uranium basis) were low. Further, the contaminated solids were not dried beyond a pumpable solid slurry and were not easily dispersed. Hence, the WETF operation was rated as having only a "moderate" OEP.

3C. $\boldsymbol{R} U$ Materials Stored: The material is stored in closed containers and so has no airborne potential, thus presenting "no significant" OEP.

\subsection{WORKER RADIOLOGICAL PROTECTION PROGRAMS}

Extensive documentation of various radiological protection programs beginning in the early 1950s was identified and reviewed by the Project Team. The documentation provides evidence of health physics programs that included personnel monitoring, urinalysis, process area monitoring and contamination control, plant site and off-site monitoring and contamination control, and special surveys. ${ }^{-}$Biannual Health Physics Progress Reports document the issuing of film hadges, finger rings, special badges, and special rings or pads, and neutron film badges. ${ }^{4}$ Beginning around 1960 and through the 1970s, the Health Physics and Industrial Hygiene Sections were organizations under the Radiation Safety Department, which was responsible for issuing the $Y$-12 Radiation

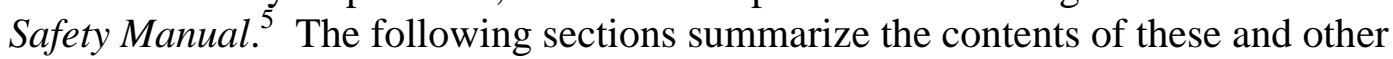
documents reviewed for this project.

\footnotetext{
${ }^{3}$ Union Carbide Nuclear Company, The Y-12 Health Physics Program, 1957.

${ }^{4}$ Carbide and Carbon Chemicals Company, Health Physics Progress Reports, 1953.

${ }^{5}$ Union Carbide Nuclear Company, Y-12 Radiation Safety Manual, 1963.
} 


\section{Roles and Responsibilities}

As stated in the 1963 Y-12 Radiation Safety Manual, responsibility for the protection of the employee against radiation health hazards rested with the line organization to the same extent that line-organization personnel were responsible for plant operation, production, and research. While the primary responsibility for implementing safety policy rested with line supervision, staff and service groups were established to provide technical assistance, to render service in the investigation and evaluation of radiation and industrial-hygiene problems, to maintain exposure records, and to give proper radiationworker training to employees.

Responsibilities of the line organization included:

- informing the Radiation Safety Department of potentially hazardous processes or materials being contemplated or used and initiating requests for protective devices or services;

- formulating, administering, and enforcing safety rules and regulations necessary to the health physics and industrial hygiene programs in all areas within the scope of their authority;

- $\quad$ planning, incorporating, and utilizing adequate health safeguards and practices in new equipment and/or procedures;

- informing all concerned employees of potential health hazards and the necessary safeguards established to guard against them;

- $\quad$ arranging for participation of employees in established personnel monitoring programs;

- maintaining material control by the proper routing, shipping, and disposal of contaminated materials in accordance with established procedures;

- determining whether company clothing would be made available and whether it was mandatory that clothing be worn for contamination or exposure control; and

- $\quad$ issuing Safety Work Permits to maintenance supervision.

The employee was expected to follow rules and regulations pertaining to job hazards for his location and assignment, monitor his person and work area as required, and notify the immediate supervisor of any known exposure to radioactive materials or conditions exceeding the allowable radiation or contamination values.

Staff Groups consisted of the Laboratory Division, Safety Department, Medical Department, and the Radiation Safety Department (which included health physics and industrial hygiene). Radiation Safety Department responsibilities included the following functional activities:

- providing line supervision with technical assistance in the establishment of suitable environmental controls, carrying out an effective environmental monitoring program for substances of concern, and recommending appropriate equipment, systems, and analytical procedures;

- continually evaluating potential personnel exposures by means of external monitoring, body fluid or excreta analyses, in vivo counting, and X-ray and clinical examinations (Medical Department), and maintaining suitable records and issuing 
reports to apprise management of existing conditions and/or immediate action requirements;

- providing technical information, assistance, and guidance to ensure conformance to then-AEC regulations and other federal and state laws pertaining to these functions, namely, employee exposure records, transportation of hazardous materials, waste disposal, release of effluents to the public domain, and exposure of the general population;

- $\quad$ auditing operations for compliance with prescribed procedures, such as (1) advising appropriate supervision of violations and, if necessary, taking immediate action through line supervision to have the operation shut down and (2) seeking improved methods of reliability as well as recommending equally safe methods of improved operating efficiency;

- conducting plant-wide meetings, preparing and issuing useful reference and training materials, assisting in emergency preparedness planning, and offering consultation on immediate problems;

- $\quad$ reviewing proposed alterations, modifications, or additions to plant facilities and equipment for compliance with pertinent plant health and safety standards;

- $\quad$ assisting investigation of conditions in work areas that may be suspected of contributing to the health problems of employees, upon the request of the Medical Department;

- $\quad$ providing special services to other departments within the plant, such as (1) sampling and analyzing potable water and sewer effluents to evaluate the control of waste discharge and to determine the possibility of potable water contamination, (2) sampling stack gases for operations supervision to determine what material is safe to be released to the atmosphere, and (3) recommending shielding requirements for the safe use of radioactive sources and X-ray units.

\section{Plant Operational Guides}

Protection guides used in administering the radiation safety and industrial hygiene programs followed those established by the Federal Radiation Council, the National Committee on Radiation Protection, the International Commission on-Radiological Protection, the American Industrial Hygiene Association, and others. ${ }^{5}$ Plant limits and guidelines included:

- Radiation Protection Guides (RPG) for exposure to external radiation (penetrating, skin, and extremities) and

- RPG for internal exposure (maximum permissible body burdens and concentration in urine for uranium, neptunium, plutonium, thorium, tritium, and other isotopes).

Personnel monitoring at the Y-12 Complex was accomplished primarily through the use of film badges and/or rings for external exposures and bioassay and in vivo counting for internal exposures. Control and action points, including additional sampling and work

\footnotetext{
${ }^{6}$ Union Carbide Nuclear Company, Y-12 Radiation Safety Manual, 1963.
} 
restrictions, were included in the RPGs and were described as follows in 1962 report documenting a review of the Y-12 Complex health protection programs.

"Actions taken at the following levels of exposure include: (1) quarterly reports to supervisors indicating the number of their people who exceed $300 \mathrm{mrem} /$ quarter penetrating radiation and 1,000 mrem/quarter non-penetrating radiation, (2) quarterly reports to supervisors naming the people who exceed 1.25 rem penetrating and those who exceed 7.5 rem non-penetrating for the quarter, (3) removal from radiation areas is recommended for those who exceed $3 \mathrm{rem} /$ quarter penetrating or $10 \mathrm{rem} /$ quarter nonpenetrating radiation. Such a restriction would be lifted only when a consecutive 4-quarter exposure drops below 5 rem penetrating or 30 rem non-penetrating; (4) removal from radiation areas is recommended for those whose average annual exposure exceeds 5 rem penetrating radiation, and they would be allowed to return only when the cumulative exposure during Y-12 Complex employment averages less than 5 rem/year for penetrating radiation, regardless of the individual's previous radiation history.

"Monitoring for internal exposure to uranium routinely involves 1,800 employees. About $10 \%$ of these are sampled weekly, $30 \%$ monthly and $60 \%$ quarterly. The criteria for action taken at various urine concentrations are detailed and well documented. Actions taken at the level of significant internal exposure are usually based on concurrent in vivo measurements, however, definite indication of a body burden by either method is sufficient to initiate investigative or restrictive action depending on the level involved. The frequency of sampling is determined semiannually based on a statistical evaluation of results from the previous six months. All urine analyses are made by the Laboratory Development Department and the results sent weekly to RSD (Radiation Safety Department). In case of an unusually high sample, RSD is notified immediately." Additional Radioactivity Concentration Guides (RCG), Plant Action Limits (PAL), and controls were established:

- concentration guides for materials in air (including uranium, neptunium, and plutonium),

- concentration guides for toxic materials in water (including uranium, neptunium, and plutonium),

- control criteria for surface contamination (including uranium, neptunium, and plutonium), and

- control criteria for shipments leaving the Y-12 Complex (including uranium and plutonium).

Workplace air analyses were performed and divided into three categories: operational and breathing zone, general air, and outside air monitoring.

Operational and breathing zone samples were taken to determine the airborne contamination generated by specific operations and/or to estimate the amount that an employee might breathe during a specific time. Health physics recommendations were made on the basis of these samples for effective personnel precautions and various

\footnotetext{
${ }^{7}$ Review of Y-12 Plant Health Protection Programs, correspondence from S. R. Sapirie, ORO Manager to Dr. C. E. Larson, Vice President, Union Carbide Nuclear Company, September 26, 1962.

${ }^{8}$ Union Carbide Nuclear Company, Y-12 Radiation Safety Manual, 1963.

${ }^{9}$ Union Carbide Nuclear Company, Y-12 Plant Quarterly Health Physics Report, September 8, 1964.
} 
administrative and mechanical controls. During the second quarter of 1964, uranium samples numbered 1,191 with an additional 1,894 samples obtained by permanently installed operational samplers for uranium analysis and 1,637 for thorium determination.

The overall exposure potential of any particular operation is not only a function of the concentration but also of the frequency and time required for the operation. The quarterly report suggests that priority be given to the jobs which have the highest product of (concentration) x (time of operation) x (frequency of operation). Weekly Air Concentration Indices (WACI) for specific operations were calculated as follows:

WACI $=$ Concentration $\left(\mathrm{dpm} / \mathrm{m}^{3}\right) \times$ length of each operation $(\mathrm{min}) \times$ (number of times operation performed per week) $x 0.00042$ (conversion factor)

The conversion factor was used to make the magnitude of the number comparable with the PAL of $70 \mathrm{dpm} / \mathrm{m}^{3}$. The WACI calculation means that performing the operation without respiratory protection is equivalent in exposure potential to breathing air for the entire work week at the concentration indicated. High-uranium air concentrations make it necessary to require the use of respiratory protective equipment in the immediate area of the operations being performed. At those times, it was recommended that respiratory protection be worn on all operations exceeding $200 \mathrm{dpm} / \mathrm{m}^{3}$. It was noted in the report that "such practice is being followed at most such locations."

General air sampling was performed to determine average airborne contamination from both uranium and thorium in several work areas of the plant. These included Metal Preparation (Buildings 9212, 9215, and 9206); Development (Buildings 9212 and 9202); Maintenance (Building 9206); Fabrication (Building 9206); and Technical Services (various buildings). At that time, the PAL for uranium was $70 \mathrm{dpm} / \mathrm{m}^{3}$ and the PAL for thorium was $4.4 \mathrm{dpm} / \mathrm{m}^{3}$. All areas during the reporting period were below the PAL, although four individual samplers in some areas averaged above the PAL for uranium.

Eleven outside air monitors, located in relation to various process buildings and prevailing winds in the Y-12 Complex area, were operated continuously. The filters were changed and analyzed biweekly for gross alpha and beta activity. All readings during the reporting period were below the PAL.

\subsection{ENVIRONMENTAL IMPACT OF RECYCLED URANIUM CONSTITUENTS}

Various sources that documented the potential environmental impact of RU components from the Y-12 Complex and the Oak Ridge Reservation were identified and reviewed by the Project Team. These reports are summarized in the following sections.

\subsubsection{Historical Radionuclide Releases from Current DOE-ORO Facilities}

An ORO report titled Historical Radionuclide Releases from Current DOE Oak Ridge Operations Office Facilities, OR-890, May 1988, documents uranium and some radionuclide releases to the air and water and burial of solid waste. This report is summarized below. 


\section{History of Airborne Emissions from the Y-12 Complex}

The major source of airborne radiological emissions from the Y-12 Complex has historically been, and continues to be, emissions of small uranium particles from metalmachining and chemical-processing operations. The primary means of controlling these emissions is the use of High Efficiency Particulate Air (HEPA) filters, baghouses, and exhaust gas scrubbers. The 13.7 curies of uranium emissions from the Y-12 Complex from 1944 to 1986 resulted primarily from major enriched uranium sources. Uranium emission information after 1954 was obtained from Y-12 Complex accountability records, the DOE Effluent Information System Radioactivity Summary Report, and the Solid Waste Information Management System. Prior to 1954, analytical and sampling techniques at the Y-12 Complex were not able to detect airborne sources of uranium, but enough data was identified in health physics reports and other sources to make some emissions estimates in the report. Since data was not available from the time period of 1948 to 1953 , emissions estimates for that time period were not made.

Uranium emissions from the Y-12 Complex were highest from 1959 through 1970. This can generally be attributed to increases in production during that time. The construction of new baghouses and other equipment at the Y-12 Complex beginning in 1969 improved the control of uranium particles and lowered overall plant emissions. From 1984 to 1986, several major enriched uranium emission control systems at the Y-12 Complex were upgraded to further reduce emissions (as part of the Production Capabilities Restoration Project). Additional reductions in emissions were achieved as the Air and Water Pollution Control Project was completed in 1988 with the installation of additional emission controls.

\section{History of Liquid Effluents from the Y-12 Complex}

Liquid effluent releases of radioactivity from the Y-12 Complex have generally been uranium solutions from the same sources that produced airborne emissions. In addition, sources of contamination, such as outside storage facilities, allowed runoff of precipitation containing uranium. Liquid wastes containing economically recoverable HEU have historically been recycled in Y-12 Complex production operations. Liquid wastes that did not contain recoverable HEU were discarded. Until the early 1980s, wastewater treatment facilities were not generally available, and so the waste was discharged into the storm sewer system and from there into East Fork Poplar Creek. Beginning in 1951 and until about 1983, some liquid wastes containing both enriched and depleted uranium were discharged into the $S-3$ Ponds located in the western end of the Y-12 Complex site. Leakage from the S-3 Pond area contributed to uranium releases into Bear Creek, as did precipitation runoff from the Bear Creek Burial Grounds (BCBG), which were used to dispose of depleted uranium solid waste.

In March 1984, when ORGDP received a permit to process Y-12 Complex aqueous waste, the discharge of process wastewater into the S-3 Ponds was discontinued. The wastewater contained in the ponds at the time of closure was treated to remove contaminants and was discharged under the Y-12 Complex NPDES permit. 


\section{History of Contaminated Solid Waste Disposal at the Y-12 Complex}

Radioactive solid wastes generated from the various Y-12 Complex production processes include uranium and uranium-contaminated materials. Uranium wastes include depleted uranium metal and oxide in the form of chips, turnings, powders, scrap, and process residues along with uranium contamination resulting from the milling and machining processes. These process residues consist of uranium-contaminated materials, such as gloves, floor sweepings, filters, and demolition debris.

Most of the solid wastes have been buried in the BCBG, while some were deposited in burial areas within the plant perimeter fence and on Chestnut Ridge. Because most of the buried uranium waste is depleted uranium metal chips, and since this metal can ignite spontaneously, the chips were placed in dumpsters that contained water to prevent spontaneous burning. The dumpsters containing both uranium and water were weighed prior to burial. Because the weight of uranium shown in disposal records is actually the total weight of the depleted uranium and the water together, the solid waste report numbers are high due to the water weight. This positive bias resulted in an error in the quantities reported in the 1985 uranium release report of approximately $1,500,000 \mathrm{~kg}$ of depleted uranium from 1947 to 1984.

\section{Summary of Radionuclides Released from the Y-12 Complex}

Uranium releases from the Y-12 Complex between 1944 and 1987 were summarized in OR-890 as follows:
- Air
$6,296 \mathrm{~kg}$
- Water
$182,374 \mathrm{~kg}$
- Burial
$17,290,523 \mathrm{~kg}$

Although the most significant releases have been uranium, the DOE report documents some release of technetium. Prior to 1972, liquid wastes containing uranium that were transferred to the S-3 Ponds were recorded as burials. Approximately 2,680 grams of technetium were received from ORGDP and directly disposed of in the ponds as contaminated aqueous waste. Other radionuclides in the waste stream associated with the processing of reactor product uranium solutions also likely went to the S-3 Ponds (although recorded as burials). Since measurements were made for contamination control purposes only, the exact quantities of material that went to the ponds are unknown. Reporting thresholds were established for these materials for accountability and security purposes. Releases to the ponds were always below these reporting thresholds.

\subsubsection{Environmental Radioactivity Levels News Releases}

Quarterly news releases on Environmental Radioactivity Levels at the Oak Ridge Gaseous Diffusion Plant from 1959 through 1964 report data gathered from air monitoring (atmospheric contamination by long-lived fission products and alpha-emitting 
materials), water monitoring, and gamma measurements. ${ }^{10}$ While these news releases were published by ORGDP, the data were gathered for the entire Oak Ridge Reservation, thus including releases from ORGDP, ORNL, and the Y-12 Complex, as well as off-site sources (e.g., Kingston Steam Plant prior to enactment of clean air legislation in the early 1970s).

\section{Air Monitoring}

Atmospheric contamination by long-lived fission products and fallout occurring in the general environment of East Tennessee were monitored by two systems of stations during this period. One system consisted of seven stations that encircled all the plant areas and provided data for evaluating the impact of all Oak Ridge Operations on the immediate environment. A second system consisted of eight stations encircling the Oak Ridge area at distances of 12 to 120 miles; after 1961, only seven stations were active.

Sampling was accomplished by passing air continuously through filter paper. The data collected were accumulated and tabulated in average $\mu \mathrm{Ci} / \mathrm{cc}$ of air sampled. Figures 2.8-1 and 2.8-2 show the locations of both the perimeter and remote continuous air monitoring stations. Summaries of the data for the perimeter and remote stations are shown in Tables 2.8-1 and 2.8-2.

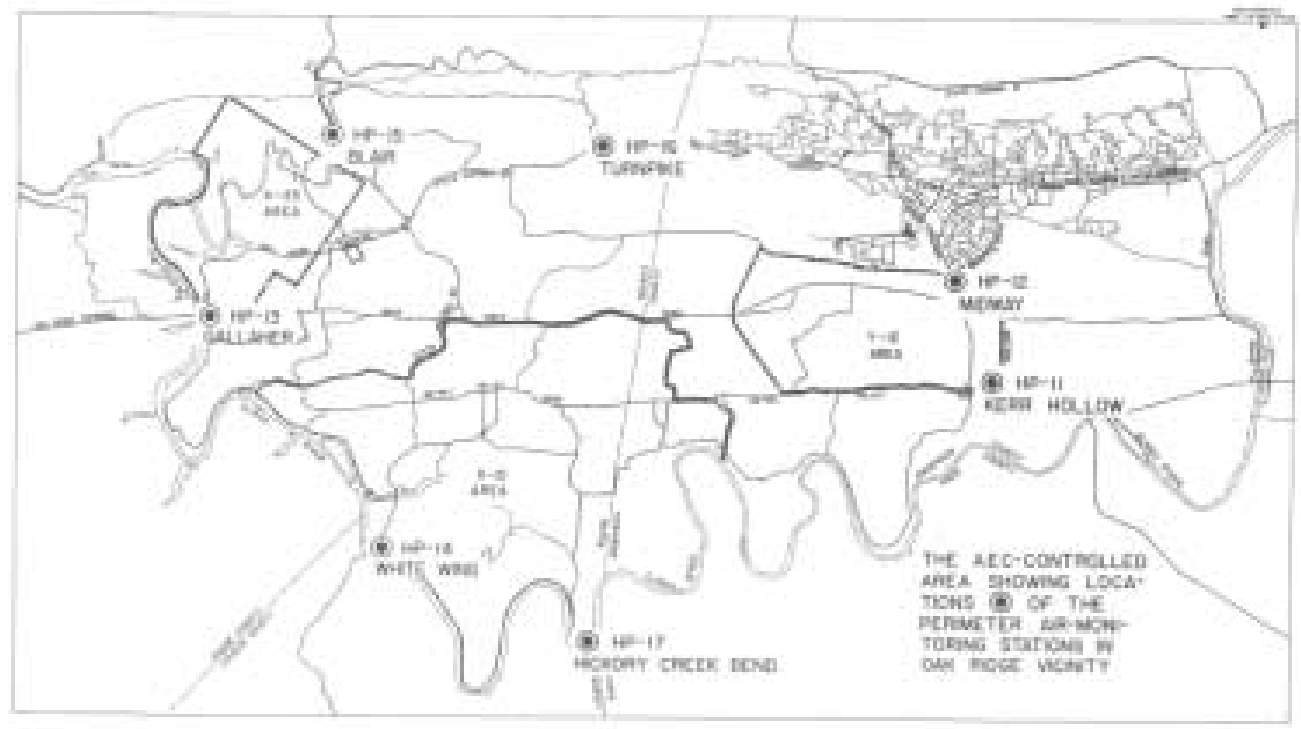

Fig. 2.8-1 Continuous Air Monitoring Data - Perimeter Stations.

\footnotetext{
${ }^{10}$ News Releases, Environmental Radioactivity Levels, the Oak Ridge Gaseous Diffusion Plant, ORGDP, January 1959 through June 1964.

${ }^{11}$ The Berea, Kentucky, remote station provided no samples after 1961.
} 


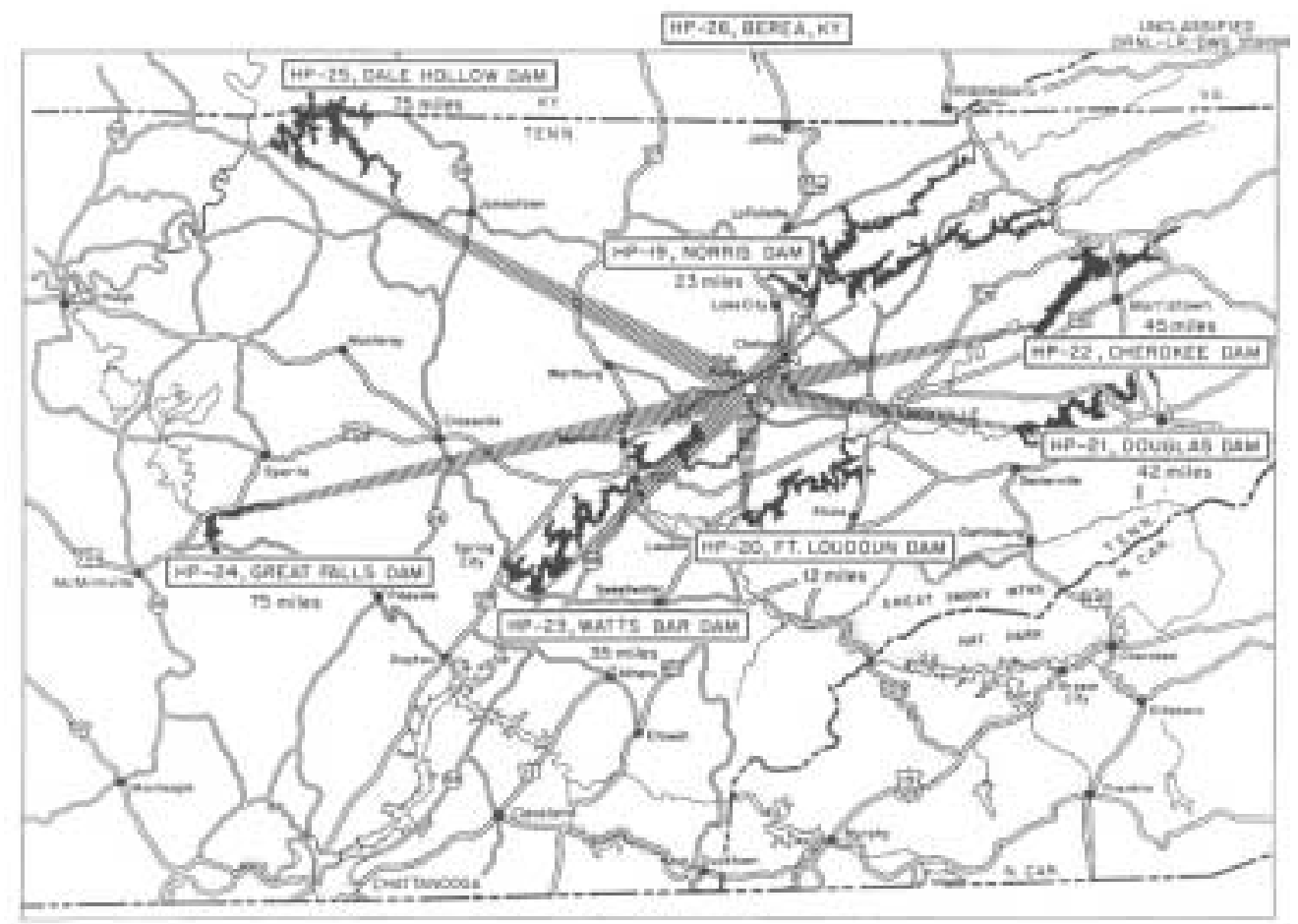

Fig. 2.8-2 Continuous Air Monitoring Data - Remote Stations.

Table 2.8-1 Continuous Air Monitoring Data - Perimeter Stations Long-Lived Gross Beta Activity of Particulates in Air

\begin{tabular}{|c|c|c|c|c|c|c|}
\hline Year & Period & $\begin{array}{c}\text { \# samples } \\
\text { (range) }\end{array}$ & Max & Min* & Average* of $^{\star} \mathbf{M P}^{\dagger}$ \\
\hline 1959 & annual & $49-52$ & 81.31 & 0.08 & 15.76 & 1.60 \\
\hline 1960 & Q1 & 13 & 2.99 & 0.24 & 1.08 & 0.11 \\
\hline 1960 & Q2 & 13 & 4.22 & 0.21 & 1.63 & 0.16 \\
\hline 1960 & Q3 & 14 & 2.86 & 0.07 & 0.85 & 0.09 \\
\hline 1960 & Q4 & 13 & 1.80 & 0.04 & 0.46 & 0.05 \\
\hline 1961 & Q1 & $13-14$ & 1.65 & 0.00 & 0.60 & 0.06 \\
\hline 1961 & Q2 & $13-14$ & 8.51 & 0.18 & 1.19 & 0.12 \\
\hline 1961 & Q3 & 14 & 157.00 & 0.07 & 20.90 & 2.10 \\
\hline 1961 & Q4 & 13 & 73.00 & 16.00 & 35.00 & 3.50 \\
\hline 1962 & Q1/Q2 & $26-74$ & 90.00 & 22.00 & 41.00 & 4.10 \\
\hline 1962 & Q3/Q4 & $26-74$ & 81.00 & 11.00 & 30.00 & 3.00 \\
\hline 1963 & Q1/Q2 & $26-181$ & 131.00 & 27.00 & 60.00 & 6.00 \\
\hline 1963 & Q3/Q4 & $26-180$ & 69.00 & 3.00 & 20.00 & 2.00 \\
\hline 1964 & Q1/Q2 & $26-180$ & 35.00 & 4.00 & 13.00 & 1.30 \\
\hline
\end{tabular}

* Units of $10^{-13} \mu \mathrm{Ci} / \mathrm{cc}$.

${ }^{\dagger}$ Maximum Permissible Concentration (MPC) is taken to be $10^{-10} \mu \mathrm{Ci} /$ cc as recommended in NBS Handbook 69. 
The highest percent MPC values for the perimeter and remote monitoring stations for the period were in the first half of 1963 and were reported as 6\% and 6.3\%, respectively. The news release for that period states, "Although these values are approximately two times greater than the average for the last half of 1962, they are no greater than the average of those measured in other areas of the United States and reported by the U.S. Public Health Radiation Surveillance Network for the period January through May, 1963."

Table 2.8-2 Continuous Air Monitoring Data - Remote Stations Long-Lived Gross Beta Activity of Particulates in Air

\begin{tabular}{|c|c|c|c|c|c|c|}
\hline Year & Period & $\begin{array}{c}\text { \# samples } \\
\text { (range) }\end{array}$ & $\operatorname{Max}^{*}$ & Min* & Average* $^{*}$ & $\%$ of $\mathrm{MPC}^{\dagger}$ \\
\hline 1959 & annual & $26-52$ & 100.52 & 0.14 & 13.97 & 1.40 \\
\hline 1960 & Q1 & 13 & 2.73 & 0.12 & 1.14 & 0.11 \\
\hline 1960 & Q2 & $10-13$ & 3.11 & 0.08 & 1.65 & 0.17 \\
\hline 1960 & Q3 & $11-13$ & 2.39 & 0.16 & 0.80 & 0.08 \\
\hline 1960 & Q4 & $12-13$ & 2.66 & 0.12 & 0.49 & 0.05 \\
\hline 1961 & Q1 & $13-14$ & 1.18 & 0.00 & 0.55 & 0.06 \\
\hline 1961 & Q2 & $13-14$ & 2.22 & 0.20 & 0.95 & 0.10 \\
\hline 1961 & Q3 & 14 & 220.00 & 0.07 & 23.60 & 2.40 \\
\hline 1961 & Q4 & 13 & 88.00 & 15.00 & 41.00 & 4.10 \\
\hline 1962 & Q1/Q2 & 26 & 97.00 & 20.00 & 49.00 & 4.90 \\
\hline 1962 & Q3/Q4 & 26 & 159.00 & 11.00 & 36.00 & 3.60 \\
\hline 1963 & Q1/Q2 & $25-26$ & 114.00 & 35.00 & 63.00 & 6.30 \\
\hline 1963 & Q3/Q4 & $25-26$ & 91.00 & 4.00 & 24.00 & 2.40 \\
\hline 1964 & Q1/Q2 & $25-26$ & 48.00 & 4.00 & 17.00 & 1.70 \\
\hline
\end{tabular}

* Units of $10^{-13} \mu \mathrm{Ci} / \mathrm{cc}$.

${ }^{\dagger}$ Maximum Permissible Concentration (MPC) is taken to be $10^{-10} \mu \mathrm{Ci} /$ cc as recommended in NBS Handbook 69.

\section{Water Monitoring}

Liquid wastes originating at ORGDP and the Y-12 Complex were discharged to East Fork Poplar Creek which flows into the Clinch River (ORNL discharged aqueous waste to the Clinch River upstream of ORGDP). River monitoring was performed so that the resulting average concentrations in the Clinch River from all Oak Ridge DOE operations complied with the maximum permissible levels for populations adjacent to DOE (then, AEC) facilities as recommended by the National Committee on Radiation Protection 
(NCRP). Radioactive liquid wastes were sampled at a number of locations in the Clinch River, beginning at a point of entry of wastes into the river (mile 20.8) and ending at Center's Ferry near Kingston, Tennessee (mile 4.5). The average concentration of radioactivity at these two points was then calculated. The average concentration of transuranic alpha emitters at mile 20.8 was also calculated. Stream gauging operations were carried on continuously by the U.S. Geological Survey to obtain dilution factors for calculating the probable concentrations of wastes in the river. The average activity in East Fork Poplar Creek was also reported in 1959 and 1960. The results for the five-year period are shown in Table 2.8-3 as percentages of the $\mathrm{MPC}_{\mathrm{W}}$ for populations in the neighborhood of a controlled area.

Table 2.8-3 ORGDP Water Monitoring Data

\begin{tabular}{|c|c|c|c|c|c|}
\hline Year & Period & \multicolumn{2}{|c|}{$\%$ MPC (Clinch River) $^{\star}$} & $\begin{array}{c}\% \text { MPC TRU } \\
\text { alpha emitters }\end{array}$ & $\begin{array}{c}\% \text { MPC } \\
\text { activity } \\
\text { (Clinch River) }\end{array}$ \\
\hline 1959 & Mear & 25.4 & 22.3 & 0.0300 & 0.03 \\
\hline 1960 & Q1 & 26.9 & 16.4 & 0.0020 & 0.02 \\
\hline 1960 & Q2 & 23.2 & 7.9 & 0.0010 & 0.03 \\
\hline 1960 & Q3 & 12.6 & 4.9 & 0.0010 & 0.04 \\
\hline 1960 & Q4 & 22.0 & 17.0 & 0.0004 & \\
\hline 1961 & Q1 & 33.0 & 13.0 & 0.0007 & \\
\hline 1961 & Q2 & 21.0 & 7.0 & 0.0005 & \\
\hline 1961 & Q3 & 6.3 & 3.1 & 0.0030 & \\
\hline 1961 & Q4 & 8.8 & 5.5 & 0.0001 & \\
\hline 1962 & Q1/Q2 & 8.2 & 6.2 & 0.0002 & \\
\hline 1962 & Q3/Q4 & 6.4 & 3.9 & 0.0003 & \\
\hline 1963 & Q1/Q2 & 5.6 & 3.4 & 0.0002 & \\
\hline 1963 & Q3/Q4 & 3.3 & 4.0 & 0.0002 & \\
\hline 1964 & Q1/Q2 & 3.5 & 2.0 & $<0.0010$ & \\
\hline
\end{tabular}

*The fraction of the total beta activity comprised by each isotope was determined from analysis of longlived radionuclides contained in the effluent, and a weighted average maximum permissible concentration for water $\left(M P C_{W)}\right.$ for the mixture of radionuclides was calculated on the basis of the isotopic distribution using the MPC values of each isotope as recommended by the NCRP. The average concentration of gross beta activity in the Clinch River was compared to the calculated $M P C_{W}$ values. The concentration of uranium was compared with the specific $M P C_{W}$ value for uranium.

There were no instances of water release above the long-term MPC.

\section{Gamma Measurements}

External gamma radiation levels were measured monthly at a number of locations in the Oak Ridge area. These locations included Solway Gate, Y-12 East Portal, Newcombe Road in Oak Ridge, Gallaher Gate, and White Wing Gate. Measurements were taken 
with a Gieger-Muller tube at a distance of three feet above ground, with the results tabulated in $\mathrm{mR} / \mathrm{hr}$. These results are shown in Table 2.8-4.

The news releases state, "These average levels were the same as average background levels obtained throughout the United States by the U.S. Public Health Service Radiation Surveillance Network, employing similar methods and detection instruments."

Table 2.8-4 External Gamma Radiation Levels (mR/hr)

\begin{tabular}{|c|c|c|}
\hline Year & Period & Average \\
\hline 1959 & year & 0.024 \\
\hline 1960 & Q1 & 0.017 \\
\hline 1960 & Q2 & 0.020 \\
\hline 1960 & Q3 & 0.020 \\
\hline 1960 & Q4 & 0.020 \\
\hline 1961 & Q1 & 0.015 \\
\hline 1961 & Q2 & 0.020 \\
\hline 1961 & Q3 & 0.019 \\
\hline 1961 & Q4 & 0.020 \\
\hline 1962 & Q1/Q2 & 0.027 \\
\hline 1962 & Q3/Q4 & 0.031 \\
\hline 1963 & Q1/Q2 & 0.028 \\
\hline 1963 & Q3/Q4 & 0.023 \\
\hline 1964 & Q1/Q2 & 0.014 \\
\hline
\end{tabular}

\subsubsection{DOE Joint Task Force on Uranium Recycle Materials Processing}

A joint task force was assembled by the Department of Energy in 1985 to study past and current practices relating to the processing of uranium recycle materials. From the data reviewed, the task force did not disclose any instance in which the environment, safety, or health of plant workers or the public were jeopardized or compromised. The primary recommendation for all DOE sites from this study was to develop formal, mutually agreeable shipper/receiver specifications on maximum permissible levels of constituents in recycled uranium materials. No specific recommendations were suggested regarding the releases from the Y-12 Complex. This study is documented in DOE/OR-859, Report of the Joint Task Force on Uranium Recycle Materials Processing, issued in September 1985. 


\subsubsection{Oak Ridge Dose Reconstruction Project}

An Oak Ridge Dose Reconstruction Project was initiated in 1994 as follow-up to the Oak Ridge Dose Reconstruction Feasibility Study, which recommended a closer examination of past uranium emissions and potential resulting exposures. The initial feasibility study performed screening calculations to identify those operations and materials that warranted detailed investigation in terms of potential off-site exposures to the individuals that have lived in the areas surrounding ORR. At the close of the feasibility study, the Tennessee Department of Health and the Oak Ridge Health Agreement Steering Panel (ORHASP) recommended that a detailed project including dose reconstruction be performed. The results of a portion of this project were documented in the July-1999 Task 6 report titled Uranium Releases from the Oak Ridge Reservation - A Review of the Quality of Historical Efflyent Monitoring Data and a Screening Evaluation of Potential Off-Site Exposures. 12

The Task 6 component of the project involved further evaluation of Oak Ridge uranium operations and effluent monitoring records to determine if uranium releases from ORR (including the cumulative effects of releases from all DOE-ORR facilities) likely resulted in off-site doses that warranted further study. The team performed a historical review of air and water release data, including health physics and industrial hygiene reports, stack monitoring data, accident and investigation reports, logbooks, and procedures for the period 1944 through 1988.

Estimates of uranium releases for individual exhaust stacks and building vents were tabulated by the Project Team from original Y-12 Complex documents and included two basic types of release information: (1) reported releases for individual buildings or uranium processes and (2) exhaust stack or indoor air monitoring data and quantities of air exhausted from individual buildings or exhaust stacks. For unmonitored releases or for sampling periods where there was limited data, the Project Team used uranium production rates or release estimates for preceding or subsequent years for which sampling data were available.

For operating periods for which monitoring data were available, the Project Team used uranium concentrations determined from air samples in combination with the amount of air exhausted through stacks and building vents to estimate the quantity of uranium routinely or accidentally released during a particular sampling period.

The Task 6 team concluded that estimates of uranium releases were underestimated by the AEC, DOE, and ORR site contractors. Based on discussion with Y-12 Complex workers, unmonitored release sources were almost exclusively associated with depleted uranium operations and would account for the majority of the differences between the Task 6 and DOE release estimates. $\frac{13}{}$ These estimates are shown in Table 2.8-5.

The screening evaluation of potential off-site exposure to waterborne uranium was based on environmental measurements of uranium in local surface waters. Reported annual average uranium concentrations in the Clinch River were used for the Task 6 screening evaluation. These values were based on water samples collected at the confluence of Poplar Creek and the Clinch River for all the years of operation up to 1995.

12 Buddenbaum et al., Uranium Releases from the Oak Ridge Reservation- A Review of the Quality of Historical Effluent Monitoring Data and a Screening Evaluation of Potential Off-Site Exposures, 1999.

${ }^{13}$ Personal communication between Edward Owings (former Y-12 worker) and the Task 6 team, July 1997. 
Table 2.8-5 Y-12 Complex Airborne Uranium Release Estimates

\begin{tabular}{|c|c|c|c|c|c|}
\hline Year & $\begin{array}{c}\text { Task } 6 \\
\text { Estimate }(\mathbf{k g})\end{array}$ & $\begin{array}{c}\text { DOE } \\
\text { Estimate (kg) }\end{array}$ & Year & $\begin{array}{c}\text { Task } 6 \\
\text { Estimate }(\mathrm{kg})\end{array}$ & $\begin{array}{c}\text { DOE } \\
\text { Estimate }(\mathrm{kg})\end{array}$ \\
\hline 1944 & 310 & 55 & 1970 & 300 & 259 \\
\hline 1945 & 670 & 102 & 1971 & 580 & 290 \\
\hline 1946 & 390 & 102 & 1972 & 870 & 222 \\
\hline 1947 & 250 & 55 & 1973 & 410 & 206 \\
\hline 1948 & 650 & 0 & 1974 & 210 & 207 \\
\hline 1949 & 650 & 0 & 1975 & 210 & 209 \\
\hline 1950 & 650 & 0 & 1976 & 210 & 207 \\
\hline 1951 & 650 & 0 & 1977 & 210 & 206 \\
\hline 1952 & 650 & 0 & 1978 & 210 & 205 \\
\hline 1953 & 4000 & 30 & 1979 & 210 & 206 \\
\hline 1954 & 3800 & 32 & 1980 & 220 & 218 \\
\hline 1955 & 3800 & 32 & 1981 & 210 & 207 \\
\hline 1956 & 3000 & 43 & 1982 & 210 & 207 \\
\hline 1957 & 2300 & 41 & 1983 & 210 & 208 \\
\hline 1958 & 5700 & 41 & 1984 & 330 & 329 \\
\hline 1959 & 6200 & 120 & 1985 & 210 & 210 \\
\hline 1960 & 930 & 99 & 1986 & 210 & 211 \\
\hline 1961 & 1300 & 109 & 1987 & 150 & 116 \\
\hline 1962 & 1400 & 100 & 1988 & 150 & 116 \\
\hline 1963 & 2100 & 103 & $1989^{*}$ & & 44 \\
\hline 1964 & 2700 & 170 & $1990^{*}$ & & 21 \\
\hline 1965 & 640 & 281 & $1991^{*}$ & & 21 \\
\hline 1966 & 920 & 212 & $1992^{*}$ & & 7 \\
\hline 1967 & 340 & 212 & $1993^{*}$ & & 3 \\
\hline 1968 & 440 & 211 & $1994^{*}$ & & 24 \\
\hline 1969 & 250 & 223 & $1995^{*}$ & & 2 \\
\hline & & & TOTAL & 50,000 & 6,535 \\
\hline
\end{tabular}

* Values for these years were based on releases reported by DOE. Release estimates for these late years were not independently reconstructed by the Project Team.

Source: DOE Estimates for years 1944 to 1988 compiled from USDOE 1988; estimates for years 1989 to 1995 were from LMES 1996. Task 6 estimates are rounded to two significant figures. 
Effluent monitoring data were also evaluated for quality and consistency with previous DOE historical uranium release reports. The average annual concentration of uranium in the Clinch River for the period 1944 to 1995 was estimated to be $0.015 \mathrm{mgL}^{-1}$.

Based on the decision guidelines from the ORHASP, the Task 6 team concluded that the Y-12 Complex uranium releases are candidates for further study, but that they are not high-priority candidates.

The Task 7 component of the Oak Ridge Dose Reconstruction effort involved the screening of additional potential materials of concern, including neptunium and technetium. This portion of the effort was documented in the July-1999 Task 7 report. ${ }^{14}$

\section{Neptunium}

No historical stack monitoring or ambient air monitoring data for $\mathrm{Np}$ were identified by the Task 7 team. Therefore, Np sources were estimated based on the total amount of recycled uranium received at the Y-12 Complex from ICPP and SRS for each year from 1953 to 1984.15 These receipts are shown in Table 2.8-6.

$\mathrm{Np}$ concentrations were calculated based on the upper alpha activity of 200,000 $\mathrm{dpm} \mathrm{g}^{-1}$ of uranium. ${ }^{16} \mathrm{~Np}$ releases to air from the Y-12 Complex were estimated by calculating a release fraction from the inventory differences for natural uranium reported

by Owings. ${ }^{17}$ The calculated natural uranium release fraction based on inventory differences was $0.1 \%$. Because the inventory difference value does not distinguish between releases to either air or water, the Project Team relied on its knowledge of uranium processing at the $\mathrm{Y}-12$ Complex to estimate the fraction of the inventory difference that might have been released to air and water. In this analysis, it was assumed that one quarter of the $0.1 \%$ inventory difference was released to the air, while three quarters was released to water. The estimated release fraction to air $(0.025 \%)$ was then multiplied by the Y-12 Complex Np activity inventories to estimate yearly release to air. Similarly, the estimated release fraction to water $(0.075 \%)$ was multiplied by the Y-12 Complex Np activity inventories to estimate the yearly releases to water. Table 2.87 provides the estimated airborne and water releases of $\mathrm{Np}$ per year from the Y-12 Complex for the period 1953 to 1995.

\section{Technetium}

No airborne effluent information for the Y-12 Complex was located by the Task 7 team. The basis for the estimate of airborne Tc from the plant was, again, the total amount of recycled uranium received from ICPP and SRS between 1953 and 1984 (see Table 2.8-6). The yearly masses of uranium received were multiplied by the estimated Tc concentration in the recycled uranium to arrive at an estimate of the total Tc activityat the Y-12 Complex. Based on information in the ORGDP mass balance document, 18 the team assumed a Tc concentration of $7 \mathrm{ppm}$ in the recycled uranium. The material

\footnotetext{
${ }^{14}$ Bruce, Screening-Level Evaluation of Additional Potential Materials of Concern, 1999.

${ }^{15}$ Egli et al., The Report of the Joint Task Force on Uranium Recycle Materials Processing, 1985.

${ }^{16}$ Ibid.

${ }^{17}$ Owings, E., Historical Review of Accountable Nuclear Materials at the Y-12 Plant, 1995.

${ }^{18}$ Oak Ridge Gaseous Diffusion Plant, Draft Mass Balance, ORGDP, 1978.
} 
Table 2.8-6 Reported Y-12 Complex Receipts of Recycled Uranium

\begin{tabular}{|c|c|c|c|}
\hline Year & SRP (kg U) & ICPP (kg U) & Total (kg U) \\
\hline 1953 & 0 & 101 & 101 \\
\hline 1954 & 0 & 217 & 217 \\
\hline 1955 & 3 & 828 & 831 \\
\hline 1956 & 0 & 744 & 744 \\
\hline 1957 & 201 & 797 & 998 \\
\hline 1958 & 258 & 898 & 1,156 \\
\hline 1959 & 270 & 3,741 & 4,011 \\
\hline 1960 & 6,395 & 769 & 7,164 \\
\hline 1961 & 2,305 & 0 & 2,305 \\
\hline 1962 & 2,701 & 775 & 3,476 \\
\hline 1963 & 6,461 & 0 & 6,461 \\
\hline 1964 & 2,977 & 771 & 3,748 \\
\hline 1965 & 3,546 & 425 & 3,971 \\
\hline 1966 & 3,467 & 1,408 & 4,875 \\
\hline 1967 & 2,604 & 0 & 2,604 \\
\hline 1968 & 2,097 & 394 & 2,491 \\
\hline 1969 & 4,121 & 427 & 4,548 \\
\hline 1970 & 2,045 & 108 & 2,153 \\
\hline 1971 & 3,805 & 1,660 & 5,465 \\
\hline 1972 & 4,716 & 415 & 5,131 \\
\hline 1973 & 5,051 & 563 & 5,614 \\
\hline 1974 & 4,599 & 0 & 4,599 \\
\hline 1975 & 5,110 & 1,702 & 6,812 \\
\hline 1976 & 4,320 & 195 & 4,515 \\
\hline 1977 & 4,497 & 1,333 & 5,830 \\
\hline 1978 & 2,070 & 525 & 2,595 \\
\hline 1979 & 4,591 & 535 & 5,126 \\
\hline 1980 & 1,510 & 0 & 1,510 \\
\hline 1981 & 4,918 & 905 & 5,823 \\
\hline 1982 & 5,728 & 577 & 6,305 \\
\hline 1983 & 6,682 & 1,041 & 7,723 \\
\hline 1984 & 5,776 & 2,868 & 8,644 \\
\hline TOTAL & 102,824 & 24,722 & 127,546 \\
\hline
\end{tabular}

Note: Historical data from Egli et al., The Report of the Joint Task Force on Uranium Recycle Materials

Processing, 1985; does not necessarily agree with the findings of this study as given in Table 3.2-1. 
Table 2.8-7 Estimated Y-12 Complex Np Releases

\begin{tabular}{|c|c|c|}
\hline Year & Air Release $(\mu \mathrm{Ci})$ & Water Release $(\mu \mathrm{Ci})$ \\
\hline 1953 & 2.3 & 6.8 \\
\hline 1954 & 4.9 & 15 \\
\hline 1955 & 19 & 56 \\
\hline 1956 & 17 & 50 \\
\hline 1957 & 22 & 67 \\
\hline 1958 & 26 & 78 \\
\hline 1959 & 90 & 270 \\
\hline 1960 & 160 & 480 \\
\hline 1961 & 52 & 160 \\
\hline 1962 & 78 & 230 \\
\hline 1963 & 150 & 440 \\
\hline 1964 & 84 & 250 \\
\hline 1965 & 89 & 270 \\
\hline 1966 & 110 & 330 \\
\hline 1967 & 59 & 180 \\
\hline 1968 & 56 & 170 \\
\hline 1969 & 100 & 310 \\
\hline 1970 & 48 & 150 \\
\hline 1971 & 120 & 370 \\
\hline 1972 & 120 & 350 \\
\hline 1973 & 130 & 380 \\
\hline 1974 & 100 & 310 \\
\hline 1975 & 150 & 460 \\
\hline 1976 & 100 & 310 \\
\hline 1977 & 130 & 390 \\
\hline 1978 & 58 & 180 \\
\hline 1979 & 120 & 350 \\
\hline 1980 & 34 & 100 \\
\hline 1981 & 130 & 390 \\
\hline 1982 & 140 & 430 \\
\hline 1983 & 170 & 520 \\
\hline 1984 & 190 & 580 \\
\hline 1985 & 10 & 100 \\
\hline 1986 & 10 & 100 \\
\hline 1987 & 10 & 100 \\
\hline 1988 & 10 & 100 \\
\hline 1989 & 10 & 100 \\
\hline 1990 & 10 & 100 \\
\hline 1991 & 10 & 100 \\
\hline 1992 & 10 & 100 \\
\hline 1993 & 10 & 100 \\
\hline 1994 & 10 & 100 \\
\hline 1995 & 10 & 100 \\
\hline Total $(\mu \mathrm{Ci})$ & $2,969.2$ & $9,732.8$ \\
\hline
\end{tabular}


balance document states that Paducah personnel estimated government reactor recycled uranium at $7 \mathrm{ppm} \mathrm{Tc}$ and that this estimate is consistent with ORGDP data. The mass of Tc received was then calculated using the following equation:

$$
T c(m g)=U(k g) x T c \text { concentration }\left(\mathrm{mg} \mathrm{kg}^{-1}\right)
$$

The mass of Tc received in the recycled uranium in 1953 would then be the following:

$$
T c(m g)=101 \mathrm{~kg}^{2} 7 \mathrm{mg} \mathrm{kg}^{-1}=707 \mathrm{mg} \mathrm{Tc}
$$

The activity of Tc received was calculated by multiplying the mass of Tc by the specific activity of $\mathrm{Tc}\left(1.7 \times 10^{-2} \mathrm{Ci} \mathrm{g}^{-1}\right)$ :

$$
T c(C i)=(0.707 g \mathrm{Tc}) \times\left(1.7 \times 10^{-2} \mathrm{Cig}^{-1}\right)=0.012 \mathrm{Ci}
$$

The next step in determining the Tc source term was to define the amount of Tc released to the air. This was accomplished by calculating a release fraction based on the inventory differences for natural uranium at the Y-12 Complex reported by Owings. 19 Inventory difference values were once termed "material unaccounted for" (MUF). The calculated natural uranium release fraction based on inventory differences was $0.1 \%$. This value was multiplied by the Y-12 Complex Tc activity inventories to yield conservative annual airborne release estimates. The results of this analysis are presented in Table 2.8-8.

No measurements of Tc concentrations in liquid effluent from the plant prior to the late 1980s were identified by the Project Team. Beginning in 1991, concentrations of Tc were measured monthly in East Fork Poplar Creek at the junction of Bear Creek and Scarboro Roads. The concentrations ranged from less than background to $160 \mathrm{pCiL}^{-1}$. Individual sample results were not located.

In addition to routine monitoring, two special studies also measured Tc concentrations in surface waters around the ORR. The potential source of these Tc concentrations was not limited to the Y-12 Complex.

- The Instream Contaminant Study - the only surface water sample analyzed for Tc as part of this study was located in Watts Bar Reservoicat Clinch River Mile 6.8. The concentration of $\mathrm{Tc}$ in this sample was $0.73 \mathrm{pCiL}^{-1}$. 20

- The Clinch River Remedial Investigation - Tc concentrations in the Clinch River ranged from less than the limit of detection to $23 \mathrm{pCiL}^{-1}$. The Poplar Creek concentrations ranged from less than the limit of detection to $32 \mathrm{pCiL}^{-1}$.

\footnotetext{
${ }^{19}$ Owings, Historical Review of Accountable Nuclear Materials at the Y-12 Plant, 1995.

${ }^{20}$ Tennessee Valley Authority, Instream Contaminant Study, 1985.

${ }^{21}$ Cook et al., Phase I Data Summary Report for the Clinch River Remedial Investigation, 1992.
} 
Table 2.8-8 Estimated Tc Releases from the Y-12 Complex

\begin{tabular}{|c|c|}
\hline Year & Estimated Tc Release (Ci) \\
\hline 1953 & $1.2 \times 10^{-5}$ \\
\hline 1954 & $2.6 \times 10^{-5}$ \\
\hline 1955 & $9.9 \times 10^{-5}$ \\
\hline 1956 & $8.9 \times 10^{-5}$ \\
\hline 1957 & $1.2 \times 10^{-4}$ \\
\hline 1958 & $1.4 \times 10^{-4}$ \\
\hline 1959 & $4.8 \times 10^{-4}$ \\
\hline 1960 & $8.5 \times 10^{-4}$ \\
\hline 1961 & $2.7 \times 10^{-4}$ \\
\hline 1962 & $4.1 \times 10^{-4}$ \\
\hline 1963 & $7.7 \times 10^{-4}$ \\
\hline 1964 & $4.5 \times 10^{-4}$ \\
\hline 1965 & $4.7 \times 10^{-4}$ \\
\hline 1966 & $5.8 \times 10^{-4}$ \\
\hline 1967 & $3.1 \times 10^{-4}$ \\
\hline 1968 & $3.0 \times 10^{-4}$ \\
\hline 1969 & $5.4 \times 10^{-4}$ \\
\hline 1970 & $2.6 \times 10^{-4}$ \\
\hline 1971 & $6.5 \times 10^{-4}$ \\
\hline 1972 & $6.1 \times 10^{-4}$ \\
\hline 1973 & $6.7 \times 10^{-4}$ \\
\hline 1974 & $5.5 \times 10^{-4}$ \\
\hline 1975 & $8.2 \times 10^{-4}$ \\
\hline 1976 & $5.4 \times 10^{-4}$ \\
\hline 1977 & $6.9 \times 10^{-4}$ \\
\hline 1978 & $3.1 \times 10^{-4}$ \\
\hline 1979 & $6.1 \times 10^{-4}$ \\
\hline 1980 & $1.8 \times 10^{-4}$ \\
\hline 1981 & $6.9 \times 10^{-4}$ \\
\hline 1982 & $7.5 \times 10^{-4}$ \\
\hline 1983 & $9.2 \times 10^{-4}$ \\
\hline 1984 through 1995 & $1.0 \times 10^{-3}$ each year \\
\hline
\end{tabular}




\subsection{RECYCLED URANIUM MASS FLOW}

\subsection{RECYCLED URANIUM DESCRIPTION}

For purposes of the DOE recycled uranium mass balance project, RU has been defined as any uranium that has been irradiated in a reactor and, as a result, contains TRU material (e.g., $\mathrm{Pu}$ and $\mathrm{Np}$ ), fission products (e.g., Tc), and reactor-generated uranium products $\left({ }^{236} \mathrm{U}\right)$. The methodology applied in this $\mathrm{Y}-12$ Complex project for identifying the flow of RU materials includes the criteria of (1) the source site, (2) the isotopic constituents, and (3) the wt-\% assays of the material. Sites identified as RU source sites are the U.S. government facilities that operated production reactors and/or used chemical separation processes to extract uranium from irradiated fuel. Primary source sites are the Savannah River Site (SRS), the Idaho Chemical Processing Plant (ICPP), and Hanford. The majority of Y-12 Complex transfers with SRS and ICPP have involved RU (although significant quantities of fresh fuel and sweetener ${ }^{1}$ were also shipped to Savannah River). Secondary source sites providing RU materials to the Y-12 Complex are the Oak Ridge Gaseous Diffusion Plant (ORGDP) and the Paducah Gaseous Diffusion Plant (PGDP).

Data for Y-12 Complex material transactions with the RU source sites were extracted from Material Balance Reports (MBRs), shipment and receipt registers, historical summary reports, and individual Nuclear Material Transaction Reports. All of these reports were issued by the site Nuclear Material Control and Accountability (NMC\&A) organizations and provide official accountability data for all uranium and for other accountable nuclear materials at each site. Under the Y-12 Complex NMC\&A program, uranium is an accountable nuclear material; however, RU is not separately accountable.

The various reports reviewed included the name or symbol code of the accountability station where material was shipped or received, the material type, the amount of uranium, and the ${ }^{235} \mathrm{U}$ assay. It was necessary to review data at the Nuclear Material Transfer Report level (i.e., forms 101 and 741) to more accurately determine the material type and the ${ }^{235} \mathrm{U}$ assay because summary reports extracted from the same data often camouflaged the details of the material and assay.

While the methodology used in this project for identifying and tracking RU was the best available, it was imperfect, and so some loss of distinction between RU and non-RU material was unavoidable. Physical losses or discards of RU to the burial ground may have occurred which could not be identified and quantified. Loss of distinction also occurred as a result of blending RU with non-RU materials. Other losses of accountability may have occurred as a result of unavailable or ambiguous data.

Due to these limitations, the Project Team cannot claim with certainty that all activity related to the Y-12 Complex RU shipments, receipts, and inventories has been reviewed. However, the team believes this review is suitably comprehensive to have identified essentially all of the RU streams.

\footnotetext{
${ }^{1} \mathrm{HEU}$ used to blend with recycled uranium fuel feed to increase its enrichment is referred to as "sweetener."
} 


\subsection{URANIUM RECEIPTS}

Annual receipts of RU from the primary source sites included highly enriched RU from Savannah River and ICPP and slightly depleted RU from Hanford; these receipts are summarized in Table 3.2-1. Receipts of RU ICPP began in 1953, and receipts from Savannah River began in 1955. Some RU was received by the Y-12 Complex after 1989 but was not processed, primarily due to the Y-12 Complex stand down and the shutdown of the Savannah River reactors, which eliminated the need for recycled fuel.

Beginning in 1955, the Savannah River Site sent highly enriched uranyl nitrate (UN) solution to the Y-12 Complex in tanker trucks with a 3,800 - 5,000 gallon capacity. The concentration of the uranyl nitrate solution received from SRS was approximately $5 \mathrm{~g}{ }^{235} \mathrm{U} /$ liter. After evaporation, the material went through purification by solvent extraction, denitration to produce $\mathrm{UO}_{3}$, reduction to $\mathrm{UO}_{2}$, hydrofluorination to $\mathrm{UF}_{4}$, and "bomb" reduction to metal. The metal was cleaned and packaged for shipment back to Savannah River or placed in storage until Savannah River requested the material.

From 1972 to 1989, Savannah River sent ingot material of uranium-aluminum alloy (U-Al) for processing. This material was processed by first combining it with $\mathrm{NaOH}$ solution to dissolve the aluminum, which left sodium diuranate solids. The sodium diuranate was then dissolved in nitric acid, producing uranyl nitrate solution, which was purified and converted to metal. Not all of the U-Al material was processed, and some remains in storage at the Y-12 Complex today.

Savannah River also sent dross and furnace sweepings from the U-Al casting process, which were processed by $\mathrm{NaOH}$ dissolution to remove aluminum and then by nitric acid dissolution and finally purification and conversion to metal. Not all of this material was processed, and some remains in storage today at the Y-12 Complex. In total, Savannah River sent 125.2 MT of highly enriched RU to the Y-12 Complex. This flow of material between the Y-12 Complex and Savannah River is depicted in Figure 3.2-1.

The Y-12 Complex received 42.6 MT of slightly enriched RU $\left(0.74 \%{ }^{235} \mathrm{U}\right)$ from SRS that was transferred to Fernald. This material was received in five shipments which were transferred without repackaging; since this material did not contribute to personnel or environmental exposure, it is not included in this study.

From 1953 until the early-1990s, the ICPP processed spent Navy, research, and experimental reactor fuel to recover and recycle the HEU. The product of ICPP was sent to the Y-12 Complex for processing to metal and subsequent shipment to Savannah River. Initially, the product was UN solution; however, in 1971, a denitrator was installed, and subsequently, the product was uranium trioxide $\left(\mathrm{UO}_{3}\right)$. A total of $25.7 \mathrm{MT}$ of highly enriched RU was received at the Y-12 Complex from ICPP.

The Y-12 Complex received 1.5 MT of slightly depleted RU in the form of $\mathrm{UO}_{3}$ from Hanford with an assay of $0.65 \%{ }^{235} \mathrm{U}$. Because the assay is in the range of recovered uranium product of the Hanford reprocessing plant, it was assumed to be RU. Another 142 MTU received from Hanford was initially classified as RU, but this was determined to be unirradiated slugs returned from the Pile Enrichment Experiment and so was not included in this study.

Annual receipts of RU from sites other than Savannah River, ICPP, and Hanford are summarized in Table 3.2-2. Because the assay of the material received from these secondary sites was in the range of 0.59 to $0.69 \%{ }^{235} \mathrm{U}$, the material was assumed to be 


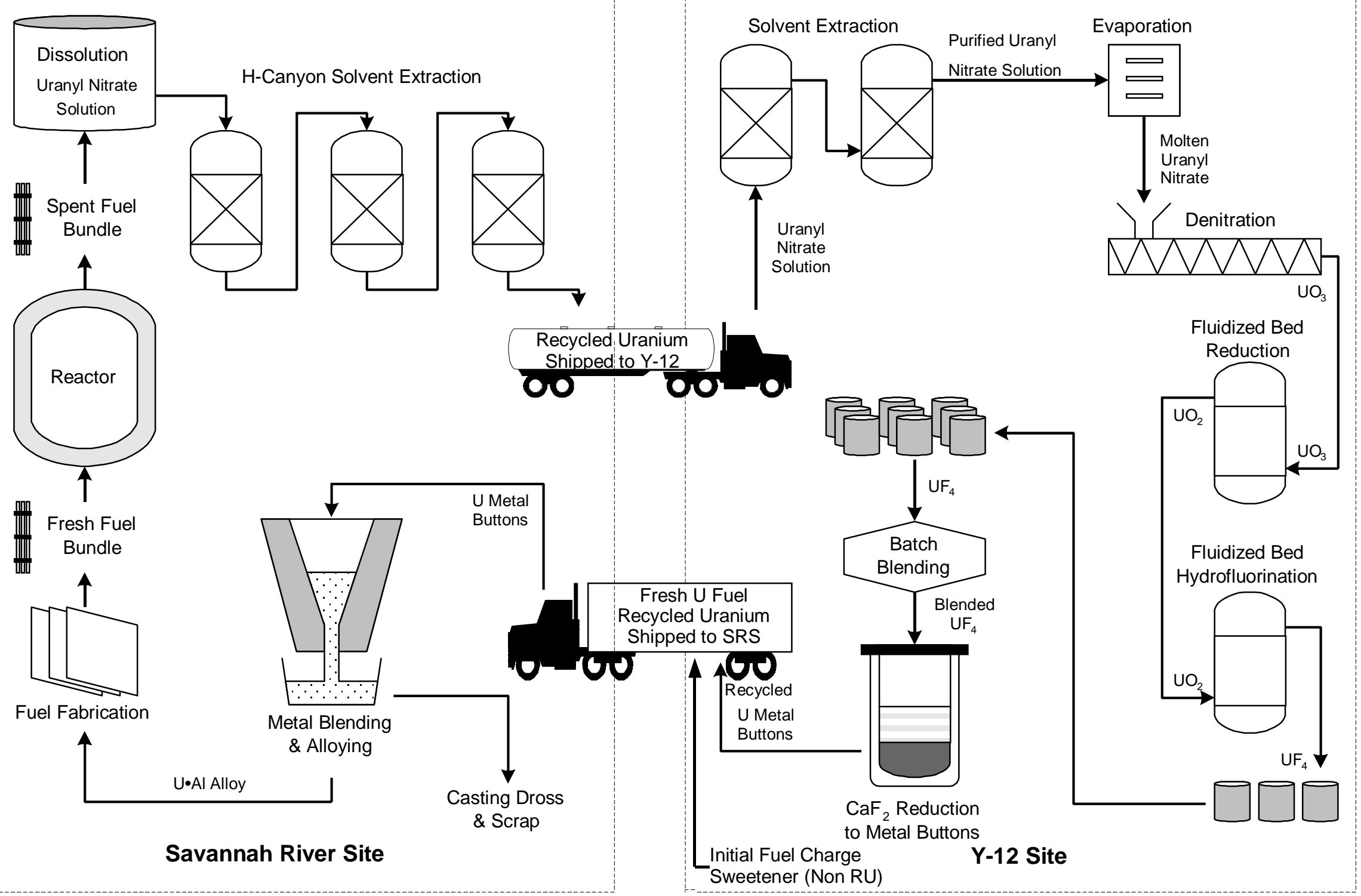

Fig. 3.2-1 Historical Savannah River Fuel Recycle Process 
Table 3.2-1 RU Received at the Y-12 Complex from Source Sites

\begin{tabular}{|c|c|c|c|c|c|c|c|}
\hline \multirow{2}{*}{$\begin{array}{l}\text { Fiscal } \\
\text { Year }\end{array}$} & \multicolumn{2}{|c|}{ Hanford } & \multicolumn{2}{|c|}{ ICPP } & \multicolumn{2}{|c|}{ Savannah River } & \multirow{2}{*}{$\begin{array}{l}\text { Total } \\
\text { kg U }\end{array}$} \\
\hline & kg U & Assay (\%) & kg U & Assay (\%) & kg U & Assay (\%) & \\
\hline 1953 & & & 102 & & & & 102 \\
\hline 1954 & & & 231 & & & & 231 \\
\hline 1955 & & & 828 & & 2 & 85 & 830 \\
\hline 1956 & & & 744 & & & & 744 \\
\hline 1957 & 9 & 0.680 & 797 & & 3 & 89 & 809 \\
\hline 1958 & 1,396 & 0.650 & 898 & & 18 & 82 & 2,312 \\
\hline 1959 & 82 & 0.650 & 3,741 & & 149 & 83 & 3,972 \\
\hline 1960 & 15 & 0.650 & 769 & & 6,235 & 85 & $7,01 \mathrm{c}$ \\
\hline 1961 & & & & & 2,058 & 84 & 2,058 \\
\hline 1962 & & & 775 & & 2,397 & 84 & 3,172 \\
\hline 1963 & & & & & 6,446 & 81 & 6,446 \\
\hline 1964 & & & 771 & & 2,978 & 81 & $3,74 \mathrm{C}$ \\
\hline 1965 & & & 425 & & 3,552 & 77 & 3,977 \\
\hline 1966 & & & 1,408 & & 3,700 & 73 & 5,108 \\
\hline 1967 & & & & & 2,502 & 69 & 2,502 \\
\hline 1968 & & & 394 & & 2,109 & 57 & 2,503 \\
\hline 1969 & & & 427 & & 4,090 & 62 & 4,517 \\
\hline 1970 & & & 108 & & 2,060 & 54 & 2,168 \\
\hline 1971 & & & 1,660 & & 3,500 & 57 & 5,160 \\
\hline 1972 & & & 413 & & 4,701 & 55 & 5,114 \\
\hline 1973 & & & 563 & & 5,070 & 57 & 5,633 \\
\hline 1974 & & & & & 4,581 & 55 & 4,581 \\
\hline 1975 & & & 1,702 & & 5,131 & 55 & 6,833 \\
\hline 1976 & & & 195 & & 4,312 & 50 & 4,507 \\
\hline 1977 & & & 1,333 & & 4,505 & 45 & 5,838 \\
\hline 1978 & & & 526 & & 2,078 & 47 & 2,604 \\
\hline 1979 & & & 535 & & 4,576 & 48 & 5,111 \\
\hline 1980 & & & (1) & & 1,489 & 59 & $1,48 \varepsilon$ \\
\hline 1981 & & & 905 & & 4,911 & 54 & 5,816 \\
\hline 1982 & & & 576 & & 5,719 & 50 & 6,295 \\
\hline 1983 & & & 1,041 & & 6,649 & 52 & 7,690 \\
\hline 1984 & & & 2,868 & & 4,870 & 57 & 7,738 \\
\hline 1985 & & & 1 & & 8,243 & 52 & 8,244 \\
\hline 1986 & & & 960 & & 5,718 & 56 & $6,67 \varepsilon$ \\
\hline 1987 & & & & & 4,575 & 57 & 4,575 \\
\hline 1988 & & & & & 3,095 & 53 & 3,095 \\
\hline 1989 & & & 1 & & 79 & 66 & 80 \\
\hline 1990 & & & & & 67 & 66 & 67 \\
\hline \multicolumn{8}{|l|}{1991} \\
\hline 1992 & & & & & 272 & 47 & 272 \\
\hline 1993 & & & & & 114 & 69 & 114 \\
\hline 1994 & & & & & 2,607 & 64 & 2,607 \\
\hline \multicolumn{8}{|l|}{ 1995-1999 } \\
\hline TOTALS* & 1,502 & $0.650^{\dagger}$ & 25,696 & $83^{\dagger}$ & $125,161^{\neq}$ & $60^{\dagger}$ & 152,359 \\
\hline
\end{tabular}


Table 3.2-2 RU Received at the Y-12 Complex from Secondary Sites

\begin{tabular}{|c|r|r|r|r|r|}
\hline $\begin{array}{c}\text { Fiscal } \\
\text { Year }\end{array}$ & \multicolumn{2}{|c|}{ ORGDP } & \multicolumn{2}{c|}{ PGDP } & \multicolumn{1}{c|}{ TOTAL } \\
\hline 1952 & $\mathbf{k g ~ U}$ & Assay (\%) & $\mathbf{k g ~ U}$ & Assay (\%) & \multicolumn{1}{c|}{$\mathbf{k g ~ U}$} \\
\hline 1953 & 1,381 & 0.650 & & & 1,381 \\
\hline 1954 & 2,370 & 0.641 & & & 2,370 \\
\hline 1955 & 137,015 & 0.673 & 1,550 & 0.629 & 138,565 \\
\hline 1956 & 22,871 & 0.660 & 36,440 & 0.670 & 59,311 \\
\hline 1957 & 7,588 & 0.670 & & 0.680 & 7,588 \\
\hline 1958 & 5,037 & 0.690 & 347 & & 5,384 \\
\hline 1959 & 11 & 0.620 & & & 11 \\
\hline 1960 & 2,093 & 0.640 & & & 2,093 \\
\hline TOTALS & $\mathbf{1 9 2 , 8 3 6}$ & & $\mathbf{3 8 , 4 2 3}$ & & $\mathbf{2 3 1 , 2 5 9}$ \\
\hline
\end{tabular}

* Numbers may not sum because of rounding.

RU. A total of 193 MTU was received from ORGDP in the form of oxide and metal. PGDP shipped 38 MT of RU, primarily fluorination tower ash, to the Y-12 Complex. Materials received from Fernald, but not included in this study, were 9,390 MT of DU metal made from gaseous diffusion plant tails for a special project and about $30 \mathrm{MT}$ of LEU.

Some reports indicate that 1.2 MT of UN residue was sent to the Y-12 Complex from West Valley, New York, in 1968. However, this material, recognized as ${ }^{233} \mathrm{U}$, was from Consolidated Edison Indian Point-1 Reactor fuel that was recovered by the Nuclear Fuel Services plant at West Valley and sent to Oak Ridge National Laboratory (ORNL) as uranyl nitrate solution for storage. In the 1970s, the ORNL Consolidated Edison Uranium Solidification Program (CEUSP) was initiated to solidify the material for longterm safe storage, and the CEUSP material remains in storage at ORNL today.

HEU material was received at the Y-12 Complex from Rocky Flats for processing as a routine part of the Y-12 Complex mission. Some of this material had surface $\mathrm{Pu}$ contamination, but none was identified as RU. Uranium received from Reactive Metals, Inc. (RMI) was low-assay DU that was determined to be below de minimis level and so excluded from further consideration.

\subsection{URANIUM SHIPMENTS}

Shipments of RU from the Y-12 Complex are shown in Table 3.3-1. From FY 1961 through FY1989, 120 MTU were sent to SRS. This RU was essentially all HEU metal. In addition, "fresh" HEU (amounting to approximately 70 MTU) was shipped to Savannah River to make up the original fuel charge for the production reactors when they converted to HEU fuel and to be used as sweetener to blend with and enrich the RU to make up the reload fuel elements.

Records indicate that $30 \mathrm{MTU}$ as $\mathrm{UF}_{4}$ in the assay range of $0.59-0.69 \%$ were shipped to PGDP from the Y-12 Complex. It is believed this material was part of the 38 MTU of slightly depleted ash previously identified as RU received from PGDP. 
Table 3.3-1 Y-12 Complex Shipments of RU

\begin{tabular}{|l|r|}
\multicolumn{1}{|c|}{ Receiving Site } & kg U \\
\hline ORGDP & 192,836 \\
\hline PGDP & 29,614 \\
\hline Savannah River & 120,384 \\
\hline TOTALS* & $\mathbf{3 4 2 , 8 3 4}$ \\
\hline
\end{tabular}

* Numbers may not sum because of rounding.

In addition, data reviewed at the Y-12 Complex indicate a high probability that the 193 MTU received from ORGDP was returned to ORGDP. This material may have been shipped to the Y-12 Complex for temporary storage. Although the data were not conclusive, receipts from ORGDP are assumed to have been returned to ORGDP for the purpose of estimating the Y-12 Complex mass balance receipts and shipments.

Shipments of material from the Y-12 Complex to Fernald, Rocky Flats, RMI, and Hanford were excluded from further consideration in accordance with the DOE Project methodology. The material shipped to Fernald was in a variety of forms, including lowassay DU, LEU, and a small quantity of HEU. The material sent to Rocky Flats was metal apparently made from $0.2 \%{ }^{235} \mathrm{U}$ gaseous diffusion plant tails. The shipments to RMI were low-assay DU billets, and those to Hanford were low-assay DU slugs.

\subsection{RECYCLED URANIUM WASTE}

Accountability data for uranium, as reported in the documentation reviewed, does not identify losses at a level that can be associated specifically with RU. However, the Project Team was informed by individuals familiar with enriched uranium processing that standards for normal operating losses for once-through processing are approximately 0.5\%. During the period of 1953 through 1989, the Y-12 Complex processed approximately 151 MT of highly enriched RU from SRS and ICPP. Solvent extraction raffinate from processing this material was isolated at Building 9206 and transported to the Building 9212 complex. This raffinate was mixed with the raffinate from Building 9212 and processed prior to discarding in the S-3 Ponds. After the mid-1980s, the raffinate was transferred to the West End Treatment Facility. The total RU waste is expected to be less than $100 \mathrm{~kg} \mathrm{U}$.

Discussions with individuals who worked at the Y-12 Complex from the 1950s to about 1990 indicated that the plant did not have the capability nor the need to chemically process slightly depleted uranium in the assay range of 0.59 to $0.69 \%{ }^{235} \mathrm{U}$. It is also known that significant quantities of slightly depleted RU were sent to the Y-12 Complex for storage prior to burial or disposition to other Oak Ridge Operation sites. Therefore, it is assumed that the depleted RU from Hanford, ORGDP, and some from PGDP (a total of approximately $205 \mathrm{MTU}$ ) was disposed of in this manner. Since these materials were apparently not processed or handled directly at the Y-12 Complex, they are not considered to be potential sources of personnel or environmental exposure.

2 This does not include the slightly enriched RU from Savannah River that was transferred to Fernald immediately upon receipt in the same containers. 


\subsection{RECYCLED URANIUM SCRAP}

The primary source of scrap was from the processing of HEU for shipment to Savannah River. Scrap would have been generated in the process of producing metal buttons from the reduction of $\mathrm{UF}_{4}$ and, in very small amounts, in the fracturing of the buttons to meet the Savannah River specifications. The scrap was recycled to reclaim the uranium. Insignificant losses would have entered the extraction process raffinate stream under normal operation.

\subsection{INVENTORY AS OF MARCH 31, 1999}

As of March 31, 1999, approximately 13 MT of RU in the form of HEU metal buttons and $\mathrm{U}-\mathrm{Al}$ alloy remained at the Y-12 Complex.

\subsection{ESTIMATED MASS BALANCE FOR RU}

An estimated mass balance for the Y-12 Complex is shown in Table 3.7-1. The mass balance was estimated by comparing the RU received at the plant with a total for the RU shipped, the current inventory, an estimate of RU waste, and depleted RU that was buried or transferred from the plant to other ORO sites for disposition.

Table 3.7-1 Estimated RU Mass Balance for the Y-12 Complex

\begin{tabular}{|c|c|c|}
\hline & $\begin{array}{l}\text { RU Received } \\
\text { (kg U) }\end{array}$ & $\begin{array}{l}\text { RU Shipped } \\
\text { (kg U) }\end{array}$ \\
\hline Savannah River & 125,161 & 120,384 \\
\hline ICPP & 25,696 & 0 \\
\hline Hanford & 1,502 & 0 \\
\hline ORGDP & 192,836 & 192,836 \\
\hline PGDP & 38,423 & 29,614 \\
\hline TOTAL & 383,618 & 342,834 \\
\hline Total RU Shipped & & 342,834 \\
\hline RU Inventory (as of $3 / 31 / 99$ ) & & 13,082 \\
\hline Estimated RU Waste & & $\sim 100$ \\
\hline Depleted RU Buried/Disposed & & 10,311 \\
\hline TOTAL & 383,618 & 366,327 \\
\hline Difference* & & $\sim 17,300$ \\
\hline
\end{tabular}


The mass balance data reported in this table agree with reconciliation information provided by Hanford and Idaho. The reconciliation also resulted in agreement that material shipped from Fernald was not RU.

The total uranium received from Savannah River was 179 MTU, a difference of 54 MTU when compared with the 125 MTU reported in the table. This discrepancy is explained by receipts from SRS that included 43 MT of LEU received at the Y-12 Complex and which was shipped to Fernald almost immediately. This RU was not removed from the shipping containers nor processed at the Y-12 Complex. Since there is no possibility of Y-12 Complex site environmental exposure, this RU was not added to the various Y-12 Complex report tables representing RU data. In addition, approximately 10 MT of non-RU weapon components sent earlier to Savannah River were returned from SRS and included in receipts, and approximately 1 MTU of miscellaneous LEU was received from SRS.

Total uranium shipped from the Y-12 Complex to SRS was approximately 190 MTU, a difference of 70 MTU when compared with the 120 MTU reported in the table.

Savannah River received instructions from DOE that they should report all receipts and shipments involving the Y-12 Complex as RU. The primary item reconciling Y-12 Complex shipments with SRS data is $70 \mathrm{MTU}$ fresh fuel, sweetener, and weapon components determined by the Y-12 Complex to be non-RU. Savannah River also reported small quantities of NU and LEU as RU that were considered by the Y-12 Complex to be non-RU.

A discrepancy of 17.3 MTU between overall receipts and shipments (plus inventory, waste, and buried/otherwise disposed) reflects an inability to precisely distinguish between the RU and non-RU shipments and receipts between the Y-12 Complex and Savannah River and other sites. The only way to distinguish between fresh fuel (non-RU) and sweetener (also non-RU) and RU, using available records, is by enrichment level. The Project Team estimated the enrichment of each shipment and assumed that shipments of $\leq 90 \%$ enrichment were RU. Shipments of $>90 \%$ enrichment were assumed to be fresh fuel or sweetener, non-RU material. This methodology using enrichment level to distinguish between RU and non-RU results in good estimates of RU flows that are reasonably consistent with Savannah River estimates. Although this is the best available means of distinguishing RU streams, this method does leave a difference of approximately 17.3 MTU between receipts and shipments.

Included in the overall mass balance for RU is highly enriched RU, which is of most concern for worker exposure. An estimated mass balance for just the highly enriched RU is shown in Table 3.7-2. A total of approximately 151 MT of highly enriched RU was received from Savannah River and ICPP, and in return, approximately 120 MT of highly enriched RU was shipped to Savannah River. 
Table 3.7-2 Estimated Mass Balance for Highly Enriched RU

\begin{tabular}{|c|c|c|}
\hline & $\begin{array}{l}\text { RU Received } \\
\text { (kg U) }\end{array}$ & $\begin{array}{c}\text { RU Shipped } \\
\text { (kg U) }\end{array}$ \\
\hline Savannah River & 125,161 & 120,384 \\
\hline ICPP & 25,696 & 0 \\
\hline TOTAL & 150,857 & 120,384 \\
\hline Total RU Shipped & & 120,384 \\
\hline RU Inventory (as of $3 / 31 / 99$ ) & & 13,082 \\
\hline Estimated RU Waste & & $\sim 100$ \\
\hline TOTAL & 150,857 & 133,566 \\
\hline Difference* & & $\sim 17,300$ \\
\hline
\end{tabular}




\subsection{CONSTITUENTS IN RECYCLED URANIUM}

\subsection{INFORMATION SEARCH AND DATA SOURCES}

The Project Team searched a variety of data collections, libraries, and records centers at the Y-12 Complex to identify and retrieve analytical data. Most of the data was located in incidental administrative files in buildings 9115, 9206, and 9212 or was contained within electronic databases prepared to support current programs at the plant. While the majority of data on uranium transactions (shipments and receipts) was located at the Y-12 Complex Records Center, the search of the records center did not, in general, produce relevant analytical data. Major data sources consulted and analyzed included:

- Radiological Control Organization (RADCON) historical summary reports for operations (e.g., uranium radioactivities reports) and laboratory analysis results reports maintained in retained files of a past RADCON staff health physicist,

- $\quad$ specifications and correspondence between shippers and receivers regarding specifications,

- DOE and contractor reports addressing RU,

- DOE and contractor correspondence and assessments addressing transuranic hazards,

- recent environmental survey and safety basis reports (e.g., Basis for Interim Operation, characterization reports),

- Y-12 Complex technical reports describing operations and production processes, and

- environmental reports submitted to state and federal agencies.

Data was gleaned from the variety of sources identified. Correspondence between shippers and receivers also provided a record for comparisons with sets of analytical data. In addition, data were compared and shared with other DOE sites as appropriate. For some areas that presented gaps in data, the Project Team estimated constituent levels. Estimates were based on extrapolations from actual data and represent (1) application of known data to material of similar origin or processing or (2) application of known data from a specific time period over a longer time period. All such estimates or engineering judgments and their bases are specifically identified in this report.

The approach used in searching for and collecting data useful to the project was suitably comprehensive for targeting the broad range of likely sources and locations of data. However, because of time and resource limitations, the Project Team could not absolutely verify that all relevant and usable analytical data and records were identified and reviewed.

As a result of the brief but intensive search, the team determined that a significant amount of information exists to address the scope and objectives established for this phase of the RU project. Further, results of this current effort have extended previous evaluations and have, in some instances, served to confirm earlier work. With respect to constituent analysis, a reasonable quantity of data was found and evaluated. 


\subsection{ANALYTICAL LABORATORIES}

The Y-12 Complex Laboratory, Building 9995, performed the analytical measurements and radiochemistry in support of Y-12 Complex production processing, including the recycled uranium receipt, storage, processing, and transportation. This included analyses for receipt and product specification verification, mid-stream processing, and the health physics worker protection program. Internal correspondence from 1958 to the present documents ongoing communications between operations (production and processing), analytical laboratories, and health physics staff regarding material specifications and worker radiological issues. Written communications confirm a routine sampling program with analytical measurements for TRU and fission products in RU. Specification and action value limits for the Y-12 Complex were established and used.

Additionally, as requested, the ORNL Low Level Radiochemistry Laboratory performed chemical separations with alpha spectrometry for specific low-level radiochemical analyses, and the ORNL Mass Spectrometric Analysis Laboratory located at the Y-12 Complex performed specific isotopic analyses (e.g., plutonium). The Lockheed Martin Energy Systems Analytical Services Organizations laboratories performed urinalysis measurements in support of the Y-12 Complex Radiological Control Program in later years.

The Y-12 Complex Laboratory historically retained copies of customer reports for 1 year, after which the reports were sent to the Y-12 Complex Central Records, which retained records for 3-5 years. In the early years, analytical results were documented on paper reports or customer-designed forms (e.g., Uranium Radioactivities Reports) generated in-house for the requesting organization, such as Radiation Safety/Health Physics. 1 Uranium Radioactivities Reports documented the production batch sampling and analytical laboratory analyses for the $U$ recycling process material and streams. Alpha activity, non-uranium actinides (i.e., ${ }^{238} \mathrm{Pu},{ }^{239,240} \mathrm{Pu},{ }^{237} \mathrm{~Np}$, and ${ }^{228} \mathrm{Th}$ ), total actinides, ${ }^{232} \mathrm{U}$, beta activity, and gamma activity were measured for various stages or steps in the material processing streams, including raffinate, secondary extraction feed, primary extraction feed, $\mathrm{UO}_{3}$, and $\mathrm{UF}_{4}{ }^{2} \mathrm{Lab}_{\mathrm{L}}$ results were compared to established specification and action value limits. The report was revised over time as the specifications were modified, e.g., with alpha ratio. A typical data report for the Radiation Safety/Health Physics organization to be completed and transmitted by the Y-12 Complex Laboratory is shown in Figure 4.2-1.

In the 1970s the CERTAN database was designed and implemented for weapons stream certification. This database included SRS-processed material product, e.g., metal buttons. In the 1980s, the Y-12 Complex Laboratory implemented a Laboratory Information Management Systems (LIMS). Analysis results were entered by hand into LIMS, and computer-generated reports were printed and transmitted to the customer.

\footnotetext{
${ }^{1}$ Internal Correspondence, SRP Specifications Revisions, W.H. Tipton to J.R. Barkman, March 17, 1979.

${ }^{2}$ Production Schedules: Uranium Radioactivities Reports, Loden to McAllister.
} 


\section{URANIUM RADIOACTIVITIES REPORT}

Sample Type: Stream

Material

Date

Requisition No.

Identification No.

\section{Requested Analyses}

Spec. Action Value

(Reported Value Units)

Reported Value

Alpha Activity

Non-uranium Actinides

$\mathrm{Pu}-238,239-40$

Np-237

Th-228

Others (list)

Total Actinides

Uranium-232

$\mathrm{U}$

Total U Alpha ${ }^{(1)}$

$\mathrm{U}$

$\alpha$ Ratio:(2) Actinide Activity x 700 Uranium Activity

$<0.0<0.04$

$<1.4<0.7$

$<250<200$

$<1.0 \quad<0.4$

Beta Activity

$\beta$ Ratio: Activity of Sample(3) Activity of U Std.

Gamma Activity, Fission Product

$$
\text { Cs-137 }
$$

$\mathrm{Ce}$

$\mathrm{Zr}-\mathrm{Nb}-95$

Ru-106

Others (list)

Total Fission Product $\gamma$

Total Gamma
0.20

0.05

0.20

$<0.50<0.2$

$<2.0$

$<0.1$
$\mathrm{uCi} / \mathrm{g} \mathrm{U}$ $\mathrm{uCi} / \mathrm{g} \mathrm{U}$ $\mathrm{uCi} / \mathrm{g} \mathrm{U}$ $\mathrm{uCi} / \mathrm{g} \mathrm{U}$ $\mathrm{uCi} / \mathrm{g} \mathrm{U}$ $\mathrm{d} / \mathrm{min} / \mathrm{ug}$ $\mathrm{uCi} / \mathrm{g} \mathrm{U}$ $\mathrm{d} / \mathrm{min} / \mathrm{ug}$
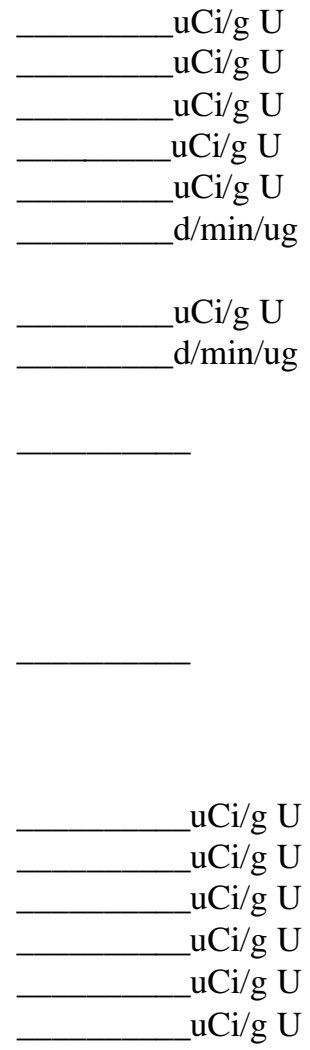

ug/Ra-226 Eq. $\mathrm{g} \mathrm{U}$

(1) Calculated from isotopic abundances.

(2) Actinide activity d/min/ug $\mathrm{U}$ and nominal value of $140 \mathrm{~d} / \mathrm{min} / \mathrm{ug} \mathrm{U}$ activity

(3) Uranium enriched ${ }^{235}{ }^{23}$ to $93 \%$. (No transuranics or fission products present.)

Fig. 4.2-1 Uranium Radioactivities Report. 


\subsubsection{Analytical Procedures}

Written procedures were prepared, approved, and used for the analytical methods performed by the Y-12 Complex Laboratory in support of uranium recycle transportation, storage, and processing. Procedures were also written and approved for operations organizations in support of the uranium recycle program and associated analytical measurements. Y-12 Complex Procedures established a schedule for sampling and reporting fission-product and transuranic impurities in enriched uranium materials. ${ }^{2}$ The procedures describe the materials to be sampled, the frequency of sampling, the required analyses, and the distribution of results.

\subsubsection{Analytical Methods and Errors}

Analytical methods performed by the Y-12 Complex Laboratory in support of recycled uranium receipt, transportation, storage, processing, and health physics included potentiometric titration, sodium dichromate titration, X-ray fluorescence, electrodeposition, Davies-Grey, gross alpha, gross beta, gross gamma, alpha spectroscopy, thermal ionization mass spectrometry (TIMS), liquid/liquid extraction, and ion exchange column chromatography. The Isotope Dilution Mass Spectrometry (IDMS) method for isotopic analysis was performed by the ORNL Mass Spectrometry Laboratory when requested. The analytical methods changed over the processing years as the chemical separation and isotopic measurement methods improved and as new technologies became available.

Limits of error, detection limits, and quality assurance requirements were specified in the procedures and according to the method used. Analytical methods and precision were also specified in shipping agreement between the Y-12 Complex and the Savannah River Site. The shipping agreement plan for October 1986 states, "The uranium solution analysis is performed using the Davies-Grey Method whose precisjon and accuracy are within +/- $0.2 \%$. Isotopic content is determined by mass spectrometry." ${ }^{-1}$ This is specified for both the shipper and the receiver. As required, duplicates for sample analyses were obtained and measured, and in some cases samples were combined to form a "composite." Quality assurance requirements were also communicated to the laboratory regarding inspection and analysis on product material, i.e., metal buttons; "for quality assurance, laboratory results for ${ }^{235} \mathrm{U}$ assay could not vary by greater than 0.3 percent from the value calculated based on the $\mathrm{UF}_{4}$ mixing ratio.' 5 Documentation shows that quality assurance requirements flowed from the Savannah River material specifications ${ }^{\mathrm{L}}$ to Y-12 Complex analytical laboratory procedures, operations procedures, and plans.

In early 1958, isotopic analysis for plutonium would have been performed at ORNL using the Pulse Analysis technique. "The specific activity for the plutonium was calculated

\footnotetext{
${ }^{3}$ Martin Marietta Energy Systems, Sampling Enriched Uranium for Fission Product and Transuranic Impurities, 1988.

${ }^{4}$ Oak Ridge Y-12 Plant - Savannah River Plant, Shipping Agreement Plan, October 1986.

${ }^{5}$ Lockheed Martin Energy Systems, "Grouping Uranium Metal Buttons for the Off-Specification Fuel Project," 1999.

${ }^{6}$ Savannah River Plant, “Essential Material Specification 97: Recycled Enriched Uranium,” May 4, 1988.
} 
based upon the ORNL pulse analysis of six $\mathrm{Pu}-238$ pulses to one $\mathrm{Pu}-239+240$ pulse. Up until this time total $\mathrm{Pu}$ contamination permissible limits were reported in units of $\mathrm{ppb}$. Without the correct specific activity values for the uranium and plutonium in each batch, which varies with the isotopic content, one cannot determine the parts per billion by the usual alpha counting methods."

The Y-12 Complex Laboratory, then and today, comprises several individual, cofunctioning laboratories, including Special Processing, Isotopic Lab, and Radiochemistry, each with unique functions. Depending upon the analyses requested, each lab would receive a respective aliquot from a sample. For incoming RU material, the Y-12 Complex Laboratory was typically asked to perform three analyses: $\mathrm{g} \mathrm{U} / \mathrm{g}$ solution, $\mathrm{U}$ isotopics, and density measurements. Results were transmitted to NMC\&A, which then converted the results to g/liter with the density value. The Y-12 Complex Laboratory staff confirmed that Tc was not measured separately by the Y-12 Complex Lab but was included in the "Total Beta/Gamma Activity." Total Gamma Activity was measured for specific gamma-emitting isotopes (fission products), e.g., ${ }^{137} \mathrm{Cs}$ and ${ }^{106} \mathrm{Ru}$, as noted on sample reports. A brief summary of the methods used and general timeframes is provided below. ${ }^{8}$

Total U - g/g U Measurement

- 1960 s - Potentiometric Titration

- $\quad$ 1970s to mid 1980s - Sodium Dichromate Titration Method, X-Ray Fluoresence

- $\quad$ late 1980s to 1990s - Davies-Grey Method (used on SRS material until 1989)

- $\quad$ after 1998 - IDMS with TIMS

Total Alpha and/or with Isotopic Measurements (e.g., transuranics)

- before 1979 (before alpha spectroscopy existed) - Y-12 Complex Radiochemistry Lab performed separation chemistry for U using trioctyl and tridecyl amines (TTA) or tributyl phosphate (TBP) solvent extraction to clean up and extract $U$ from other constituents, followed by simple gross alpha measurement

- after 1979 - Y-12 Complex Radiochemistry Lab performed separation chemistry for U and other alphas using ion exchange column separation chromatography to selectively separate alpha-emitting isotopes, followed by alpha spectrometry (1980-1990s)

- $\quad$ after 1998 - IDMS with TIMS

\subsection{HISTORIC STANDARDS AND SPECIFICATIONS FOR TRANSURANICS AND FISSION PRODUCTS IN RECYCLED URANIUM}

Both RADCON-type and product-type standards/specifications were developed and used at the Y-12 Complex to address radiological safety concerns associated with the presence of TRU and fission products in RU materials received, processed, and shipped. Under the successive oversight of the AEC, ERDA, and DOE, the formality of the associated documentation increased, especially with the explicit RADCON-type specifications. However, either through product specifications, RADCON-type specifications, or a

\footnotetext{
${ }^{7}$ Internal Correspondence, "Plutonium Contamination in ARCO Uranium Salvage Solutions," G.R. Patterson to F.M. Tench, March 18, 1958.

${ }^{8}$ Meeting with Y-12 Complex Laboratory staff, August 2000.
} 
combination of both, limits were placed on acceptable levels of TRU and fission products in RU received and processed for shipment from the beginnings of the RU program in 1953. Internal Correspondence Reports for DOE and the Y-12 Complex subcontractors (Union Carbide Nuclear Division, Martin Marietta Energy Systems, and Lockheed Martin Energy Systems) document that the Y-12 Complex Health Physics organization conducted "a continuing effort to evaluate transuranics and fission product contamination in SRO shipments and the amount of Pu in Rocky Flats (RF) returns."

Plant documentation and correspondence confirms that all reactor material returns contained some radioactive constituents. Specifications or limits were established to keep the levels of transuranic and fission-product constituents in the reactor returns to a level that would not significantly affect exposure potential for Y-12 Complex personnel. To ensure that the hazards from constituents of concern in RU were small relative to that of uranium, feed specifications were established for the Y-12 Complex receipts. Specifications were established for both the shipper (e.g., Savannah River Site) and the receiver (the Y-12 Complex). As long as these specifications were met, the RU was treated essentially the same as DU or enriched uranium. Batch sampling for receipt shipments was conducted to ensure that the specifications were being met. Measurements exceeding specifications were evaluated and special controls were instituted as warranted.

\subsubsection{Historic Standards/Specifications (early years to 1985)}

In the beginning of the Y-12 Complex's RU operations, Pu was limited to <10 ppb, based upon material concentration criteria. In 1958, this level was reevaluated in terms of the relative hazard as compared to uranium. Correspondence between Health Physics and Chemical Processing emphasizes the importance of the relationship between plutonium contamipation limits permitted in enriched uranium salvage solutions and radiological health hazards. ${ }^{10}$ As noted above, initial Pu contamination concentrations were reported in mass units, e.g., ppb. New limits were needed for worker protection based upon maximum permissible concentrations in air. Four alternative solutions to the problem of processing plutonium-contaminated uranium salvage solutions were evaluated and "the decision was made to limit the amount of plutonium contamination permitted so that the maximum permissible air-borne concentration for the mixture of isotopes in air would not be significantly less than the limit already in use for enriched uranium alone." As a result, a limitation was derived which established that the ratio of $\mathrm{Pu}$ to $\mathrm{U}$ could not exceed 1 disintegration per minute (dpm) Pu per 700 dpm of $U$ :

\section{$\underline{1 \mathrm{dpm} \mathrm{Pu}}$ \\ $700 \mathrm{dpm} \mathrm{U}$}

At this level, uranium would be the hazard of concern, and no adjustments would have to be made to the Plant Acceptable Limit (PAL) for airborne radioactivity, which at this time

\footnotetext{
${ }^{9}$ Internal Correspondence, "Savannah River Operations (SRO) and Rocky Flats(RF) Returns,” C.M. West to J.R. Barkman, May 12, 1981.

${ }^{10}$ Internal Correspondence, "Plutonium Contamination in ARCO Uranium Salvage Solutions," G.R. Patterson to F.M. Tench, March 18, 1958.
} 
was $70 \mathrm{dpm} /$ cubic meter. It was recognized that this more conservative limit would be one that fit both the radiological health hazard and material concentration criteria. 11

A 1960 letter from Health Physics to Chemical Processing reaffirmed the use of the $1 \mathrm{dpm} \mathrm{Pu} / 700 \mathrm{dpm} \mathrm{U}$ ratio and the PAL for airborne radioactivity of $70 \mathrm{dpm} /$ cubic meter as the standards for control of plutonium concentrations in incoming salvage solutions. The letter reinforced the need to monitor plant airborne concentrations and the established air limits. ${ }^{12}$ A follow-up letter in 1960 clarifies the potential implications of higher $\mathrm{Pu}$ concentrations in incoming material for both the established air limits and the urinalysis program. It also confirms the original recommendations to limit the plutonium concentration ratio. 13 A 1961 letter documents recommendations from Health Physics to Chemical Processing for changes in specific activity (SA) of incoming SRS material. ${ }^{14}$ A 1967 letter documents evaluation of the alpha ratio for incoming Pu-contaminated uranium against the existing criteria, discusses the health physics significance, and communicates additional recommendations for processing. 15

In addition to approved Plant Action Limits and Specifications, suggested guidelines were developed jointly by Health Physics and Chemical Operations staff as additional means of radiation control for reactor product materials. As noted in a 1975 letter, these guidelines are morespecific and acknowledge that other constituents in the RU processing could be present.

Alpha Radiation

non-uranium actinides

$<0.10 \mu \mathrm{Ci} / \mathrm{g} \mathrm{U}$

actinide/uranium ratio

$<1 \mathrm{dpm} \mathrm{Pu} / 700 \mathrm{dpm} \mathrm{U}$

total (including SA of U)

$<113 \mu \mathrm{Ci} / \mathrm{g} \mathrm{U}$

Beta Activity $2 \div\left({ }^{238} \mathrm{U}\right.$ fraction $) \mathrm{x}$ (activity from unirradiated $\mathrm{U}$ of similar enrichment)

Gamma Radiation (Upper Limits) gamma from fission products $0.2 \mu \mathrm{Ci} / \mathrm{g} \mathrm{U}$ total gamma $2.0 \mu \mathrm{g}$ radium equivalents/g $\mathrm{U}$

$\underline{\text { Radionuclide Analyses (Upper Limit) }}$ ${ }^{232} \mathrm{U}$

$0.03 \mathrm{ppm} / \mathrm{g} \mathrm{U}$

11 Ibid.

12 Internal Correspondence, "Plutonium Contamination in SRO Uranium Salvage Solutions," J.D. McLendon to J.S. Reece, September 6, 1960.

${ }^{13}$ Internal Correspondence, "Health Physics Considerations of Plutonium Contamination in SRO Uranium Salvage Solutions,” J.D. McLendon to J.S. Reece, October 24, 1960.

${ }^{14}$ Internal Correspondence, "Specific Activity - Incoming SRO Material," M.B. Edwards to J.R. Barkman, December 18, 1961.

${ }^{15}$ Internal Correspondence, "Pu Contaminated Uranium," C.M. West to J.R. Barkman, March 2, 1967.

${ }^{16}$ Internal Correspondence, "SRP and ICPP Specifications," W.H. Tipton to J.R. Barkman, June 25, 1975. 
A "Uranium Radioactivity and Radioactive Contaminants" Report in the Special Analysis and Sampling Plan, from C.M. West to J.R. Barkman, dated February 18,1977, documents the laboratory analyses for alpha, beta, and gamma activities requested by Health Physics, the accepted specification values, and the desired reporting values. ${ }^{17}$ The 1977 early version of the report was revised in 1979. "Uranium Radioactivities Report" for Savannah River and Idaho materials documents that analytical laboratory analyses were modified and additional analyses requested as needed to accommodate revisions to the Savannah Riverspecifications. It documents the use of Action Values in addition to the specifications. 18

As the RU campaign proceeded and processing issues were evaluated, the sampling frequency for various streams and side streams was modified. A 1977 letter documents the change in sampling frequency on SRS residues from annual to quarterly. $\frac{19}{19}$

A change in alpha ratio calculations, from "actinide-to-uranium alpha ratios on reported uranium alpha activity (for SRO receipts), to using the nominal value of: $\mathrm{dpm} / \mu \mathrm{g}$ of total actinide x $700 / 140 \mathrm{dpm} / \mu \mathrm{g}$ (nominal SA of $\mathrm{U}$ ) $=<1$," is documented in internal correspondence dated November 29, 1977. 20

A 1979 letter from Health Physics to Chemical Processing reaffirms the use of specification limits for alpha, beta, and gamma activities. A review of summarized annual 1977 and 1978 results are presented for receipts, shipments of metal and oxide, and side streams, including secondary feed, raffinates, and residues. The letter also describes the addition of analysis checks on other side streams (e.g., $\mathrm{Pu}$ and $\mathrm{Np}$ on the $\mathrm{UF}_{4}$ side stream) as needed in meeting material specifications. 21

Alpha Ratio

$\mathrm{dpm} / \mu \mathrm{g}$ total actinide $\mathrm{x} 700$

$140 \mathrm{dpm} / \mu \mathrm{g}$ (normal specific activity of "Oralloy"-

$$
=<1
$$

the Y-12 Complex product)

Beta Ratio

activity of sample

activity of $\mathrm{U}$ sample enriched in ${ }^{235} \mathrm{U}$ to $93 \%$

with no transuranics, fission products

Total Gamma

$\mu \mathrm{g} /{ }^{226} \mathrm{Ra}$ equivalent per gram $\mathrm{U}$

$$
=<1.25
$$

Internal correspondence documents a study and evaluation performed on the 1977 annual results. 22 A portion of the comments, explanations, and follow-up actions are presented below:

\footnotetext{
${ }^{17}$ Internal Correspondence, "Special Analysis and Sampling Plan,” C.M. West to A.R. Flynn, February 18, 1977.

${ }^{18}$ Internal Correspondence, "SRP Specifications Revisions,” W.H. Tipton to J.R. Barkman, March 17, 1979.

${ }^{19}$ Internal Correspondence, "Special Analysis and Sampling Plan," C.M. West to J.R. Barkman, May $18,1977$.

${ }^{20}$ Internal Correspondence, "Alpha Ratios on SRO Solution Shipments," C.M. West to J.R. Barkman, November 29,1977.

${ }^{21}$ Internal Correspondence, "SRO Results," C.M. West to J.R. Barkman, April 26, 1979.

${ }^{22}$ Internal Correspondence, "SRO Sample Results," C.M. West to W.H. Tipton, January 6, 1978.
} 
- "SRO receipts exceeded the alpha ratio specification for transuranics on shipments 77-10 through -12 . This was primarily due to the ${ }^{237} \mathrm{~Np}$ concentration. The high ${ }^{237} \mathrm{~Np}$ concentration was called to the attention of Savannah River. Savannah River subsequently made changes in its process, which decreased the ${ }^{237} \mathrm{~Np}$ concentration and brought the alpha ratio back into our specification."

- "SRO shipments showed lower levels on alpha and beta ratios and total gammas, indicating that there is some cleanup of transuranics, thorium and fission products by our processing."

- "The analyses of regular stream metal show levels consistent with past findings and indicate no significant crossover of actinides or beta or gamma emitters between the Savannah River and regular production streams."

- "In the raffinate and residue side streams, there was a buildup of the total gamma results as well as in the alpha and beta ratios. This buildup was consistent with past experience."

- "Measurements made at strategic points outside of the 9206 SRO process equipment did not indicate any buildup of penetrating radiation of personnel exposure significance."

Internal correspondence defines and confirms the specifications currently in use at the time. The specifications were designated in three parts as total alpha, total beta, and total gamma activity. The alpha ratio was developed to ensure that the relative hazard potential of an alpha emitter other than uranium was a maximum of $7 \%$ of the relative hazard potential of uranium. The beta ratio and the total fission product specifications were selected to ensure that there would be no significant addition to the exposure potential of Y-12 Complex workers. It also confirms that there is some concentration of contaminants in both liquid and solid-waste streams. The specifications, per 1985 internal correspondence, $\frac{\text { 23 }}{\text { state that: }}$

Alpha Activity alpha ratio:

(activity per gram $\mathrm{U}$ of $\mathrm{Pu}+\mathrm{Np}+\mathrm{Th}) 700$ nominal activity of enriched $\mathrm{U}$

$<1.0 \mu \mathrm{Ci}$

Beta Activity

beta ratio:

activity of sample

$<1.25 \mu \mathrm{Ci}$

activity of unirradiated uranium standard

Gamma Activity

total fission products:

$$
\frac{0.5 \mu \mathrm{Ci}}{\mathrm{g} \mathrm{U}}
$$

\subsubsection{Historic Standards/Specifications (1986 to 1995)}

The 1:700 ratio for alpha remained essentially unchanged throughout all RU operations until early 1986, when it was changed to 1:1000 to reflect changes in applicable derived air concentration limits. In September 1985, the Y-12 Complex submitted revised specifications

\footnotetext{
${ }^{23}$ Internal Correspondence, "Radioactive Contaminants in Uranium Reactor Returns Processed at Y-12," J.B. Hunt to E. Owings, September 11,1985.
} 
to DOE-ORO. ${ }^{24}$ On October 25, 1985, DOE-ORO approved the modified specifications for radiological impurities in recycle material proposed for shipments and receipts at the Y-12 Complex. ${ }^{25}$ The effective date of the new specification was to be no later than January 1, 1986. Revised specifications were also a recommendation from the Joint Task Force on Recycle Materials Processing. 26

\section{$\underline{\text { Y-12 Complex Specifications for Recycle Material Shipments and Receipts }}$}

I. Alpha Activity

The total transuranic alpha activity shall not exceed 0.1 percent of the uranium alpha activity.

II. Beta Activity

The ratio of the beta activity in the recycled uranium material to the beta activity of an equivalent amount of unirradiated $93 \%$-enriched ${ }^{235} \mathrm{U}$ shall not exceed 1.25.

III. Gamma Activity

Total gamma activity from fission product and induced-activity radionuclides shall not exceed $1.2 \mu \mathrm{Ci} / \mathrm{g} \mathrm{U}$. The gamma activity from individual isotopes shall not exceed the following:

A. Uranium Compounds

\begin{tabular}{|l|c|}
\multicolumn{1}{c|}{ Radionuclide } & Maximum Gamma Activity \\
\hline Cerium & $\boldsymbol{\mu C i / g}$ \\
\hline Ruthenium & 0.3 \\
\hline Cesium & 0.3 \\
\hline Zirconium-Niobium-95 & 0.1 \\
\hline Any other individual radionuclide & 0.5 \\
\hline
\end{tabular}

B. Uranium Metal

Total gamma activity from fission products and induced-activity radionuclides shall not exceed $0.3 \mu \mathrm{Ci} / \mathrm{g} \mathrm{U}$. The gamma activity from individual radionuclides shall not exceed the following:

\begin{tabular}{|l|c|}
\hline \multicolumn{1}{|c|}{ Radionuclide } & Maximum \\
\hline Cerium & $\boldsymbol{\mu a m m a}$ Activity \\
\hline Ruthenium & 0.05 \\
\hline Cesium & 0.05 \\
\hline Zirconium-Niobium-95 & 0.05 \\
\hline Any other individual radionuclide & 0.10 \\
\hline
\end{tabular}

\footnotetext{
${ }^{24}$ External Correspondence, "Proposed Y-12 Plant Specifications for Recycle Material Shipments and Receipts," G.G. Fee to J.L. Foutch, September 26, 1985.

${ }^{25}$ DOE-ORO Correspondence, "Proposed Y-12 Plant Specifications for Recycle Material Shipments and Receipts," J.L. Foutch to G.G. Fee, October 24, 1985.

${ }^{26}$ Egli et al., Report of the Joint Task Force on Uranium Recycle Materials Processing, 1985.
} 
As in the past, the rationale for the alpha specification is that it is intended to limit internal exposure from inhalation, which is monitored indirectly by bioassay and air sampling. These latter methods, as performed at the Y-12 Complex, do not monitor specifically for transuranics; consequently, a knowledge of the transuranic content of the uranium is important in the assessment of internal exposures.

\section{$1 \mathrm{dpm}$ transuranics \\ $1000 \mathrm{dpm}$ uranium}

The above specification was established to maintain the internal exposure potential of transuranics to a small percentage, i.e., $5 \%$ or less of the exposure potential of uranium. The potential hazard of the transuranics is related to the potential hazard of uranium by a comparison of their most restrictive (lowest) air concentration standards. Thus, keeping the transuranic isotopes activity at 1/1000 of the uranium activity would result in a potential exposure of 5 percent of the transuranic air standard at the level of the most restrictive uranium air standard.

$220 \mathrm{dpm} / \mathrm{m}^{3}$ (most restrictive uranium air standard) $\times 0.001=0.050$ or $5 \%$ $4.4 \mathrm{dpm} / \mathrm{m}^{3}$ (most restrictive transuranic isotope air limit)

The beta and gamma specifications were intended to keep external exposures as low as reasonably achievable, monitored directly by personnel dosimeters. The total beta activity includes beta exposure from the gamma-emitting isotopes as well as from pure beta emitters such as ${ }^{90} \mathrm{Sr}$ and ${ }^{99} \mathrm{Tc}$. Total gamma activity included both fission-product and inducedactivity radionuclides. Gamma activity maximum limit values were specified for individual isotopes, including cerium, ruthenium, cesium, zirconium-niobium-95, and others.

Collectively, they were not to exceed the total gamma activity limit stated.

The DOE-approved specifications could be exceeded on individual batches with notification and mutual agreement between shipper and receiver. The specifications applied only to shipments and receipts. Analyses of side and residue streams at the Y-12 Complex show that the processing of reactor returns concentrates the transuranic and fission-product radionuclides relative to the uranium as the uranium concentration becomes dilute.

\subsubsection{Y-12 Complex RU Sampling Program}

Written communications confirm the existence of a routine sampling program with analytical measurements for TRU and fission products in RU. Sampling supported the health physics program and material specifications. Internal correspondence documents the agreedupon schedule for analyses and sampling and the requested radiation surveys for designated locations at the SRS processing equipment. 27 The 1977 sampling schedule and frequency are as follows:

\footnotetext{
${ }^{27}$ Internal Correspondence, "Special Analysis and Sampling Plan," C.M. West to J.R. Barkman, February 18, 1977.
} 
Table 4.3-1 Sampling Schedule and Frequency for 1977

\begin{tabular}{|l|l|l|}
\multicolumn{1}{|c|}{ Stream } & \multicolumn{1}{c|}{ Sample Type } & \multicolumn{1}{c|}{ Sampling Frequency } \\
\hline SRS & Receipts & Every Other Shipment \\
\hline SRS & Raffinate & Quarterly \\
\hline SRS & Evaporator Product & Quarterly \\
\hline SRS & Residues & Annually \\
\hline SRS & Returns & One sample lot out of each two \\
\hline Regular & Metal from Teardown & Annually \\
\hline Regular & Metal from Recycle & Annually \\
\hline
\end{tabular}

Internal correspondence documents that additional samples were taken as needed to isolate and resolve problems resulting from the accumulation of radioactive species other than uranium in SRS operations. ${ }^{28}$ The analytical results for $\mathrm{Pu}, \mathrm{Np}$, Th, total alpha, ${ }^{95} \mathrm{Zr}-\mathrm{Nb}$, and ${ }^{106} \mathrm{Ru}$ in a number of Oralloy and SRS material streams are reported and compared to the Y-12 Complex Guideline.

In 1973 the Y-12 Complex Chemical Services found an increased transuranic disintegration rate to uranium disintegration rate in recovery process residues. They performed an extensive review of the components contributing to the chemical recovery materials streams relating directly to the introduction and/or concentration of fission products and other radioactive contaminants. A series of process residue batches, including SRS Oralloy-related residues, were sampled and analyzed for ${ }^{237} \mathrm{~Np},{ }^{238} \mathrm{Pu},{ }^{239} \mathrm{Pu},{ }^{239-240} \mathrm{Pu},{ }^{228} \mathrm{Th}$, ${ }^{241} \mathrm{Am},{ }^{137} \mathrm{Cs}$, and ${ }^{95} \mathrm{Zr}-\mathrm{Nb}$. Based upon the results, a closer look at the constituents in salvage materials was taken. After evaluating several possibilities for the introduction of transuranic contamination into the recovery process stream, such as material crossover, processing of returned weapons parts, cascade product, nitric acid leaching rate, and introduction at various points, they concluded that "the excessive concentration of radioactive contamination found in leached process residues is caused mainly by differences in their leaching rate with that of uranium."

A 1979 letter documents the continuation of efforts, in cooperation between Health Physics and Chemical Services Department, to sample and review results from the SRS streams, side streams, and regular streams, in order to help ensure that there were no unrecognized health physics problems. ${ }^{30}$ The results helped those involved to define the path of the impurities through the RU processing stream and to evaluate the concentration of the impurities found in various side streams against established limits. A review of 1977 and 1978 results are presented in the letter for receipts, shipments, and side streams, including secondary feed, raffinates, and residues. The data is presented in Section 4.5 of this report.

Internal correspondence from 1985 documents that "sampling of the recovery-process side streams was performed during RU processing at Y-12 Plant and results have shown that there is some concentration of contaminants in both liquid and solid-waste streams."

\footnotetext{
${ }^{28}$ Internal Correspondence, “Transuranics and Fission Products,” W.H. Tipton to J.R. Barkman, December 17, 1973.

${ }^{29}$ Internal Correspondence, "Contributions of Radiation in Salvage Materials," W.H. Tipton to J.R. Barkman, March 2, 1973.

${ }^{30}$ Internal Correspondence, "SRO Results,” C.M. West to J.R. Barkman, April 26, 1979.

${ }^{31}$ Internal Correspondence, "Radioactive Contaminants in Uranium Reactor Returns Processed at Y-12," J.B. Hunt to E. Owings, September 11, 1985.
} 
Operations and Health Physics staff routinely monitored SRS processing side streams and waste streams, including secondary feed, raffinates, and residues in liquid and solid phases, for both TRU and fission products.

Y-12 Complex Procedures provided instructions for receiving tankers from $S R S$ and weighing, transferring, sampling, and ensuring the return of empty containers. 32

Plant procedures also established a schedule for sampling and reporting fission product and transuranic impurities in enriched uranium materials. Those procedures described the materials to be sampled, frequency of sampling, the required analyses, and the distribution of results. ${ }^{33}$ Table 4.3-2 lists the established sampling frequency for radioisotope analysis.

Table 4.3-2 Sampling Frequency

\begin{tabular}{|c|c|c|}
\hline Material & Frequency & Sample Size \\
\hline UN Solution from Savannah River & Odd-numbered receipt & $100 \mathrm{ml}$ \\
\hline Oxide from Savannah River & Odd-numbered receipt & $5 \mathrm{~g}$ \\
\hline Savannah River Recycle Metal & Every 10th Batch & $2 \mathrm{~g}$ \\
\hline Idaho (ICPP) $\mathrm{UO}_{3}$ & Every Shipment & $5 \mathrm{~g}$ \\
\hline Idaho (ICPP) Recycle Metal & Every 10th Batch & $2 \mathrm{~g}$ \\
\hline Primary Castings from Rocky Flats Returns & Every 11th Batch & $2 \mathrm{~g}$ \\
\hline Castings from Metal Chips & Every 10th Pour & $2 \mathrm{~g}$ \\
\hline Off-site Reactor Recycle Salvage & Every Receipt & $500 \mathrm{ml} / 5 \mathrm{~g}$ \\
\hline Biodenitrification Sludge & Once per Month & $500 \mathrm{ml}$ \\
\hline $\mathrm{HNO}_{3}$ Still Distillate Discard & Once per Month & $500 \mathrm{ml}$ \\
\hline Aluminum Alloy Caustic Filtrate & Once per Month & $500 \mathrm{ml}$ \\
\hline
\end{tabular}

Internal documentation confirms that "every 805 can was sampled for uranium isotopics and chemical contaminants. Approximately every tenth can was sampled for Neptunium, Plutonium and fission/decay products. For quality assurance, laboratory results for ${ }^{235} \mathrm{U}$ assay could notyary by greater than 0.3 percent from the value calculated based on the $\mathrm{UF}_{4}$ mixing ratio."

The frequency and location of sampling for recovery-process regular and side streams were evaluated and modified throughout the processing campaigns to support specification verification and worker protection, as evidenced in internal correspondence between Health Physics and Chemical Processing. For example, "sampling frequency on SRO residues is changed from annual to quarterly.'

\subsubsection{Savannah River Specifications}

The specification for recycled enriched uranium from the Savannah River Site is denoted in several inter-DOE plant communications: as SRP-EMS-97 in a 1979 letter, EM specification 97 in a 1981 letter, and an 1988 photocopy (handwritten label). The limit,

\footnotetext{
${ }^{32}$ Martin Marietta Energy Systems, "Oak Ridge Y-12 Plant Procedures, SRP Receiving and Sampling," 50-3792-101, Chemical Services Department, February, 26, 1986.

${ }^{33}$ Martin Marietta Energy Systems, "Oak Ridge Y-12 Plant Procedures, Sampling Enriched Uranium for Fission Product and Transuranic Impurities," 50-37-EU-004, Metal Preparation Division, Enriched Uranium Operations Department, October 17, 1988.

${ }^{34}$ Lockheed Martin Energy Systems, "Grouping Uranium Metal Buttons for the Off-Specification Fuel Project," 1999.

${ }^{35}$ Internal Correspondence, "Special Analyses and Sampling Plan," C.M. West to A.R. Flynn, May 18, 1977.
} 
"total alpha activity from neptunium and plutonium shall not exceed $0.1 \mu \mathrm{Ci} / \mathrm{g} \mathrm{U}$ ", does not change over the nine-year period. The limit on technetium is not explicitly spelled out beyond the limits defined in Section 4.3.1. The gamma activity from individual radionuclides shall not exceed $0.05 \mu \mathrm{Ci} / \mathrm{g} U$ for any radionuclide other than cerium, ruthenium, cesium, or zirconium-niobium-95. This limit also remains unchanged over the nine-year period. The ${ }^{236} \mathrm{U}$ content was not specified for the recycled enriched uranium because it was determined by the supplier of the RU in solution form, namely SRS, which was the same as the customer for the metal product. Also, the presence of the ${ }^{236} \mathrm{U}$ in the recycled uranium was accounted for in the existing U limits at the Y-12 Complex and, presumably, at SRS.

Savannah River Site Essential Material Specifications documents (EM Specification 97 - Recycled Enriched Uranium, 110 - High Purity Oralloy, and 118 - Cast Oralloy, dated May 4, 1988) define the material; product inspection and analysis; process specifications; product specifications, including chemical impurities, isotopic concentration, radioactivity, and total gamma activity; packaging and shipping; and nuclear criticalityrequirements for material to be shipped to the Y-12 Complex from Savannah River Site. 16 These standards, as shown below, were revised and communicated over the processing years. 39

Internal correspondence documents Y-12 Complex receiptof Savannah River material and evaluation against Savannah River Acceptance Standards.

\begin{tabular}{|c|c|}
\hline \multicolumn{2}{|c|}{$\begin{array}{c}\text { PRODUCT SPECIFICATIONS (1988) } \\
\text { EM SPECIFICATION 97 - RECYCLED URANIUM } \\
\text { Recycled Enriched Uranium - Uranium metal produced from previously irradiated uranium. }\end{array}$} \\
\hline Minimum U Concentration & $99.5 \mathrm{wt} \%$ \\
\hline Isotopic Concentration & * \\
\hline Total Gamma Activity & $\leq 0.3 \mu \mathrm{Ci} / \mathrm{g} U$ \\
\hline Cerium & $\leq 0.05 \mu \mathrm{Ci} / \mathrm{g} \mathrm{U}$ \\
\hline Ruthenium & $\leq 0.05 \mu \mathrm{Ci} / \mathrm{g} \mathrm{U}$ \\
\hline Cesium & $\leq 0.05 \mu \mathrm{Ci} / \mathrm{g} \mathrm{U}$ \\
\hline Zirconium-Niobium-95 & $\leq 0.10 \mu \mathrm{Ci} / \mathrm{g} \mathrm{U}$ \\
\hline Any other radionuclide & $\leq 0.05 \mu \mathrm{Ci} / \mathrm{g} \mathrm{U}$ \\
\hline Total Alpha Activity & $\leq 0.1 \mu \mathrm{Ci} / \mathrm{g} \cup \quad$ (from Neptunium and Plutonium) \\
\hline
\end{tabular}

\footnotetext{
${ }^{36}$ Essential Material Specification 97: Recycled Enriched Uranium, Savannah River Complex; May 4, 1988.

${ }^{37}$ Essential Material Specification 110: High Purity Oralloy, Savannah River Plant; May 4, 1988.

${ }^{38}$ Essential Material Specification 118: Cast Oralloy, Savannah River Complex; May 4, 1988.

${ }^{39}$ Internal Correspondence, "Proposed Revision of SRP-EMS-110 High Purity Oralloy," F.C. Rhode to W.H. Tipton, January 29,1979.

${ }^{40}$ Internal Correspondence, "SRO Results,” C.M. West to J.R. Barkman, April 26, 1979.
} 


\begin{tabular}{|c|c|c|}
\hline \multicolumn{3}{|c|}{$\begin{array}{l}\text { PRODUCT SPECIFICATIONS (1988) } \\
\text { EM SPECIFICATION 110- HIGH PURITY ALLOY } \\
\text { High Purity Oralloy - enriched uranium metal produced by the reduction of UF } 4 \text { produced } \\
\text { from unirradiated reprocessed uranium from the } Y-12 \text { Complex and other sites. }\end{array}$} \\
\hline \multicolumn{2}{|l|}{ Minimum U Concentration } & 99.5 wt \% \\
\hline \multirow[t]{4}{*}{ Isotopic Concentration } & ${ }^{234} \mathrm{U}$ & 1.25 wt \% maximum \\
\hline & ${ }^{235} \mathrm{U}$ & 93.0 wt \% maximum \\
\hline & ${ }^{236} \mathrm{U}$ & 0.75 wt $\%$ maximum \\
\hline & ${ }^{238} \mathrm{U}$ & 6.00 wt $\%$ maximum \\
\hline \multicolumn{2}{|l|}{ Total Gamma Activity } & $\leq 0.3 \mu \mathrm{Ci} / \mathrm{g} \mathrm{U}$ \\
\hline \multicolumn{2}{|l|}{ Cerium } & $\leq 0.05 \mu \mathrm{Ci} / \mathrm{g} \mathrm{U}$ \\
\hline \multicolumn{2}{|l|}{ Ruthenium } & $\leq 0.05 \mu \mathrm{Ci} / \mathrm{g} \mathrm{U}$ \\
\hline \multicolumn{2}{|l|}{ Cesium } & $\leq 0.05 \mu \mathrm{Ci} / \mathrm{g} \mathrm{U}$ \\
\hline \multicolumn{2}{|l|}{ Zirconium-Niobium-95 } & $\leq 0.10 \mu \mathrm{Ci} / \mathrm{g} \mathrm{U}$ \\
\hline \multicolumn{2}{|l|}{ Any other radionuclide } & $\leq 0.05 \mu \mathrm{Ci} / \mathrm{g} \mathrm{U}$ \\
\hline \multicolumn{2}{|l|}{ Total Alpha Activity } & $\leq 0.1 \mu \mathrm{Ci} / \mathrm{g} \cup \quad$ (from Neptunium and Plutonium) \\
\hline
\end{tabular}

\begin{tabular}{|c|c|c|}
\hline \multicolumn{3}{|c|}{$\begin{array}{c}\text { PRODUCT SPECIFICATIONS (1988) } \\
\text { EM SPECIFICATION } 118 \text { - CAST ORALLOY } \\
\text { Cast Oralloy - enriched uranium metal produced by melting and casting } \\
\text { weapons grade Oralloy metal and scrap. }\end{array}$} \\
\hline \multicolumn{2}{|c|}{ Minimum U Concentration } & 99.5 wt \% \\
\hline \multirow[t]{4}{*}{ Isotopic Concentration } & ${ }^{234} \mathrm{U}$ & 1.25 wt $\%$ maximum \\
\hline & ${ }^{235} \mathrm{U}$ & 93.0 wt \% maximum \\
\hline & ${ }^{236} U$ & 0.75 wt $\%$ maximum \\
\hline & ${ }^{238} \mathrm{U}$ & 6.00 wt $\%$ maximum \\
\hline \multicolumn{2}{|l|}{ Total Gamma Activity } & $\leq 0.3 \mu \mathrm{Ci} / \mathrm{g} U$ \\
\hline \multicolumn{2}{|l|}{ Cerium } & $\leq 0.05 \mu \mathrm{Ci} / \mathrm{g} \mathrm{U}$ \\
\hline \multicolumn{2}{|l|}{ Ruthenium } & $\leq 0.05 \mu \mathrm{Ci} / \mathrm{g} \mathrm{U}$ \\
\hline \multicolumn{2}{|l|}{ Cesium } & $\leq 0.05 \mu \mathrm{Ci} / \mathrm{g} \mathrm{U}$ \\
\hline \multicolumn{2}{|l|}{ Zirconium-Niobium-95 } & $\leq 0.10 \mu \mathrm{Ci} / \mathrm{g} \mathrm{U}$ \\
\hline \multicolumn{2}{|l|}{ Any other radionuclide } & $\leq 0.05 \mu \mathrm{Ci} / \mathrm{g} \mathrm{U}$ \\
\hline \multicolumn{2}{|l|}{ Total Alpha Activity } & $\leq 0.1 \mu \mathrm{Ci} / \mathrm{g} \cup \quad$ (from Neptunium and Plutonium) \\
\hline
\end{tabular}

The Oak Ridge Y-12 Plant/Savannah River Site Shipping Agreement Plan, October 1986, approved by Y-12 Complex, DOE-ORO, and DOE-SRS, documents the written agreement for ${ }^{235} \mathrm{U}$ shipments between the Savannah River Site and the Y-12 Complex. The agreement specifies method of shipment, information and analytical data to accompany each shipment, accountability determination, sampling protocol, analytical methods, accepted precision of methods, packaging, and resolution of shipper/receiver differences.

${ }^{41}$ Oak Ridge Y-12 Plant - Savannah River Plant, Shipping Agreement Plan, October 1986. 


\subsection{ANALYTICAL RESULTS FOR TRU ELEMENTS AND FISSION PRODUCTS IN RECYCLED URANIUM MATERIALS RECEIVED AT THE Y-12 COMPLEX}

From the beginning, the presence of non-uranium constituents in RU receipts and the introduction of these TRU and fission product constituents into the Y-12 Complex facilities and equipment as a result of processing those receipts were recognized. Evidence indicates $\mathrm{RU}$ that was to be shipped to or was received at the Y-12 Complex was systematically sampled, with checks performed for TRU and fission products. Records of analytical data for receipts were found in a number of incidental files that still exist at the Y-12 Complex. These records consisted of

- correspondence between the Y-12 Complex, DOE-ORO, and the shipper sites documenting agreement on specifications regarding TRU and fission products,

- copies of some laboratory analysis reports,

- summary Uranium Radioactivities Reports prepared by the RADCON department manager and informal notes showing calculations used in preparing summary reports, and

- copies of sampling and analysis protocols used.

\subsubsection{Recycled Enriched Uranium from the Savannah River Site (SRS)}

RU from SRS was processed at the Y-12 Complex by solvent extraction purification of impure uranyl nitrate solution, evaporation, denitration by thermal decomposition to $\mathrm{UO}_{3}$, hydrogen reduction to $\mathrm{UO}_{2}$, hydrofluorination to $\mathrm{UF}_{4}$, and bomb reduction to produce uranium metal buttons. SRS shipped RU to the Y-12 Complex in the form of uranyl nitrate solution, U-Al alloy scrap, and casting dross and furnace sweepings from the SRS U-Al alloying process.

\subsubsection{SRS Uranyl Nitrate Solutions}

Laboratory analysis results reports were found for 69 samples of concentrated uranyl nitrate solution (material type 1443) receipts from SRS from the period 1984 through 1986. Of these, 10 results were from material received in 1984, 43 results were from material received in 1985, and 16 results were from material received in 1986. These results were found in the retained files of a retired health physicist who prepared the annual summary of uranium radioactivities reports and were located with copies of those summary reports, including those for the years 1984 through 1986. Analytical data for the 69 samples identified as material type 1443 are summarized in Table 4.4-1. 
Table 4.4-1 Analytical Data for Uranyl Nitrate Solution Receipts from Savannah River Site during the 1984 - 1986 Time Period

\begin{tabular}{|c|c|c|c|c|c|}
\hline SRS 14431984 to 1986 & Valid $\mathbf{N}$ & Mean & Minimum & Maximum & Std. Dev. \\
\hline${ }^{237} \mathrm{~Np} \mu \mathrm{Ci} / \mathrm{g} U$ & 69 & 0.0246942 & 0.002 & 0.11814 & 0.0279664 \\
\hline Total TRU dpm/g U & 17 & 29339.353 & 5000.000 & 69500.000 & 18595.811 \\
\hline${ }^{238-40} \mathrm{Pu} \mu \mathrm{Ci} / \mathrm{g} \mathrm{U}$ & 69 & 0.0041928 & 0.001 & 0.03400 & 0.0063449 \\
\hline${ }^{228} \mathrm{Th} \mu \mathrm{Ci} / \mathrm{g} \mathrm{U}$ & 67 & 0.0316728 & 0.005 & 0.13728 & 0.0381396 \\
\hline Total Actinides $\mu \mathrm{Ci} / \mathrm{g} U$ & 51 & 0.0366667 & 0.009 & 0.20000 & 0.0319322 \\
\hline Alpha Ratio & 68 & 0.2848676 & 0.001 & 1.33000 & 0.2542608 \\
\hline${ }^{137} \mathrm{Cs} \mu \mathrm{Ci} / \mathrm{g} U$ & 68 & 0.0010000 & 0.001 & 0.00100 & 0 \\
\hline${ }^{95} \mathrm{Zr}-\mathrm{Nb} \mu \mathrm{Ci} / \mathrm{g} \mathrm{U}$ & 69 & 0.1836377 & 0.019 & 0.89700 & 0.169685 \\
\hline${ }^{106} \mathrm{Ru} \mu \mathrm{Ci} / \mathrm{g} \mathrm{U}$ & 69 & 0.1170290 & 0.001 & 1.58000 & 0.1846213 \\
\hline${ }^{144} \mathrm{Ce} \mu \mathrm{Ci} / \mathrm{g} \mathrm{U}$ & 17 & 0.0010000 & 0.001 & 0.00100 & 0 \\
\hline${ }^{232} \mathrm{U} \mu \mathrm{Ci} / \mathrm{g} U$ & 52 & 0.5848269 & 0.363 & 4.21200 & 0.5165707 \\
\hline 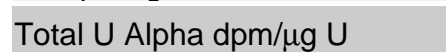 & 68 & 218.0226500 & 196.110 & 230.22000 & 10.1364970 \\
\hline$\%{ }^{233} \mathrm{U}$ & 54 & 0.0100000 & 0.010 & 0.01000 & 0 \\
\hline$\%^{234} \mathrm{U}$ & 69 & 1.2784058 & 1.200 & 1.32000 & 0.0308518 \\
\hline$\%{ }^{235} \mathrm{U}$ & 69 & 52.2136230 & 46.190 & 66.54000 & 6.4555897 \\
\hline$\%{ }^{236} \mathrm{U}$ & 69 & 29.2359420 & 19.290 & 33.85000 & 4.7662374 \\
\hline$\%{ }^{238} U$ & 69 & 17.2498550 & 12.950 & 19.45000 & 1.7361396 \\
\hline Beta Ratio & 69 & 1.0438696 & 0.234 & 1.40700 & 0.2430715 \\
\hline
\end{tabular}

The time distribution of $\mathrm{Pu}$ and $\mathrm{Np}$ values is shown in Figures 4.4-1 and 4.4-2. For this data set, and during the period October 1984 through October 1986, Pu results ranged from $<0.001$ to $0.034 \mu \mathrm{Ci} / \mathrm{g} \mathrm{U}$ with an average Pu value of $0.004 \mu \mathrm{Ci} / \mathrm{g} \mathrm{U}$. Np results ranged from 0.002 to $0.11814 \mu \mathrm{Ci} / \mathrm{g} \mathrm{U}$ with an average $\mathrm{Np}$ value of $0.02469 \mu \mathrm{Ci} / \mathrm{g} \mathrm{U}$. The ${ }^{236} \mathrm{U}$ ranged from 19.29 to $33.85 \mathrm{wt} \% \mathrm{U}$ and ${ }^{235} \mathrm{U}$ ranged from 46.19 to $66.54 \mathrm{wt} \% \mathrm{U}$.

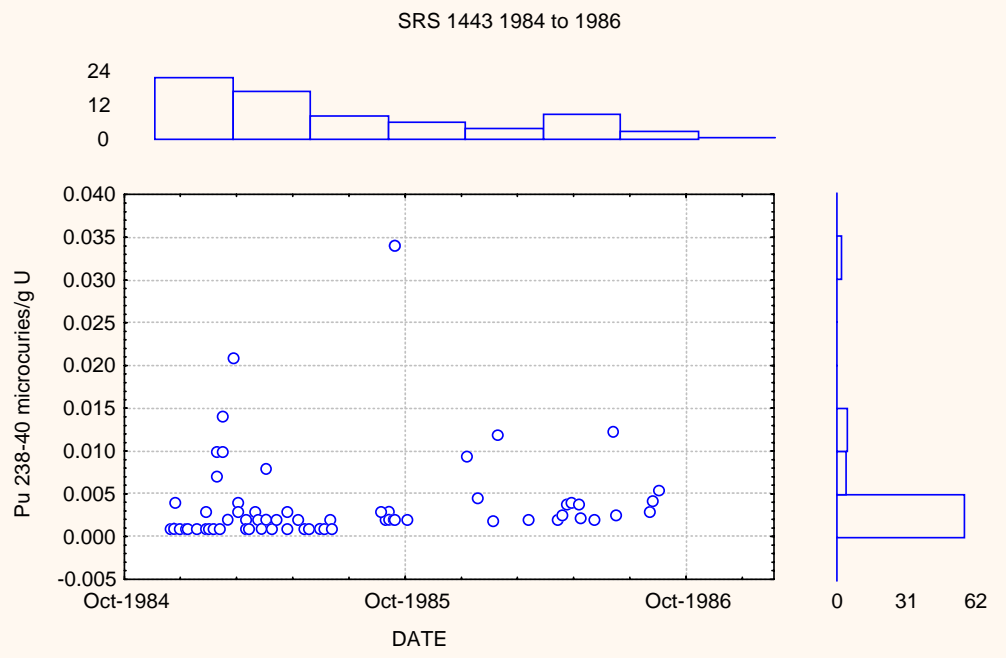

Fig. 4.4-1 Pu in Uranyl Nitrate Solutions from Savannah River. 


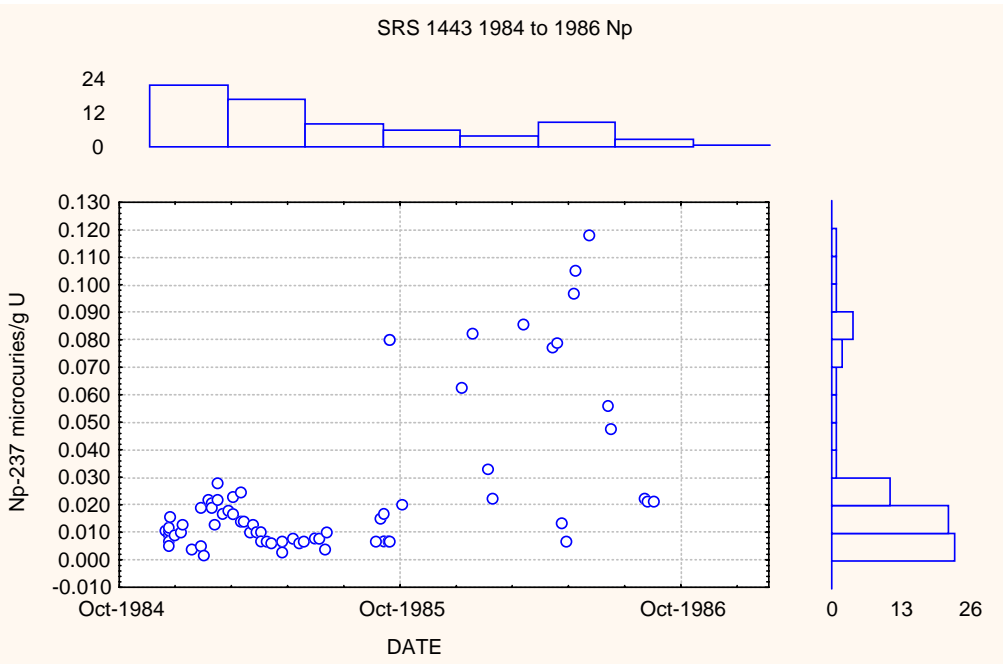

Fig. 4.4-2 $\mathrm{Np}$ in Uranyl Nitrate Solutions from Savannah River.

The relationship of ${ }^{235} \mathrm{U}$ and ${ }^{236} \mathrm{U}$ is shown in Figure 4.4-3, and the time distribution of ${ }^{236} \mathrm{U}$ is shown in Figure 4.4-4. For the purposes of performing de minimis calculations for the material represented by this sample population, the data show maximum, minimum, and average cases with respect to ${ }^{236} \mathrm{U}$ as follows:

$\begin{array}{ll}\text { Maximum }{ }^{236} \mathrm{U} \text { Case: } & 33.84 \mathrm{wt} \%{ }^{236} \mathrm{U} \text { and } 46.19 \mathrm{wt} \%{ }^{235} \mathrm{U} \\ \text { Minimum }{ }^{236} \mathrm{U} \text { Case: } & 19.29 \mathrm{wt} \%{ }^{236} \mathrm{U} \text { and } 66.54 \mathrm{wt} \%{ }^{235} \mathrm{U} \\ \text { Average }{ }^{236} \mathrm{U} \text { Case: } & 29.24 \mathrm{wt} \%{ }^{236} \mathrm{U} \text { and } 52.21 \mathrm{wt} \%{ }^{235} \mathrm{U}\end{array}$

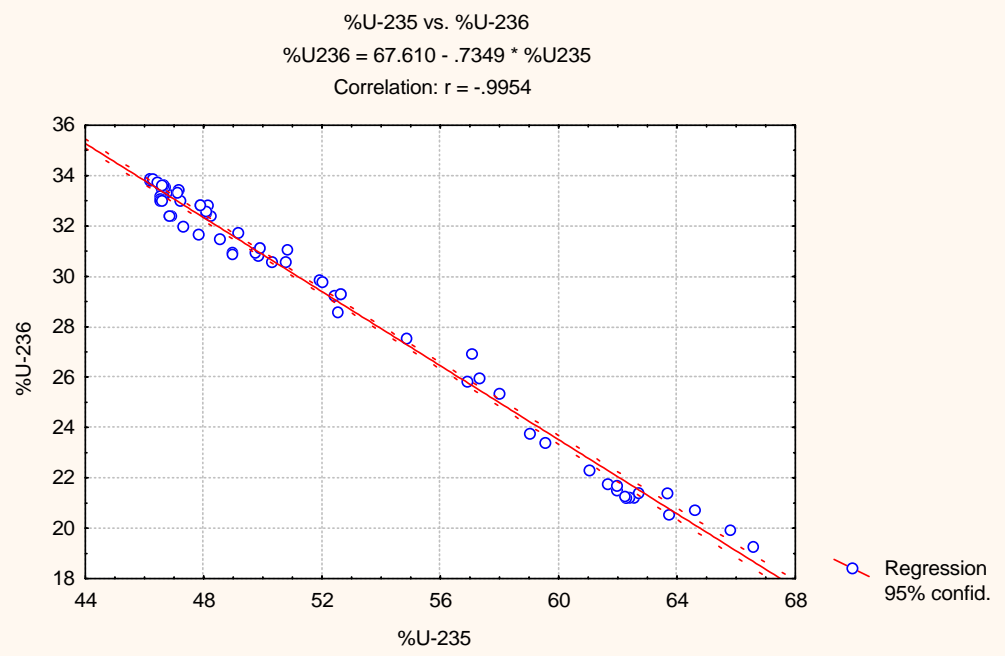

Fig. 4.4-3 Relationship of ${ }^{235} U$ and ${ }^{236} U$ in Uranyl Nitrate Solutions from Savannah River. 


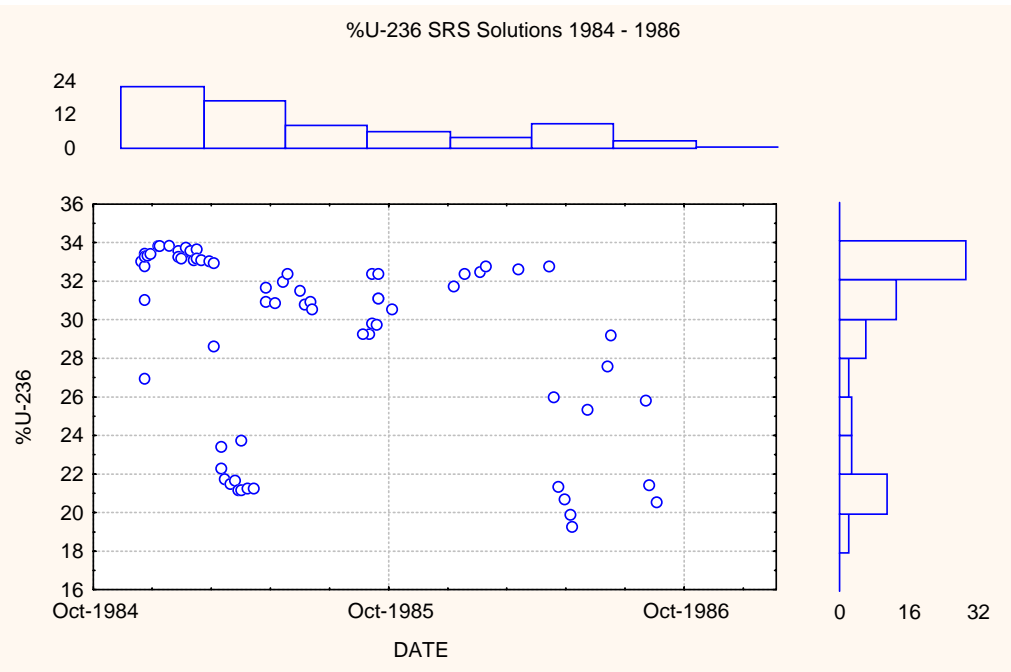

Fig. 4.4-4 ${ }^{236} \mathrm{U}$ in Uranyl Nitrate Solutions from Savannah River.

The time distributions of alpha and beta ratios for this data set are shown in Figures 4.4-5 and 4.4-6 respectively. Several of the samples in this data set exceeded the alpha ratio specification limit of 1.0. Solving the alpha ratio for the maximum combined activity of non-uranium actinides gives a specification limit of $0.1 \mu \mathrm{Ci} / \mathrm{g} \mathrm{U}$.

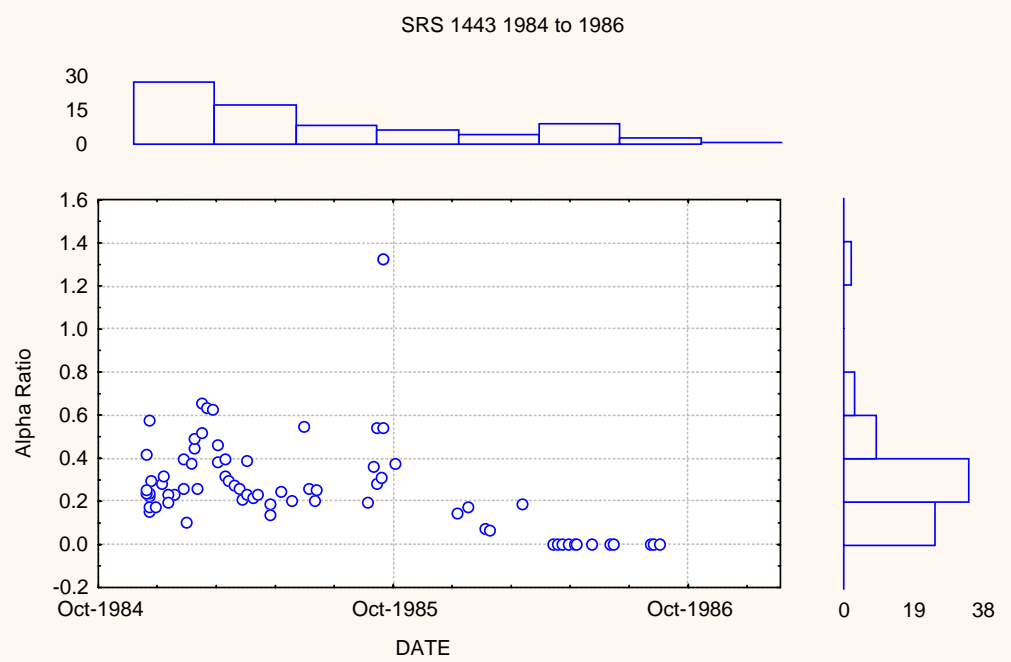

Fig. 4.4-5 Alpha Ratio for Uranyl Nitrate Solutions from Savannah River. 


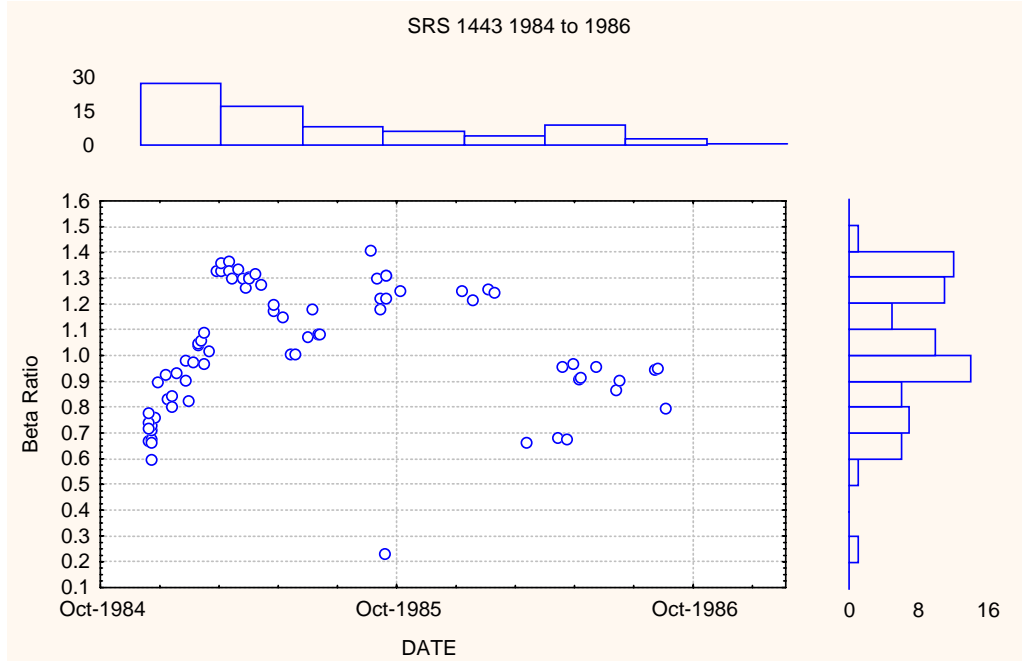

Fig. 4.4-6 Beta Ratio for Uranyl Nitrate Solutions from Savannah River.

The constituency of those samples exceeding the specification limit of $0.1 \mu \mathrm{Ci} / \mathrm{g} \mathrm{U}$ is illustrated in Figure 4.4-7 showing the combined $\mathrm{Np}, \mathrm{Pu}$, and Th values.

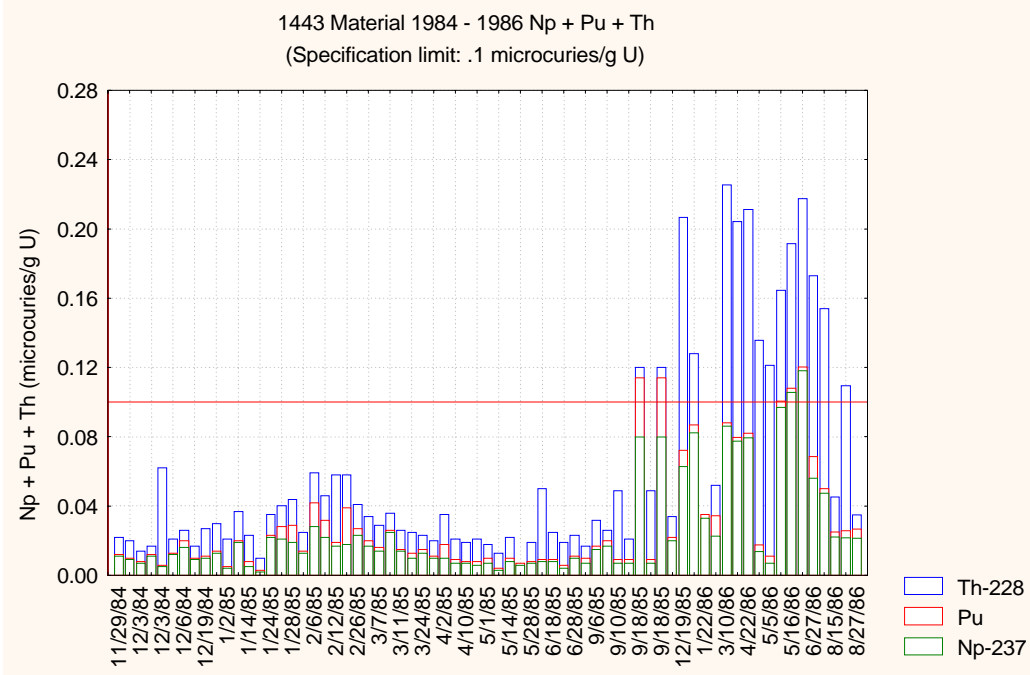

Fig. 4.4-7 Combined Values of $\mathrm{Np}$, $\mathrm{Pu}$, and $\mathrm{Th}$ in Solutions from Savannah River.

In addition to the 69 analytical results reports labeled as material type 1443, there were in the same file five analytical results reports labeled as material type 1420 (metal). The sample identifications are series 805-00-XXXX, which indicates they were metal product button batches made from SRS material. Also, the sample identification numbers increase by 
an increment of ten, which is consistent with the practice of sampling every tenth product batch for additional analysis for TRU and fission products. Three of the samples are dated November 29, 1984, and two are dated December 27, 1984. Analytical data for these metal product batches is summarized and discussed in Section 4.8.1.

Laboratory customer reports used to prepare the annual summary of uranium radioactivities reports for the period 1977 through 1983 were found in the retained files of the retired health physicist who prepared the annual summary report. The data from the laboratory customer reports is summarized in Table 4.4-2. Average values by calendar year are summarized in Table 4.4-3.

Table 4.4-2 Analytical Data for Solutions from Savannah River

\begin{tabular}{|c|c|c|c|c|c|}
\hline SRS UN SIn Receipts 1977 - 1983 & Valid N & Mean & Minimum & Maximum & Std. Dev. \\
\hline${ }^{237} \mathrm{~Np} \mu \mathrm{Ci} / \mathrm{g} \mathrm{U}$ & 157 & 0.0097643 & 0.001 & 0.074 & 0.0114114 \\
\hline${ }^{238-40} \mathrm{Pu} \mu \mathrm{Ci} / \mathrm{g} \mathrm{U}$ & 157 & 0.0036879 & 0.001 & 0.063 & 0.0076325 \\
\hline${ }^{228} \mathrm{Th} \mu \mathrm{Ci} / \mathrm{g} \mathrm{U}$ & 156 & 0.0121410 & 0.001 & 0.059 & 0.0081228 \\
\hline Total Actinides $\mu \mathrm{Ci} / \mathrm{g} \mathrm{U}$ & 156 & 0.0256090 & 0.007 & 0.117 & 0.0174136 \\
\hline Alpha Ratio & 156 & 0.2535449 & 0.019 & 0.757 & 0.1266563 \\
\hline Beta Ratio & 156 & 0.9496795 & 0.600 & 1.270 & 0.1157358 \\
\hline
\end{tabular}

Table 4.4-3 Average Value for Solutions from Savannah River

\begin{tabular}{|c|c|c|c|c|c|c|c|}
\hline $\begin{array}{c}1443 \text { Material } \\
\text { Average Values }\end{array}$ & 1977 & 1978 & 1979 & 1980 & 1981 & 1982 & 1983 \\
\hline${ }^{237} \mathrm{~Np} \mu \mathrm{Ci} / \mathrm{g} U$ & 0.0348824 & 0.006500 & 0.0121429 & 0.0060000 & 0.0083462 & 0.0039688 & 0.0058250 \\
\hline${ }^{238,240} \mathrm{Pu} \mu \mathrm{Ci} / \mathrm{g} U$ & 0.0137059 & 0.002500 & 0.0031429 & 0.0012308 & 0.0042308 & 0.0017813 & 0.0016250 \\
\hline${ }^{228} \mathrm{Th} \mu \mathrm{Ci} / \mathrm{g} \mathrm{U}$ & 0.0084706 & 0.009750 & 0.0091429 & 0.0077692 & 0.0086538 & 0.0125938 & 0.0187949 \\
\hline $\begin{array}{l}\text { Total Actinides } \\
\mu \mathrm{Ci} / \mathrm{g} \cup\end{array}$ & 0.0569412 & 0.018500 & 0.0243571 & 0.0148462 & 0.0212692 & 0.0182813 & 0.0263333 \\
\hline Alpha Ratio & 0.3587647 & 0.184875 & 0.2685714 & 0.1676923 & 0.2353846 & 0.2034688 & 0.2928462 \\
\hline Beta Ratio & 1.0788235 & 1.018750 & 1.0478571 & 0.9984615 & 0.9850000 & 0.9001250 & 0.8441026 \\
\hline
\end{tabular}

The alpha ratios as distributed by fiscal year are shown in Figure 4.4-8. Several samples in this data set exceeded the $0.1 \mu \mathrm{Ci} / \mathrm{g} \mathrm{U}$ limit for the combined activity of non-uranium alpha emitters. The constituency of those samples exceeding the specification limit of $0.1 \mu \mathrm{Ci} / \mathrm{g} \mathrm{U}$ is illustrated in Figure 4.4-9 showing the combined $\mathrm{Np}, \mathrm{Pu}$, and Th values for this data set. The beta ratios as distributed by fiscal year are shown in Figure 4.4-10; as can be seen, a few of the samples exceeded the beta ratio specification limit of 1.25. 


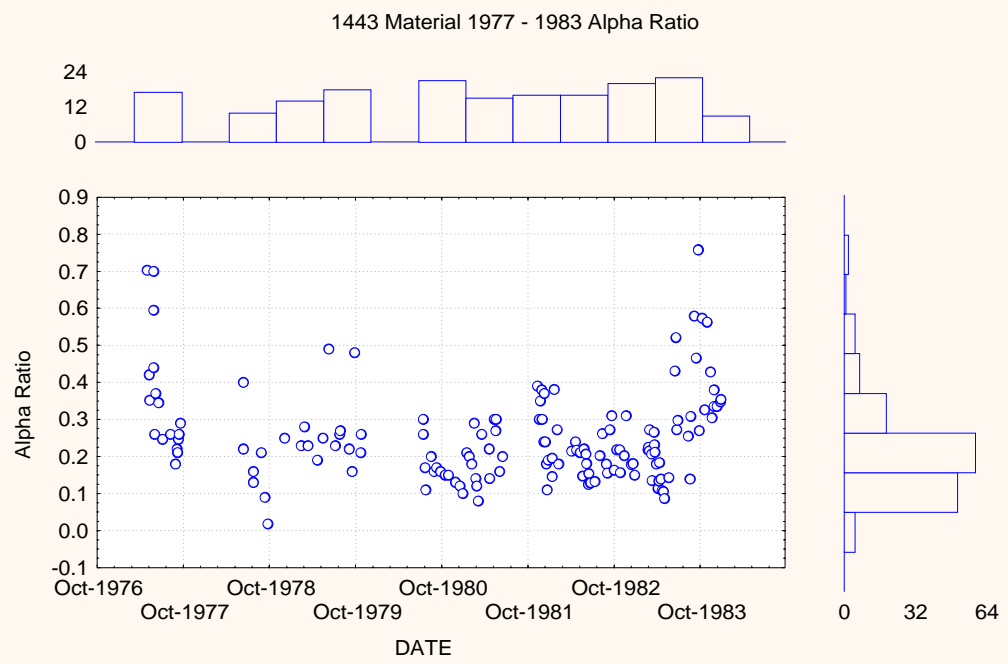

Fig. 4.4-8 Alpha Ratio in Solutions from Savannah River 1977 - 1983.

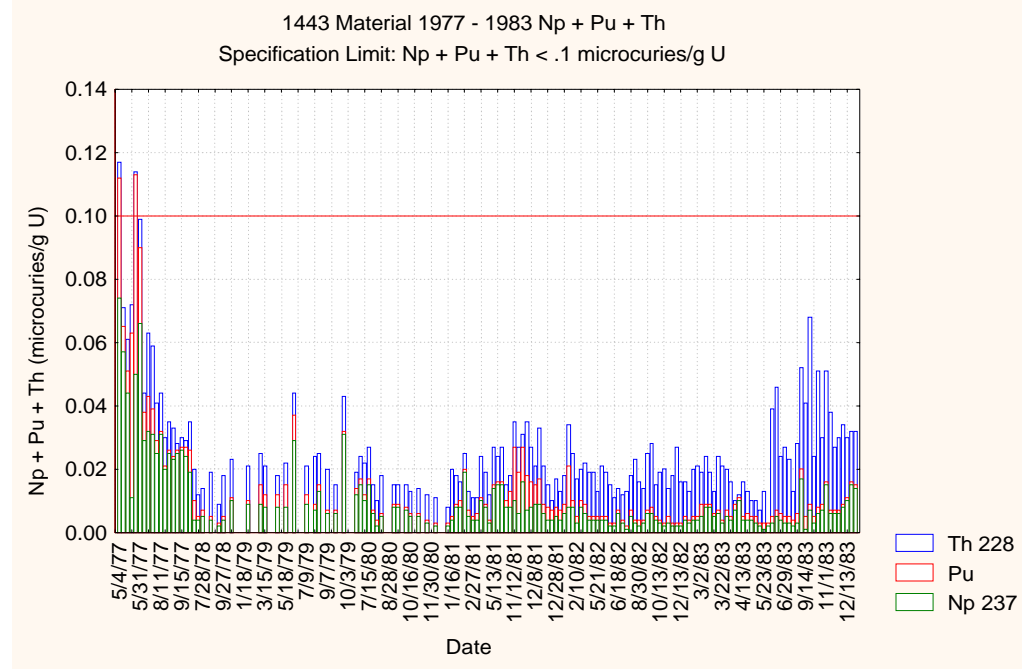

Fig. 4.4-9 Combined Values of $\mathrm{Np}, \mathrm{Pu}$, and Th in Solutions from Savannah River 1977 - 1983. 


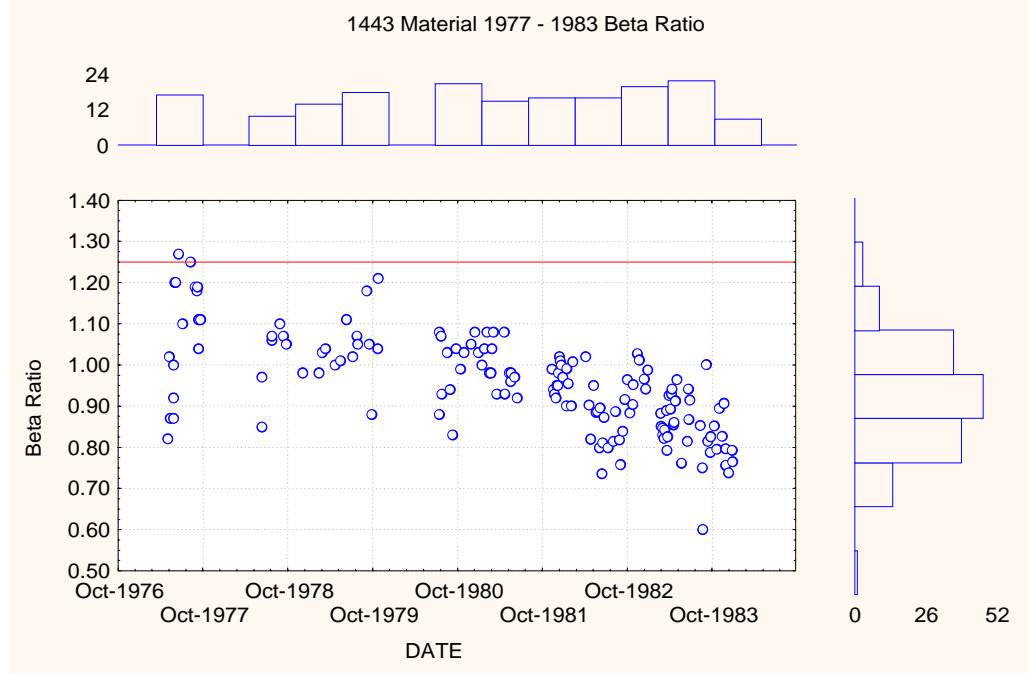

Fig. 4.4-10 Beta Ratio in Solutions from Savannah River 1977 - 1983.

Information on analytical results for samples of SRS uranyl nitrate solution shipments received in 1982 through 1984 was found. The information consisted of a handwritten spreadsheet, maintained by J.E. Vath, on which analytical data for 57 shipments had been transcribed. The data are summarized in Table 4.4-4.

Table 4.4-4 Analytical Data for Solutions from Savannah River 1982 - 1984

\begin{tabular}{|c|c|c|c|c|c|}
\hline $\begin{array}{c}\text { SRS UN Solution Receipts } \\
\mathbf{1 9 8 2}-\mathbf{1 9 8 4}\end{array}$ & Valid N & Mean & Minimum & Maximum & Std. Dev. \\
\hline${ }^{237} \mathrm{~Np} \mu \mathrm{Ci} / \mathrm{gU}$ & 57 & 0.0106316 & 0.001 & 0.072 & 0.0135550 \\
\hline${ }^{238-40} \mathrm{Pu} \mu \mathrm{Ci} / \mathrm{gU}$ & 57 & 0.0015965 & 0.001 & 0.006 & 0.0009423 \\
\hline${ }^{228} \mathrm{Th} \mu \mathrm{Ci} / \mathrm{gU}$ & 57 & 0.0197018 & 0.001 & 0.059 & 0.0098723 \\
\hline${ }^{137} \mathrm{Cs} \mu \mathrm{Ci} / \mathrm{gU}$ & 56 & 0.0010000 & 0.001 & 0.001 & 0 \\
\hline${ }^{95} \mathrm{Zr}-\mathrm{Nb} \mu \mathrm{Ci} / \mathrm{gU}$ & 57 & 0.0130000 & 0.001 & 0.040 & 0.0089662 \\
\hline${ }^{106} \mathrm{Ru} \mu \mathrm{Ci} / \mathrm{gU}$ & 57 & 0.1112281 & 0.001 & 0.238 & 0.0535410 \\
\hline${ }^{232} \mathrm{U} \mu \mathrm{Ci} / \mathrm{gU}$ & 57 & 0.5368947 & 0.305 & 0.838 & 0.1143600 \\
\hline${ }^{232} \mathrm{ppm}$ & 57 & 0.0257018 & 0.015 & 0.040 & 0.0055484 \\
\hline$\%{ }^{234} \mathrm{U}$ & 53 & 1.3292453 & 1.250 & 1.400 & 0.0324541 \\
\hline$\%{ }^{235} \mathrm{U}$ & 53 & 53.1033960 & 43.600 & 64.600 & 7.4250716 \\
\hline$\%{ }^{236} \mathrm{U}$ & 53 & 29.7720750 & 22.020 & 36.060 & 4.9520366 \\
\hline$\%{ }^{238} \mathrm{U}$ & 53 & 15.8600000 & 12.130 & 19.210 & 2.5480724 \\
\hline
\end{tabular}

For this data set, spanning 1982 to 1984 , Pu results ranged from 0.001 to $0.006 \mu \mathrm{Ci} / \mathrm{g} \mathrm{U}$ with an average $\mathrm{Pu}$ value of $0.002 \mu \mathrm{Ci} / \mathrm{g} \mathrm{U}$. Np results ranged from 0.001 to $0.072 \mu \mathrm{Ci} / \mathrm{g} \mathrm{U}$ with an average $\mathrm{Np}$ value of $0.012 \mu \mathrm{Ci} / \mathrm{g} \mathrm{U}$. As can be seen in Figure 4.4-11, the combination of $\mathrm{Np}$ and $\mathrm{Pu}$ did not exceed, and in most cases was an order of magnitude less than, the specification limit of $0.1 \mu \mathrm{Ci} / \mathrm{g} \mathrm{U}$. 
Figure 4.4-12 shows $\%{ }^{236} U$ for the uranyl nitrate solution shipments. For the material represented by this sample population, the data show maximum, minimum, and average cases with respect to $\%{ }^{236} \mathrm{U}$ as follows:

$\begin{array}{ll}\text { Maximum }{ }^{236} \mathrm{U} \text { Case: } & 36.06 \mathrm{wt} \%{ }^{236} \mathrm{U} \text { and } 43.6 \mathrm{wt} \%{ }^{235} \mathrm{U} \\ \text { Minimum }{ }^{236} \mathrm{U} \text { Case: } & 22.02 \mathrm{wt} \%{ }^{236} \mathrm{U} \text { and } 64.6 \mathrm{wt} \%{ }^{235} \mathrm{U} \\ \text { Average }{ }^{236} \mathrm{U} \text { Case: } & 29.77 \mathrm{wt} \%{ }^{236} \mathrm{U} \text { and } 53.10 \mathrm{wt} \%{ }^{235} \mathrm{U}\end{array}$

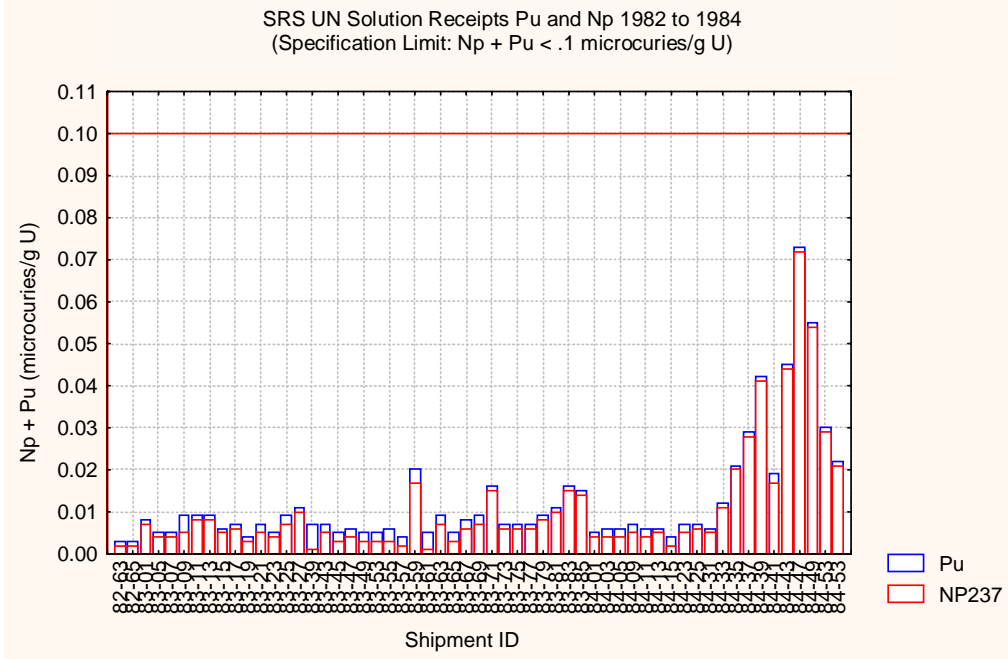

Fig. 4.4-11 Combined Values of $\mathrm{Np}$ and $\mathrm{Pu}$ in Savannah River Solutions 1982 - 1984.

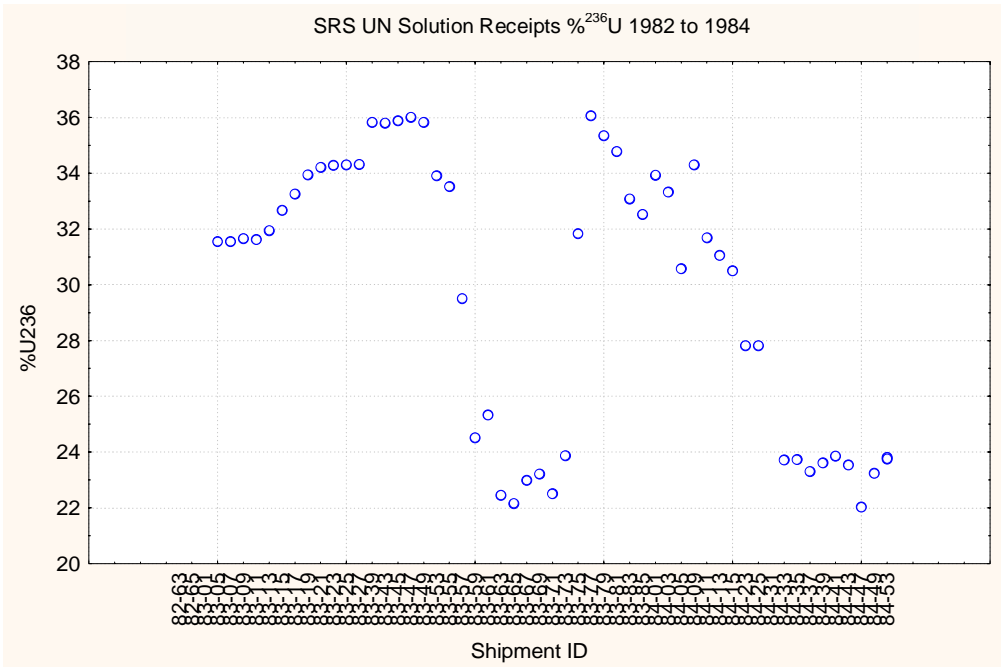

Fig. 4.4-12 ${ }^{236} \mathrm{U}$ in Solutions from Savannah River 1982 to 1984. 


\subsubsection{SRS Uranium-Aluminum Alloy Receipts}

In addition to uranyl nitrate solution, SRS also shipped RU to the Y-12 Complex in the form of uranium-aluminum (U-Al) alloy scrap and casting dross. The U-Al ingots were made at SRS using the uranium metal buttons produced at the Y-12 Complex from SRS and ICPP RU material. At SRS, the metal blending and alloying process produced the U-Al alloy used for fuel fabrication, along with casting dross and scrap shipped to the Y-12 Complex for uranium recovery processing. At the Y-12 Complex, the U-Al was processed by $\mathrm{NaOH}$ dissolution to remove the aluminum, leaving sodium diuranate solids. Nitric acid dissolution of sodium diuranate yielded impure uranyl nitrate solution, which was then purified, converted to metal, and returned to SRS. Table 4.4-5 summarizes results of uranium isotope analysis for 1,865 batches of U-Al scrap metal.

Table 4.4-5 U Isotopes in U-AI Alloy Scrap

\begin{tabular}{|c|c|c|r|r|r|}
\hline SRS U-Al Metal Alloy & Valid N & \multicolumn{1}{|c|}{ Mean } & Minimum & Maximum & Std. Dev. \\
\hline$\%^{234} \mathrm{U}$ & 1,865 & 1.181792 & 0.857664 & 1.38226 & 0.029010 \\
\hline$\%^{235} \mathrm{U}$ & 1,865 & 65.456200 & 51.418280 & 79.80500 & 1.772450 \\
\hline$\%^{236} \mathrm{U}$ & 1,865 & 19.915560 & 8.257000 & 31.40882 & 1.348041 \\
\hline$\%^{238} \mathrm{U}$ & 1,865 & 13.445030 & 10.899000 & 24.10546 & 0.580628 \\
\hline
\end{tabular}

\subsubsection{SRS Data for Period 1965 through 1972}

Additional historical information and analytical data for the period 1965 through 1972 was received from Y-12 Complex operations just prior to the issuance of this report. The information included a 1962 summary description of the ${ }^{237} \mathrm{~Np}$ recovery process for shipments of dilute uranyl nitrate from SRS, ${ }^{22}$ communications of radiological protection safety measures, and early years of analysis results for transuranics in SRS material, including concentration data on ${ }^{232} \mathrm{U},{ }^{239-240} \mathrm{Pu},{ }^{238} \mathrm{Pu},{ }^{237} \mathrm{~Np}$ and ${ }^{228} \mathrm{Th}$ for the period 1965 through 1972. The information provided confirms process information already incorporated into this report and health physics worker protection program measures in place for operations personnel. It is believed that this concentration data supports the C. M. West yearly summary data discussed in Section 5.1.2. Time did not permit additional analysis for this report.

\subsubsection{Recycled Uranium from the Idaho Chemical Processing Plant (ICPP)}

The ICPP began reprocessing spent nuclear fuel in February 1953. The plant was designed to process only highly enriched fuels. During its operating history, most of the

\footnotetext{
${ }^{42}$ Internal Correspondence, "Np-237 Operations," R.E. Trent to J.R. Barkman, April 5,1962.

${ }^{43}$ Internal Correspondence, "Safety Measures for Np-237 Processing," J.S. Reece to J.R. Barkman, September 9, 1960.

44 Internal Correspondence, "Trans-Uranium Elements in SRO Material," R.H. Kent to J.R. Barkman, December 7, 1964.
} 
uranium product was shipped to the Y-12 Complex. The ICPP was originally a reduction oxidation plant which utilized three cycles of methyl isobutyl ketone (hexone) extraction in packed columns. The fuels processed during that time period were unclad uranium slugs from production reactors at Hanford or Savannah River, unclad breeder reactor fuel from EBR-I, or aluminum clad fuels from Oak Ridge, the National Reactor Testing Station (NRTS), or Savannah River. A new higher capacity single plutonium/uranium extraction cycle using tributyl phosphate (TBP) in pulsed columns started up in August 1957 and operated in conjunction with two cycles of hexone until April of 1992. From 1953 until 1971, the uranium product produced at the ICPP was shipped as a concentrated uranyl nitrate $\left[\mathrm{UO}_{2}\left(\mathrm{NO}_{3}\right)_{2}\right]$ solytion. Subsequent to 1971 , the product was shipped as solid uranium trioxide $\left(\mathrm{UO}_{3}\right) .45$ The Y-12 Complex received shipments of ICPP RU from 1953 until 1986.

Historical information regarding eight receipts from Idaho for the period from 1964 through early 1966 was received from Y-12 Complex operations just prior to the issuance of this report. The information, as presented in Table 4.4-6, included activity ratios and microcuries per gram $\mathrm{U}$ of fission products (gamma activity), $\mathrm{Pu}$ and $\mathrm{Th} .46$ The data is not sufficient for a comprehensive analysis but is included here as confirmation of Idaho RU receipts. This data appears to be incorporated in the summary presentation material prepared by C. M. West in 1985 and referenced in Section 5.1.2.

Table 4.4-6 Idaho Receipts (1964 - 1966)

\begin{tabular}{|c|c|c|c|c|c|c|}
\hline $\begin{array}{c}\text { Shipment } \\
\text { No. }\end{array}$ & $\begin{array}{c}\text { Date } \\
\text { Received }\end{array}$ & $\begin{array}{c}\text { Fission } \\
\text { Products } \\
\text { as Gamma } \\
\text { Activity } \\
\mu \text { Ci/g U }\end{array}$ & $\begin{array}{c}\text { Beta } \\
\text { Activity } \\
\text { Ratio }\end{array}$ & $\begin{array}{c}\text { Pu as Alpha } \\
\text { Activity } \\
\mu \text { Ci/g U }\end{array}$ & $\begin{array}{c}\text { Pu Alpha as } \\
\text { \% of Total } \\
\text { Alpha }\end{array}$ & $\begin{array}{c}\text { Total Alpha } \\
\text { Activity as } \\
\mathbf{d} / \mathbf{m} / \mathbf{g} \text { U }\end{array}$ \\
\hline 2 & $1-11-64$ & .60 & 1.12 & & & \\
\hline 3 & $9-14-65$ & .29 & .93 & 0.0085500 & 0.0118000 & \\
\hline 4 & $11-16-65$ & & .94 & 0.0001200 & 0.0001700 & \\
\hline 5 & $11-29-65$ & .11 & .89 & 0.0000155 & 0.0000210 & \\
\hline 6 & $12-14-65$ & .06 & .76 & 0.0000210 & 0.0000339 & \\
\hline 7 & $1-18-66$ & .30 & .7 & 0.0000067 & 0.0000100 & .000000015 \\
\hline 8 & $3-16-66$ & .25 & .5866 & 0.0000580 & 0.0000790 & .000000016 \\
\hline 9 & $3-29-66$ & .16 & .73 & 0.0000259 & 0.0000360 & .000000016 \\
\hline
\end{tabular}

No other analytical information, beyond that summarized in the 1983 report of the annual report series discussed later in Section 4.5.1, was found during this current effort. The 1983 report summarized results, shown in Table 4.5-6, included the following information on two samples of material received from ICPP:

- Average Alpha Ratio $\quad .18$

- Average Beta Ratio $\quad .74$

- Total Fission Products $\quad .01 \mu \mathrm{Ci} / \mathrm{g} \mathrm{U}$

\footnotetext{
${ }^{45}$ ICPP, Recycle Uranium Mass Balance Project, Idaho Site Report, INEEL/INT-99-01228.

${ }^{46}$ Correspondence, J.E. Vath, September 14, 2000.
} 
The RU Mass Balance Project at Idaho 77 found that analytical results reports for material shipped to the Y-12 Complex were not retained, and it is believed that those records were destroyed in accordance with established policy for record retention. The Idaho project team did locate incidental information in the form of a running log showing shipments with dates, shipping and receiving reporting identification symbol codes, and element and isotope quantities. The listing generally agrees with a listing of the type of fuels processed during each campaign throughout ICPP's processing life. In order tocompensate for the lack of

historical records, the Idaho team performed ORIGEN2 Code ${ }^{48}$ calculations for different fuels cases that were typical of fuels processed at ICPP and developed bounding estimates of constituent concentrations. Other operating data that did exist in the records, such as decontamination factors that measured the decontamination of alpha, beta, and gamma isotopes through the extraction cycles, were used to validate the calculated results and estimates. Finally, the methodology, ORIGEN calculations, and data used were validated by an independent review team which concluded that the resultant estimates were technically adequate for the current purpose.

RU shipped by Idaho to the Y-12 Complex came primarily from reprocessing aluminum clad, zirconium clad, and stainless steel clad fuels. Idaho-developed estimates of constituents in the ICPP product for the three types of fuels processed are shown in Table 4.4-7. ICPP processed aluminum clad fuel from 1953 through 1988 that constituted the majority of the material Idaho shipped to the Y-12 Complex, approximately 59\% derived from aluminum clad fuel. Approximately $20 \%$ of the material ICPP shipped to the plant was from zirconium clad fuel that ICPP processed from 1959 to 1987 . Approximately $21 \%$ of the material ICPP shipped to the plant came from stainless steel clad fuel that ICPP processed from 1966 to 1988.

The Idaho team reported that the ${ }^{236} \mathrm{U}$ concentration in the final product averaged around $10 \%$ but peaked as high as $19.1 \%$. The ${ }^{234} \mathrm{U}$ concentration averaged approximately $1 \%$ but peaked as high as $1.5 \%$.

Table 4.4-7 Constituents in Recycled Uranium from ICPP

\begin{tabular}{|l|c|c|c|}
\hline \multicolumn{1}{|c|}{ Isotope } & Aluminum Clad & Stainless Steel Clad & Zirconium Clad \\
\hline${ }^{238} \mathrm{Pu}(\% \mathrm{Pu})$ & $16 \%$ & $0 \%$ & $84 \%$ \\
\hline${ }^{239} \mathrm{Pu}(\% \mathrm{Pu})$ & $63 \%$ & $100 \%$ & $12 \%$ \\
\hline${ }^{240} \mathrm{Pu}(\% \mathrm{Pu})$ & $10 \%$ & $0 \%$ & $3 \%$ \\
\hline${ }^{241} \mathrm{Pu}(\% \mathrm{Pu})$ & $9 \%$ & $0 \%$ & $1 \%$ \\
\hline${ }^{242} \mathrm{Pu}(\% \mathrm{Pu})$ & $1 \%$ & $0 \%$ & $0 \%$ \\
\hline $\mathrm{Pu} \mathrm{Total}(\mathrm{g} / \mathrm{g} \mathrm{U}) 1953-1976$ & $4.30 \mathrm{E}-11$ & $2.125 \mathrm{E}-08$ & $1.50 \mathrm{E}-11$ \\
\hline $\mathrm{Pu} \mathrm{Total}(\mathrm{g} / \mathrm{g} \mathrm{U}) 1976-$ & $2.20 \mathrm{E}-11$ & $1.080 \mathrm{E}-08$ & $1.00 \mathrm{E}-12$ \\
\hline${ }^{237} \mathrm{~Np}(\mathrm{~g} / \mathrm{g} \mathrm{U}) 1953-1976$ & $1.187 \mathrm{E}-06$ & $3.115 \mathrm{E}-08$ & $1.633 \mathrm{E}-06$ \\
\hline${ }^{237} \mathrm{~Np}(\mathrm{~g} / \mathrm{g} \mathrm{U}) 1976-$ & $6.033 \mathrm{E}-07$ & $1.588 \mathrm{E}-08$ & $8.2990 \mathrm{E}-07$ \\
\hline${ }^{99} \mathrm{Tc}(\mathrm{g} / \mathrm{g} \mathrm{U}) 1953-$ & $1.10 \mathrm{E}-09$ & $1.8 \mathrm{E}-11$ & $1.8 \mathrm{E}-09$ \\
\hline
\end{tabular}

${ }^{47}$ ICPP, Recycle Uranium Mass Balance Project, Idaho Site Report, INEEL/INT-99-01228.

${ }^{48}$ Croff, A.G., ORIGEN2 - A Revised and Updated Version of the Oak Ridge Isotope Generation and Depletion Code, 1980.

${ }^{49}$ ICPP, Recycle Uranium Mass Balance Project, Idaho Site Report, INEEL/INT-99-01228. 


\subsection{ANALYTICAL RESULTS FOR TRU ELEMENTS AND FISSION PRODUCTS IN RECYCLED URANIUM PROCESS STREAMS AND WASTE STREAMS AT THE Y-12 COMPLEX}

\subsubsection{Process Streams}

During various periods, RU-process side streams were sampled to evaluate possible constituent concentrations, such as TRU and fission products, within the processing systems and potential associated radiological concerns. A clear differentiation was made between SRS streams, side streams, and regular streams. Side streams typically included primary and secondary extraction feed, raffinate, and residues. Others materials, such as $\mathrm{UF}_{4}$ (green salt) and caustic filtrate, were analyzed as needed. The raffinate, if below established limits for uranium, was discarded as liquid waste. If above the established limits for uranium, it was routed again through chemical recovery processing. Originally, the liquid waste was sent to the S-3 Ponds, and the solids, to the Bear Creek Burial Grounds. Since March 1984, liquid waste has been sent to holding tanks at the West End Treatment Facility (WETF) for storage and future processing.

Internal correspondence documents that samples were taken to isolate and resolve problems resulting from the accumulation of radioactive species other than uranium in SRS operations. 50 Samples were taken during September and October 1973 on sections of the Y-12 Complex Savannah River operations and analyzed for radioactive species. The analytical results for $\mathrm{Pu}, \mathrm{Np}$, Th, total alpha, ${ }^{95} \mathrm{Zr}-\mathrm{Nb}$, and ${ }^{106} \mathrm{Ru}$ in SRS metal, $\mathrm{UF}_{4}, \mathrm{UO}_{3}$, secondary feed, incinerator ash, raffinate, and evaporator material are reported and compared to the Y-12 Complex Guideline. These results are give in Table 4.5-1.

Table 4.5-1 Summary of 1973 SRS Stream Results

\begin{tabular}{|c|c|c|c|c|c|c|c|}
\hline \multirow[t]{2}{*}{ Type of Sample } & \multirow[t]{2}{*}{$\% U$} & \multicolumn{4}{|c|}{ Alpha } & \multicolumn{2}{|c|}{ Gamma } \\
\hline & & $\underset{\mathbf{U}}{\mathrm{Pu} \text { dpm/g }}$ & $\begin{array}{c}\mathrm{Np} \\
\mathrm{dpm} / \mathrm{g} U\end{array}$ & $\begin{array}{c}\text { Th } \\
\mathrm{dpm} / \mathrm{g} U\end{array}$ & $\begin{array}{c}\text { Total } \\
\text { dpm/g U }\end{array}$ & $\begin{array}{l}{ }^{\mathrm{gb}} \mathrm{Zr}-\mathrm{Nb} \\
\mathrm{dpm} / \mathrm{g} \mathrm{U}\end{array}$ & $\begin{array}{c}{ }^{106} R U \\
\mathrm{dpm} / \mathrm{g} \mathrm{U}\end{array}$ \\
\hline \multicolumn{8}{|l|}{ Savannah River } \\
\hline Metal & 100.00 & $9.0 \times 10^{3}$ & $1.2 \times 10^{5}$ & $6.15 \times 10^{4}$ & $1.9 \times 10^{5}$ & $1.3 \times 10^{5}$ & None \\
\hline $\mathrm{UF}_{4}$ & 75.70 & $5.3 \times 10^{3}$ & $6.5 \times 10^{4}$ & $1.2 \times 10^{4}$ & $8.2 \times 10^{4}$ & $2.0 \times 10^{5}$ & None \\
\hline $\mathrm{UO}_{3}$ & 82.00 & $4.5 \times 10^{3}$ & $2.2 \times 10^{5}$ & $1.7 \times 10^{4}$ & $2.4 \times 10^{5}$ & $9.5 \times 10^{4}$ & None \\
\hline Secondary Feed & 12.80 & $2.7 \times 10^{3}$ & $1.3 \times 10^{4}$ & $4.9 \times 10^{5}$ & $5.1 \times 10^{5}$ & $4.2 \times 10^{5}$ & $6.2 \times 10^{6}$ \\
\hline Incinerator Ash & 9.10 & $2.0 \times 10^{3}$ & $7.1 \times 10^{4}$ & $2.5 \times 10^{4}$ & $9.8 \times 10^{4}$ & $9.1 \times 10^{3}$ & $2.0 \times 10^{6}$ \\
\hline Raffinate & $5 p p m$ & None & $\begin{array}{l}7.4 \times 10^{1} \\
\mathrm{dpm} / \mathrm{ml}\end{array}$ & None & ---- & $1.6 \times 10^{4}$ & $\begin{array}{c}4.7 \times 10^{4} \\
\mathrm{dpm} / \mathrm{ml}\end{array}$ \\
\hline Evaporator Material & 0.25 & $5.6 \times 10^{6}$ & $2.9 \times 10^{6}$ & $1.0 \times 10^{5}$ & $8.6 \times 10^{6}$ & $8.5 \times 10^{5}$ & $2.1 \times 10^{7}$ \\
\hline
\end{tabular}

\footnotetext{
${ }^{50}$ Internal Correspondence, "Transuranics and Fission Products,” W.H. Tipton to J.R. Barkman, December 17, 1973.
} 
Also in 1973, the Y-12 Complex Chemical Services organization found an increased transuranic to uranium disintegration rate in recovery process residues. They performed an extensive review of the components contributing to the chemical recovery materials streams relating directly to the introduction and/or concentration of fission products and other radioactive constituents. A series of process-residue batches, including SRS Oralloy-related residues, were sampled and analyzed for ${ }^{237} \mathrm{~Np},{ }^{238} \mathrm{Pu},{ }^{239} \mathrm{Pu},{ }^{239-240} \mathrm{Pu},{ }^{228} \mathrm{Th},{ }^{241} \mathrm{Am},{ }^{137} \mathrm{Cs}$, and ${ }^{95} \mathrm{Zr}-\mathrm{Nb}$. Based upon the results, a closer look at the constituents in salvage materials was taken. After evaluating several possibilities for the introduction of transuranic contamination into the recovery process stream, such as material crossover, processing of returned weapons parts, cascade product, nitric acid leaching rate, and introduction at various points, they concluded that "the excessive concentration of radioactive contamination found in leached process residues is caused mainly by differences in their leaching rate with that of uranium.'

An internal correspondence report presents a review of summarized annual 1977 and 1978 results for receipts, shipments of metal and oxide, and side streams, including secondary feed, raffinates, and residues. The annual results, an average of results for the total number of samples analyzed, showed elevated alpha, beta, and gamma in the side streams, as presented in Table 4.5-2 and Table 4.5-3. The 1978 regular stream material levels were the same as previously reported $(0.004 \mu \mathrm{Ci} \mathrm{Pu}$ per gram $\mathrm{U})$. The 1978 raffinate and residue side streams showed a buildup of gamma emitters and increased alpha and beta ratios. The 1978 secondary extraction feed showed elevated gamma levels and alpha and beta ratios.

Table 4.5-2 Summary of 1977 SRS Results

\begin{tabular}{|l|c|c|c|c|}
\hline \multicolumn{1}{|c|}{ Type of Sample } & $\begin{array}{c}\text { No. of } \\
\text { Samples }\end{array}$ & $\begin{array}{c}\text { Alpha Ratio* } \\
\text { (Average) }\end{array}$ & $\begin{array}{c}\text { Beta Ratio } \\
\text { (Average) }\end{array}$ & $\begin{array}{c}\text { Total Gamma }^{\ddagger} \\
\text { (Average) }\end{array}$ \\
\hline SRS Receipts & 23 & 0.59 & 1.03 & $<0.01$ \\
\hline SRS Shipments-Metal & 11 & 0.43 & 0.87 & $<0.01$ \\
\hline SRS Shipments-Oxide & 8 & 0.37 & 0.75 & $<0.01$ \\
\hline Regular Stream-Metal & 7 & 0.06 & 0.86 & $<0.01$ \\
\hline Side Streams-Sec Feed & 3 & 12.50 & 4.40 & 5.40 \\
\hline Side Streams-Raffinates & 3 & 200.00 & 15.30 & 489.00 \\
\hline Side Streams-Residues & 3 & 7.10 & 2.85 & $<0.60$ \\
\hline
\end{tabular}

*Alpha Ratio - dpm/ $\mu \mathrm{g}$ total actinide x $700 \div 140 \mathrm{dpm} / \mu \mathrm{g}$ (nominal SA uranium) $=<1$

${ }^{\dagger}$ Beta Ratio - Activity sample $\div$ activity U sample $93 \%{ }^{235} U$, no TRU or fission products $=<1.25$

${ }^{\ddagger}$ Total Gamma $-\mu g{ }^{226}$ Ra equivalent per gram $U=<2$

\footnotetext{
${ }^{51}$ Internal Correspondence, "Contributions of Radiation in Salvage Materials," W.H. Tipton to J.R. Barkman, March 2, 1973.
} 
Table 4.5-3 Summary of 1978 SRS Results

\begin{tabular}{|l|c|c|c|c|}
\multicolumn{1}{|c|}{ Type of Sample } & $\begin{array}{c}\text { No. of } \\
\text { Samples }\end{array}$ & $\begin{array}{c}\text { Alpha Ratio* } \\
\text { (Average) }\end{array}$ & $\begin{array}{c}\text { Beta Ratio }^{\dagger} \\
\text { (Average) }\end{array}$ & $\begin{array}{c}\text { Total Gamma }^{\ddagger} \\
\text { (Average) }\end{array}$ \\
\hline SRS Receipts & 9 & 0.200 & 1.02 & $<0.01$ \\
\hline SRS Shipments-Metal & 20 & 0.430 & 0.90 & $<0.01$ \\
\hline SRS Shipments-Oxide & 11 & 0.300 & 0.93 & $<0.01$ \\
\hline Regular Stream-Metal & 6 & 0.008 & 0.86 & $<0.01$ \\
\hline Side Streams-Sec Feed & 6 & 7.200 & 3.20 & 2.70 \\
\hline Side Streams-Raffinates & 1 & 15.000 & 4.00 & 4.41 \\
\hline Side Streams-Residues & 1 & 15.300 & 2.70 & 0.60 \\
\hline Recast Metal & 44 & 0.060 & --- & -- \\
\hline
\end{tabular}

*Alpha Ratio - dpm/ $/$ g total actinide $x 700 \div 140 \mathrm{dpm} / \mu \mathrm{g}($ nominal SA uranium $) \quad=<1$

${ }^{\dagger}$ Beta Ratio - Activity sample $\div$ activity U sample $93 \%{ }^{235} U$, no TRU or fission products $=<1.25$

${ }^{\ddagger}$ Total Gamma $-\mu g{ }^{226}$ Ra equivalent per gram $U=<2$

The internal correspondence documents the continuation of efforts between Health Physics and Chemical Services Department to sample and review results from the SRS streams, side streams, and regular streams "in order to help assure that there are no unrecognized health physics problems". The correspondence report discusses the path of the impurities through the RU processing stream and concludes that "evidently the secondary extraction strips the feed material of these impurities (causing elevated alpha, beta, and gamma levels), since they do not show up at these levels in the final product (metal or oxide shipped back to SRO)." The report evaluates the concentration of the impurities found in various side streams against established limits. The correspondence shows the addition of analyses for other side streams (e.g., $\mathrm{Pu}$ and $\mathrm{Np}$ on the $\mathrm{UF}_{4}$ side stream) in meeting established material specifications.

A 1979 summary of results for samples taken on SRS receipts, products, intermediates and salvage, and melts from RF returns and regular stream material are presented in Table 4.5-4 below. ${ }_{3}$ The correspondence provided several observations on the data:

- All samples of SRS receipts and shipments of SRS product were well within the established specifications for alpha emitters. This was the case for the first time since establishment of the program. There had been a continued improvement in the levels of the alpha contaminants monitored; specifically, plutonium levels were down an order of magnitude and neptunium levels were down by a factor of three, but ${ }^{232} \mathrm{U}$ and its daughter ${ }^{228}$ Th remained constant.

- The results on products being returned to SRS were similar, except that ${ }^{228}$ Th levels had gone up by a factor of 1.5. This rise was due to a greater length of time between the steps that purify the $\mathrm{U}$ and $\mathrm{Th}$ and to the time the analysis is performed.

\footnotetext{
52 Internal Correspondence, "SRO Results," C.M. West to J.R. Barkman, April 26, 1979.

${ }^{53}$ Internal Correspondence, "Savannah River Operations (SRO) and Rocky Flats Results," C.M. West to J.R. Barkman, June 2, 1980.
} 
- Although the alpha, beta, and gamma ratios for raffinate continued to be above "acceptance" specifications, they were lower than those experienced in 1977, and because they relate to the concentrations of uranium in solutions having extremely low concentrations of uranium, which are to be discarded, they had no health physics significance.

Table 4.5-4 1979 Summary of SRS and RF Results

\begin{tabular}{|l|c|c|c|c|}
\hline \multicolumn{1}{|c|}{ Type of Sample } & No. of Samples & $\begin{array}{c}\text { Alpha Ratio } \\
\text { (Average) }\end{array}$ & $\begin{array}{c}\text { Beta Ratio } \\
\text { (Average) }\end{array}$ & $\begin{array}{c}\text { Total Gamma }^{\ddagger} \\
\text { (Average) }\end{array}$ \\
\hline SRS Receipts & 16 & 0.27 & 1.04 & $<0.01$ \\
\hline SRS Shipments-Metal & 17 & 0.31 & 0.89 & $<0.01$ \\
\hline SRS Shipments-Oxide & 1 & 0.13 & 0.67 & $<0.01$ \\
\hline Regular Stream-Metal & 1 & 0.09 & 0.76 & $<0.01$ \\
\hline Side Streams-Sec Feed & 4 & 3.67 & 2.35 & 1.31 \\
\hline Side Streams-Raffinates & 3 & 34.14 & 3.71 & 6.17 \\
\hline Recast Metal & & & & - \\
$\quad$ Rocky Flats Returns & 55 & 0.03 & --- & - \\
\hline Others & 13 & 0.02 & --- & - \\
\hline
\end{tabular}

*Alpha Ratio - dpm/ $\mu \mathrm{g}$ total actinide $x 700 \div 140 \mathrm{dpm} / \mu \mathrm{g}$ (nominal SA uranium) $=<1$

${ }^{\dagger}$ Beta Ratio - Activity sample $\div$ activity $U$ sample $93 \%{ }^{235} U$, no TRU or fission products $=<1.25$

${ }^{\ddagger}$ Total Gamma $-\mu g{ }^{226}$ Ra equivalent per gram $U=<2$

Table 4.5-5 documents a 1981 summary of certain SRS, RF, and regular stream analytical results. Internal correspondence in May 1982 was one of a continual annua _series that evaluated fission product and/or transuranic contamination in these streams. ${ }_{54}$ The evaluation concluded that although there was more plutonium in SRS and RF returns than in recent years, the levels remained below the Y-12 Complex specifications and there were no significant health physics concerns. Specific comments from the report include:

- Sampling of metal prior to making SRS shipments showed a higher alpha ratio level than did the returns. Although the greatest contributor to the alpha ratio on this metal was usually ${ }^{228} \mathrm{Th}, \mathrm{Pu}$ was a significant contributor to the levels of the shipments sampled in December 1981.

- Although the alpha ratios on the side streams were greater than the specification, they were less than those obtained in prior years.

- Both SRS and Y-12 Complex analyses indicated that plutonium levels on receipts had returned to about nominal levels in 1982 and were down to about the same levels as in early 1981.

\footnotetext{
${ }^{54}$ Internal Correspondence, "Analyses of Savannah River Operations (SRO) and Rocky Flats Returns," C.M. West to J.R. Barkman, May 3, 1982.
} 
Table 4.5-5 Summary of 1981 SRS Results

\begin{tabular}{|c|c|c|c|c|}
\hline Type of Sample & No. of Samples & $\begin{array}{l}\text { Alpha Ratio* } \\
\text { (Average) }\end{array}$ & $\begin{array}{c}\text { Beta Ratio }^{\dagger} \\
\text { (Average) }\end{array}$ & $\begin{array}{c}\text { Total Gamma } \\
\text { (Average) }\end{array}$ \\
\hline SRS Receipts & 27 & 0.25 & 0.99 & $<0.01$ \\
\hline SRS Shipments-Metal & 31 & 0.32 & 0.87 & $<0.01$ \\
\hline$S R S-U_{4}$ & 4 & 0.32 & 0.80 & $<0.01$ \\
\hline Regular Stream-Metal & 2 & 0.08 & 0.85 & $<0.01$ \\
\hline Side Streams-Sec Feed & 3 & 2.39 & 1.49 & 0.12 \\
\hline Side Streams-Raffinates & 3 & 12.09 & 4.63 & 2.82 \\
\hline Side Streams-Residues & 3 & 1.52 & 0.84 & 0.54 \\
\hline \multicolumn{5}{|l|}{ Recast Metal } \\
\hline Rocky Flats Returns & 63 & 0.06 & & \\
\hline Regular & 123 & 0.02 & & \\
\hline Briquette Pours & 116 & 0.02 & & \\
\hline
\end{tabular}

Tables 4.5-6 and 4.5-7 document a summary of 1983 and 1984 results for ${ }^{228} \mathrm{Th}$, transuranics, and fission prodycts on reactor returns from Savannah River and Idaho and teardown parts for Rocky Flats. ${ }^{55}$ Results from regular stream uranium were included for comparison. The report stated the following:

- The 1984 average for the alpha ratio for SRS receipts was the highest it had been since 1977. Elevated ${ }^{228}$ Th concentrations are chiefly responsible for the level of the results in 1983.

- $\quad$ The ${ }^{237}$ Neptunium level in 1984 was about four times its level in 1983 and 1982. Health Physics talked to Savannah River about this increase and the ${ }^{237} \mathrm{~Np}$ concentrations subsequently returned to levels more typical of earlier results after adjustments were made to the process.

- Very few side stream results were taken in 1983 and none in 1984. It was recommended that side stream sampling be reinstated and 10 to 20 samples be gathered annually.

- Although the side stream alpha ratio continued to be above the specifications for acceptance of uranium, it was judged that this fact had little, if any, health physics significance since the sampled streams were extremely dilute in uranium.

\footnotetext{
${ }^{55}$ Internal Correspondence, "Savannah River Operations (SRO) and Rocky Flats Results," C.M. West to D.W. Smith, July 5,1985.
} 
Table 4.5-6 1983 Summary of SRS, ICPP, and RF Results

\begin{tabular}{|c|c|c|c|c|}
\hline Type of Sample & No. of Samples & $\begin{array}{l}\text { Alpha Ratio* } \\
\text { (Average) }\end{array}$ & $\begin{array}{c}\text { Beta Ratio }^{\dagger} \\
\text { (Average) }\end{array}$ & $\begin{array}{c}\text { Total Gamma } \\
\text { (Average) }\end{array}$ \\
\hline SRS Receipts & 54 & 0.30 & 0.82 & 0.100 \\
\hline SRS Shipments-Metal & 20 & 0.36 & 0.85 & 0.001 \\
\hline Idaho Receipts & 2 & 0.18 & 0.74 & 0.010 \\
\hline Idaho Shipments & 5 & 0.10 & 0.60 & 0.001 \\
\hline \multicolumn{5}{|l|}{ SRS Side Streams } \\
\hline Caustic Filtrate & 1 & 93.70 & --- & --- \\
\hline $\mathrm{UF}_{4}$ & 1 & 0.05 & 0.85 & 0.000 \\
\hline Raffinates & 1 & 21.60 & 4.2 & 5.490 \\
\hline Sec Extract Feed & 1 & 8.00 & 2.2 & 1.680 \\
\hline \multicolumn{5}{|l|}{ Recast Metal ${ }^{\S}$} \\
\hline Rocky Flats Returns & 78 & 0.05 & & \\
\hline Regular & 461 & 0.02 & & \\
\hline Briquette Pours & 98 & 0.02 & & \\
\hline
\end{tabular}

Table 4.5-7 1984 Summary of SRS and RF Results

\begin{tabular}{|l|c|c|c|c|}
\hline \multicolumn{1}{|c|}{ Type of Sample } & No. of Samples & $\begin{array}{c}\text { Alpha Ratio* } \\
\text { (Average) }\end{array}$ & $\begin{array}{c}\text { Beta Ratio }^{\dagger} \\
\text { (Average) }\end{array}$ & $\begin{array}{c}\text { Total Gamma }^{\ddagger} \\
\text { (Average) }\end{array}$ \\
\hline SRS Receipts & 32 & 0.38 & 0.76 & 0.113 \\
\hline SRS Shipments-Metal & 31 & 0.26 & 0.71 & 0.007 \\
\hline SRS Side Streams & 0 & & \\
\hline Recast Metal & & & \\
\hline Rocky Flats Returns & 27 & 0.04 & \\
\hline Regular & 183 & 0.03 & \\
\hline Briquette Pours & 75 & 0.02 & \\
\hline
\end{tabular}

*Alpha Ratio $-d p m / \mu g$ total actinide $x 700 \div 140 \mathrm{dpm} / \mu \mathrm{g}($ nominal SA uranium $)=<1$

${ }^{\dagger}$ Beta Ratio - Activity sample $\div$ activity U sample $93 \%{ }^{235} U$, no TRU or fission products $=<1.25$

${ }^{\ddagger}$ Total Fission Products $\quad=<0.2 \mu \mathrm{Ci}$

${ }^{\S} \mathrm{Pu}$ analyses only

Internal correspondence from 1985 documents that Operations and Health Physics staff routinely monitored SRS-processing side streams and waste streams including secondary feed, raffinates, and residues in liquid and solid phases for both TRU and fission products. "Sampling of the recovery-process side streams was performed during RU processing at Y-12 Plant and results have shown that there is some concentration of contaminants in both liquid and solid-waste streams." Historically, the liquid waste was then sent to the S-3 
Ponds, and the solids, to the Bear Creek Burial Grounds. In more recentyears, since March 1984, liquid waste has been sent to holding tanks for future processing.

Analytical results for some of the secondary extraction raffinate samples taken during the period 1978 to 1988 are shown in Table 4.5-8. Scatterplots of the Pu and Np results for this data set are shown in Figures 4.5-1 and 4.5-2.

Table 4.5-8 Analytical Results for Secondary Raffinate Samples

\begin{tabular}{|c|c|c|c|c|c|}
\hline $\begin{array}{c}\text { Secondary Extraction } \\
\text { Raffinate }\end{array}$ & Valid N & Mean & Minimum & Maximum & Std. Dev. \\
\hline$\%{ }^{235} \mathrm{U}$ & 0 & & & & \\
\hline$\%{ }^{236} U$ & 5 & 28.6500000 & 22.250 & 34.370 & 5.5699955 \\
\hline${ }^{238,}{ }^{240} \mathrm{Pu} \mu \mathrm{Ci} / \mathrm{g} \mathrm{U}$ & 11 & 0.0317273 & 0.003 & 0.175 & 0.0496288 \\
\hline${ }^{237} \mathrm{~Np} \mu \mathrm{Ci} / \mathrm{g} U$ & 11 & 0.3288182 & 0.039 & 0.922 & 0.2830296 \\
\hline${ }^{228} \mathrm{Th} \mu \mathrm{Ci} / \mathrm{g} \mathrm{U}$ & 11 & 1.2766364 & 0.201 & 7.680 & 2.1689982 \\
\hline Total Actinides $\mu \mathrm{Ci} / \mathrm{g} U$ & 11 & 1.5793636 & 0.154 & 8.325 & 2.3009750 \\
\hline${ }^{232} \mathrm{U} \mu \mathrm{Ci} / \mathrm{g} U$ & 11 & 1.5463636 & 0.615 & 3.090 & 0.7779545 \\
\hline${ }^{232} \mathrm{U} \mu \mathrm{Ci} / \mathrm{g} U$ & 4 & 0.5352500 & 0.432 & 0.634 & 0.0895074 \\
\hline${ }^{232} \mathrm{U}$ ppm & 8 & 0.0307500 & 0.002 & 0.070 & 0.0193298 \\
\hline 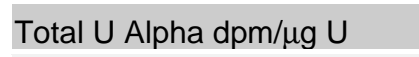 & 11 & 216.1590900 & 140.000 & 245.000 & 27.5592830 \\
\hline Alpha Ratio & 10 & 18.8986000 & 3.600 & 92.430 & 26.4823430 \\
\hline
\end{tabular}

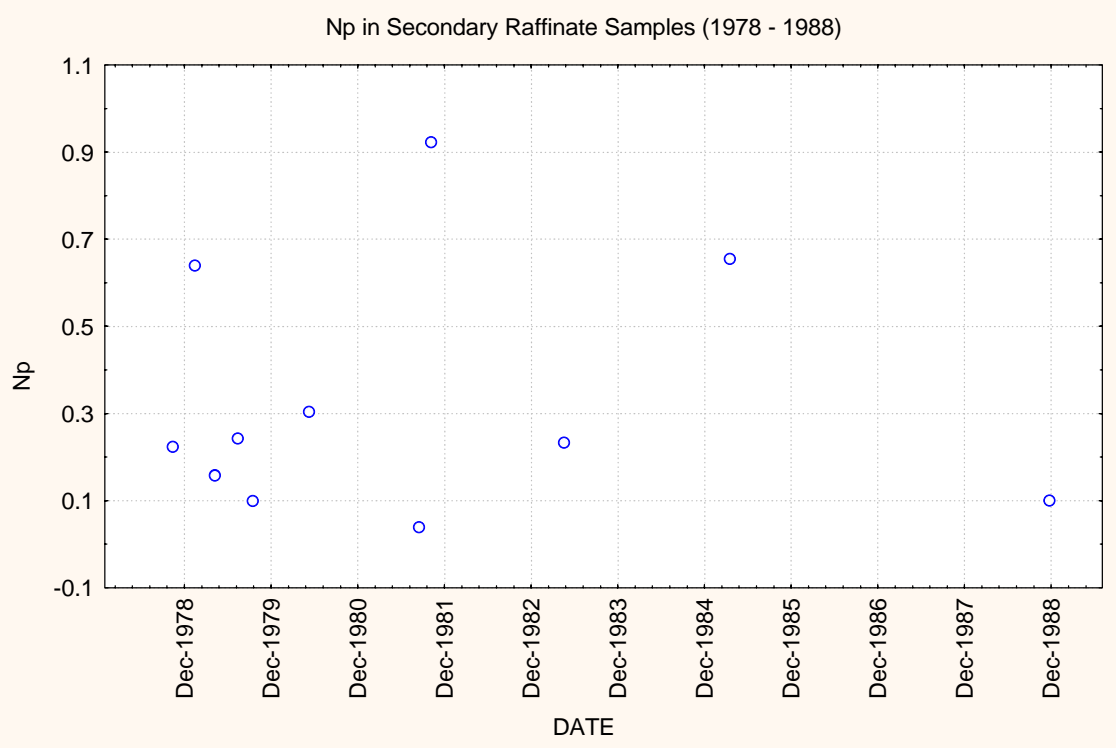

Fig. 4.5-1 Pu in Secondary Raffinate (1978 - 1988).

\footnotetext{
${ }^{56}$ Internal Correspondence, "Radioactive Contaminants in Uranium Reactor Returns Processed at Y-12," J.B. Hunt to E. Owings, September 11, 1985.
} 


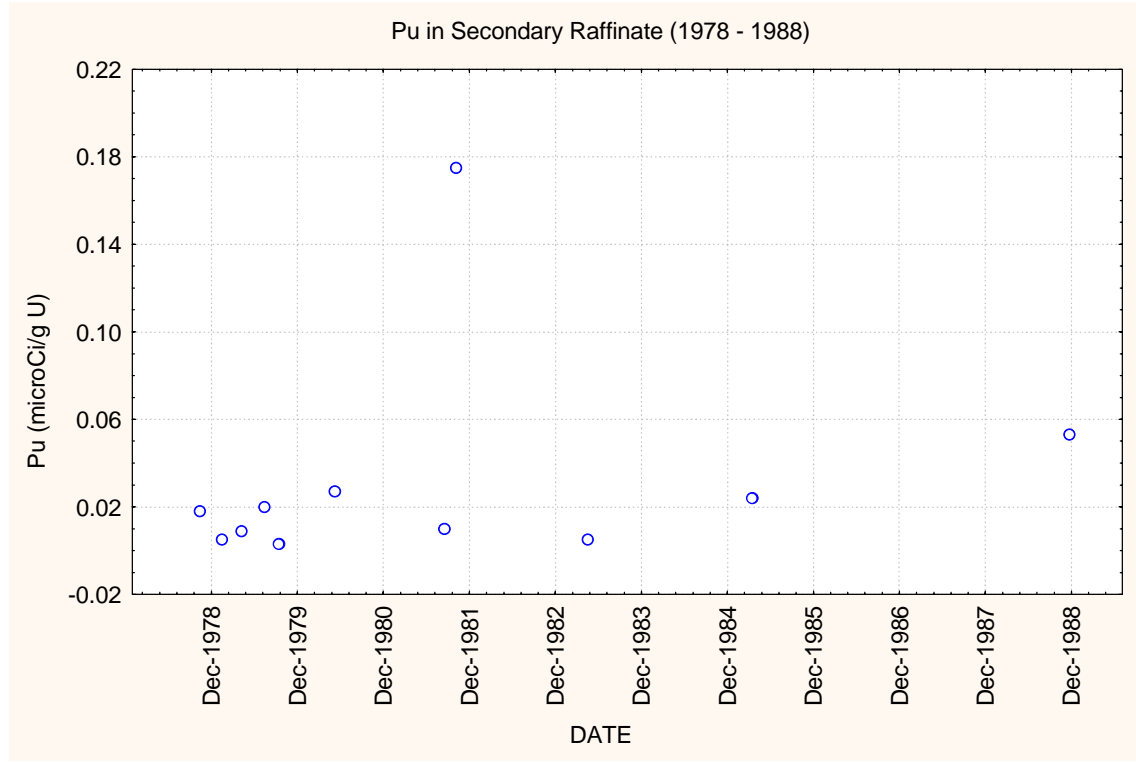

Fig. 4.5-2 Np in Secondary Raffinate (1978 - 1988).

\subsubsection{Waste Streams}

\subsubsection{S-3 Ponds}

The S-3 Ponds were designed for collecting nitric acid and other nitrate wastes generated by processes within the Y-12 Complex. Four unlined ponds, each about 200 square feet, were constructed south of Bear Creek Road and west of Old Bear Creek Road near Building 9420, the consolidated construction shops. Initially, nitrated waste was transported in containers and dumped directly into the ponds. Later, a dedicated pipeline from the main processing buildings was installed, and waste was pumped directly to the ponds.

The average annual plant volume collected was about 2.7 million gallons per year of nitrated waste. That eventually resulted in a $\mathrm{pH}$ before treatment of less than 2 . Rainfall was estimated at 4 to 6 million gallons per year, and evaporation was estimated at 3 million gallons per year. The ponds never overflowed nor went dry. The excess liquid percolated through the bottom of the ponds into the groundwater. The ponds were used for about 32 years to collect nitric acid and other nitrate waste from plant operations. During the early 1980s, a biodenitrification process was constructed to reduce the soluble nitrogen concentration before discharging the liquid for further treatment and release under a NPDES permit.

The ponds were closed by adding rock and gravel, leveling, and then capping the entire area with RCRA-approved asphalt cover. The site is currently being used as a parking lot. Subsequently, the groundwater was found to be contaminated with uranium, nitrates, cadmium, volatile organic compounds (VOCs), and other soluble elements and compounds. Three pathways of contaminated groundwater flow originating from the S-3 Ponds were identified. DOE entered an agreement with regulatory agencies to remediate the groundwater through three in-situ treatment processes, each tailored for a specific pathway. 
Before capping work began on the ponds, sludge samples were taken from each pond to ascertain the airborne (internal) exposure potential, if any, for workers placing the cap materials. Those samples were analyzed, and the initial determination resulted in a finding that no special precautions were needed for this work, other than the normal requirements for handling depleted uranium (equivalent to a mixture of $1.2 \mathrm{wt} \% \mathrm{DU}$ ). The second evaluation included the effects from thorium and strontium and concluded that the material should be treated as a mixture of $45 \mathrm{wt} \%{ }^{238} \mathrm{U}$. The primary reason for the dramatic increase in the exposure potential was the inclusion of ${ }^{230} \mathrm{Th}$ and ${ }^{228} \mathrm{Th}$. These two isotopes contributed about $90 \%$ of the internal exposure potential.

The samples were collected in November 1984 while the ponds contained a relatively large amount of liquid. Samples were taken by dragging a capped three-inch diameter pipe through the sludge at three or four different locations in each pond. ${ }^{57}$ The sample results from each pond are shown in Tables 4.5-9 through 4.5-12.

Table 4.5-9 S-3 Pond Sludges Radiological Analyses Data

\begin{tabular}{|c|c|c|c|c|c|}
\hline \multicolumn{6}{|c|}{$\begin{array}{l}\text { S-3 Pond Sludges - Total Radiological Analyses Data } \\
\text { (picoCi/g wet weight) }\end{array}$} \\
\hline & SW & NW & NE & SE & Average \\
\hline Alpha Activity & 895 & 420 & 960 & 870 & 790 \\
\hline Beta Activity & 1,150 & 680 & 1,300 & 2,100 & 1,310 \\
\hline \multicolumn{6}{|l|}{ Non $\cup \gamma$ Activity } \\
\hline${ }^{137} \mathrm{Cs}$ & $<5$ & $<5$ & $<5$ & $<5$ & $<5$ \\
\hline${ }^{106} \mathrm{Ru}$ & 19 & $<5$ & 43 & 23 & 23 \\
\hline${ }^{237} \mathrm{~Np}$ & 7.1 & 5.7 & 12 & 8 & 8.2 \\
\hline${ }^{238} \mathrm{Pu}$ & 27 & 15 & 3.1 & 5.5 & 12.7 \\
\hline${ }^{239,}{ }^{240} \mathrm{Pu}$ & 2.6 & $<1.6$ & 2.3 & $<1.6$ & 2 \\
\hline${ }^{90} \mathrm{Sr}$ & 14 & 4.2 & 5 & 10 & 8.3 \\
\hline${ }^{99} \mathrm{Tc}$ & 930 & 1,200 & 790 & $12,000^{*}$ & 3,730 \\
\hline${ }^{228} \mathrm{Th}$ & 280 & 160 & 270 & 210 & 230 \\
\hline${ }^{230} \mathrm{Th}$ & 520 & 210 & 370 & 570 & 418 \\
\hline${ }^{232} \mathrm{Th}$ & 47 & 100 & 15 & 32 & 49 \\
\hline${ }^{95} \mathrm{Zr}$ & ND & ND & ND & ND & ND \\
\hline
\end{tabular}

* As discussed later in Chapter 5, Tc residues from ORGDP disposed of directly into the S-3 Ponds account for the large concentration of Tc in this pond.

\footnotetext{
${ }^{57}$ Union Carbide Corporation, The Chemical and Radiological Characterization of the S-3 Ponds, Y-12 Plant, Y/MA-6400, July 14,1983.

${ }^{58}$ LMES Internal Correspondence, "Exposure Potential from S-3 Pond Dried Sludge," C.M. West to H. D. Whitehead, April 16, 1985.
} 
Table 4.5-10 S-3 Pond Sludges Uranium Analyses

\begin{tabular}{|l|c|c|c|c|c|c|}
\multicolumn{7}{|c|}{ S-3 Pond Sludges - Total Metals and Analyses Data } \\
( 1 g/g wet weight)
\end{tabular}

Table 4.5-11 S-3 Pond Sludges - EP Toxicity Extraction Data

\begin{tabular}{|l|c|c|c|c|c|}
\hline \multicolumn{7}{|c|}{$\begin{array}{l}\text { S-3 Pond Sludges - EP Toxicity Extraction Data } \\
\text { (picoCi/liter extract) }\end{array}$} \\
\hline & SW & NW & NE & SE & Average \\
\hline Alpha Activity & 3,100 & 3,200 & 5,700 & 3,500 & 3,875 \\
\hline Beta Activity & 2,800 & 2,800 & 6,500 & 8,700 & 8,700 \\
\hline Non U $\gamma$ Activity & ND & ND & ND & ND & ND \\
\hline${ }^{237} \mathrm{~Np}$ & 14 & 29 & 130 & $<6$ & 44 \\
\hline${ }^{238} \mathrm{Pu}$ & 3.1 & $<0.2$ & 0.33 & 0.21 & 0.96 \\
\hline${ }^{239,240} \mathrm{Pu}$ & $<0.2$ & $<0.2$ & $<0.2$ & $<0.2$ & $<0.2$ \\
\hline${ }^{99} \mathrm{Tc}$ & $<1,200$ & 2,500 & 5,600 & 8,900 & 4,500 \\
\hline
\end{tabular}

Table 4.5-12 Groundwater Toxicity Extraction Data

\begin{tabular}{|l|c|c|c|c|c|}
\hline \multicolumn{7}{|c|}{$\begin{array}{l}\text { S-3 Pond Sludges - EP Toxicity Extraction Data } \\
\text { (picoCi/liter extract) }\end{array}$} \\
\hline & SW & NW & NE & SE & Average \\
\hline Alpha Activity & 3,100 & 3,200 & 5,700 & 3,500 & 3,875 \\
\hline Beta Activity & 2,800 & 2,800 & 6,500 & 8,700 & 8,700 \\
\hline Non U $\gamma$ Activity & ND & ND & ND & ND & ND \\
\hline${ }^{237} \mathrm{~Np}$ & 14 & 29 & 130 & $<6$ & 44 \\
\hline${ }^{238} \mathrm{Pu}$ & 3.1 & $<0.2$ & 0.33 & 0.21 & 0.96 \\
\hline${ }^{239}, 240 \mathrm{Pu}$ & $<0.2$ & $<0.2$ & $<0.2$ & $<0.2$ & $<0.2$ \\
\hline${ }^{99} \mathrm{Tc}$ & $<1,200$ & 2,500 & 5,600 & 8,900 & 4,500 \\
\hline
\end{tabular}

Assay measurements in Figure 4.5-10 showed the uranium in the sludge to be depleted $\left(0.29-0.39 \%{ }^{235} \mathrm{U}\right)$ and of concentration range $769-1040 \mu \mathrm{g} \mathrm{U} / \mathrm{g}$ wet weight. Health Physics determined that the exposure potential for dried sludge with $45 \%{ }^{238} \mathrm{U}$ was expected to be small as long as it was left in place. However, they provided additional recommendations for personnel working around the S-3 Ponds as they were closed; i.e., as the solution is removed and the sludge dries: "If there are operations which involve handling this sludge in a dry form 
under conditions where it dusts, respirators should be worn until Health Physics can make an evaluation of the actual conditions."

\subsubsection{West End Treatment Facility (WETF), Building 9616-7}

Since 1984 the West End Treatment Facility (WETF) has treated industrial wastewaters that were generated throughout the Y-12 Complex, including recycled uranium liquid waste streams. Sludge that is generated as a result of WETF operations is stored in Tanks F-7, F-8, F-9, and F-13. The sludge has been sampled on several occasions to characterize the radiological constituents.

In 1997, the Y-12 Complex Health Physics organization initiated a sampling program that included the entire flow of the process. ${ }^{60}$ The potential for transuranic contamination to be introduced into the various waste streams/processes in existence today was evaluated, including the WETF.

The sludge was analyzed for all radionuclides in this assessment. The sampling events revealed elevated levels of ${ }^{228} \mathrm{Th},{ }^{230} \mathrm{Th}$, and ${ }^{237} \mathrm{~Np}$. Activity ratios of uranium isotopes to non-uranium radionuclides in the sludge are 20:1 on average. This takes into account proper categorization of the contribution of ${ }^{228} \mathrm{Th}$ and ${ }^{230} \mathrm{Th}$. Based upon these ratios, the contamination limit and exposure potential have been re-evaluated, and measures have been taken accordingly; e.g., the removable contamination limit may be established at 420 $\mathrm{dpm} / 100 \mathrm{~cm}^{2}$ based on this set of data alone. It should be noted that this is an on-going process; the tanks are sampled periodically, as well as incoming tankers.

\subsubsection{New Hope Pond Closure}

East Fork Poplar Creek begins in the Y-12 Complex and primarily serves as a drainage ditch for surface runoff waters from the Y-12 Complex. A man-made pond, called "New Hope Pond," was constructed to serve as a sediment-settling basin and was located at the exit from the plant. The outlet stream from the pond flows through the city of Oak Ridge and into the Clinch River.

In 1973, New Hope Pond was dredged, and the resultant sludge was transferred to a basin located on Chestnut Ridge. In 1983, tests were performed to determine if the sediment that had accumulated in the pond was a hazardous material. The sediment analysis and leach test completed one of the memorandums of agreement made by DOE with the EPA and the state of Tennessee. ${ }^{61}$ Core samples were taken and analyzed by the Y-12 Complex Laboratory for various contaminants as received and after leaching per EPA Leach Test Requirements (e.g., Extraction Procedure Toxicity Test) Data from the leach test showed that the sediment was not hazardous per RCRA definition. ${ }^{62}$ Results were obtained for ${ }^{235} \mathrm{U}$ isotopic assay and concentrations of $\mathrm{U}, \mathrm{Pu}, \mathrm{Np}, \mathrm{Th}$, and Tc in the sediment, as shown in Table 4.5-13.

\footnotetext{
${ }^{59}$ Internal Correspondence, "Exposure Potential From S-3 Pond Dried Sludge," C.M. West to H.D. Whitehead, April 16, 1985, and June 3, 1985.

${ }^{60}$ Lockheed Martin Energy Systems, Inc., Transuranic Hazard Assessment at the Y-12 Plant, July 29, 1997.

${ }^{61}$ Sediment and Leach Test of Sediments Taken from New Hope Pond, Y/DZ-80, M.B Saunders, Development Division, June 15,1983.

${ }^{62}$ Leachability of Samples from New Hope Pond Disposal Basin, Y/DZ-81, M.B. Saunders, Nuclear Materials Processing and Waste Management Technology Department, Development Division, Y-12 Plant, July 26,1983.
} 
Table 4.5-13 New Hope Pond Sediment Analysis

\begin{tabular}{|c|c|c|c|c|c|c|c|}
\hline \multicolumn{8}{|c|}{ SAMPLE LOCATIONS } \\
\hline Contaminants & 1 & 2 & 3 & 4 & 5 & 6 & 7 \\
\hline$U(\mu g / g)$ & 370.00 & 535.00 & 550.00 & 700.00 & 560.00 & 970.00 & 755.00 \\
\hline${ }^{235} \mathrm{U}(\%)$ & 0.63 & 0.84 & 0.79 & 0.88 & 1.20 & 0.59 & 0.91 \\
\hline Th $(\mu g / g)$ & 130.00 & 100.00 & 160.00 & 130.00 & 72.00 & 130.00 & 94.00 \\
\hline $\mathrm{Tc}(\mathrm{nCi} / \mathrm{g})$ & $<0.22000$ & $<0.22000$ & $<0.22000$ & $<0.22000$ & $<0.22000$ & $<0.22000$ & $<0.22000$ \\
\hline $\mathrm{Np}(\mathrm{nCi} / \mathrm{g})$ & 0.05000 & 0.03600 & 0.06000 & $<0.01000$ & 0.07400 & 0.01300 & $<0.01000$ \\
\hline${ }^{238} \mathrm{Pu}(\mathrm{nCi} / \mathrm{g})$ & 0.00003 & 0.00007 & 0.00007 & 0.00010 & 0.00009 & 0.00007 & 0.00009 \\
\hline${ }^{239} \mathrm{Pu}(\mathrm{nCi} / \mathrm{g})$ & 0.00008 & 0.00016 & 0.00016 & 0.00023 & 0.00021 & 0.00016 & 0.00022 \\
\hline${ }^{240} \mathrm{Pu}(\mathrm{nCi} / \mathrm{g})$ & 0.00004 & 0.00006 & 0.00006 & 0.00009 & 0.00008 & 0.00006 & 0.00008 \\
\hline Alpha $(\mathrm{nCi} / \mathrm{g})$ & 0.62500 & 0.68500 & 0.99000 & 0.99000 & 0.84000 & 1.12000 & 1.00000 \\
\hline Beta $(n C i / g)$ & 0.45000 & 0.93500 & 1.12500 & 0.80000 & 0.71500 & .86500 & .89000 \\
\hline
\end{tabular}

- Nanograms of ${ }^{239} \mathrm{Pu}$ were obtained from ${ }^{242} \mathrm{Pu}$ spike isotope dilution mass spectrometry.

- Extraction and analysis of ${ }^{239 / 240} \mathrm{Pu}$ ratio resulted in an average of 10:1 (avg. of 5 of the 7 samples).

- Ratio of $0.00031 \mathrm{nCi} i^{238 / 239,240} \mathrm{Pu}$ was used to calculate ${ }^{238} \mathrm{Pu}$.

- Specific activity of ${ }^{239} \mathrm{Pu}=1.38 \times 10^{5} \mathrm{dpm} / \mu \mathrm{g}$, and $240 \mathrm{Pu}=5.08 \times 10^{5} \mathrm{dpm} / \mu \mathrm{g}$.

\subsection{ANALYTICAL RESULTS FOR TRU ELEMENTS AND FISSION PRODUCTS IN FACILITIES AND EQUIPMENT IN WHICH RU WAS PROCESSED AT THE Y-12 COMPLEX}

In early 1997, the Y-12 Complex initiated a sampling program to validate if current radiological controls/monitoring criteria were appropriate for controlling personnel exposures and contamination associated with uranium recycle material processing. $\frac{63}{3}$ To be conservative, this was expanded for the entire flow of the process. Additionally, the potential for transuranic constituents to be introduced into the various waste streams/processes in existence today was evaluated. In general, if the ratio of uranium to transuranics is high, the radiological controls based upon uranium are adequate to control the additional activity concerns presented by the transuranics. There is a point however, where the hazard presented by the transuranic activity becomes the dominant activity. For the case of contamination control, the removable contamination limit is the limiting factor to consider. The ratio of the uranium to transuranic removable contamination limit is 50:1 (1,000:20). This ratio is used as the guideline for determining when transuranic contamination controls must be instituted. Any area that is characterized by a U:TRU activity ratio greater than or equal to 50:1 will not exceed the TRU limits if the total activity does not exceed the uranium limits. Therefore, the uranium limits will be used in these areas. Conversely, transuranic limits are used in any area characterized by a U:TRU activity ratio less than 50:1.

The RADCON organization conducted surveys for potential transuranic constituents in a broad cross section of accessible areas where contamination was present, in those locations that were associated with the recycle uranium process flow and equipment. Locations

\footnotetext{
${ }^{63}$ Lockheed Martin Energy Systems, Inc., Transuranic Hazard Assessment at the Y-12 Plant; July 29, 1997.
} 
selected were Bldgs. 9212, 9206, 9812, 9818, 9616-7, as well as component fabrication areas in Bldgs. 9202, 9205, 9215, and 9212. Collectively, 79 locations were sampled and 16 duplicates of these locations were selected for a total of 95 samples that were initially analyzed. Samples were analyzed for U isotopes, ${ }^{237} \mathrm{~Np},{ }^{238} \mathrm{Pu}$ and ${ }^{239} \mathrm{Pu},{ }^{241} \mathrm{Am}$, and isotopic Th. Based upon a review of the data from all of the workplace samples that were taken, no results were below the established criteria limits (uranium to transuranic activity ratio of 50:1), and it was concluded that uranium is the dominant hazard. Additionally, it was determined that the current uranium bioassay program is adequate to ensure that there are no significant transuranic exposures being underestimated. One area of concern was the West End Treatment Facility (WETF) holding-tanks and the activities associated with the sludge removal. Based upon this study, several improvements were identified for incorporation into the Y-12 Complex RADCON program. First, this type of assessment will become an ongoing program, specifically in reference to future decontamination and decommissioning activities. Secondly, the TRU bioassay-sampling trigger level will be formalized with a technical paper, and third, communications will be improved between RADCON and other organizations.

\subsection{ANALYTICAL RESULTS FOR TRU ELEMENTS AND FISSION PRODUCTS IN MATERIAL RELEASES ASSOCIATED WITH RU AT THE Y-12 COMPLEX}

The monitoring of material releases at the Y-12 Complex historically focused on uranium, and the associated environmental monitoring generally followed the uranium release pathways for air, water, and soil. It is important to remember from an analytical measurement standpoint that RU represented a small fraction of the total uranium processed at the Y-12 Complex and that the TRU and fission products were trace constituents in the RU stream. Regarding the waste stream disposition flow and any associated material releases, TRU and fission product constituents from RU material were diluted by other uranium process streams.

Historically, potential releases to the off-site environment from recycle uranium processing, storage, and transportation came from contaminated scrap, sewer water, and ventilation or process exhaust stack releases. Uranium-contaminated materials included primarily airborne particulates, condensates, scrubber solutions, raffinates, and miscellaneous residues. Mechanisms for release of uranium to the air included releases from various operations to building vents, solid/combustible incinerator filtered exhaust systems, and recovery operation releases through the scrubber systems and filtered exhaust systems. Mechanisms for release of uranium to surface waters included conyersion and recovery operations to drains and surface runoff from contaminated areas. 64

As discussed earlier in Section 4.5, the liquid waste from RU processing was historically sent to the S-3 Ponds and the solids to the Y-12 Complex burial grounds. Since March 1984, liquid waste has been sent to holding tanks at the West End Treatment Facility (WETF) for processing. Results of routine monitoring of the RU material processing side streams and waste streams, including secondary feed, raffinates, and residues in liquid and solid phases for both TRU and fission products ${ }^{65}$ showed there was a concentration of the constituents in

\footnotetext{
${ }^{64}$ Buddenbaum, Uranium Releases from the Oak Ridge Reservation, 1999.

${ }^{65}$ Internal Correspondence, "Radioactive Contaminants in Uranium Reactor Returns Processed at Y-12," J.B. Hunt to E. Owings, September 11, 1985.
} 
both liquid and solid-waste streams. A portion of the TRU and fission product constituents would then have flowed with the uranium waste streams to these on-site disposal areas.

The Y-12 Complex is currently preparing a site-wide environmental impact statement to encompass the proposed new HEU Storage Facility and Special Materials Missions, as well as ongoing missions. A Preliminary Draft reviewed the historical data and states, "groundwater in the Bear Creek Valley west of the Y-12 Plant has been contaminated by hazardous chemicals and radionuclides (mostly uranium) from past weapons production waste disposal activities." 66 The contaminant sources include past waste disposal facilities, including the S-3 Ponds, the Oil Landfarm, the Boneyard/ Burnyard Site, and the Bear Creek Burial Grounds, all closed since 1988. Each site was used for the disposal of waste chemicals, including acids, solvents, oils, radioactive material (e.g., uranium), and wastewater containing dissolved metals and radionuclides. As a result, the groundwater beneath and downhill of the disposal facilities is contaminated with nitrate, solvents, radionuclides (e.g., uranium isotopes and Tc), and metals (e.g., uranium, cadmium, and strontium). 67

Several multi-year efforts have been conducted to analyze environmental monitoring data and associated environmental impacts. The issued reports provide a comprehensive evaluation of release data for uranium and some radionuclides over the period of years during which RU was processed at the Y-12 Complex and are used in this report. The DOE-ORO report, Historical Radionuclide Releases from Current DOE Oak Ridge Operations Office Facilities, docyments uranium and some radionuclide releases to the air and water and solid waste burial. 18 The Report of the Joint Task Force on Uranium Recycle Materials Processing documents the results of a Joint Task Force that was assembled by the Department of Energy to stmdy past and current practices relating to the processing of uranium recycle materials. 99 The Oak Ridge Dose Reconstruction Team performed a historical review of air- and water-release data, including health physics and industrial hygiene reports, stack monitoring data, accident and investigation reports, logbooks, and procedures for the period 1944 through 1988. Two reports of the Oak Ridge Dose Reconstruction Project provide release data: Vol.5, The Report of Project Task 6: Uranium Releases from the Oak Ridge Reservation-A Review of the Quality of Historical Effluent Monitoring Data and a Screening Evaluation of Potential Off-Site Exposures, issued July 1999, provides airborne uranium release estimates for the Y-12 Complex (1944-1988) and a comparison to data previously published by DOE (1944-1995), and Vol.6, The Report of Project Task 7: Screening-Level Evaluation of Additional Potential Materials of Concern, July 1999, provides information for additional radionuclides, including Y-12 Complex estimated air- and water-release data for $\mathrm{Np}$ (1953-1995) and estimated air-release data for Tc.

Analytical data for TRU and fission products in material releases associated with RU processing are a combination of specific analytical data and derived or generated data. A discussion of the results and analytical data are presented in Section 2.5 of this report.

\footnotetext{
${ }^{66}$ U.S. Department of Energy, Preliminary Draft Site-Wide Environmental Impact Statement for the Oak Ridge Y-12 Plant, April 2000.

${ }^{67}$ Ibid.

${ }^{68}$ U.S. Department of Energy, Historical Radionuclide Releases from Current DOE Oak Ridge Operations Office Facilities, May 1988.

${ }^{69}$ Egli et al., Report of the Joint Task Force on Uranium Recycle Materials Processing, 1985.
} 
Since 1985, the Y-12 Complex has routinely performed radiological monitoring of the surface water as part of the plant NPDES permit. The continued monitoring of contaminants and the associated environmental impact is managed under the Y-12 Complex Environmental Compliance Program. A Radiological Monitoring Plan (Y/TS-1704) is in place to address compliance with DOE Orders and the NPDES permit. Under the program, effluent monitoring is performed at treatment facilities, other point and area source discharges, and in-stream locations. The radiological data obtained are evaluated and submitted to the Tennessee Department of Environment and Conservation on a quarterly basis..$[0]$ Radiological parameters monitored at the Y-12 Complex include the following:

- uranium isotopes $\left({ }^{238} \mathrm{U},{ }^{235} \mathrm{U},{ }^{234} \mathrm{U}\right.$, total $\mathrm{U}$, and wt \% of $\left.{ }^{235} \mathrm{U}\right)$

- fission and activation products $\left({ }^{90} \mathrm{Sr}\right.$, tritium, ${ }^{99} \mathrm{Tc}$, and $\left.{ }^{137} \mathrm{Cs}\right)$

- transuranic isotopes $\left({ }^{241} \mathrm{Am},{ }^{237} \mathrm{~Np},{ }^{238} \mathrm{Pu}\right.$, and $\left.{ }^{239,}{ }^{240} \mathrm{Pu}\right)$

- other isotopes of interest ${ }^{232} \mathrm{Th},{ }^{230} \mathrm{Th},{ }^{288} \mathrm{Th},{ }^{226} \mathrm{Ra}$, and $\left.{ }^{228} \mathrm{Ra}\right)$

\subsection{ANALYTICAL RESULTS FOR TRU ELEMENTS AND FISSION PRODUCTS IN RECYCLED URANIUM MATERIALS SHIPPED FROM THE Y-12 COMPLEX}

As discussed in Section 4.3 of this document, both RADCON-type and product-type standards/specifications were developed and used at the Y-12 Complex to address radiological safety problems associated with the presence of TRU and fission products in RU materials received, processed, and shipped. Under the successive oversight of the AEC, ERDA, and DOE, the formality of the associated documentation was increased, especially with the explicit RADCON-type specifications. However, either through product specifications, RADCON-type specifications, or a combination of both, limits were placed on acceptable levels of TRU and fission products in RU received and processed for shipment from the beginnings of the RU program in 1953.

\subsubsection{Recycled Enriched Uranium Metal for the Savannah River Site (SRS)}

RU from SRS was processed at the Y-12 Complex by solvent extraction purification of impure uranyl nitrate solution, evaporation, denitration by thermal decomposition to $\mathrm{UO}_{3}$, hydrogen reduction to $\mathrm{UO}_{2}$, hydrofluorination to $\mathrm{UF}_{4}$, and bomb reduction to produce uranium metal buttons. Metal buttons were broken, packaged, and returned to SRS along with some additional high-assay material for fabrication into new fuel elements. This processing of SRS RU continued until February 1989. Not all of the material was returned to SRS, and some remains in inventory at the Y-12 Complex today. At the plant, metal buttons were batched, with each product batch containing from one to four metal buttons. Composite samples were taken from each batch and analyzed for uranium isotopes. Additional analysis, including analysis for TRU and fission products, was performed on one out of every ten batches.

\footnotetext{
${ }^{70}$ Lockheed Martin Energy Systems, Inc., Transuranic Hazard Assessment at the Y-12 Plant; July 29, 1997.

${ }^{71}$ U.S. Department of Energy, Preliminary Draft Site-Wide Environmental Impact Statement for the Oak Ridge Y-12 Plant, April 2000.
} 
As mentioned in Section 4.3 of this document, the specification for recycled enriched uranium for SRS is denoted as SRP-EMS-97 in a 1979 letter and as EM Specification 97 in a 1981 letter and a 1988 (handwritten label) photocopy. The limit, "total alpha activity from neptunium and plutonium shall not exceed $0.1 \mu \mathrm{Ci} / \mathrm{g} \mathrm{U}$ " does not change over this nine-year period. The limit on Tc is not explicitly spelled out but follows from the specification that the gamma activity from individual radionuclides shall not exceed $0.05 \mu \mathrm{Ci} / \mathrm{g} \mathrm{U}$ for any radionuclide other than $\mathrm{Ce}, \mathrm{Ru}, \mathrm{Cs}$, or ${ }^{95} \mathrm{Zr}-\mathrm{Nb}$. This limit also remains unchanged over the nine-year time period. As discussed in Section 4.3 of this document, the ${ }^{236} \mathrm{U}$ content was not specified for the recycled enriched uranium because it was determined by the supplier of the RU in solution form, SRS, which was also the customer for the metal product. Also as discussed in Section 4.3, the presence of the ${ }^{236} \mathrm{U}$ in the recycled uranium was accounted for in the existing U limits at the Y-12 Complex, and presumably, at SRS.

In Table 4.8.1, analytical data summaries are given for shipments of uranium metal to SRS in the years 1977 through 1982 (incidental files), and for recycled enriched uranium metal prepared for SRS in the years 1982 through 1988 but not shipped. ${ }^{2}$ It is not clear from the incidental files whether the shipments to SRS included Oralloy as well as recycled enriched uranium metal. No data on technetium is on hand for any of the cases, although a limit can be inferred from the specifications. Also, at this time, data for ${ }^{236} \mathrm{U}$ is on hand only for the unshipped recycled metal.

Table 4.8.1 Analytical Data for Recycled Enriched Uranium Metal for SRS

\begin{tabular}{|c|c|c|c|}
\hline & Pu + Np Average & $\begin{array}{c}\text { Tc Average (Unlisted } \\
\text { Individual Radio- } \\
\text { Nuclide Limit) }\end{array}$ & 236 U Average \\
\hline Limit & $\mathbf{0 . 1} \boldsymbol{\mu C i / g ~ U}$ & $\mathbf{0 . 0 5} \mathbf{\mu C i} \mathbf{g ~ U}$ & Not Applicable \\
\hline 1977 Shipments & $0.028 \pm 0.023$ & na & na \\
\hline 1978 Shipments & $0.015 \pm 0.015$ & na & na \\
\hline 1979 Shipments & $0.007 \pm 0.004$ & na & na \\
\hline 1980 Shipments & $0.005 \pm 0.006$ & na & na \\
\hline 1981 Shipments & 0.009 & na & na \\
\hline
\end{tabular}

From these data it is seen that the $\mathrm{Pu}+\mathrm{Np}$ specification is well satisfied for both the shipped and unshipped (stored) recycled enriched uranium metal.

\subsubsection{Y-12 Complex Metal Product Derived from Savannah River Recycled Uranium}

Table 4.8-2 summarizes results of uranium isotopic analysis for samples of 561 metal button batches and results of the additional analysis performed on 45 batches from the one in ten sampling of metal button batches produced from 1986 to 1989.

For the sample population of 45 metal button batches, Pu ranged from $160 \mathrm{dpm} / \mathrm{g} \mathrm{U}$ $(0.00007 \mu \mathrm{Ci} / \mathrm{g} \mathrm{U})$ to $21,100 \mathrm{dpm} / \mathrm{g} \mathrm{U}(0.0095 \mu \mathrm{Ci} / \mathrm{g} \mathrm{U})$ with an average result of 4,188 $\mathrm{dpm} / \mathrm{g} \mathrm{U}(0.0019 \mu \mathrm{Ci} / \mathrm{g} \mathrm{U}) . \mathrm{Np}$ ranged from $1,090 \mathrm{dpm} / \mathrm{g} \mathrm{U}(0.0005 \mu \mathrm{Ci} / \mathrm{g} \mathrm{U})$ to 39,100

\footnotetext{
${ }^{72}$ Lockheed Martin Energy Systems, Grouping Uranium Metal Button for the Off-Specification Fuel Project, 1999.
} 
Table 4.8-2 Summarized Laboratory Analysis Results for Metal Buttons Produced at the Y-12 Complex from Savannah River Recycled Uranium

\begin{tabular}{|c|c|c|c|c|c|c|c|}
\hline $\begin{array}{c}\text { SRP Metal Button } \\
1986-1989\end{array}$ & $\underset{\mathbf{N}}{\text { Valid }}$ & Mean & $\begin{array}{l}\text { Confid. } \\
-95.000 \%\end{array}$ & $\begin{array}{l}\text { Confid. } \\
+95.000 \%\end{array}$ & Minimum & Maximum & Std. Dev. \\
\hline$\%{ }^{234} \mathrm{U}$ & 561 & 1.2748 & 1.2698 & 1.2797 & 0.9800 & 1.500 & 0.0597 \\
\hline$\%{ }^{235} U$ & 561 & 55.0204 & 54.5074 & 55.5334 & 45.1900 & 87.670 & 6.1859 \\
\hline$\%{ }^{236} \mathrm{U}$ & 561 & 27.6182 & 27.2401 & 27.9961 & 3.9500 & 36.410 & 4.5569 \\
\hline$\%{ }^{238} \mathrm{U}$ & 561 & 16.0866 & 15.9480 & 16.2252 & 7.4000 & 20.160 & 1.6714 \\
\hline$\cup g / g$ & 560 & 0.9994 & 0.9994 & 0.9994 & 0.9935 & 0.999 & 0.0004 \\
\hline${ }^{237} \mathrm{~Np} \mathrm{dpm}$ & 48 & 7509.2083 & 5519.6134 & 9498.8032 & 1090.0000 & 39100.000 & 6851.9362 \\
\hline Pu dpm & 45 & 4188.0000 & 2830.8031 & 5545.1969 & 160.0000 & 21100.000 & 4517.4654 \\
\hline Total TRU dpm & 45 & 12170.2000 & 9735.0960 & 14605.3040 & 1440.0000 & 40600.000 & 8105.3076 \\
\hline Alpha Ratio & 43 & 0.0010 & & & 0.0010 & 0.001 & 0 \\
\hline${ }^{228} \mathrm{Th}$ dpm & 45 & 65243.9330 & 54165.8270 & 76322.039 & 3950.0000 & 195000.000 & 36873.767 \\
\hline${ }^{137} \mathrm{Cs} \mu \mathrm{Ci}$ & 45 & 0.0010 & & & 0.0010 & 0.001 & 0 \\
\hline${ }^{95} \mathrm{Zr}-\mathrm{Nb} \mu \mathrm{Ci}$ & 45 & 0.0017 & 0.0011 & 0.0023 & 0.0010 & 0.011 & 0.0020 \\
\hline${ }^{106} \mathrm{Ru} \mu \mathrm{Ci}$ & 45 & 0.0012 & 0.0010 & 0.0013 & 0.0010 & 0.003 & 0.0004 \\
\hline${ }^{144} \mathrm{Ce} \mu \mathrm{Ci}$ & 45 & 0.0028 & 0.0020 & 0.0036 & 0.0010 & 0.009 & 0.0027 \\
\hline Total $\mu \mathrm{Ci}$ & 45 & 0.0051 & 0.0038 & 0.0064 & 0.0010 & 0.014 & 0.0043 \\
\hline${ }^{232} \mathrm{U} / \mu \mathrm{g} U$ & 45 & 1.0007 & 0.9481 & 1.0532 & 0.5610 & 1.427 & 0.1749 \\
\hline 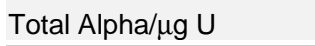 & 45 & 219.3498 & 215.6265 & 223.0731 & 196.4200 & 258.340 & 12.3932 \\
\hline Beta Ratio & 45 & 0.8898 & 0.8285 & 0.9510 & 0.1950 & 1.156 & 0.2037 \\
\hline
\end{tabular}

$\mathrm{dpm} / \mathrm{g} \mathrm{U}(0.0176 \mu \mathrm{Ci} / \mathrm{g} \mathrm{U})$ with an average result of $7,509 \mathrm{dpm} / \mathrm{g} \mathrm{U}(0.0035 \mu \mathrm{Ci} / \mathrm{g} \mathrm{U})$. Comparing the $\mathrm{Pu}$ and $\mathrm{Np}$ result averages of these metal buttons with the data for the 1984 to 1986 uranyl nitrate solution receipts given in Section 4.4.1.1, Table 4.4-1, it is seen that the $\mathrm{Pu}$ and $\mathrm{Np}$ in product buttons is less than that in the solution receipts. The average $\mathrm{Pu}$ result in the metal product is $46 \%$ of that for the solution (0.0019 compared to 0.0041) and the Np results average is $14 \%$ of that for the solution (0.0035 compared to 0.0247). In Figure 4.8-1, the combined $\mathrm{Np}, \mathrm{Pu}$, and $\mathrm{Th}$ values for these button samples are shown compared to the post-1986 non-uranium alpha specification limit of $140,000 \mathrm{dpm} / \mathrm{g} \mathrm{U}$ and the $200,000 \mathrm{dpm} / \mathrm{g}$ U limit in effect prior to 1986.

For the sample population of 561 metal button batches (circa 1986 - 1989), ${ }^{236} \mathrm{U}$ ranged from 3.95 to $36.41 \mathrm{wt} \% \mathrm{U}$ and ${ }^{235} \mathrm{U}$ ranged from 45.19 to $87.67 \mathrm{wt} \% \mathrm{U}$. The relationship of ${ }^{235} \mathrm{U}$ and ${ }^{236} \mathrm{U}$ results is plotted in Figure 4.8-2. The data show maximum, minimum, and average cases with respect to ${ }^{236} \mathrm{U}$ as follows:
Maximum ${ }^{236} \mathrm{U}$ Case:
$36.41 \%{ }^{236} \mathrm{U}$ and $45.19 \%{ }^{235} \mathrm{U}$
Minimum ${ }^{236} \mathrm{U}$ Case:
$3.95 \%{ }^{236} \mathrm{U}$ and $87.67 \%{ }^{235} \mathrm{U}$
Average ${ }^{236} \mathrm{U}$ Case:
$27.62 \%{ }^{236} \mathrm{U}$ and $55.02 \%{ }^{235} \mathrm{U}$ 


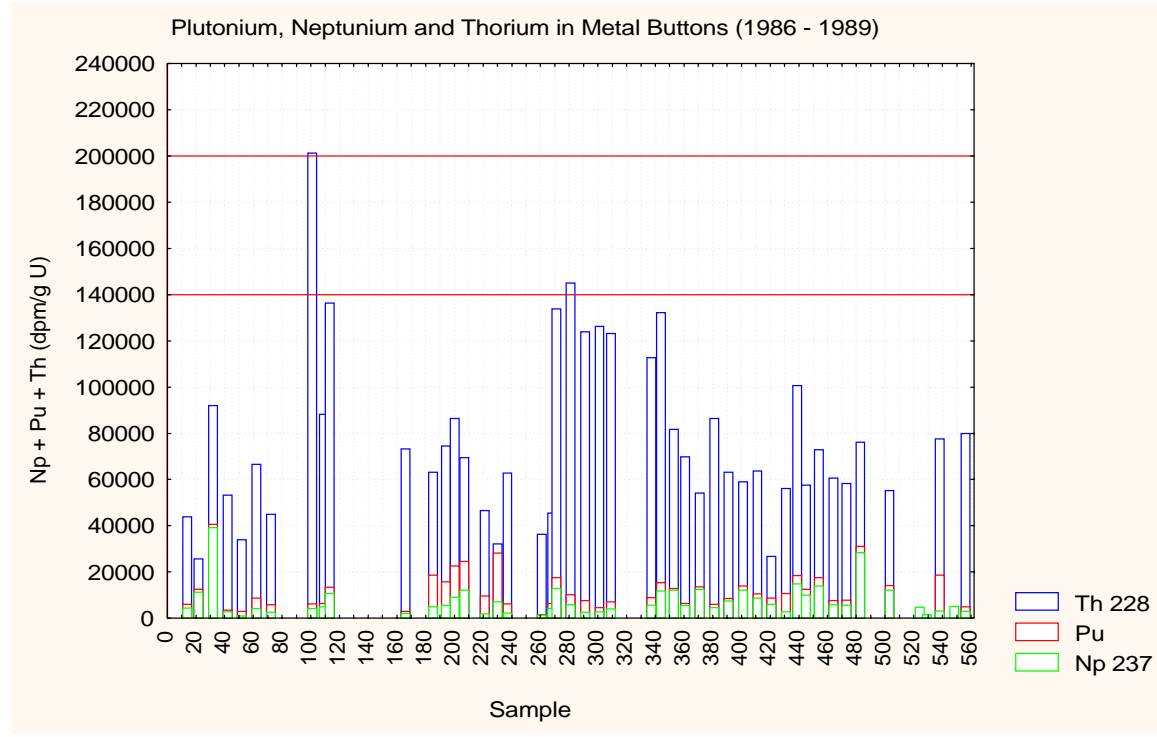

Fig. 4.8-1 Combined Values of $\mathrm{Pu}, \mathrm{Np}$ and Th in Metal Buttons Produced from Savannah River Recycled Uranium.

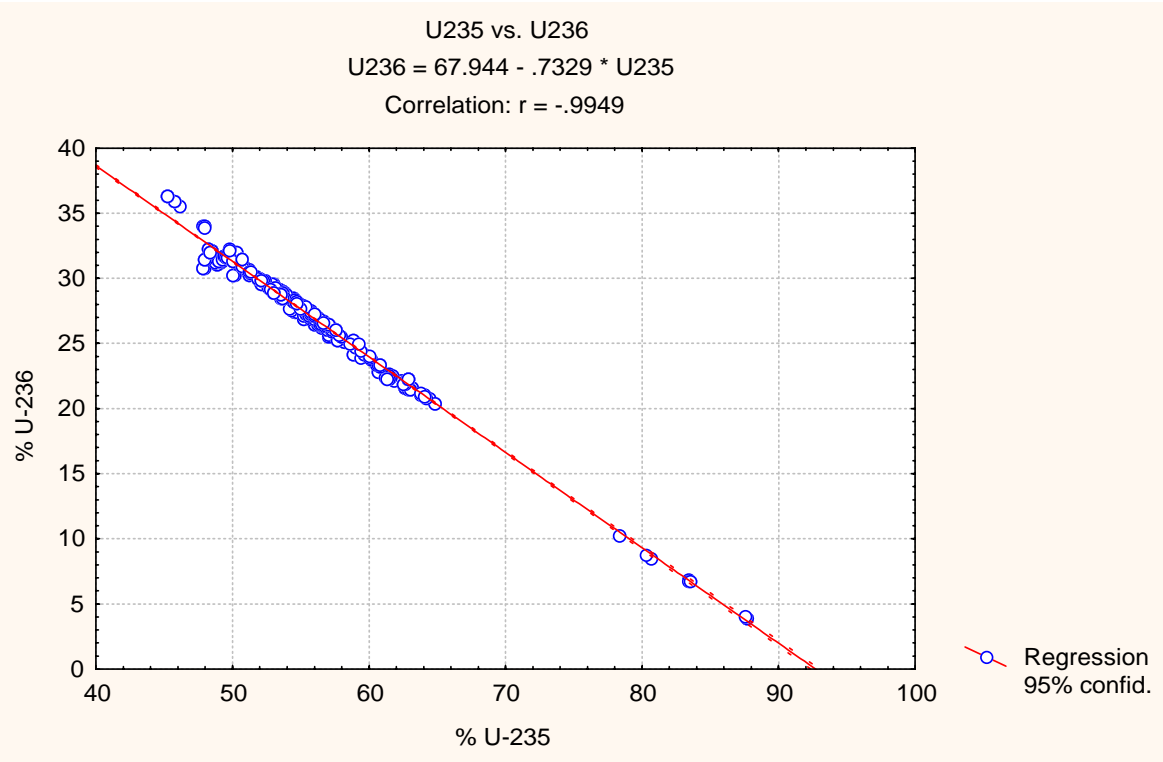

Fig. 4.8-2 Uranium-236 Content of Metal Buttons Produced at the Y-12 Complex from Savannah River Recycled Uranium.

Analytical data for five metal button product batches produced in November and December 1984 are summarized in Table 4.8-3. Comparing the $\mathrm{Pu}$ and $\mathrm{Np}$ result averages with the data for the 1984 to 1986 uranyl nitrate solution receipts given in Section 4.4.1.1, Table 4.4-1, it is seen that the $\mathrm{Pu}$ and $\mathrm{Np}$ in product buttons is less than that in the solution receipts. The $\mathrm{Pu}$ average for the metal product material is $25 \%$ of that for the solution 
material (0.001 compared to 0.004) and the Np average is $13 \%$ of that for the solution (0.0032 compared to 0.0247$)$.

Table 4.8-3 Summarized Laboratory Analysis Results for Metal Buttons Produced at the Y-12 Complex from Savannah River Recycled Uranium in 1984

\begin{tabular}{|c|c|c|c|c|c|}
\hline SRP 14201984 & Valid N & Mean & Minimum & Maximum & Std. Dev. \\
\hline${ }^{237} \mathrm{~Np} \mu \mathrm{Ci} / \mathrm{g} U$ & 5 & 0.0032 & 0.001 & 0.006 & 0.0019235 \\
\hline${ }^{238,240} \mathrm{Pu} \mu \mathrm{Ci} / \mathrm{g} \mathrm{U}$ & 5 & 0.0010 & 0.001 & 0.001 & 0 \\
\hline${ }^{228} \mathrm{Th} \mu \mathrm{Ci} / \mathrm{g} \mathrm{U}$ & 5 & 0.0202 & 0.016 & 0.031 & 0.0061400 \\
\hline Total Actinides $\mu \mathrm{Ci} / \mathrm{g} U$ & 5 & 0.0238 & 0.017 & 0.038 & 0.0082280 \\
\hline Alpha Ratio & 5 & 0.2670 & 0.194 & 0.418 & 0.0872525 \\
\hline${ }^{137} \mathrm{Cs} \mu \mathrm{Ci} / \mathrm{g} \mathrm{U}$ & 5 & 0.0010 & 0.001 & 0.001 & 0 \\
\hline${ }^{95} \mathrm{Zr}-\mathrm{Nb} \mu \mathrm{Ci} / \mathrm{g} \mathrm{U}$ & 5 & 0.0024 & 0.001 & 0.006 & 0.0021909 \\
\hline${ }^{106} \mathrm{Ru} \mu \mathrm{Ci} / \mathrm{g} U$ & 5 & 0.0010 & 0.001 & 0.001 & 0 \\
\hline${ }^{144} \mathrm{Ce} \mu \mathrm{Ci} / \mathrm{g} \mathrm{U}$ & 5 & 0.0024 & 0.001 & 0.006 & 0.0021909 \\
\hline${ }^{232} \mathrm{U} \mu \mathrm{Ci} / \mathrm{g} \mathrm{U}$ & 5 & 0.6356 & 0.499 & 0.847 & 0.1475290 \\
\hline Total U Alpha dpm/ug U & 5 & 213.7500 & 210.130 & 219.560 & 3.9529989 \\
\hline$\%{ }^{234} U$ & 5 & 1.2880 & 1.270 & 1.300 & 0.0109545 \\
\hline$\%^{235} \mathrm{U}$ & 5 & 59.9840 & 54.860 & 63.050 & 3.8732260 \\
\hline$\%{ }^{236} \mathrm{U}$ & 5 & 24.5360 & 22.780 & 27.870 & 2.3893786 \\
\hline$\%^{238} \mathrm{U}$ & 5 & 14.1920 & 12.880 & 15.970 & 1.4942791 \\
\hline Beta Ratio & 5 & 0.7766 & 0.718 & 0.842 & 0.0493943 \\
\hline
\end{tabular}

\subsubsection{Y-12 Complex Metal Product Derived from ICPP Recycled Uranium}

Like the Savannah River RU, processing of ICPP RU materials was conducted in Buildings 9212 and 9206. Uranyl nitrate solutions were received at Building 9212 and transferred to Building 9206. Uranium trioxide solids were dissolved in nitric acid to yield uranyl nitrate solution. The uranyl nitrate solution was processed through solvent extraction, evaporation, denitration by thermal decomposition to $\mathrm{UO}_{3}$, hydrogen reduction to $\mathrm{UO}_{2}$, hydrofluorination to $\mathrm{UF}_{4}$, and bomb reduction to produce uranium metal buttons. Raffinate from SRS and ICPP material was isolated at Building 9206 and trucked to Building 9212 where it was mixed with 9212 raffinate and fed to the bioreactors. Sludge went to the S-3 Ponds or West End Treatment Facility (WETF). The metal buttons produced at the Y-12 Complex from ICPP RU were shipped along with the SRS material product buttons to SRS where they were fabricated into driver fuel for the Savannah River production reactors. Because the ICPP material was of higher ${ }^{235} \mathrm{U}$ enrichment, it was blended with the SRS material to produce a mixture of higher enrichment. Of the 9.6 MT of RU metal buttons remaining at the Y-12 Complex today, 71 buttons were made from Idaho RU and 2,074 were made from SRS RU. Previous efforts to locate analytical data associated with the ICPP product buttons were unsuccessful,, 3 and no analytical information, beyond that summarized in the 1983 report of the annual report series discussed earlier in Section 4.5.1, was found

\footnotetext{
${ }^{73}$ Lockheed Martin Energy Systems, Grouping Uranium Metal Buttons for the Off-Specification Fuel Project, September 17, 1999
} 
during this current effort. The 1983 summarized results shown in Table 4.5-6 included the following information on 5 samples of the Y-12 Complex product from ICPP material:

- Average Alpha Ratio $\quad .10$

- Average Beta Ratio $\quad .60$

- Total Fission Products $\quad .001 \mu \mathrm{Ci} / \mathrm{g} \mathrm{U}$ 
This page intentionally left blank. 


\subsection{MASS BALANCE ACTIVITIES}

\subsection{ESTIMATED OVERALL MASS BALANCE OF RECYCLED URANIUM}

This chapter combines the gross quantities of enriched RU shipped to/from the Y-12 Complex (Chapter 3) with the constituent analytical data (Chapter 4) and process engineering judgment (Chapter 2) to provide an estimate of the actual quantities of RU and the constituents of concern that passed through the Y-12 Complex. These mass flows are presented in a framework that balances quantities received at the plant against quantities shipped, quantities contained in waste, and those remaining in inventory on-site.

As noted in Chapter 2, only RU materials that would have been chemically processed through 9212 or 9206 (only highly enriched RU) are addressed in the analysis of mass balance activities. RU below this assay range that was shipped to the Y-12 Complex was eliminated from further consideration, as discussed in Chapter 2, in accordance with the methodology established for the RU mass balance project.

\subsubsection{Uranium}

The total flow of highly enriched RU into the Y-12 Complex, as presented in Chapter 3, was determined to be 150.9 MTU, from years 1953 through 1999. This material was received from the Savannah River Site (125.2 MTU) and the Idaho Chemical Processing Plant (25.7 MTU).

The material was received in the form of uranyl nitrate solution, uranium trioxide $\left(\mathrm{UO}_{3}\right)$, uranium/aluminum metal, miscellaneous floor sweepings, and casting dross. Quantities received, shipped, and currently in inventory for the Y-12 Complex are summarized in Table 5.1-1.

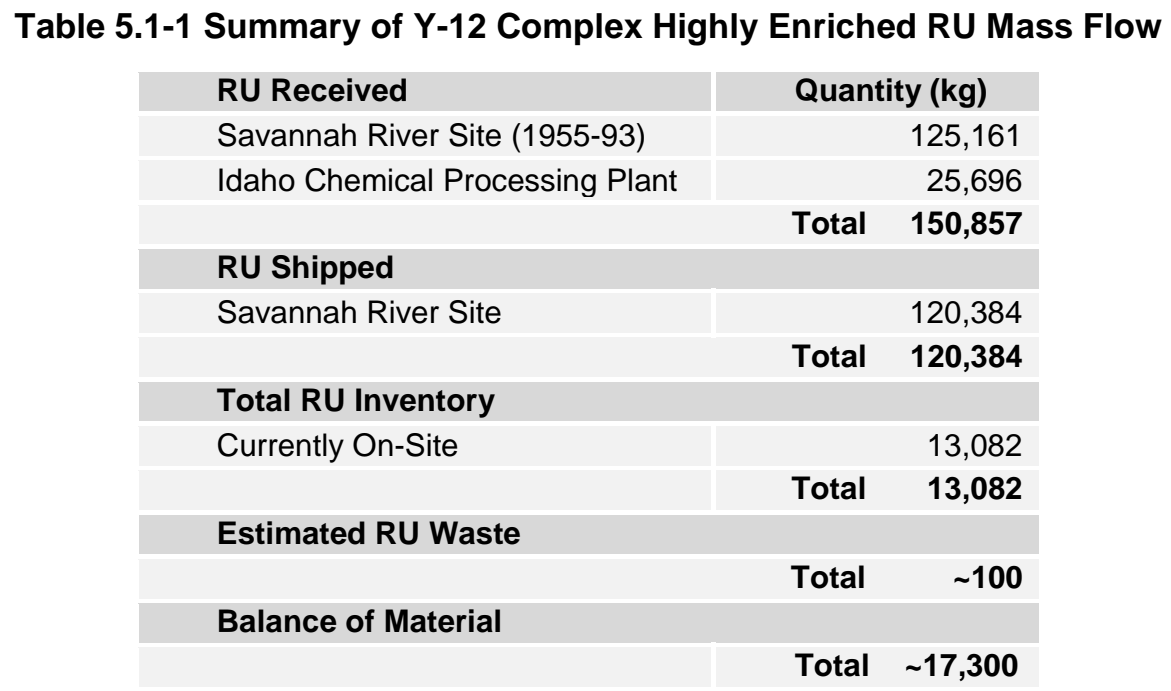

Most of this material was processed through the 9212 and/or 9206 facilities to produce metal buttons for shipment to SRS where they were used in the fabrication of reactor fuel rods. The process employed at the Y-12 Complex was basically that of nitric acid dissolution, solvent 
extraction of uranyl nitrate to separate the uranium from aqueous solution through preferential dissolution and leaving impurities behind in a raffinate stream, denitration to uranium oxide, reduction and hydrofluorination to $\mathrm{UF}_{4}$, and reduction to uranium metal. The raffinate was discharged as a waste directly to the S-3 Ponds until the mid-1980s, when the WETF was constructed. After that time, the raffinate was discharged to the WETF.

The remaining Y-12 Complex on-site RU inventory is primarily in the form of metal buttons. Some unprocessed U-Al metal scrap, casting dross, and floor sweepings also remain and are slated for processing through Nuclear Fuel Services (NFS) through contracts managed under the DOE Central Scrap Management Office for uranium. Residual amounts of RU were buried with process solid waste as unleached oxide.

\subsubsection{Plutonium and Neptunium}

The availability of site-specific RU data at the Y-12 Complex, beyond that of gross material receipts and shipments, was limited for SRS material and was available only from Idaho National Engineering and Environmental Laboratory for ICPP materials. As a result, the RU mass balance report prepared by the ICPP was used to determine mass quantities of the constituents of concern that were shipped to the Y-12 Complex from that site, while Y-12 Complex data were used for SRS. As is evident in Table 5.1-1, the SRS material constituted the overwhelming portion of RU processed at the Y-12 Complex.

As reported in Chapter 4, data on plutonium and neptunium constituent levels in RU were found in a variety of forms and locations. Files/records were predominantly obtained from individual personal archives (often in boxes from retired employees) and included actual laboratory reports. In addition, C.M. West (retiredY-12 Complex Health Physicist) developed a presentation for the Department of Energy in 1985 ${ }^{1}$ that spoke in detail to the issues surrounding RU material at the Y-12 Complex, including constituent levels and potential worker exposures. Mr. West had been employed at the Y-12 Complex during most of the years that RU was processed and possessed a working knowledge of the materials and processes, in addition to his radiological expertise.

Most data reported the material alpha ratio and the associated activities $(\mu \mathrm{Ci} / \mathrm{g} \mathrm{U})$ for $\mathrm{Pu}, \mathrm{Np}$, and $\mathrm{Th}$ ). Where actual laboratory data or laboratory reports were available, they were used as the primary data sources for the respective period of time.

The individual constituent activity in the RU was combined with the constituent specific activity to arrive at the mass fractions (parts per billion - ppb) for $\mathrm{Pu}$ and $\mathrm{Np}$.

A representative $\mathrm{Pu}$ specific activity, which is dependent upon the isotopic abundances of plutonium in the material, had to be used. Mr. West refers to a value of $2.77 \times 10^{13} \mathrm{dpm} / \mathrm{g} \mathrm{U}$, based upon amixture of $75 \%{ }^{238} \mathrm{Pu}$ and $25 \%{ }^{239} \mathrm{Pu}$. Information subsequent to the West presentation ${ }^{2}$ suggests that a more representative value for production reactor grade plutonium would be $3.1 \times 10^{13} \mathrm{dpm} / \mathrm{g} \mathrm{Pu}$, based on isotopic abundances of $84 \%{ }^{238} \mathrm{Pu}, 14 \%{ }^{239} \mathrm{Pu}$, and $2 \%$ ${ }^{240} \mathrm{Pu}$. This more recent figure was used for this report. For the ${ }^{237} \mathrm{~Np}$ isotope, the value of $1.57 \times 10^{9} \mathrm{dpm} / \mathrm{g} \mathrm{Np}$ was used.

\footnotetext{
${ }^{1}$ West, C. M., "Radioactive Contaminants in Uranium Reactor Returns at the Oak Ridge Y-12 Plant," 1985.

2 "Some Early Results Describing Plutonium Contamination of Highly Enriched Uranium (HEU)," correspondence, J. E. Vath, September 8, 1999.
} 


\subsubsection{Receipts}

Data for receipts of Savannah River material were available from a variety of sources for years 1977 through 1986. Those years prior to 1977 and subsequent to 1986 (through 1989) were much more limited in the availability of representative data. As a result, the years 1977 through 1984 were used as a base period for extrapolation to values representative of other periods of time where data was scarce or unavailable. Consequently, this period of time is discussed first, rather than the normal chronological presentation.

The $\mathrm{Pu}$ and $\mathrm{Np}$ constituent quantities by year from Savannah River are presented in Table 5.1-2. Table 5.1-3 presents the corresponding quantities for RU from ICPP.

\section{7 through 1986}

Data for this timeframe were predominantly in the form of laboratory reports and/or logbooktype records maintained by the operating group(s). The latter were often chronological listings of the individual lab results routinely received and recorded as a normal part of the operation.

Data from the various sources were generally found to be in good agreement, and the West presentation provided similar results. The data typically included the date, material code/description, identification numbers, constituent activities, alpha ratio, beta ratio, and total uranium alpha. Typically, several individual analyses or data sets were available for each year. The parameters of interest from this raw data were averaged to arrive at representative values for each year and subsequently applied to incoming material quantities to determine annual quantities of $\mathrm{Pu}$ and $\mathrm{Np}$.

\section{3 through 1976, and 1987 through 1989}

There were no data available at the Y-12 Complex that directly represented these periods of time. A review of available information (including the SRS Mass Balance Report ${ }^{6}$, however, did not suggest or report any changes in operations or processes at SRS that would be expected to result in significant changes in the constituent levels in materials coming to the Y-12 Complex. The PUREX process continued to be employed at SRS until 1992. Consequently, the average values of the $\mathrm{Pu}(0.004 \mu \mathrm{Ci} / \mathrm{g} \mathrm{U})$ and $\mathrm{Np}(0.016 \mu \mathrm{Ci} / \mathrm{g} \mathrm{U})$ activities from the years 1977 through 1984 were applied to each of these years.

\section{4 through 1972}

The C. M. West presentation reported an average alpha ratio for each of nine different intervals during this time period (December 1964 through May of 1972). Additional information related to this data is included in Section 4.4.1.1. The presentation did not, however, report the corresponding constituent activities $(\mu \mathrm{Ci} / \mathrm{g} \mathrm{U})$ or fraction of the alpha ratio due to each constituent.

To arrive at representative activity levels for $\mathrm{Pu}$ and $\mathrm{Np}$, an average alpha ratio was calculated from the West presentation for 1964 through 1972. The average values for Pu and Np activities from the base period were then adjusted by the fraction of the average alpha ratio from each period of time, 0.43 (1964 through 1972) and 0.26 (1977 through 1986).

\footnotetext{
${ }^{3}$ SRS, Historical Generation and Flow of Recycled Uranium at the Savannah River Site, ESH-PEQ-2000-00059.
} 
Table 5.1-2 SRS Receipts and Constituent Quantities by Year

\begin{tabular}{|c|c|c|c|c|c|c|c|c|c|c|}
\hline & \multirow[t]{2}{*}{ Period } & \multirow{2}{*}{$\begin{array}{c}\text { Receipts } \\
\text { kg }\end{array}$} & \multicolumn{3}{|c|}{$\mathrm{Pu}$} & \multicolumn{3}{|c|}{ Np } & \multicolumn{2}{|c|}{ Tc } \\
\hline & & & $\begin{array}{l}\text { Average } \\
(\mu \mathrm{Ci} / \mathrm{g} \mathrm{U})\end{array}$ & $\mathrm{ppb}$ & g & $\begin{array}{l}\text { Average } \\
(\mu \mathrm{Ci} / \mathrm{g} \mathrm{U})\end{array}$ & ppb & g & ppm & g \\
\hline & \multicolumn{10}{|l|}{1953} \\
\hline & \multicolumn{10}{|l|}{1954} \\
\hline & 1955 & 2 & 0.007 & 0.48 & 0.000 & 0.027 & 37,474 & 0.1 & 114 & 0.2 \\
\hline & \multicolumn{10}{|l|}{1956} \\
\hline & 1957 & 3 & 0.007 & 0.48 & 0.000 & 0.027 & 37,474 & 0.1 & 114 & 0.3 \\
\hline & 1958 & 18 & 0.007 & 0.48 & 0.000 & 0.027 & 37,474 & 0.7 & 114 & 2.1 \\
\hline & 1959 & 149 & 0.007 & 0.48 & 0.000 & 0.027 & 37,474 & 5.6 & 114 & 17.0 \\
\hline & 1960 & 6,235 & 0.007 & 0.48 & 0.003 & 0.027 & 37,474 & 233.7 & 114 & 710.8 \\
\hline & 1961 & 2,058 & 0.007 & 0.48 & 0.001 & 0.027 & 37,474 & 77.1 & 114 & 234.6 \\
\hline & 1962 & 2,397 & 0.007 & 0.48 & 0.001 & 0.027 & 37,474 & 89.8 & 114 & 273.3 \\
\hline & 1963 & 6,446 & 0.007 & 0.48 & 0.003 & 0.027 & 37,474 & 241.6 & 114 & 734.8 \\
\hline \multirow{13}{*}{ 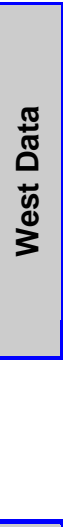 } & 1964 & 2,978 & 0.007 & 0.48 & 0.001 & 0.027 & 37,474 & 111.6 & 114 & 339.5 \\
\hline & 1965 & 3,552 & 0.007 & 0.48 & 0.002 & 0.027 & 37,474 & 133.1 & 114 & 404.9 \\
\hline & 1966 & 3,700 & 0.007 & 0.48 & 0.002 & 0.027 & 37,474 & 138.7 & 114 & 421.8 \\
\hline & 1967 & 2,502 & 0.007 & 0.48 & 0.001 & 0.027 & 37,474 & 93.8 & 114 & 285.2 \\
\hline & 1968 & 2,109 & 0.007 & 0.48 & 0.001 & 0.027 & 37,474 & 79.0 & 114 & 240.4 \\
\hline & 1969 & 4,090 & 0.007 & 0.48 & 0.002 & 0.027 & 37,474 & 153.3 & 114 & 466.3 \\
\hline & 1970 & 2,060 & 0.007 & 0.48 & 0.001 & 0.027 & 37,474 & 77.2 & 114 & 234.8 \\
\hline & 1971 & 3,500 & 0.007 & 0.48 & 0.002 & 0.027 & 37,474 & 131.2 & 114 & 399.0 \\
\hline & 1972 & 4,701 & 0.007 & 0.48 & 0.002 & 0.027 & 37,474 & 176.2 & 114 & 535.9 \\
\hline & 1973 & 5,070 & 0.004 & 0.29 & 0.001 & 0.016 & 22,539 & 114.3 & 114 & 578.0 \\
\hline & 1974 & 4,581 & 0.004 & 0.29 & 0.001 & 0.016 & 22,539 & 103.3 & 114 & 522.2 \\
\hline & 1975 & 5,131 & 0.004 & 0.29 & 0.001 & 0.016 & 22,539 & 115.6 & 114 & 584.9 \\
\hline & 1976 & 4,312 & 0.004 & 0.29 & 0.001 & 0.016 & 22,539 & 97.2 & 114 & 491.6 \\
\hline \multirow{10}{*}{ 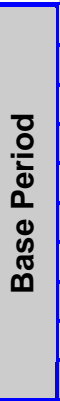 } & 1977 & 4,505 & 0.014 & 0.97 & 0.004 & 0.035 & 48,880 & 220.2 & 114 & 513.6 \\
\hline & 1978 & 2,078 & 0.003 & 0.18 & 0.000 & 0.007 & 9,108 & 18.9 & 114 & 236.9 \\
\hline & 1979 & 4,576 & 0.003 & 0.22 & 0.001 & 0.021 & 29,767 & 136.2 & 114 & 521.7 \\
\hline & 1980 & 1,489 & 0.001 & 0.09 & 0.000 & 0.006 & 8,408 & 12.5 & 114 & 169.7 \\
\hline & 1981 & 4,911 & 0.004 & 0.30 & 0.001 & 0.008 & 11,695 & 57.4 & 114 & 559.9 \\
\hline & 1982 & 5,719 & 0.002 & 0.13 & 0.001 & 0.004 & 5,561 & 31.8 & 114 & 652.0 \\
\hline & 1983 & 6,649 & 0.002 & 0.12 & 0.001 & 0.006 & 8,162 & 54.3 & 114 & 758.0 \\
\hline & 1984 & 4,870 & 0.004 & 0.30 & 0.001 & 0.025 & 34,603 & 168.5 & 114 & 555.2 \\
\hline & 1985 & 8,243 & 0.004 & 0.30 & 0.002 & 0.025 & 34,603 & 285.2 & 114 & 939.7 \\
\hline & 1986 & 5,718 & 0.004 & 0.30 & 0.002 & 0.025 & 34,603 & 197.9 & 114 & 651.9 \\
\hline & 1987 & 4,575 & 0.004 & 0.29 & 0.001 & 0.016 & 22,539 & 103.1 & 114 & 521.6 \\
\hline & 1988 & 3,095 & 0.004 & 0.29 & 0.001 & 0.016 & 22,539 & 69.8 & 114 & 352.8 \\
\hline & 1989 & 79 & 0.004 & 0.29 & 0.000 & 0.016 & 22,539 & 1.8 & 114 & 9.0 \\
\hline & 1990 & 67 & 0.004 & 0.29 & 0.000 & 0.016 & 22,539 & 1.5 & 114 & 7.6 \\
\hline \multicolumn{11}{|c|}{1991} \\
\hline & 1992 & 272 & 0.004 & 0.29 & 0.000 & 0.016 & 22,539 & 6.1 & 114 & 31.0 \\
\hline & 1993 & 114 & 0.004 & 0.29 & 0.000 & 0.016 & 22,539 & 2.6 & 114 & 13.0 \\
\hline & 1994 & 2,607 & 0.004 & 0.29 & 0.001 & 0.016 & 22,539 & 58.8 & 114 & 297.2 \\
\hline \multicolumn{11}{|c|}{ 1995-1999 } \\
\hline & & 125,161 & & & 0.0455 & & & $3,599.5$ & & $14,268.4$ \\
\hline
\end{tabular}


Table 5.1-3 ICPP Receipts and Constituent Quantities by Year

\begin{tabular}{|c|c|c|c|c|c|c|c|}
\hline \multirow[t]{2}{*}{ Period } & \multirow[t]{2}{*}{ Receipts (kg) } & \multicolumn{2}{|c|}{$\begin{array}{c}\mathrm{Pu} \\
(0.679 \mathrm{pCi} / \mathrm{g} U)\end{array}$} & \multicolumn{2}{|c|}{$\begin{array}{c}\mathrm{Np} \\
(1.82 \mathrm{pCi} / \mathrm{g} U)\end{array}$} & \multicolumn{2}{|c|}{$\begin{array}{c}\text { Tc } \\
(154 \text { pCi/g U) }\end{array}$} \\
\hline & & ppb & g & ppb & g & ppm & g \\
\hline 1953 & 102 & 0.05 & 0.000005 & 2550 & 0.26 & 9 & 0.92 \\
\hline 1954 & 231 & 0.05 & 0.000011 & 2550 & 0.59 & 9 & 2.08 \\
\hline 1955 & 828 & 0.05 & 0.000040 & 2550 & 2.11 & 9 & 7.45 \\
\hline 1956 & 744 & 0.05 & 0.000036 & 2550 & 1.90 & 9 & 6.70 \\
\hline 1957 & 797 & 0.05 & 0.000038 & 2550 & 2.03 & 9 & 7.17 \\
\hline 1958 & 898 & 0.05 & 0.000043 & 2550 & 2.29 & 9 & 8.08 \\
\hline 1959 & 3741 & 0.05 & 0.000180 & 2550 & 9.54 & 9 & 33.67 \\
\hline 1960 & 769 & 0.05 & 0.000037 & 2550 & 1.96 & 9 & 6.92 \\
\hline \multicolumn{8}{|l|}{1961} \\
\hline 1962 & 775 & 0.05 & 0.000037 & 2550 & 1.98 & 9 & 6.98 \\
\hline \multicolumn{8}{|l|}{1963} \\
\hline 1964 & 771 & 0.05 & 0.000037 & 2550 & 1.97 & 9 & 6.94 \\
\hline 1965 & 425 & 0.05 & 0.000020 & 2550 & 1.08 & 9 & 3.83 \\
\hline 1966 & 1408 & 0.05 & 0.000068 & 2550 & 3.59 & 9 & 12.67 \\
\hline \multicolumn{8}{|l|}{1967} \\
\hline 1968 & 394 & 0.05 & 0.000019 & 2550 & 1.00 & 9 & 3.55 \\
\hline 1969 & 427 & 0.05 & 0.000021 & 2550 & 1.09 & 9 & 3.84 \\
\hline 1970 & 108 & 0.05 & 0.000005 & 2550 & 0.28 & 9 & 0.97 \\
\hline 1971 & 1660 & 0.05 & 0.000080 & 2550 & 4.23 & 9 & 14.94 \\
\hline 1972 & 413 & 0.05 & 0.000020 & 2550 & 1.05 & 9 & 3.72 \\
\hline 1973 & 563 & 0.05 & 0.000027 & 2550 & 1.44 & 9 & 5.07 \\
\hline \multicolumn{8}{|l|}{1974} \\
\hline 1975 & 1702 & 0.05 & 0.000082 & 2550 & 4.34 & 9 & 15.32 \\
\hline 1976 & 195 & 0.05 & 0.000009 & 2550 & 0.50 & 9 & 1.76 \\
\hline 1977 & 1333 & 0.05 & 0.000064 & 2550 & 3.40 & 9 & 12.00 \\
\hline 1978 & 526 & 0.05 & 0.000025 & 2550 & 1.34 & 9 & 4.73 \\
\hline 1979 & 535 & 0.05 & 0.000026 & 2550 & 1.36 & 9 & 4.82 \\
\hline 1980 & -1 & 0.05 & 0.000000 & 2550 & 0.00 & 9 & -0.01 \\
\hline 1981 & 905 & 0.05 & 0.000044 & 2550 & 2.31 & 9 & 8.15 \\
\hline 1982 & 576 & 0.05 & 0.000028 & 2550 & 1.47 & 9 & 5.18 \\
\hline 1983 & 1041 & 0.05 & 0.000050 & 2550 & 2.65 & 9 & 9.37 \\
\hline 1984 & 2868 & 0.05 & 0.000138 & 2550 & 7.31 & 9 & 25.81 \\
\hline 1985 & 1 & 0.05 & 0.000000 & 2550 & 0.00 & 9 & 0.01 \\
\hline 1986 & 960 & 0.05 & 0.000046 & 2550 & 2.45 & 9 & 8.64 \\
\hline \multicolumn{8}{|c|}{ 1987-1988 } \\
\hline 1989 & 1 & 0.05 & 0.000000 & 2550 & 0.00 & 9 & 0.01 \\
\hline \multicolumn{8}{|c|}{$1990-1999$} \\
\hline & 25,696 & & 0.001239 & & 65.52 & & 231.28 \\
\hline
\end{tabular}

NOTE: Tables 5.1-2 and 5.1-3 report ppb values for Pu to two significant digits (X.XX), based upon the laboratory data available for this constituent. This raw data reported $\mathrm{Pu} \mu \mathrm{Ci} / \mathrm{g} U$ to three decimal places, and this degree of reporting was maintained through the conversion to ppb. It should not be interpreted as accurate at the ppb level to two decimal places, but recognized as a product of the calculation. 
As an example, the average $\mathrm{Pu}$ activity for the base period was $0.004 \mu \mathrm{Ci} / \mathrm{g} \mathrm{U}$. The representative Pu activity for each year (1964 through 1972) was calculated by multiplying 0.004 by $0.43 / 0.26$, to yield $0.007 \mu \mathrm{Ci} / \mathrm{g} \mathrm{U}$. This value was then assigned as the Pu activity for 1964 through 1972.

\section{5 through 1964}

No data (constituent levels or alpha ratios) were located for SRS materials prior to December 1964. To arrive at values for this timeframe, data were extrapolated from the nearest period of time for which data were available (although limited), which was the period of December 1964 through May 1972. The Pu and $\mathrm{Np}$ activities from this adjacent timeframe (roughly 8 years) were applied to each year 1955 through 1964.

Recall that the $\mathrm{Pu}$ and $\mathrm{Np}$ constituent levels for the 1964-1972 period of time were based upon reported alpha ratios for those years, adjusted by the fraction of the alpha ratio for $\mathrm{Pu}$ and $\mathrm{Np}$ from the base period (1977 through 1984). As a result, the values extrapolated for 1953 through 1964 present a lesser degree of certainty than other values reported here.

It is also important to recognize that, although this period represents over one third of the time that RU materials were being shipped/processed at the Y-12 Complex, the corresponding amount of material is only slightly over $10 \%$ of the total material sent to the plant from SRS. These were the first years of the RU program and the initial shipments were substantially smaller than those that would follow once the program became fully operational.

\section{Summary for Pu and Np Receipts}

Chapter 4 of the SRS Site Report for RU flow notes that for Pu and Np "analytical results for uranium shipments from the site were available for only a small portion of the uranium shipped from SRS over the years." The report further provides a "most likely" concentration for Pu of $0.251 \mathrm{ppb}$ and $73.4 \mathrm{ppb}$ for $\mathrm{Np}$.

The Np figure can be adjusted, based upon a uranium concentration in solution, to arrive at the ppb level for $\mathrm{Np}$ on a $\mathrm{U}$ basis. This concentration appears to be $6.82 \mathrm{gU} /$ liter (based upon a four-year average from other sources). Making this adjustment for $\mathrm{Np}$ at a concentration of $116.5 \mathrm{dpm} / \mathrm{ml}$ yields a revised figure of 11,021 ppb. An appendix in the SRS Report offers another value for $\mathrm{Np}$ concentration of $242 \mathrm{dpm} / \mathrm{ml}$. This figure results in Np levels of 25,739 ppb.

A comparison of the Y-12 Complex data shows good relative agreement with the SRS limited data for Pu. Np levels in the Y-12 Complex data, however, appear to be somewhat higher than those offered in the SRS report. Since the Y-12 Complex numbers are based upon a sizeable quantity of available data from the analytical laboratories over a period of several years, those values were used for this report.

Constituent quantities from the ICPP Site Report for $\mathrm{Pu}$ and $\mathrm{Np}^{4}$ are significantly lower than those determined from the Y-12 Complex data for SRS material. SRS concentrations for Np average 29,221 ppb, while ICPP reports 2,550 ppb for their material. Additionally, SRS reports an average $\mathrm{Pu}$ concentration of $0.38 \mathrm{ppb}$, compared to ICPP's value of $0.05 \mathrm{ppb}$. Table 5.1-4 provides a summary of the quantities received at the Y-12 Complex from each site.

${ }^{4}$ ICPP, Recycle Uranium Mass Balance Project, Idaho Site Report, INEEL/INT-99-01228. 
Table 5.1-4 Pu and Np Total Gram Quantities Received

\begin{tabular}{|l|l|c|} 
& Plutonium & Neptunium \\
\hline SRS & g & g \\
\hline ICPP & 0.05 & 3,600 \\
\hline TOTALS & 0.0012 & 66 \\
\hline
\end{tabular}

The reason for the differences in the respective constituent values for SRS versus ICPP is attributed to the different source of the material. ICPP reprocessed spent fuel from naval reactors and research reactors, while SRS reprocessed spent fuel from the production of plutonium. As a result, the spent fuel reprocessed at ICPP was "once through," i.e., not processed and subsequently recycled to the reactor. Accordingly, it would not have had the opportunity to accumulate the quantities of $\mathrm{Pu}, \mathrm{Np}$, and Tc that recycled material from multiple fuel cycles would have accumulated.

\subsubsection{Shipments}

Although data for shipments to SRS were not as readily available as that found for material receipts, a limited amount of information was located that addressed constituent levels in shipments for some of the time.

As with the RU receipts, a base period was established from which data was extrapolated to cover those years where data was otherwise not available. The base period for shipments was the time period of 1977 through 1984, with some additional data available for 1986 through 1989. Those years prior to 1977 (1953 through 1976) had no representative data that could be located. Also as with material receipts, the base period is discussed first.

\section{7 through 1984}

Data for this timeframe was predominantly in the form of laboratory reports and/or logbooktype records maintained by the operating group(s). The latter was often a chronological listing of the individual lab results that were routinely received and recorded as a normal part of the operation.

Data from the various sources was generally found to be in good agreement, and the West presentation provided comparable results. Data typically included the date, material code/description, ID numbers, constituent activities, alpha ratio, beta ratio, and total uranium alpha. Typically, several individual analyses or data sets were available for each year. The parameters of interest from this raw data were averaged to arrive at representative values for each year and subsequently applied to material shipments to determine total quantities of $\mathrm{Pu}$ and $\mathrm{Np}$.

\section{3 through 1976, 1985}

Representative data for this large period of time could not be located for purposes of this report. Consequently, the average values for the $\mathrm{Pu}(0.004 \mu \mathrm{Ci} / \mathrm{g} \mathrm{U})$ and $\mathrm{Np}(0.006 \mu \mathrm{Ci} / \mathrm{g} \mathrm{U})$ activities from the years 1977 through 1984 (the shipment base period) were applied to each of these years. 
While this extrapolation is more easily acceptable for years immediately adjacent to the base period, its application to materials shipped in years greatly separated from this period (i.e. the 1950s and early 1960s) has considerably less certainty. Nevertheless, no other data was located that represented these early years for materials shipped.

\section{6 through 1989}

Metal button data were located that are representative of the product for this period of time. The respective activities are $\mathrm{Pu} 0.002 \mu \mathrm{Ci} / \mathrm{g} \mathrm{U}$ and $\mathrm{Np} 0.003 \mu \mathrm{Ci} / \mathrm{g} \mathrm{U}$. Although the constituent activities differ somewhat from those reported for the base period, they were not used as a basis for calculating the quantities of these constituents.

\section{Summary for Pu and Np Shipments}

The SRS RU Site Report does not provide any quantitative constituent information for comparison to the limited data for shipments from the Y-12 Complex.

In determining the gram quantities of $\mathrm{Pu}$ and $\mathrm{Np}$ shipped from the plant, the respective activity levels in the shipped material are adjusted by the constituent specific activities to arrive at ppb. This number is then figured with gross material shipments to determine the total amounts, typically by year.

For reasons of classification, however, an annualized report of shipments to SRS cannot be provided in this document. Consequently, the base period activity levels are applied against the total quantity of material shipped $(120,384 \mathrm{~kg} \mathrm{U})$ to generate the total grams of each constituent. These figures are provided in Table 5.1-5.

Table 5.1-5 Pu and Np Total Grams Shipped

\begin{tabular}{|c|c|c|c|}
\hline \multicolumn{2}{|c|}{ Plutonium } & \multicolumn{2}{|c|}{ Neptunium } \\
\hline ppb & $\mathbf{g}$ & ppb & $\mathbf{g}$ \\
\hline 0.27 & 0.033 & 8,917 & 1,073 \\
\hline
\end{tabular}

\subsubsection{Technetium}

\subsubsection{Receipts}

No data were found that provided quantitative information on the actual constituent level for Tc. Technetium levels were indirectly monitored through the use of the beta ratio for purposes of employee exposure control, and although this ratio was often reported, Tc was not the only constituent present in RU that contributed to the measured activity. (The ratio was defined as the ratio of beta radiation of the RU sample to the beta radiation for unirradiated uranium.)

Beta ratios were reported in analytical data for years 1977 through 1984, with an average value for all of those years equal to 0.97. Attributing all of this activity to Tc, the formula for the beta ratio can be solved to yield a Tc constituent level of $114 \mathrm{ppm}$. This does not appear to be unreasonable since many of the beta sources in unirradiated uranium have a relatively short half life, leaving $\mathrm{Tc}$ and americium (from $\mathrm{Pu}^{241}$ decay) as the predominant beta sources. Attributing all the activity to Tc is a conservative approach. 
In the absence of Y-12 Complex qualitative data specific to Tc, the beta ratio is used as a basis for establishing Tc levels. This value is normally reported with the laboratory data for $\mathrm{Pu}$ and $\mathrm{Np}$ and provides a conservative basis for Tc levels.

The SRS Report cites 1983 as the only year for which an analysis of technetium in the uranium product stream was reported (DPST-84-385) and gives a typical concentration of 82 ppm. This figure is accompanied by a disclaimer that notes, "No claims are made as to the applicability of study results to other SRS production years." In light of the uncertainty of the SRS value, this mass balance report was completed using a Tc concentration based upon the beta ratios reported in Y-12 Complex analytical reports over a period of several years and extrapolated to years not represented in those reports.

The ICPP report provides Tc levels $(9 \mathrm{ppm})$ for the material that was sent to the Y-12 Complex from that facility. No Y-12 Complex data were located that were clearly identified as the ICPP material Tc levels, therefore the 9 ppm value was accepted for this material.

The technetium constituent quantities by year from Savannah River are included in Table 5.1-2, while Table 5.1-3 presents the quantities for Tc from the ICPP. Table 5.1-6 reports comparative ppm levels from SRS and ICPP, and the total grams received.

Table 5.1-6 Tc Total Grams Received

\begin{tabular}{|l|r|r|}
\hline & \multicolumn{2}{|c|}{ Technetium } \\
\hline SRS & ppm & \multicolumn{1}{c|}{$\mathbf{g}$} \\
\hline ICPP & 114 & 14,268 \\
\hline TOTAL & 9 & 231 \\
\hline
\end{tabular}

\subsubsection{Shipments}

The SRS Site Report did not offer any information relative to the Tc concentration in metal received from the Y-12 Complex. In addition, very limited data was available at the Y-12 Complex that provided Tc concentrations, except for the years 1977 through 1980 and 1981. The Uranium Radioactivities Reports for these years did provide beta ratios for the materials shipped as metal to SRS.

The average beta ratio for those years was 0.87 with a range of only 0.82 to 0.90 . If the same approach is taken for shipments that was discussed for receipts, i.e. attributing all beta activity to Tc, the average concentration is $102 \mathrm{ppm}$.

This approach was taken to report the Tc constituent levels that were shipped in the product to SRS and is reflected in Table 5.1-7. This provides a consistent methodology for receipts and shipments for this constituent and a more reasonable basis for comparison.

Table 5.1-7 Tc Total Grams Shipped

\begin{tabular}{|c|c|}
\hline \multicolumn{2}{|c|}{ Technetium } \\
\hline ppm & $\mathbf{g}$ \\
\hline 102 & 12,279 \\
\hline
\end{tabular}




\subsubsection{On-Site Inventory}

The inventory still on-site at the Y-12 Complex (13 MTU) is primarily composed of metalbutton product (9.7 MTU) and uranium-aluminum metal (U-Al) from SRS (3.3 MTU) that was not processed.

Button constituent quantities for $\mathrm{Pu}$ and $\mathrm{Np}$ were determined through the application of the Y-12 Complex data that reported activities of $0.002 \mu \mathrm{Ci} / \mathrm{g} \mathrm{U}(0.14 \mathrm{ppb})$ for $\mathrm{Pu}$ and $0.003 \mu \mathrm{Ci} / \mathrm{g}$ $\mathrm{U}$ (4783 ppb) for Np for metal product from years circa $1986-1989$.

A technetium level of $102 \mathrm{ppm}$ based upon a beta ratio wholly attributable to Tc (for materials shipped to SRS) yields the Tc concentration for this material.

The later year activity levels for incoming UN were applied to the U-Al material. These were based upon Y-12 Complex data for Pu and $\mathrm{Np}(0.004 \mu \mathrm{Ci} / \mathrm{g} \mathrm{U}$ and $0.016 \mu \mathrm{Ci} / \mathrm{g} \mathrm{U}$, respectively). The Tc concentration was derived from the average beta ratio (114 ppm) for receipts from that same general timeframe. The results of the application of this data to the onsite inventory are provided in Table 5.1-8.

Table 5.1-8 Constituents in On-Site Inventory

\begin{tabular}{|l|l|l|r|r|r|r|}
\hline & \multicolumn{2}{|c|}{ Pu } & \multicolumn{2}{c|}{ Np } & \multicolumn{2}{c|}{ Tc } \\
\hline U-Al $(3,300 \mathrm{~kg})$ & $0.29 \mathrm{ppb}$ & $0.001 \mathrm{~g}$ & $22,539 \mathrm{ppb}$ & $74.4 \mathrm{~g}$ & $114 \mathrm{ppm}$ & $376 \mathrm{~g}$ \\
\hline Buttons $(9,700 \mathrm{~kg})$ & $0.14 \mathrm{ppb}$ & $0.001 \mathrm{~g}$ & $4,783 \mathrm{ppb}$ & $46.4 \mathrm{~g}$ & $102 \mathrm{ppm}$ & $989 \mathrm{~g}$ \\
\hline TOTALS & & $\mathbf{0 . 0 0 2} \mathbf{g}$ & & $\mathbf{1 2 0 . 8} \mathbf{g}$ & & $\mathbf{1 , 3 6 5} \mathbf{g}$ \\
\hline
\end{tabular}

\subsubsection{Waste}

RU constituents were routinely discharged from the HEU processing complex in various effluent streams. As noted elsewhere in this report, the primary discharge point was the S-3 Ponds (until WETF became available in the mid-1980s). Other less significant discharge points include the Bear Creek Burial Grounds (for contaminated solid residues and process waste) and New Hope Pond (for surface contamination entrained by rainwater and secondary process wastewater).

The S-3 Pond sludge was extensively sampled and analyzed for metals and radioactive components prior to pond closure in the 1985-1986 timeframe. In a 1985 study of the exposure potential from S-3 Pond sludge, ${ }^{5}$ C.M. West reported the results of radiological analysis for the sludge from each pond after neutralization, biodenitrification, and removal of the aqueous phase. The report provides the activity for the constituents of concern per gram of sludge ( $\mathrm{pCi} / \mathrm{g}$ wet weight). The average depth of the sludge for each pond is also provided. If the volume of sludge is approximated for each pond, the total volume can be applied to the activities from this report to arrive at the actual gram quantity of each constituent. Table 5.1-9 shows the results of these calculations.

\footnotetext{
${ }^{5}$ Internal Correspondence, Exposure Potential From S-3 Pond Dried Sludge, C.M. West to H. D. Whitehead, Jr., June 3, 1985.
} 
Table 5.1-9 Constituent Quantities in S-3 Pond Sludge

\begin{tabular}{|c|c|c|c|c|c|}
\hline \multirow[t]{2}{*}{ Pond } & \multicolumn{5}{|c|}{ Activities (pCi) } \\
\hline & Volume $\left(\mathrm{ft}^{3}\right)$ & ${ }^{238} \mathrm{Pu}$ & ${ }^{239},{ }^{240} \mathrm{Pu}$ & Np & Tc \\
\hline SW & 52,000 & 4.37E10 & 4.21E9 & 1.15E10 & $1.51 \mathrm{E} 12$ \\
\hline NW & 84,000 & 3.93E10 & $<4.19$ E9 & $1.49 \mathrm{E} 10$ & 3.14E12 \\
\hline NE & 124,000 & $1.20 \mathrm{E} 10$ & 8.89E9 & 4.64E10 & 3.05E12 \\
\hline \multirow[t]{3}{*}{ SE } & 122,000 & 2.09E10 & $<6.08 E 9$ & 3.04E10 & $4.56 \mathrm{E} 13$ \\
\hline & Total Curies & 0.1159 & * & 0.1032 & 53.3 \\
\hline & Total Grams & 0.0068 & * & 145 & 3,136 \\
\hline
\end{tabular}

* The analysis of ${ }^{239,240} \mathrm{Pu}$ was not statistically valid.

If the SRS isotopic distribution for $\mathrm{Pu}$ is assumed (i.e., $84 \%{ }^{238} \mathrm{Pu}$, see Section 5.1.2), the total quantity of $\mathrm{Pu}$ in the pond sludge is estimated to be $0.008 \mathrm{~g}$. The total amount of Tc is estimated at 3,136 $\mathrm{g}$ and $\mathrm{Np}$ at $145 \mathrm{~g}$.

Residues and solids placed in the Bear Creek Burial Grounds were non-homogeneous and difficult to sample. Consequently, there are no RU exposure analyses or inventory numbers associated with the burial ground operation in the present analysis. However, since all solids leaving the HEU process area were extensively acid leached to recover residual uranium, potential impacts of RU constituents in Bear Creek are believed to be significantly less than in the S-3 Ponds. The Bear Creek waste management unit was also closed and capped in the same timeframe as the S-3 Ponds.

Contaminants collected in New Hope Pond were removed along with coal sediment from the Y-12 Complex coal storage yard on two different occasions (early 1970s and later 1980s) and placed in an unlined disposal basin on Chestnut Ridge above the water table. Fractional dose considerations associated with the routine operation and closure of New Hope Pond were judged to be less significant that similar activities around the S-3 Ponds. Like the S-3 Pond sludge, the New Hope Pond sediment was sampled and analyzed for radionuclides.

Disposal records and available analytical data for the West End Treatment Facility sludge storage tanks and New Hope Pond ${ }^{6.1 .6}$ were also reviewed. These records collectively indicated the presence of less than $0.01 \mathrm{~g} \mathrm{Pu}$, around $124 \mathrm{~g}$ of $\mathrm{Np}$, and approximately $59 \mathrm{~g} \mathrm{Tc}$. Table 5.1-10 presents the waste figures in summary.

Table 5.1-10 Constituent Quantities Present in Waste Streams

\begin{tabular}{|l|c|c|c|}
\hline Location & Pu $(\mathbf{g})$ & Np $(\mathbf{g})$ & Tc $(\mathbf{g})$ \\
\hline S-3 Ponds & 0.008 & 145 & 3,136 \\
\hline WETF & $<0.001$ & 100 & $\sim 50^{*}$ \\
\hline New Hope Pond & 0.004 & 24 & 9 \\
\hline TOTALS & $\sim \mathbf{0 . 0 1}$ & $\mathbf{2 6 9}$ & $\mathbf{3 , 2 0 0}$ \\
\hline
\end{tabular}

*The Tc quantity for WETF was estimated based upon known process flows.

\footnotetext{
${ }^{6}$ Saunders, M.B., Leachability of Samples from New Hope Pond Disposal Basin, Y/DZ-81, July $26,1983$.

${ }^{7}$ Internal Correspondence, “Transuranic Elements in Sediments from New Hope Pond and Sediment Basin,” G.G. Fee to H.D. Hickman, March 16, 1984.

${ }^{8}$ Internal Correspondence, "Modified Surface Contamination Limits for WETF Sludge Project, G.R. Galloway to R.W. Oliver et al., August 12, 1997.
} 


\subsubsection{Mass Balance}

The resulting mass balance for highly enriched RU and constituent flow through the Y-12 Complex is summarized in Table 5.1-11. This table compiles quantities of each constituent based upon the estimating logic presented in the preceding sections.

Table 5.1-11 Overall Mass Balance for Y-12 Complex Highly Enriched RU

\begin{tabular}{|l|c|c|c|c|c|}
\hline & Receipts & Shipments & Inventory & Waste & Difference \\
\hline $\mathrm{RU}(\mathrm{kg} \mathrm{U})$ & 150,857 & 120,384 & 13,082 & $\sim 100$ & $\sim 17,300$ \\
\hline $\mathrm{Pu}(\mathrm{g})$ & 0.051 & 0.033 & 0.002 & $\sim 0.01$ & $\sim 0$ \\
\hline $\mathrm{Np}(\mathrm{g})$ & 3,666 & 1,073 & 121 & 270 & $2,200(-300)^{*}$ \\
\hline Tc $(\mathrm{g})$ & 14,499 & 12,279 & 1,365 & 3,200 & $-2,345(335)^{\dagger}$ \\
\hline
\end{tabular}

* The Np difference is $-300 \mathrm{~g}$ if it is assumed that the reported $1.75 \mathrm{Ci}(2,500 \mathrm{~g}) \mathrm{Np}$ was buried in the Bear Creek Burial Grounds as solid waste or shipped off site to another DOE facility.

${ }^{\dagger}$ The Tc difference is $340 \mathrm{~g}$ if it is assumed that most Tc found in the southeast S-3 Pond came from ORGDP and is not included in receipts.

Chapter 3 provided mass balance information at the RU level, reporting approximately 17.3 MT highly enriched RU that is not specifically accounted for. As explained previously, this difference is primarily attributable to the inability to precisely distinguish between RU and nonRU shipments.

Based upon Y-12 Complex records of highly enriched RU receipts and shipments, material remaining in inventory, and determinations regarding quantities in disposal, there remain no more than trace quantities of $\mathrm{Pu}$ not accounted for.

In contrast, the overall mass balance based primarily-on receipt and shipment records cannot account for 2,200 $\mathrm{g}$ of $\mathrm{Np}$. In the historical plant record, reference is made to discharge of 2,500 g (1.75 Ci) of Np to the S-3 Ponds. As shown in Table 5.1-9, however, the amount of Np that can be accounted for by sampling and analysis of pond sludge is only $145 \mathrm{~g}$. A similar quantity was found in the WETF sludge. It is known by a few individuals in the plant that an ion exchange column was installed in the uranyl nitrate feed stream to specifically remove $\mathrm{Np}$ from the incoming SRS RU for use in another program. The spent or loaded ion exchange columns were removed from the feed line and sent off-site for Np recovery. Since there was little residual uranium contained on the ion exchange resin, this transaction was not listed as an RU transfer and was not placed in the plant uranium accountability record. Assuming that the 2,500 $\mathrm{g}$ of Np identified in the waste management record was indeed separated from the RU stream as suspected and either sent off-site for use elsewhere or buried as a solid waste in the Bear Creek Burial Grounds, the overall mass balance shows $300 \mathrm{~g}$ more $\mathrm{Np}$ than can be accounted for.

Additional historical information was received from Y-12 Complex operations regarding Np recovery operations just prior to the issuance of this report. The information included a 1962 summary description of the $\mathrm{Np}$ recovery process for shipments of dilute uranyl nitrate from $\mathrm{SRS}, 10$ communications of radiological protection safety measures, 11 and early years of analysis results for transuranics in SRS material. ${ }^{12}$ Time did not permit further analysis for this report.

\footnotetext{
${ }^{9}$ U.S. Department of Energy, Historical Radionuclide Releases from Current DOE Oak Ridge Operations Office Facilities, 1988.

${ }^{10}$ Internal Correspondence, “Np-237 Operations,” R.E. Trent to J.R. Barkman, April 5,1962.
} 
The overall Y-12 Complex mass balance shows 2,345 grams more Tc on the plant site than can be accounted for, based on the mass difference between the uranium feed, product, and waste streams. It should be noted that the normal flow of acid waste from the 9212 and $9206 \mathrm{HEU}$ operations to the S-3 Ponds went first into the NE basin. The flow was then routed by overflow pipe to the NW basin, then to the SW basin, and finally into the SE basin. Under this normal design flow pattern, one would expect to find the greatest concentration of Tc in the NE basin and the least in the SE basin. Sludge analysis, however, shows $179 \mathrm{~g}$ of Tc in the NE basin, $184 \mathrm{~g}$ in the NW, $89 \mathrm{~g}$ in the SW, and 2,680 $\mathrm{g}$ in the SE. The apparent discrepancy was explained by a former S-3 Pond manager, who stated that on several occasions Tc liquid waste was discharged directly to the SE basin from 5-gal waste drums received from ORGDP. These Tc residues were removed from the gaseous diffusion cascade from time to time during certain maintenance activities. If it is assumed that essentially all of the Tc in the SE basin came from ORGDP and was not included in the Y-12 Complex RU database, the mass balance difference is $335 \mathrm{~g} \mathrm{Tc}$, or $2 \%$ of the estimated total receipt.

\subsection{POTENTIAL AREAS OF CONCENTRATION}

A steady state process model was developed for the HEU-process flow sheet to help identify the likely RU constituent accumulation points in the various units that make up the Y-12 Complex HEU chemical operations and to provide order-of-magnitude estimates of stream compositions for fractional dose calculations using the prescribed DOE methodology. The output of the HEU-process model for the Savannah River case is given in Appendix B; stream numbers correspond to the process block diagram numbers given in Chapter 2. Accountability records and combined SRS and Y-12 Complex analytical data were used to establish the feed stream compositions as the basis for the particular calculations shown. The overall results and conclusions of this assessment are driven largely by the unusually high concentration of ${ }^{236} \mathrm{U}$ in the SRS RU.

The SRS case shows the greatest potential for exposure of the Y-12 Complex population, subjugating the fractional impact of the ICPP RU. This bulk difference between the SRS RU and ICPP RU is explained by the higher level of ${ }^{236} \mathrm{U}$ in the SRS feed stream $\left(27.8 \%{ }^{236} \mathrm{U}\right.$ average $)$ compared to ICPP $\left(<10 \%{ }^{236} \mathrm{U}\right)$ and the fact that most of the RU processed at the Y-12 Complex was received from SRS (125 MTU) versus ICPP (26 MTU).

Most of the highly enriched RU material processed at the Y-12 Complex was in the form of fairly pure uranyl nitrate (UN) solution or uranium oxide (chiefly $\mathrm{UO}_{2}, \mathrm{UO}_{3}$, and/or $\mathrm{U}_{3} \mathrm{O}_{8}$ ). Smaller amounts of RU alloy (e.g., U-Al), casting dross, floor sweepings, and various residues were also received. Relatively pure alloys and oxides were first converted to UN solution, mixed with incoming UN solution, and then fed directly to the secondary solvent extraction system for concentration and purification. Two solvent extraction systems were used to purify the HEU; the first employing dibutyl carbitol as the extractor, and the second, tributyl phosphate (TBP). Neither organic purification process was capable of discriminating ${ }^{236} \mathrm{U}$ from ${ }^{235} \mathrm{U}$ or ${ }^{238} \mathrm{U}$. Consequently, the uranium isotope distribution in the HEU feed was unaltered throughout the

\footnotetext{
${ }^{11}$ Internal Correspondence, "Safety Measures for Np-237 Processing," J.S. Reece to J.R. Barkman, September 9, 1960.

${ }^{12}$ Internal Correspondence, "Trans-Uranium Elements in SRO Material," R.H. Kent to J.R. Barkman, December 7, 1964.
} 
HEU chemical facility. It should be noted that the Y-12 Complex solvent extraction systems were designed and operated specifically to remove elemental weapons system contaminants, such as $\mathrm{C}, \mathrm{Fe}$, and $\mathrm{Cr}$, from $\mathrm{UN}$ with minimum loss of HEU to the acid waste raffinate stream. Further, the Y-12 Complex process was not modified specifically to remove TRU elements (i.e., $\mathrm{Pu}$ and $\mathrm{Np}$ ) or various RU fission products (e.g., Tc) from the feed HEU. As a result, the RU components were allowed to distribute among the various process streams without design or specific process controls.

Available analytical data show that the majority of the radionuclides of interest tended to follow the uranium through the aqueous process and, consequently, largely ended up in the HEU metal buttons. It is estimated from the model that from 60 to $80 \%$ of the TRU components fed to the chemical process ended up in the HEU metal. The behavior of Tc is less certain since less analytical data was recorded for this RU constituent. However, based on beta-ratio data of the solvent extraction raffinate streams, it can be inferred that the bulk (i.e., >90\%) of the Tc present in the process feed likely ended up in the HEU metal product.

The calculated results indicate that RU components moderately concentrated in the primary and secondary solvent extraction raffinate streams relative to the uranium flows. Analytical data taken from the S-3 Ponds and metal buttons are consistent with this model. The primary solvent extraction system raffinate was discharged to the S-3 Ponds during virtually all of the RU campaigns. The secondary system raffinate, on the other hand, was recycled to the primary system. Normally, one would expect the S-3 Ponds (stream 33, Appendix B) to be as concentrated in RU radioactivity as the primary raffinate. However, as shown in the process flow diagram in Appendix B, depleted uranium waste from other Y-12 Complex operations was also added to the S-3 Ponds (stream 31) and, later, to the WETF. The DU addition significantly diluted the TRU elements and fission products as well as the ${ }^{236} \mathrm{U}$ (since the DU contained little RU), making the S-3 Ponds and WETF less of a radiological hazard relative to unirradiated uranium.

\subsection{POTENTIAL FOR WORKER EXPOSURE}

Historically, worker protection from transuranics $\left({ }^{238} \mathrm{Pu},{ }^{239} \mathrm{Pu},{ }^{240} \mathrm{Pu}\right.$, and $\left.{ }^{237} \mathrm{~Np}\right)$ was provided by health physics programs for operators working with enriched, normal, or depleted uranium. This is due, in part, to the common method of detection (total alpha counting). Alpha particles emanating from uranium and transuranics are detectable in air and smear samples as well as urine samples collected routinely from uranium workers. As shown in Table 5.3-1, transuranics are significantly more active than even enriched uranium and therefore much more detectable.

A comprehensive health physics worker protection program, including radiation dosimetry, air sampling of the workplace, and routine urinalysis for identifying both uranium and total alpha level, was in place during the years that RU was processed at the Y-12 Complex. Health Physics Progress Reports were published on a semi-annual basis. Upon a limited review, it appears that the format and content of these reports remained relatively the same through the years. The progress report for the period January 1, 1953, to June 30, 1953, was selected for additional review because this reporting period coincides approximately with the time that RU was first 
processed at the Y-12 Complex and exemplifies the programs in place at that time. ${ }^{13}$ The following information is summarized and excerpted from that report:

Table 5.3-1 Comparison of Specific Activity of Uranium and Transuranics

\begin{tabular}{|c|c|}
\hline Material & $\begin{array}{c}\text { Specific Activity } \\
\text { (dpm per microgram) }\end{array}$ \\
\hline Normal Uranium & 1.5 \\
\hline${ }^{234} \mathrm{U}$ & 13,764 \\
\hline${ }^{235} \mathrm{U}$ & 5 \\
\hline${ }^{236} \mathrm{U}$ & 144 \\
\hline${ }^{237} \mathrm{~Np}$ & 1,550 \\
\hline${ }^{238} \mathrm{Pu}$ & $37,962,000$ \\
\hline${ }^{239} \mathrm{Pu}$ & 138,000 \\
\hline${ }^{240} \mathrm{Pu}$ & 501,720 \\
\hline
\end{tabular}

\section{Air Sampling}

Routine air sampling continued at all uranium, beryllium, and mercury handling operations. Special operations involving other contaminants were checked. Sampling for uranium included 10,940 general air samples and 1,266 operational/breathing-zone samples. Of these, $198(1.8 \%)$ of the general air samples and $451(35.6 \%)$ of the operational/breathing-zone samples were greater than the maximum permissible level (MPL) of $70 \mathrm{dpm}$ per cubic meter. Efforts to reduce airborne levels were in progress. The installation of new hoods and improved housekeeping in the foundry area had dropped concentrations from near the MPL in 1951 to less than $20 \%$ of the MPL by the second quarter of 1953.

\section{Routine Monitoring}

A total of 379 persons were regularly issued one or more film meters. The processed film included 7,436 regular issued badges, 5,932 regular issued rings, 975 visitor badges, and 420 neutron film badges.

\section{Routine Analysis}

During the period January 1 - June 30,1953 , a total of 8,750 uranium analyses were made: 5,274 by the electroplating method and 3,476 by the fluorometric method. Most results for workers processing normal uranium were less than $20 \mu \mathrm{g}$ per 24 hours. A small percentage (occurring only in weeks 2, 3, and 18) were between 20 and $30 \mu \mathrm{g}$ per 24 hours. Urinalysis results for "enhanced" urinalysis (workers processing enriched uranium) ranged as high as $90 \mu \mathrm{g}$ per 24 hours with approximately $10 \%$ of the results greater than $40 \mu \mathrm{g}$ per 24 hours.

\footnotetext{
${ }^{13}$ Carbide and Carbon Chemicals Co., Health Physics Progress Report, January 1, 1953 through June 30, 1953, Union Carbide and Carbon Company, Oak Ridge, TN.
} 
In addition, it was well known that transuranics as well as increased levels of ${ }^{236} \mathrm{U}$ were present in the RU received from SRS and ICPP. With this knowledge, specific analyses for transuranics were performed as appropriate, first by separation of the transuranics by chemical means and, after about 1960, by alpha spectroscopy techniques.

Beginning in 1961, about 2,200 employees per year were routinely monitored by bioassay and also in vivo techniques for internal exposure to uranium. In the period from 1961 to 1976, 49 employees were restricted from uranium work because they exceeded the established Plant Action Values (PAVs), a restriction rate of less than $0.05 \%$ per year of those being monitored. ${ }^{14}$

\section{Worker Protection by Virtue of Specification}

Prior to and during the processing of RU, the Y-12 Complex also operated as a uraniumprocessing facility. Careful consideration for worker protection was given to the introduction of RU for processing. A criterion for acceptance was based upon DOE/OR-859 ${ }^{15}$ which in turn, was derived from an informal agreement between the Y-12 Complex and SRS. The intent of this criterion was to maintain the relative hazard potentialof all non-uranium alpha emitters to less than $7 \%$ of the relative hazard potential of uranium. ${ }^{16}$ With this limitation, it was expected that RU could be safely managed by the measures already in place for processing uranium. The specification for RU included a limit for alpha activity in the form of the alpha ratio and also a limit on the level of gamma and beta activity. A detailed explanation of these specifications may be found in Section 4.3.

In the 1985 presentation to DOE compiled by Y-12 Complex Health Physicist, C.M. West, reactor returns (RU) were considered for the period of 1953 to 1984. Not only were incoming levels of transuranics allowed by specification investigated, but also any levels concentrated by processing at the Y-12 Complex.

A study to evaluate worker average exposure when working with RU was conducted at the Y-12 Complex from 1980 to 1984, comparing operators working with RU to workers in the same department not working with RU. The results are shown in Table 5.3-2.

This difference is considered the upper level of exposure due to the processing of reactor returns. The presentation included the conclusion that exposures at this level were not considered to be a significant health risk.

Average results from general air samples $(60,000)$ taken in areas where RU was processed from 1977 to 1985 were $3 \%$ of the uranium radioactivity concentration standard. The average alpha ratio for RU for these years was $30 \%$ of the specification. This specification was set to control exposure from plutonium to $7 \%$ of that from uranium. Using this data, the estimated internal dose (committed dose to bone) from transuranics was calculated to be 0.019 rem per year, considered to be an acceptable health risk.

\footnotetext{
${ }^{14}$ West, C.M., et al., Sixteen Years of Uranium Personnel Monitoring Experience in Retrospect, Union Carbide Company, July 1977.

${ }^{15}$ Egli et al., The Report of the Joint Task Force on Uranium Recycle Materials Processing, 1985.

${ }^{16}$ Vath and Duerksen, Criteria for Acceptance and Technical Assessment for Acceptance of Enriched Uranium at the Y-12 Plant, April 25, 1996.

${ }^{17}$ West, C.M., Radioactive Contaminants in Uranium Reactor Returns at the Oak Ridge Plant, 1985.
} 


\section{Table 5.3-2 Comparison of Exposures of Workers Handling Reactor Returns to Others in Same Department Not Handling Reactor Returns. Five-Year (1980 - 1984) Average Exposures in rem/year.}

\begin{tabular}{|l|c|c|c|}
\hline \multicolumn{1}{|c|}{ Group } & $\begin{array}{c}\text { Average No. of } \\
\text { Workers/Year }\end{array}$ & $\begin{array}{c}\text { Skin Exposure } \\
\text { (rem/year) }\end{array}$ & $\begin{array}{c}\text { Penetrating } \\
\text { Exposure } \\
\text { (rem/year) }\end{array}$ \\
\hline Working with reactor returns & 22 & 0.524 & 0.305 \\
\hline $\begin{array}{l}\text { Others in same department not working with } \\
\text { reactor returns }\end{array}$ & 180 & 0.176 & 0.112 \\
\hline DIFFERENCE & & 0.348 & 0.193 \\
\hline
\end{tabular}

\subsection{POTENTIAL FOR ENVIRONMENTAL CONTAMINATION}

As presented in Section 2.5, environmental monitoring has been performed on- and off-site at the Y-12 Complex since about 1953. As could be expected from the plant operating history, the most significant material releases have been uranium. Table 5.4-1 below presents a summary of radionuclide releases from the Y-12 Complex. 18

Table 5.4-1 Summary of Radionuclides Released to Air and Water or Buried at Y-12 Complex from 1944 through 1987

\begin{tabular}{|l|c|c|c|}
\hline \multicolumn{1}{|c|}{ Radionuclide } & Air (Curies) & Water (Curies) & Burial (Curies) \\
\hline Uranium & $13.87(6296 \mathrm{~kg})$ & $116.58(182,374 \mathrm{~kg})$ & $7,097(17,290,523 \mathrm{~kg})$ \\
\hline Thorium & - & 0.680 & 18.59 \\
\hline Technetium & & & $58.60^{\dagger}$
\end{tabular}

* Prior to 1972, liquid wastes that were transferred to the S-3 Ponds were recorded as burials.

${ }^{\dagger}$ Approximately 2,680 grams received from ORGDP was recorded as a burial.

The original table listed several radionuclides other than uranium, thorium, and technetium, including $\mathrm{Np}$ and $\mathrm{Pu}$. These radionuclides (along with the $\mathrm{Tc}$ ) were associated with recycled reactor product uranium solutions received from other DOE sites (primarily SRS and ICPP) since 1953. The recovery process for this solution resulted in some of these radionuclides remaining in the product (which was subsequently returned to SRS as metal buttons). The waste from the process went to the S-3 Ponds prior to about 1984 and was recorded as a burial. Since measurements at that time were made for contamination control purposes only, the exact quantities of these radionuclides that went to the ponds are unknown. Reporting thresholds were established for these radionuclides for accountability and security purposes. Releases of $\mathrm{Np}$ and $\mathrm{Pu}$ to the ponds were always below the reporting thresholds of $1.7 \mathrm{Ci}$ and $0.87 \mathrm{Ci}$, respectively.

A joint task force was assembled by DOE in 1985 to study past and then-current practices relating to the processing of uranium recycle materials. From the data reviewed, the task force did not disclose any instance in which the environment, safety, or health of plant workers or the

\footnotetext{
${ }^{18}$ U.S. Department of Energy, Historical Radionuclide Releases from Current Oak Ridge Operations Office Facilities, 1988.
} 
public were jeopardized or compromised. The primary recommendation was for the gaseous diffusion plants to develop formal specifications on maximum permissible levels of contaminants in enrichment feed materials. No recommendations were suggested regarding the releases from the Y-12 Complex.

The Task 7 component of the Oak Ridge Dose Reconstruction Project, initiated in 1994, involved performing qualitative and quantitative screening of various materials of concern at the DOE Oak Ridge sites. Materials screened included Np and Tc. Based on the analysis of the data, the Task 7 team determined that $\mathrm{Np}$ did not warrant further study. Although Tc was identified as one of the potential candidates for further study, it was not determined to be a highpriority candidate. 20

${ }^{19}$ Egli et al., Report of the Joint Task Force on Uranium Recycle Materials Processing, 1985.

${ }^{20}$ Bruce, Screening-Level Evaluation of Additional Potential Materials of Concern, July 1999. 


\subsection{RESULTS AND CONCLUSIONS}

\subsection{EXPLANATION OF RECYCLED URANIUM FLOW PATHS}

\subsubsection{Flow of RU into the Y-12 Complex}

RU entered the Y-12 Complex through a number of different pathways. The plant received RU from three primary source sites:

- receipts of $125,161 \mathrm{~kg}$ of highly enriched RU as UN solution or U-Al ingots from SRS; this material was processed in the plant's 9212 and/or 9206 facilities,

- receipts of $25,696 \mathrm{~kg}$ of highly enriched RU as UN solution or oxide from ICPP; this material was processed in the plant's 9212 and/or 9206 facilities, and

- receipts of $1,502 \mathrm{~kg}$ of slightly depleted RU as oxide from Hanford; the assay associated with this material indicates that it was DU (this material is believed to have been disposed of on the Oak Ridge Reservation without any processing in Y-12 Complex facilities).

The Y-12 Complex also received RU from the following secondary sites:

- receipts of $192,836 \mathrm{~kg}$ of slightly depleted RU from ORGDP; this material is believed to have been returned to ORGDP and

- receipts of 38,423 kg of RU as slightly depleted fluorination tower ash from PGDP; this material is believed to have been disposed of on the Oak Ridge Reservation or returned to PGDP without any processing in Y-12 Complex facilities.

The highly enriched RU received by the Y-12 Complex is estimated to have contained the following quantities of the RU constituents of concern:

- Pu: $0.051 \mathrm{~g}$

- Np: $3,700 \mathrm{~g}$

- Tc: $14,500 \mathrm{~g}$

\subsubsection{Flow of RU out of the Y-12 Complex}

RU streams exited the Y-12 Complex via:

- shipments totaling $120,384 \mathrm{~kg}$ of highly enriched RU as metal product to SRS,

- shipments totaling 29,614 kg of RU as slightly depleted fluorination tower ash to PGDP (this material was apparently ash that had been shipped from PGDP to the Y-12 Complex and stored at the plant, but not processed), and

- shipments totaling $192,836 \mathrm{~kg}$ of slightly depleted RU to ORGDP.

As of March 31, 1999, approximately 13 MT of highly enriched RU remained in the Y-12 Complex inventory. 
The estimated mass balance for highly enriched RU, which is of most concern for worker exposure and is the primary focus of this project, is summarized in Table 6.1-1. A discrepancy in the mass balance between receipts and shipments (plus inventory and waste) reflects an inability to precisely distinguish between RU and non-RU shipments and receipts involving the Y-12 Complex and Savannah River. Shipments of fresh fuel (non-RU) and sweetener (also non-RU) were made from the Y-12 Complex to SRS along with RU shipments. The only way to distinguish between these RU and non-RU streams using available records is by enrichment level. Shipments of $\leq 90 \%$ enrichment were assumed to be RU. Shipments of $>90 \%$ enrichment were assumed to be non-RU fresh fuel or sweetener. This methodology using enrichment level to distinguish between RU and non-RU results in good estimates of RU flows that are reasonably consistent with SRS estimates. Although this is the best available means of distinguishing RU streams, this method does leave a difference of approximately 17.3 MTU between receipts and shipments.

Table 6.1-1 Estimated Mass Balance for Highly Enriched RU

\begin{tabular}{|c|c|c|}
\hline & $\begin{array}{l}\text { RU Received } \\
\text { (kg U) }\end{array}$ & $\begin{array}{c}\text { RU Shipped } \\
\text { (kg U) }\end{array}$ \\
\hline Savannah River & 125,161 & 120,384 \\
\hline ICPP & 25,696 & 0 \\
\hline TOTAL & 150,857 & 120,384 \\
\hline Total RU Shipped & & 120,384 \\
\hline RU Inventory (as of 3/31/99) & & 13,082 \\
\hline Estimated RU Waste & & $\sim 100$ \\
\hline TOTAL & 150,857 & 133,566 \\
\hline Difference* $^{*}$ & & $\sim 17,300$ \\
\hline
\end{tabular}

Slightly depleted RU streams received by the Y-12 Complex from ORGDP, PGDP, and Hanford are believed to have been returned to the shipping site or disposed of as waste on the Oak Ridge Reservation. No evidence of Y-12 Complex processing of this material was identified in the historical records reviewed by the Project Team.

\subsubsection{Flow of RU within the Y-12 Complex}

Within the Y-12 Complex, highly enriched RU followed pathways associated with:

- Building 9212 complex processes,

- Building 9206 processes, and

- processes associated with other Y-12 Complex facilities.

The steps associated with each of these pathways are described in the following sections.

\footnotetext{
${ }^{1}$ Five shipments of slightly enriched RU oxide from SRS totaling about 42.6 MT were received at the Y-12 Complex but immediately transferred to Fernald.
} 


\subsubsection{Building 9212 Complex Processes}

Building 9212 complex processes involved the following pathways:

- $\quad$ receiving UN solution from ICPP (in safe bottles) or from SRS (in tanker trucks)

- weighing SRS tanker trucks (at Building 9929-1)

- $\quad$ sampling UN solution

- pouring UN solution from ICPP safe bottles into "pour-up" stations for transfer to intermediate storage tanks

- $\quad$ pumping UN solution from SRS tanker trucks to 9212

- evaporating and concentrating UN

- manual filling and loading of UN into safe bottles for transfer to 9206 (in the period after 9206 assumed responsibility for certain recovery operations from 9212)

- $\mathrm{ICPP} \mathrm{UO}_{3}$ received and dissolved to produce UN (in the period after ICPP began sending $\mathrm{UO}_{3}$ instead of $\mathrm{UN}$ )

- $\quad$ purification of UN via solvent extraction (primary and secondary extraction)

- $\quad$ pumping of solvent extraction raffinate to S-3 Ponds

- feeding of solvent extraction raffinate to 9212 bioreactor

- transporting of solvent extraction raffinate to WETF

- denitration of $\mathrm{UNH}$ to $\mathrm{UO}_{3}$

- maintenance on denitrator or fluid beds

- conversion of $\mathrm{UO}_{3}$ to $\mathrm{UF}_{4}$ in converted lab muffle furnaces

- removal of dry $\mathrm{UF}_{4}$ from process

- "bomb" reduction of $\mathrm{UF}_{4}$ to uranium metal

- $\quad$ sampling, fracturing, and packaging of uranium metal buttons

- $\quad$ salvage operations for U-Al from SRS

- metal product shipped from Building 9720-5

\subsubsection{Building 9206 Processes}

Building 9206 processes involved the following pathways:

- UN solution "poured-up" into safe tanks

- U-Al ingots received from SRS at Building 9720-5

- dross and sweepings received

- U-Al ingots (or dross/sweepings) dissolved in $\mathrm{NaOH}$ to remove $\mathrm{Al}$; sodium diuranate produced

- $\quad$ sodium diuranate dissolved in nitric acid to produce UN

- $\mathrm{UO}_{3}$ received and dissolved to form $\mathrm{UN}$

- $\quad$ purification of UN via solvent extraction (primary and secondary extraction)

- $\quad$ isolation and transport of raffinate to 9212

- denitration of $\mathrm{UNH}$ to $\mathrm{UO}_{3}$

- maintenance on denitrator or fluid beds

- conversion of $\mathrm{UO}_{3}$ to $\mathrm{UF}_{4}$ 
- removal of dry $\mathrm{UF}_{4}$ from process

- "bomb" reduction of $\mathrm{UF}_{4}$ to uranium metal

\subsubsection{Processes Associated with Other Y-12 Complex Facilities}

- $\quad$ capping and closure of S-3 Ponds and sludge removal and closure of New Hope Pond

- treatment of nitrate waste at WETF

- $\quad$ storage of RU materials at Building 9720-5

\subsection{EVALUATION OF ACTIVITIES THAT INVOLVED POTENTIAL WORKER EXPOSURE TO RU CONSTITUENTS}

Prior to and during the processing of RU, the Y-12 Complex also operated as a uraniumprocessing facility. Careful consideration for worker protection was given to the introduction of RU for processing. A criterion for acceptance was based upon DOE/OR-85924 which in turn, was derived from an informal agreement between the Y-12 Complex and SRS. The intent of this criterion was to maintain the relative hazard potential of all non-uranium alpha emitters to less than $7 \%$ of the relative hazard potential of uranium. With this limitation, it was expected that RU could be safely managed by the measures already in place for processing uranium.

The Project Team carefully analyzed and evaluated 36 activities identified as involving potential for worker exposure. The team assigned the following Occupational Exposure Potential (OEP) scores:
- $\quad$ No Significant OEP
8 activities
- Low OEP
1 activity
- Moderate OEP
27 activities

Available analytical data showed that the majority of the RU constituents of concern tended to follow the HEU through the chemical processes in Buildings 9212 and 9206. Consequently, a majority of the RU constituents ended up in the HEU metal buttons shipped to SRS, while some concentration of RU constituents (relative to the uranium flow) occurred in the various solvent extraction raffinate streams. However, dose calculations using the prescribed DOE methodology indicate that the fractional contribution of the RU constituents for most process streams generally was greater than 50\%. Consequently, for most exposure scenarios identified in Table 2.6, a value of 3 was assigned for the constituent level. The reader should note that the TRU-element and fission-product concentrations alone were not sufficiently high for any of the exposure scenarios to warrant this highest constituent rating of 3 . Instead, the assignment of a constituent level of 3 was driven largely by the unusually high concentrations of ${ }^{236} \mathrm{U}$ in the SRS RU. On the other hand, ICPP RU had an average ${ }^{236} \mathrm{U}$ content of $<10 \%$. Activities involving only ICPP RU thus received a constituent level rating of 2 .

\footnotetext{
${ }^{2}$ Egli et al., The Report of the Joint Task Force on Uranium Recycle Materials Processing, 1985.

${ }^{3}$ Vath and Duerksen, Criteria for Acceptance and Technical Assessment for Acceptance of Enriched Uranium at the Y-12 Plant, April 25, 1996.
} 
Airborne potential values associated with the various exposure scenarios ranged from 0 to 3. The lowest airborne rating was assigned to HEU operations in which there was virtually no potential for direct worker contact with RU. A value of 1 was assigned to HEU operations involving direct exposure to metal or consolidated solids. A value of 2 was assigned for activities involving exposure to liquid solutions that might spray or evaporate to dryness outside the equipment. A value of 3 was assigned to operations involving direct contact with finely divided RU solids. Duration exposure values were based on actual contact time with RU as defined by DOE.

Most of the potential exposure activities at the Y-12 Complex were found to have a "Moderate" OEP rating as a result of the combined product of a constituent level value of 3 with a value of 1 or 2 for airborne potential and exposure duration. Certain maintenance activities involving equipment that contained finely divided RU solids were assigned a value of 3 for airborne potential. However, because these types of maintenance activities were not performed very often, the overall OEP was rated "Moderate," with a cumulative score of 9.

In no instance did any identified activity involve a combination of airborne potential, constituent level, and exposure duration that produced an OEP score in the "High" range.

\subsection{IDENTIFICATION AND EVALUATION OF PROCESSES OR FACILITIES THAT INVOLVED POTENTIAL ENVIRONMENTAL RELEASES}

Solvent raffinate streams from Buildings 9212 and 9206 extraction systems-as well as condensed acid streams from the various UN solution evaporators and denitrators-were ultimately discharged to the unlined S-3 Ponds. Chemical analysis of the S-3 Pond sludge indicated the presence of 3,140 $\mathrm{g}$ of Tc, $145 \mathrm{~g}$ of $\mathrm{Np}$, and $<0.01 \mathrm{~g}$ of Pu. The S-3 Ponds were capped in 1986, with the sludge left in place under EPA oversight. Uranium has been detected in groundwater monitoring wells around the S-3 Ponds. Therefore, one can infer that RU constituents also leached to the nearby environment from the S-3 Ponds. Data from other locations, such as the WETF and New Hope Pond, were analyzed and determined to have no significant potential for environmental releases.

\subsection{DISCUSSION OF DATA SOURCES}

To identify and retrieve data, the Project Team searched the Y-12 Complex Records Center and a variety of other data collections at theY-12 Complex, including electronic systems and administrative files. Major data sources consulted and analyzed included:

- $\quad$ NMC\&A data, including shipping, receiving, and inventory records (e.g., individual form 101 and 741 Nuclear Material Transfer Reports),

- Y-12 Complex historical site reports on shipments and receipts,

- Y-12 Complex reports describing facilities and production processes,

- Y-12 Complex health physics records,

- Y-12 Complex production records,

- Y-12 Complex analytical laboratory records,

- Y-12 Complex internal correspondence reports,

- correspondence between shippers and receivers, 
- historical DOE and contractor reports,

- more recent (i.e., post-1995) health physics reports on the site,

- more recent (i.e., post-1995) environmental survey reports on the site, and

- interviews with Y-12 Complex personnel with direct experience in RU operations.

For incoming and outgoing shipments that lacked sufficient analytical data to ascertain RU constituent flows, the Project Team developed estimates for quantities of RU and/or constituents. These estimates were based on extrapolations from actual data and represent (1) application of known data from similar material and/or circumstances or (2) application of known data from a specific time period over a longer or a shorter period of time. All such estimates and their bases are specifically identified in this report.

This report has been developed to identify and address the significant sources and quantities of RU at the Y-12 Complex from the standpoint of potential worker exposure or environmental consequences. The RU identified as having been received, processed, or shipped by the Y-12 Complex reflects the classical definition of RU as uranium that has been irradiated in reactors and subsequently processed to recover uranium for recycle. Other DOE sites have labeled all material shipped or received during certain periods or from certain facilities as RU. As a result, there exist some discrepancies among sites regarding quantities of RU shipments and receipts that may need to be resolved.

\subsection{CONCLUSIONS}

\subsubsection{Potential Personnel Exposure}

Although the Project Team identified 36 activities as having potential for worker exposure, in no instance did any identified activity produce an OEP score in the "High" range. As a result, the potential for worker exposure to TRU elements and fission products at the $\mathrm{Y}-12$ Complex is considered low to moderate.

Early in its existence, the Y-12 Complex implemented a worker protection program that included worker radiological protection (see Section 2.7). This program incorporated such elements as personnel protective equipment, personnel monitoring, environmental monitoring, work location surveys, work-time limits on jobs with penetrating radiation, excretion rate limits, periodic examinations of personnel, and Plant Action Level limits. The inhalation of radioactive materials was recognized as the most important source of possible exposure at the Y-12 Complex. Consequently, administrative controls were primarily designed to guard against associated hazards.

Worker protection measures in place at the Y-12 Complex likely provided substantial mitigation to the risks introduced by the activities rated as moderate to low in OEP. However, dose assessment studies may be warranted as a follow-on activity to provide a more detailed assessment of worker exposure.

\subsubsection{Potential Environmental Release}

Soil and groundwater around the Y-12 Complex are contaminated with various radionuclides as a direct result of the nature of the Y-12 Complex work and past disposal practices. However, the quantities of RU constituents in and around the plant are very small 
and pose no threat to the immediate environment or the surrounding communities. A clear understanding of the nature and extent of the contamination exists, and ongoing environmental programs continue to verify this conclusion. The report of the joint task force assembled by DOE in 1985 to study past and (then) current practices related to the processing of RU reflected similar conclusions. 4 The task force did not find any instance at the Y-12 Complex in which the environment was jeopardized or compromised.

An Oak Ridge Dose Reconstruction Project was initiated in 1994 as follow-up to the Oak Ridge Dose Reconstruction Feasibility Study, which recommended a closer examination of past uranium emissions and potential resulting exposures (see Section 2.8). The Task 6 component of the project involved further evaluation of Oak Ridge uranium operations and effluent monitoring records to determine if uranium releases from the ORR likely resulted in off-site doses that warranted further study. The results were documented in the July 1999 Task 6 report. ${ }^{6}$ The Task 6 team concluded that earlier estimates of uranium releases had been underestimated. However, based on the decision guidelines from ORHASP, the Task 6 team concluded that while Y-12 Complex uranium releases are candidates for further study, they are not high-priority candidates.

The Task 7 component of the project involved performing qualitative and quantitative screening of various materials of concern at the Y-12 Complex and the other DOE Oak Ridge sites. Materials screened included Np and Tc. Results were reported in the Task 7 report. ${ }^{6}$ Based on the analysis of data, the Task 7 team determined that Np did not warrant further study. Although Tc was identified as one of the potential candidates for further study, it was not determined to be a high-priority candidate.

These analyses, along with other information on environmental consequences from Y-12 Complex operations, identify candidate environmental issues for additional study. However, candidate issues related to the processing of RU have not been determined to be high-priority candidates for further study.

\footnotetext{
${ }^{4}$ Egli et al., Report of the Joint Task Force on Uranium Recycle Materials Processing, 1985.

${ }^{5}$ Buddenbaum, John E., et al. Uranium Releases from the Oak Ridge Reservation-A Review of the Quality of Historical Effluent Monitoring Data and a Screening Evaluation of Potential Off-Site Exposures, 1999.

${ }^{6}$ Bruce, Gretchen M. Screening-Level Evaluation of Additional Potential Materials of Concern, 1999.
} 
This page intentionally left blank.

6-8 


\subsection{REFERENCES}

Barg, Don C. TRU and DU at SMC, Report on Mass Balance at SMC. June 19, 2000.

Bruce, Gretchen M. Screening-Level Evaluation of Additional Potential Materials of Concern. Reports of the Oak Ridge Dose Reconstruction, Vol.5, The Report of Project Task 7, ChemRisk, Alameda, Cal., July 1999.

Buddenbaum, John E., et al. Uranium Releases from the Oak Ridge Reservation- A Review of the Quality of Historical Effluent Monitoring Data and a Screening Evaluation of Potential Off-Site Exposures. Reports of the Oak Ridge Dose Reconstruction, Vol.5, The Report of Project Task 6, ChemRisk, Alameda, Cal., July 1999.

Carbide and Carbon Chemicals Company. Health Physics Progress Report. Y-1070 and Y-1074, Y-12 Plant, 1953.

Cook et al. Phase I Data Summary Report for the Clinch River Remedial Investigation: Health Risk and Ecological Risk Screening Assessment. Environmental Sciences Division, Report ORNL/ER-155, December 1992

Croff, A.G. ORIGEN2 - A Revised and Updated Version of the Oak Ridge Isotope Generation and Depletion Code. ORNL-5621, 1980.

Egli, D., et al. The Report of the Joint Task Force on Uranium Recycle Materials Processing. DOE/OR-859, U.S. Department of Energy, Oak Ridge Operations, 1985.

Hoffman, F.O. Environmental Behavior of Technetium in Soil and Vegetation: Implications for Radiological Impact Assessment. ORNL-5856, 1982.

ICPP. Recycled Uranium Mass Balance Project, Idaho Site Report. INEEL/INT-9901228.

Lockheed Martin Energy Systems, Inc. Grouping Uranium Metal Buttons for the OffSpecification Fuel Project. HEU Disposition Program Office, HDPO/99-14, September 17, 1999.

Lockheed Martin Energy Systems, Inc. Transuranic Hazard Assessment at the Y-12 Plant. Radiological Control Organization, RCO/TR-001, July 29, 1997.

Martin Marietta Energy Systems. Sampling Enriched Uranium for Fission Product and Transuranic Impurities. Oak Ridge Y-12 Plant Procedures, Metal Preparation Division, Enriched Uranium Operations Department, 50-37-EU-004, October 17, 1988.

Oak Ridge Gaseous Diffusion Plant. Draft Mass Balance, ORGDP. From Box 8-3-5, K25 Site Records Center, 1978. 
Oak Ridge Gaseous Diffusion Plant. Environmental Radioactivity Levels, the Oak Ridge Gaseous Diffusion Plant. News Releases, January 1959 through June 1964.

Oak Ridge Health Agreement Steering Panel. Releases of Contaminants from Oak Ridge Facilities and Risks to Public Health. Final Report, ORO03091, December 1999.

Owings, E. Historical Review of Accountable Nuclear Materials at the Y-12 Plant (U). Y-DG-256549, Rev. 2, July 28, 1995.

Savannah River Site. Historical Generation and Flow of Recycled Uranium at the Savannah River Site. ESH-PEQ-2000-00059.

Tennessee Valley Authority. Instream Contaminant Study, Task 1: Water Sampling and Analysis. Office of Natural Resources and Economic Development, Knoxville, Tennessee, April 1985.

Union Carbide Corporation. The Chemical and Radiological Characterization of the S-3 Ponds. Y/MA-6400, July 14, 1983.

Union Carbide Nuclear Company. Y-12 Plant Quarterly Health Physics Report, Second Quarter CY 1964. Y-KB-52, Nuclear Division, Y-12 Plant, September 8, 1964.

Union Carbide Nuclear Company. Y-12 Radiation Safety Manual. Y-1401, Nuclear Division, Y-12 Plant, July 23, 1963.

Union Carbide Nuclear Company. The Y-12 Health Physics Program. Y-1186, Y-12 Plant, November 1, 1957.

U.S. Department of Energy. Preliminary Draft Site-Wide Environmental Impact Statement for the Oak Ridge Y-12 Plant, Volume 1. DOE/EIS-0309, April 2000.

U.S. Department of Energy. Historical Generation and Flow of Recycled Uranium in the DOE Complex: Project Plan. February 2000.

U.S. Department of Energy. Historical Radionuclide Releases from Current DOE Oak Ridge Operations Office Facilities. ORO-890, 1988.

Vath, J.E., and W.K. Duerksen. Criteria for Acceptance and Technical Assessment for Acceptance of Enriched Uranium at the Y-12 Plant. Y/LB-15,920, April 25, 1996. 


\section{APPENDIX A}

\section{DE MINIMUS CALCULATION}

In accordance with methodology prescribed by Appendix A of the DOE Mass Balance Project Plan,, calculations were performed to estimate for each of the various process streams the additional dose presented by constituents in irradiated uranium over that of the uranium itself. The DOE EH-3 team provided a standardized tool, in the form of an electronic spreadsheet prepared specifically for the purpose, to perform the dose fraction calculations. The calculation and its technical basis are described in detail in the Project Plan, and an example of the output from the tool is shown in Figure A-1. To use the tool, the following information about the process stream being considered must be determined and entered into the spreadsheet:

- chemical form (e.g., $\left.\mathrm{UF}_{6}\right)$

Figure A-1 Example Output of RU

- level of enrichment in the ${ }^{235} \mathrm{U}$ isotope

- mass fraction of the constituents ${ }^{238} \mathrm{Pu},{ }^{239} \mathrm{Pu},{ }^{240} \mathrm{Pu},{ }^{237} \mathrm{~Np},{ }^{241} \mathrm{Am}$, ${ }^{236} \mathrm{U}$, and ${ }^{99} \mathrm{Tc}$

The required information was determined by assuming estimates based on available analytical data, process knowledge, and engineering judgment. Calculations were performed for the streams of interest as identified in the flow diagrams in Appendix B. Assumptions for and results of the stream calculations are summarized in Appendix B.

A result of $<0.1$ indicates that the additional dose presented by the RU constituents is less than $10 \%$ of that of the uranium itself. RU streams characterized by a dose fraction of $<0.1$ were deemed de minimis in accordance with the definition established for the Recycled Uranium Mass Balance Project. For those Dose Fraction Calculator

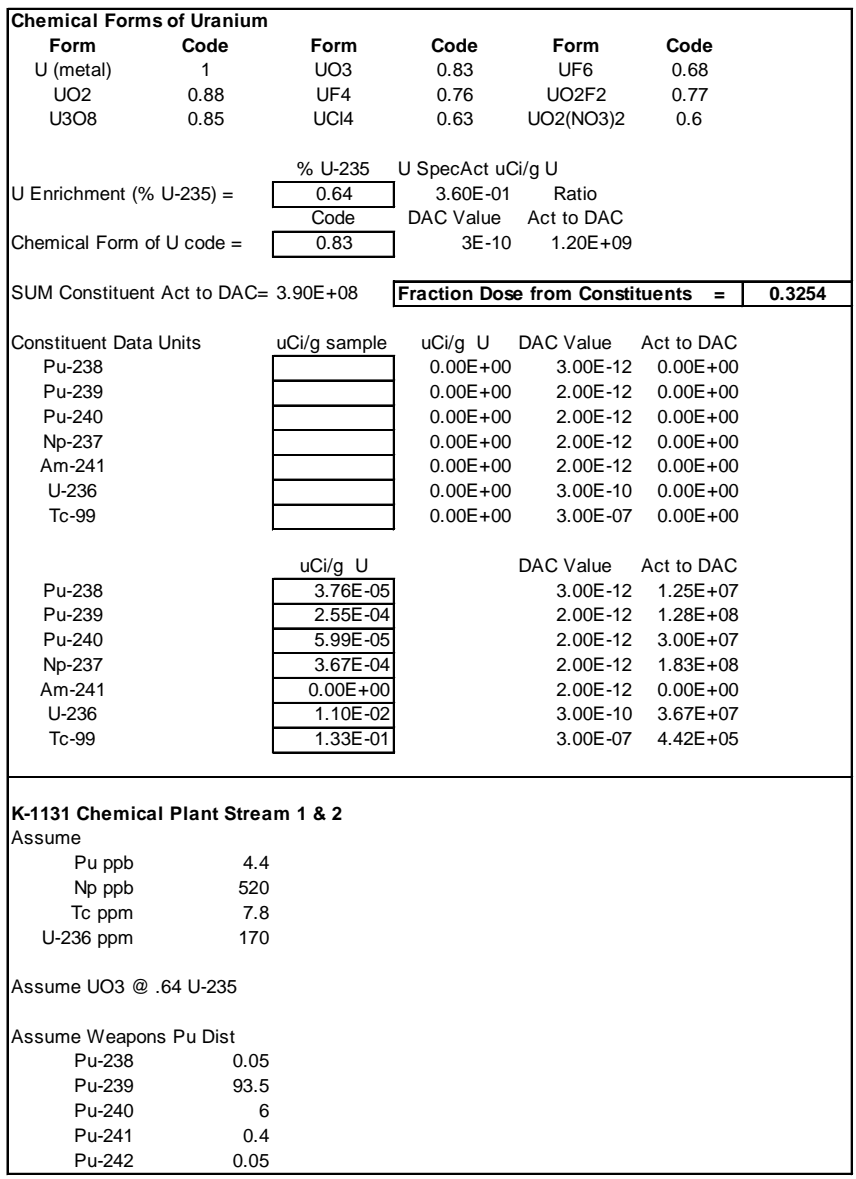
streams, the radiation-protection measures in place for the presence of uranium are considered adequate for worker protection.

\footnotetext{
${ }^{1}$ U.S. DOE, Historical Generation and Flow of Recycled Uranium in the DOE Complex, February 2000.
} 
This page intentionally left blank.

A-2 


\section{APPENDIX B \\ OCCUPATIONAL EXPOSURE POTENTIAL METHODOLOGY}

The Occupational Exposure Potential (OEP), shown in Table 2.6, is a score derived from the product of three parameters qualitatively assigned by the Project Team. The parameters are airborne potential, constituent level, and exposure duration. Each parameter is assigned a numeric value according to prescribed criteria.

\section{Airborne Potential}

This parameter is a subjective assignment of the likelihood of the contaminant to become airborne or concentrated in air. The judgment is largely based upon the form of the material and the nature of the particular operation. An associated numeric value is based on the following criteria:

$\begin{array}{cl}\text { Value } & \text { Likelihood } \\ 0 & \text { No likelihood of being airborne } \\ 1 & \text { Low airborne potential } \\ 2 & \text { Moderate airborne potential } \\ 3 & \text { High airborne potential }\end{array}$

\section{Constituent Level}

Calculations for each of the various product streams were performed to estimate the additional dose presented by constituents present in irradiated uranium over that of the uranium alone. The DOE EH-3 team provided a standardized tool, in the form of an electronic spreadsheet, to perform the dose fraction calculations. The calculation and its technical basis are described in detail in the Historical Generation and Flow of Recycled Uranium in the DOE Complex Project Plan. To use the tool, the following information about the process stream being considered was determined and entered in the spreadsheet:

- chemical form

- level of enrichment in the ${ }^{235} \mathrm{U}$ isotope

- mass fraction of the constituents ${ }^{238} \mathrm{Pu},{ }^{239} \mathrm{Pu},{ }^{240} \mathrm{Pu},{ }^{237} \mathrm{~Np},{ }^{241} \mathrm{Am},{ }^{236} \mathrm{U}$, and ${ }^{99} \mathrm{Tc}$

The required information was determined by assuming estimates based on available analytical data, process knowledge, and engineering judgment, and calculations were performed for the streams of interest. Assumptions for the calculations and the results are summarized in the accompanying tables.

The calculated fractional dose was then compared against criteria for assignment of a respective numeric value: 


\section{Value Likelihood}

$0 \quad$ Sum of constituents clearly below de minimis levels (clearly less than $10 \%$ additional dose)

1 Sum of constituents likely to cause up to $20 \%$ total dose

2 Sum of constituents likely to cause more than $20 \%$ but less than $50 \%$ total dose

3 Sum of constituents likely to cause $50 \%$ or more of total dose

\section{Exposure Duration}

This parameter considers the time of worker exposure on the job. As such, it considers whether or not a particular activity was conducted infrequently or was carried out on a daily basis. Exposure duration was also based upon a set of criteria to arrive at a numeric value:

\section{Value Likelihood}

150 hours per year or less

$2 \quad$ More than 50 hours per year but less than 500 hours per year

3500 or more hours per year

\section{OEP Ratings}

Multiplying the three values for airborne potential, constituent level, and exposure duration produces an overall value that falls within a range that determines the OEP score:

$\begin{array}{cc}\text { Score } & \text { Product Range } \\ 0 & 0 \\ 1 & 1 \\ 2 & 2-9 \\ 3 & >10\end{array}$

\section{Likelihood}

"No significant" occupational exposure potential "Low" occupational exposure potential "Moderate" occupational exposure potential "High" occupational exposure potential

The results of this rating system for Y-12 Complex activities are presented in the following charts and tables, which were used to provide the OEP ratings presented in Table 2.6. 
RU Occupational Exposure Potential at the Y-12 Complex

\begin{tabular}{|c|c|c|c|c|c|c|c|c|}
\hline \multirow{2}{*}{ Y-12 HEU Activity } & \multicolumn{4}{|c|}{$\begin{array}{c}\text { Stream } \\
\text { Composition, U Basis }\end{array}$} & \multicolumn{4}{|c|}{$\begin{array}{l}\text { Exposure } \\
\text { Potential }\end{array}$} \\
\hline & $\begin{array}{l}\mathrm{Pu} \\
\mathrm{ppb}\end{array}$ & $\begin{array}{c}\mathrm{Np} \\
\mathrm{ppm}\end{array}$ & $\begin{array}{c}\text { Tc } \\
\mathrm{ppm}\end{array}$ & $\begin{array}{l}{ }^{236} \mathrm{U} \\
\%\end{array}$ & $\begin{array}{c}\text { Constit. } \\
\text { Level }\end{array}$ & $\begin{array}{l}\text { Airborne } \\
\text { Potential }\end{array}$ & $\begin{array}{l}\text { Exposure } \\
\text { Duration }\end{array}$ & $\begin{array}{c}\text { Occ. } \\
\text { Exposure }\end{array}$ \\
\hline $\begin{array}{l}\text { Activities with Bldg } 9212 \\
\text { 1A. ICPP UN soln received in safe bottles } \\
\text { 1B. SR tanker truck weighed } \\
\text { 1C. SR material sampled } \\
\text { 1D. ICPP UN soln poured } \\
\text { 1E. SR UN soln pumped to } 9212 \\
\text { 1F. SR/ICPP UN evaporated } \\
\text { 1G. Manual fill and load of UN in safe bottles } \\
\text { 1H. ICPP UO }{ }_{3} \text { received, dissolved to UN } \\
\text { 1I. Purification of UN via solvent extraction } \\
\text { 1J. Discard of raffinate to S-3 Ponds } \\
\text { 1K. Feeding of raffinate to bioreactor } \\
1 \mathrm{~L} \text {. Transport raffinate to WETF } \\
\text { 1M. Denitration of SR/ICPP UN to UO }{ }_{3} \\
\text { 1N. Maintenance on denitrator and fluid beds } \\
\text { 1O. Conversion of material to UF } \\
\text { 1P. Removal of dry UF }{ }_{4} \text { from process } \\
\text { 1Q. Bomb reduction to metal } \\
\text { 1R. Sampling, fracturing, packaging metal } \\
\text { 1S. SR U-Al salvage operations } \\
\text { 1T. Metal product shipped }\end{array}$ & $\begin{array}{c}0.11 \\
0.36 \\
0.36 \\
0.11 \\
0.36 \\
0.36 \\
0.36 \\
0.11 \\
4.5 \\
62 \\
62 \\
62 \\
0.24 \\
0.24 \\
0.24 \\
0.24 \\
0.24 \\
0.24 \\
0.23 \\
0.23\end{array}$ & $\begin{array}{c}4.7 \\
28.8 \\
28.8 \\
4.7 \\
28.8 \\
28.8 \\
28.8 \\
4.7 \\
346 \\
2980 \\
2980 \\
2980 \\
23.8 \\
23.8 \\
23.8 \\
23.8 \\
23.7 \\
23.7 \\
22.5 \\
22.5\end{array}$ & $\begin{array}{c}0.13 \\
82 \\
82 \\
0.13 \\
82 \\
82 \\
82 \\
0.13 \\
211 \\
641 \\
641 \\
641 \\
85 \\
85 \\
85 \\
85 \\
72 \\
72 \\
81 \\
81\end{array}$ & $\begin{array}{c}10 \\
27.8 \\
27.8 \\
10 \\
27.8 \\
27.8 \\
27.8 \\
10 \\
27.8 \\
27.8 \\
27.8 \\
27.8 \\
27.8 \\
27.8 \\
27.8 \\
27.8 \\
27.8 \\
27.8 \\
27.8 \\
27.8\end{array}$ & $\begin{array}{l}2 \\
3 \\
3 \\
2 \\
3 \\
3 \\
3 \\
2 \\
3 \\
3 \\
3 \\
3 \\
3 \\
3 \\
2 \\
3 \\
3 \\
3 \\
3 \\
3\end{array}$ & $\begin{array}{l}0 \\
0 \\
0 \\
1 \\
0 \\
1 \\
1 \\
2 \\
1 \\
1 \\
1 \\
1 \\
1 \\
3 \\
3 \\
3 \\
3 \\
2 \\
1 \\
0\end{array}$ & $\begin{array}{l}1 \\
1 \\
1 \\
1 \\
1 \\
2 \\
2 \\
1 \\
3 \\
1 \\
1 \\
1 \\
2 \\
1 \\
1 \\
1 \\
1 \\
1 \\
1 \\
2\end{array}$ & $\begin{array}{c}\text { no sig } \\
\text { no sig } \\
\text { no sig } \\
\text { low } \\
\text { no sig } \\
\text { mod } \\
\text { mod } \\
\text { mod } \\
\text { mod } \\
\text { mod } \\
\text { mod } \\
\text { mod } \\
\text { mod } \\
\text { mod } \\
\text { mod } \\
\text { mod } \\
\text { mod } \\
\text { mod } \\
\text { mod } \\
\text { no sig }\end{array}$ \\
\hline
\end{tabular}


RU Occupational Exposure Potential at the Y-12 Complex

\begin{tabular}{|c|c|c|c|c|c|c|c|c|}
\hline \multirow{2}{*}{ Y-12 HEU Activity } & \multicolumn{4}{|c|}{$\begin{array}{c}\text { Stream } \\
\text { Composition, U Basis }\end{array}$} & \multicolumn{4}{|c|}{$\begin{array}{l}\text { Exposure } \\
\text { Potential }\end{array}$} \\
\hline & $\begin{array}{l}\mathrm{Pu} \\
\mathrm{ppb}\end{array}$ & $\begin{array}{c}\mathrm{Np} \\
\mathrm{ppm}\end{array}$ & $\begin{array}{l}\text { Tc } \\
\mathrm{ppm}\end{array}$ & $\begin{array}{c}{ }^{236} \mathrm{U} \\
\%\end{array}$ & $\begin{array}{c}\text { Constit. } \\
\text { Level }\end{array}$ & $\begin{array}{l}\text { Airborne } \\
\text { Potential }\end{array}$ & $\begin{array}{l}\text { Exposure } \\
\text { Duration }\end{array}$ & $\begin{array}{c}\text { Occ. } \\
\text { Expossure }\end{array}$ \\
\hline \multicolumn{9}{|l|}{ Activities with Bldg 9206} \\
\hline 2A. SRS UN soln poured into safe bottles & 0.36 & 28.8 & 82 & 27.8 & 3 & 1 & 1 & $\bmod$ \\
\hline 2B. SRS U-Al ingots received & 0.23 & 22.5 & 82 & 27.8 & 3 & 0 & 1 & no sig \\
\hline 2C. SRS dross and sweepings received & 0.23 & 22.5 & 82 & 27.8 & 3 & 0 & 1 & no sig \\
\hline 2D. SRS U-Al dissolved in $\mathrm{NaOH}$ & 0.23 & 22.5 & 82 & 27.8 & 3 & 1 & 2 & $\bmod$ \\
\hline 2E. SRS sodium diuranate dissolved in acid & 0.23 & 22.5 & 82 & 27.8 & 3 & 1 & 2 & $\bmod$ \\
\hline 2F. ICPP $\cup_{3}$ received, dissolved to UN & 0.11 & 4.7 & 130 & 10 & 2 & 2 & 1 & $\bmod$ \\
\hline 2G. Purification of UN & 4.5 & 346 & 211 & 27.8 & 3 & 1 & 3 & mod \\
\hline 2H. Isolating, trucking, piping raff to 9212 & 62.4 & 2980 & 641 & 27.8 & 3 & 1 & 1 & $\bmod$ \\
\hline 21. Denitration of SR/ICPP UN to $\mathrm{UO}_{3}$ & 0.24 & 23.8 & 85 & 27.8 & 3 & 1 & 2 & $\bmod$ \\
\hline 2J. Maintenance on denitrators or fluid beds & 0.24 & 23.8 & 85 & 27.8 & 3 & 3 & 1 & $\bmod$ \\
\hline 2K. Conversion of material to $\mathrm{UF}_{4}$ & 0.24 & 23.8 & 85 & 27.8 & 3 & 3 & 1 & $\bmod$ \\
\hline 2L. Removal of dry UF & 0.24 & 23.8 & 85 & 27.8 & 3 & 2 & 1 & $\bmod$ \\
\hline 2M. Bomb reduction to metal & 0.24 & 23.7 & 85 & 27.8 & 3 & 3 & 1 & $\bmod$ \\
\hline \multicolumn{9}{|l|}{ Other Activities } \\
\hline 3A. Closure of S-3 Ponds & 1.4 & 65.9 & 200 & 3.0 & 3 & 2 & 1 & $\bmod$ \\
\hline 3B. Treatment of nitrate waste & 1.4 & 65.9 & 200 & 3.0 & 3 & 1 & 2 & mod \\
\hline 3C. RU material stored & 0.24 & 23.7 & 85 & 27.8 & 3 & 0 & 1 & no sig \\
\hline
\end{tabular}




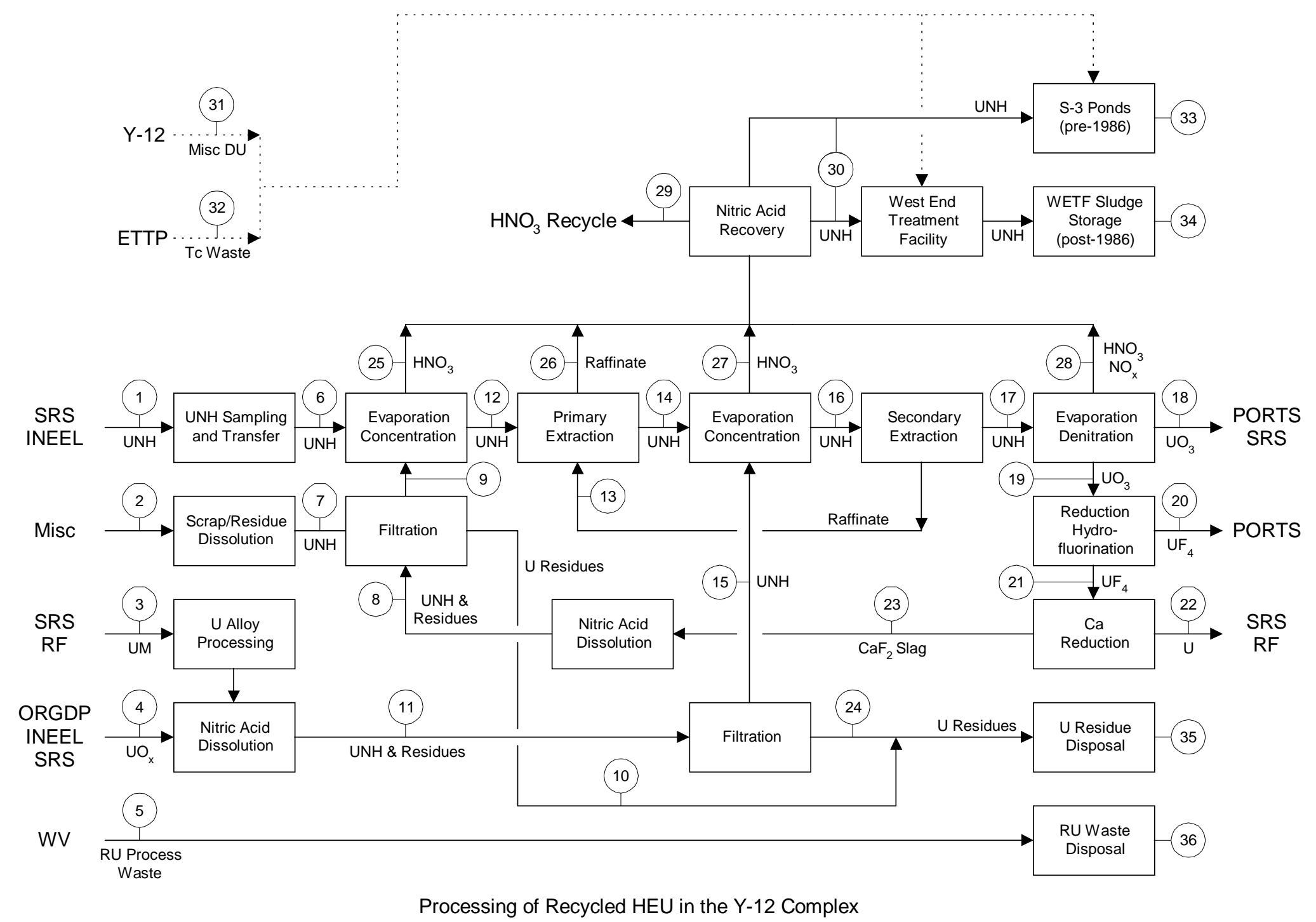




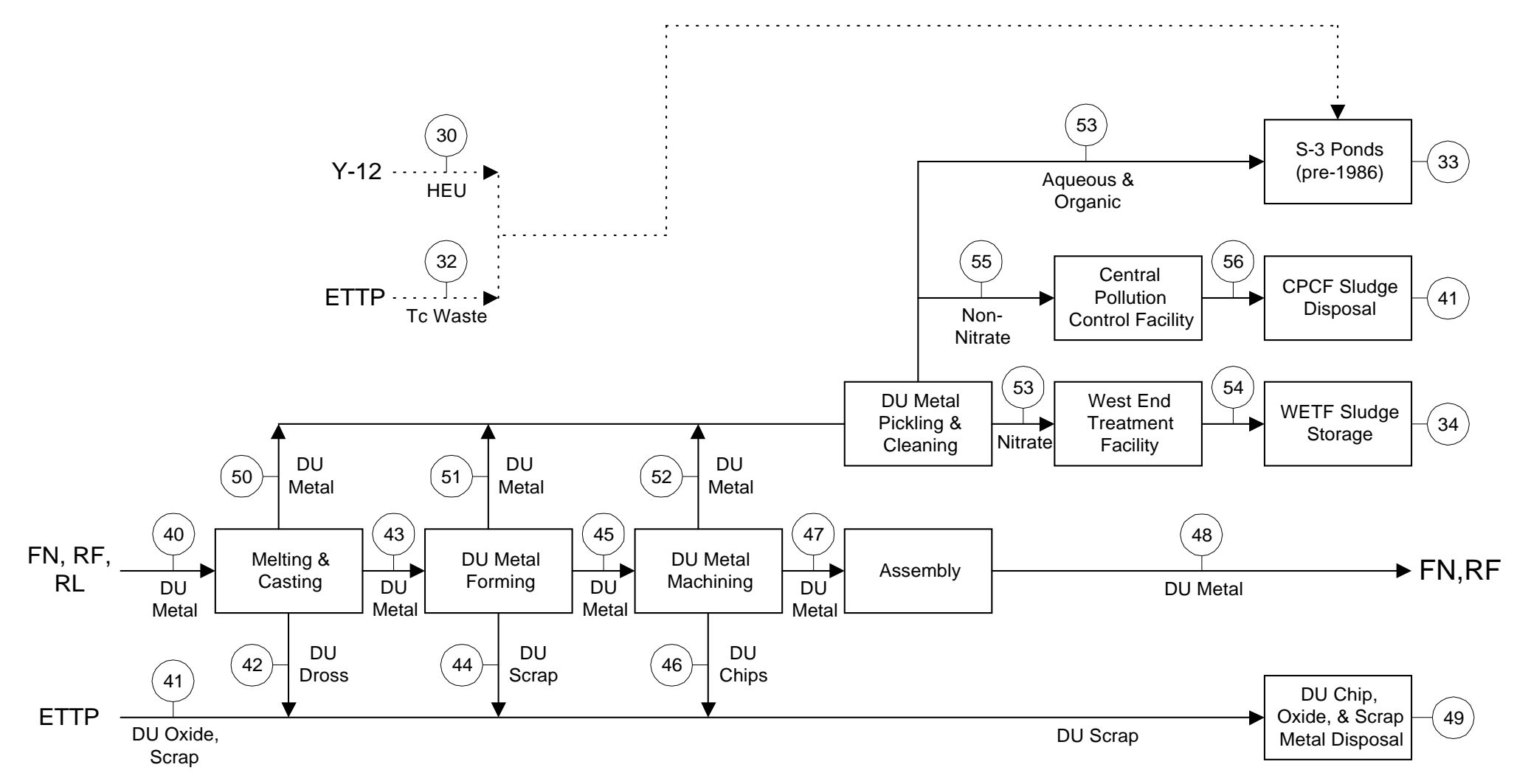

Processing of Recycled DU in the Y-12 Plant 


\section{Processing of Recycled HEU}

SRS RHEU Material Flow through $\mathrm{Y}-12$

Steady State Flow Model (manual calc procedure to converge on recycle streams)

\begin{tabular}{|c|c|c|c|c|c|c|c|c|c|c|}
\hline \multicolumn{6}{|c|}{ Feed Stream Definition, mass flows } & \multicolumn{4}{|c|}{ Feed Stream Definition, concentration } & \multirow[b]{2}{*}{ Data Source } \\
\hline & \begin{tabular}{l|l} 
MTU \\
\end{tabular} & $\mathrm{Pu}, \mathrm{gms}$ & $\mathrm{Np}, \mathrm{gms}$ & Tc, gms & Th, gms & $\mathrm{Pu}, \mathrm{ppb}$ & $\mathrm{Np}, \mathrm{ppb}$ & $\mathrm{Tc}, \mathrm{ppb}$ & Th, ppb & \\
\hline $\mathrm{UNH}$ & 125.2 & 0.0455 & 3600 & 10260 & & 0.363 & 28754 & 81949 & 0 & Y-12 \& SRS Analysis \\
\hline UO3 & 0.00 & 0.0000 & 0.00 & 0.00 & & 0.00 & 0.00 & 0.00 & 0 & \\
\hline U metal & & & & & & 0 & 0 & 0 & & \\
\hline U-Al & & & & & & 0 & 0 & 0 & & \\
\hline UF4 & & & & & & 0 & 0 & 0 & & \\
\hline Residues & & & & & & 0 & 0 & 0 & & \\
\hline Other & 0 & 0 & 0 & 0 & & 0 & 0 & 0 & 0 & \\
\hline Totals & 125.2 & 0.0455 & 3600 & 10260 & & 0.363 & 28754 & 81949 & & \\
\hline
\end{tabular}

\section{Feed Stream Concentrations}

\begin{tabular}{|c|c|c|c|c|c|c|c|c|c|c|c|c|}
\hline & $\mathrm{Pu}, \mathrm{ppb} / \mathrm{U}$ & $\mathrm{Np}, \mathrm{ppb} / \mathrm{U}$ & Tc, ppb/U & U-234 \% & U-235 \% & U-236 \% & U-238 \% & Pu-238 \% & Pu-239 \% & Pu-240 \% & Pu-241\% & Pu-242 \% \\
\hline UNH & 0.363 & 28754 & 81949 & 1.39 & 62.6 & 27.8 & 8.21 & 84 & 14 & 2 & 0 & 0 \\
\hline UO3 & 0.000 & 0 & 0 & 1.39 & 62.6 & 27.8 & 8.21 & 84 & 14 & 2 & 0 & 0 \\
\hline U metal & 0 & 0 & 0 & & & & 100 & & & & & \\
\hline U-AI & 0 & 0 & 0 & & & & 100 & & & & & \\
\hline UF4 & 0 & 0 & 0 & & & & 100 & & & & & \\
\hline Residues & 0 & 0 & 0 & & & & 100 & & & & & \\
\hline Other & 0 & 0 & 0 & & & & 100 & & & & & \\
\hline Average & 0.363 & 28754 & 81949 & 1.39 & 62.6 & 27.8 & 8.21 & 84 & 14 & 2 & 0 & 0 \\
\hline
\end{tabular}

\begin{tabular}{|lr|}
\hline U Mix Specific Activity \\
\hline $\mathrm{dpm} / \mathrm{g} \mathrm{U}$ & $2.35 \mathrm{E}+08$ \\
$\mu \mathrm{Ci} / \mathrm{g} \mathrm{U}$ & $1.06 \mathrm{E}+02$ \\
\hline
\end{tabular}

\begin{tabular}{|ll|}
\hline Pu Mix Specific Activity \\
\hline $\mathrm{dpm} / \mathrm{g} \mathrm{Pu}$ & $3.27 \mathrm{E}+13$ \\
$\mu \mathrm{Ci} / \mathrm{g} \mathrm{Pu}$ & $1.47 \mathrm{E}+07$ \\
\hline
\end{tabular}

\begin{tabular}{|l|r|r|r|r|c|}
\hline Other Specific Activity & \multicolumn{1}{|c|}{ Dep U } & Nat U & \multicolumn{1}{c|}{$93 \% \mathrm{U}$} \\
\hline & Np-237 & Tc-99 & \multicolumn{1}{c|}{ Dep } & Nat \\
$\mathrm{dpm} / \mathrm{g}$ & $1.56 \mathrm{E}+09$ & $3.76 \mathrm{E}+10$ & $9.00 \mathrm{E}+05$ & $1.50 \mathrm{E}+06$ & $1.40 \mathrm{E}+08$ \\
$\mu \mathrm{Ci} / \mathrm{g}$ & $7.04 \mathrm{E}+02$ & $1.69 \mathrm{E}+04$ & $4.05 \mathrm{E}-01$ & $6.76 \mathrm{E}-01$ & $6.31 \mathrm{E}+01$ \\
$\mathrm{Ci} / \mathrm{g}$ & $7.04 \mathrm{E}-04$ & $1.69 \mathrm{E}-02$ & $4.05 \mathrm{E}-07$ & $6.76 \mathrm{E}-07$ & $6.31 \mathrm{E}-05$ \\
& & & & & \\
& & & & & \\
\hline
\end{tabular}

\begin{tabular}{|l|r|}
\hline \multicolumn{2}{|c|}{$\beta$ Activity of non-RU } \\
\hline & dpm/ $\mu \mathrm{gU}$ \\
\hline Th-234 & 0.0670 \\
$\mathrm{~Pa}-234$ & 0.0670 \\
Th-231 & 4.3197 \\
\hline Total & 4.454 \\
\hline
\end{tabular}




\begin{tabular}{|c|c|c|c|c|c|c|c|c|c|c|c|c|}
\hline \multicolumn{10}{|c|}{ Feed Stream Activity } & \multicolumn{3}{|c|}{ RU Comparison to WU } \\
\hline & $\mathrm{U}, \mathrm{ci}$ & $\mathrm{Pu}, \mathrm{ci}$ & $\mathrm{dpm} / \mu \mathrm{gU}$ & $\mathrm{Np}, \mathrm{ci}$ & $\mathrm{dpm} / \mu \mathrm{gU}$ & Tc, ci & $\mathrm{dpm} / \mu \mathrm{gU}$ & Th, ci & $\mathrm{dpm} / \mu \mathrm{gU}$ & $\alpha$ Ratio & $\beta$ Ratio & $\gamma$ Ratio \\
\hline UNH & $1.33 \mathrm{E}+04$ & 6.69E-01 & $1.19 \mathrm{E}-02$ & $2.53 \mathrm{E}+00$ & $4.49 \mathrm{E}-02$ & $1.73 \mathrm{E}+02$ & $3.07 \mathrm{E}+00$ & & & 0.2840 & 0.6903 & \\
\hline UO3 & $0.00 \mathrm{E}+00$ & $0.00 \mathrm{E}+00$ & $0.00 \mathrm{E}+00$ & $0.00 \mathrm{E}+00$ & $0.00 \mathrm{E}+00$ & $0.00 \mathrm{E}+00$ & $0.00 \mathrm{E}+00$ & & & 0.0000 & 0.0000 & \\
\hline U metal & $0.00 \mathrm{E}+00$ & $0.00 \mathrm{E}+00$ & $0.00 \mathrm{E}+00$ & $0.00 \mathrm{E}+00$ & $0.00 \mathrm{E}+00$ & $0.00 \mathrm{E}+00$ & $0.00 \mathrm{E}+00$ & & & 0 & 0 & \\
\hline U-Al & $0.00 \mathrm{E}+00$ & $0.00 \mathrm{E}+00$ & $0.00 \mathrm{E}+00$ & $0.00 \mathrm{E}+00$ & $0.00 \mathrm{E}+00$ & $0.00 \mathrm{E}+00$ & $0.00 \mathrm{E}+00$ & & & 0 & 0 & \\
\hline UF4 & $0.00 \mathrm{E}+00$ & $0.00 \mathrm{E}+00$ & $0.00 \mathrm{E}+00$ & $0.00 \mathrm{E}+00$ & $0.00 \mathrm{E}+00$ & $0.00 \mathrm{E}+00$ & $0.00 \mathrm{E}+00$ & & & 0 & 0 & \\
\hline Residues & $0.00 \mathrm{E}+00$ & $0.00 \mathrm{E}+00$ & $0.00 \mathrm{E}+00$ & $0.00 \mathrm{E}+00$ & $0.00 \mathrm{E}+00$ & $0.00 \mathrm{E}+00$ & $0.00 \mathrm{E}+00$ & & & 0 & 0 & \\
\hline Other & $0.00 \mathrm{E}+00$ & $0.00 \mathrm{E}+00$ & $0.00 \mathrm{E}+00$ & $0.00 \mathrm{E}+00$ & $0.00 \mathrm{E}+00$ & $0.00 \mathrm{E}+00$ & $0.00 \mathrm{E}+00$ & & & 0.0000 & 0.00000 & \\
\hline Totals & $1.33 \mathrm{E}+04$ & $6.69 \mathrm{E}-01$ & $1.19 \mathrm{E}-02$ & $2.53 \mathrm{E}+00$ & $4.49 \mathrm{E}-02$ & $1.73 \mathrm{E}+02$ & $3.07 \mathrm{E}+00$ & & & 0.2840 & 0.6903 & \\
\hline
\end{tabular}

Notes:

$\alpha$ Ratio $=$ (activity of $\mathrm{Pu}+\mathrm{Np}$ per gram $\mathrm{U}$ )/nominal specific activity of $\mathrm{EU}^{*} 700$

$\beta$ Ratio = beta activity of sample per gram $\mathrm{U} /$ nominal specific beta activity of unirradiated EU

$\gamma$ Ratio $=\mu$ gram Ra-226 equivalent $/$ gram $U$ 


\begin{tabular}{|c|c|c|c|c|c|c|c|c|c|c|}
\hline \multicolumn{11}{|c|}{ Chemical Process Assumptions } \\
\hline \multirow[b]{2}{*}{ Process Step } & \multicolumn{2}{|c|}{ Distribution of $U$} & \multicolumn{2}{|c|}{ Distribution of $\mathrm{Pu}$} & \multicolumn{2}{|c|}{ Distribution of $\mathrm{Np}$} & \multicolumn{2}{|c|}{ Distribution of Tc } & \multicolumn{2}{|c|}{ Distribution of Th } \\
\hline & Product & Raffinate & Product & Raffinate & Product & Raffinate & Product & Raffinate & Product & Raffinate \\
\hline HNO3 Dissolver & 1 & 0 & 1 & 0 & 1 & 0 & 1 & 0 & 1 & 0 \\
\hline Liquid/Solids Filter & 0.98 & 0.02 & 0.9 & 0.1 & 0.9 & 0.1 & 0.9 & 0.1 & 0.9 & 0.1 \\
\hline Primary Evaporator & 0.999 & 0.001 & 0.99 & 0.01 & 0.99 & 0.01 & 0.99 & 0.01 & 0.99 & 0.01 \\
\hline Primary Extraction & 0.99999 & 0.00001 & 0.7 & 0.3 & 0.8 & 0.2 & 0.98 & 0.02 & 0.99 & 0.01 \\
\hline Second Evaporator & 0.999 & 0.001 & 0.99 & 0.01 & 0.99 & 0.01 & 0.99 & 0.01 & 0.99 & 0.01 \\
\hline Second Extraction & 0.99 & 0.01 & 0.4 & 0.6 & 0.5 & 0.5 & 0.95 & 0.05 & 0.9 & 0.1 \\
\hline Denitration & 0.999 & 0.001 & 0.999 & 0.001 & 0.995 & 0.005 & 0.999 & 0.001 & 0.999 & 0.001 \\
\hline H2/HF Fluid Beds & 1 & 0 & 1 & 0 & 1 & 0 & 1 & 0 & 1 & 0 \\
\hline Ca Reduction & 0.95 & 0.05 & 0.9 & 0.1 & 0.9 & 0.1 & 0.9 & 0.1 & 0.95 & 0.05 \\
\hline HNO3 Still to Recycle & 0.001 & 0.999 & 0.001 & 0.999 & 0.001 & 0.999 & 0.001 & 0.999 & 0.001 & 0.999 \\
\hline Fraction UO3 Product & 0 & 1 & 0 & 1 & 0 & 1 & 0 & 1 & 0 & 1 \\
\hline Fraction UF4 Product & 0 & 1 & 0 & 1 & 0 & 1 & 0 & 1 & 0 & 1 \\
\hline Fraction to WETF & 0 & 1 & 0 & 1 & 0 & 1 & 0 & 1 & 0 & 1 \\
\hline
\end{tabular}

\begin{tabular}{|c|c|c|c|c|c|c|c|c|c|c|c|}
\hline \multicolumn{12}{|c|}{ Process Stream Flows } \\
\hline \multirow[b]{2}{*}{ Stream Component } & \multicolumn{11}{|c|}{ Stream Number } \\
\hline & 1 & 2 & 3 & 4 & 5 & 6 & 7 & 9 & 10 & 11 est & $11^{*}$ \\
\hline $\mathrm{U}, \mathrm{kgs}$ & $0.00 \mathrm{E}+00$ & $0.00 \mathrm{E}+00$ & $0.00 \mathrm{E}+00$ & $0.00 \mathrm{E}+00$ & $1.25 \mathrm{E}+05$ & $0.00 \mathrm{E}+00$ & $0.00 \mathrm{E}+00$ & $0.00 \mathrm{E}+00$ & $1.25 \mathrm{E}+05$ & $1.31 \mathrm{E}+03$ & 1329.707 \\
\hline $\mathrm{Pu}, \mathrm{gms}$ & $0.00 \mathrm{E}+00$ & $0.00 \mathrm{E}+00$ & $0.00 \mathrm{E}+00$ & $0.00 \mathrm{E}+00$ & 4.55E-02 & $0.00 \mathrm{E}+00$ & $0.00 \mathrm{E}+00$ & $0.00 \mathrm{E}+00$ & 4.55E-02 & $2.81 \mathrm{E}-02$ & 0.048205 \\
\hline $\mathrm{Np}, \mathrm{gms}$ & $0.00 \mathrm{E}+00$ & $0.00 \mathrm{E}+00$ & $0.00 \mathrm{E}+00$ & $0.00 \mathrm{E}+00$ & $3.60 \mathrm{E}+03$ & $0.00 \mathrm{E}+00$ & $0.00 \mathrm{E}+00$ & $0.00 \mathrm{E}+00$ & $3.60 \mathrm{E}+03$ & $1.87 \mathrm{E}+03$ & 3134.245 \\
\hline Tc, gms & $0.00 \mathrm{E}+00$ & $0.00 \mathrm{E}+00$ & $0.00 \mathrm{E}+00$ & $0.00 \mathrm{E}+00$ & $1.03 E+04$ & $0.00 \mathrm{E}+00$ & $0.00 \mathrm{E}+00$ & $0.00 \mathrm{E}+00$ & $1.03 E+04$ & $5.56 \mathrm{E}+02$ & 590.61637 \\
\hline \multirow[t]{3}{*}{ Th, gms } & $0.00 \mathrm{E}+00$ & $0.00 \mathrm{E}+00$ & $0.00 \mathrm{E}+00$ & $0.00 \mathrm{E}+00$ & $0.00 \mathrm{E}+00$ & $0.00 \mathrm{E}+00$ & $0.00 \mathrm{E}+00$ & $0.00 \mathrm{E}+00$ & $0.00 \mathrm{E}+00$ & $0.00 \mathrm{E}+00$ & 0.0000 \\
\hline & & & & & & $0.00 \mathrm{E}+00$ & $0.00 \mathrm{E}+00$ & $0.00 \mathrm{E}+00$ & $0.00 \mathrm{E}+00$ & $0.00 \mathrm{E}+00$ & \\
\hline & & & & & & $0.00 \mathrm{E}+00$ & $0.00 \mathrm{E}+00$ & $0.00 \mathrm{E}+00$ & $0.00 \mathrm{E}+00$ & $0.00 \mathrm{E}+00$ & \\
\hline
\end{tabular}

*Loop 1, manually enter "11 Est." values, then use "11 Calc" values $n$ times for convergence of stream "11" with "11 Calc". Go to Loop 2. 


\begin{tabular}{|c|c|c|c|c|c|c|c|c|c|c|c|}
\hline \multicolumn{12}{|c|}{ Process Stream Flows } \\
\hline \multirow[b]{2}{*}{ Stream Component } & \multicolumn{11}{|c|}{ Stream Number } \\
\hline & 12 & 13 est & $13^{* *}$ & 14 & 15 & 16 & $11 \mathrm{calc}^{*}$ & 17 & 18 & 19 & 20 \\
\hline $\mathrm{U}, \mathrm{kgs}$ & 1328.38 & 6250.634 & 6575.4656 & $7.90 \mathrm{E}+03$ & $1.25 \mathrm{E}+05$ & $1.33 \mathrm{E}+05$ & 1329.7066 & $1.32 \mathrm{E}+05$ & $0.00 \mathrm{E}+00$ & $1.32 \mathrm{E}+05$ & $0.00 \mathrm{E}+00$ \\
\hline $\mathrm{Pu}, \mathrm{gms}$ & 0.05 & 0.0031216 & 0.0032105 & 3.57E-02 & 4.55E-02 & 8.03E-02 & 0.0482053 & $3.21 \mathrm{E}-02$ & $0.00 \mathrm{E}+00$ & 3.21E-02 & $0.00 \mathrm{E}+00$ \\
\hline $\mathrm{Np}, \mathrm{gms}$ & 3102.90 & 299.56957 & 311.857400 & $2.73 E+03$ & $3.60 \mathrm{E}+03$ & $6.27 \mathrm{E}+03$ & 3134.2449 & $3.13 \mathrm{E}+03$ & $0.00 \mathrm{E}+00$ & $3.12 \mathrm{E}+03$ & $0.00 \mathrm{E}+00$ \\
\hline Tc, gms & 584.71 & 1017.8263 & 1121.0489 & 1.67E+03 & $1.03 \mathrm{E}+04$ & $1.18 \mathrm{E}+04$ & 590.61637 & $1.12 \mathrm{E}+04$ & $0.00 \mathrm{E}+00$ & $1.12 \mathrm{E}+04$ & $0.00 \mathrm{E}+00$ \\
\hline \multirow[t]{3}{*}{ Th, gms } & 0.00 & 0 & 0 & $0.00 \mathrm{E}+00$ & $0.00 \mathrm{E}+00$ & $0.00 \mathrm{E}+00$ & 0 & $0.00 \mathrm{E}+00$ & $0.00 \mathrm{E}+00$ & $0.00 \mathrm{E}+00$ & $0.00 \mathrm{E}+00$ \\
\hline & 0.00 & 0 & 0 & $0.00 \mathrm{E}+00$ & $0.00 \mathrm{E}+00$ & 0 & 0 & $0.00 \mathrm{E}+00$ & $0.00 \mathrm{E}+00$ & $0.00 \mathrm{E}+00$ & $0.00 \mathrm{E}+00$ \\
\hline & 0.00 & 0 & 0 & $0.00 \mathrm{E}+00$ & $0.00 \mathrm{E}+00$ & 0 & 0 & $0.00 \mathrm{E}+00$ & $0.00 \mathrm{E}+00$ & $0.00 \mathrm{E}+00$ & $0.00 \mathrm{E}+00$ \\
\hline
\end{tabular}

${ }^{\star \star}$ Loop 2 (after convergence of Loop 1), manually enter "13 Est." values, then use "23" values m times for convergence of "13" with "23".

Go back to Loop 1 as required for overall convergence.

\begin{tabular}{|c|c|c|c|c|c|c|c|c|c|c|c|}
\hline \multicolumn{12}{|c|}{ Process Stream Flows } \\
\hline \multirow[b]{2}{*}{ Stream Component } & \multicolumn{11}{|c|}{ Stream Number } \\
\hline & 21 & 22 & $23^{* *}$ & 25 & 26 & 27 & 28 & 29 & 30 & 31 & 32 \\
\hline $\mathrm{U}, \mathrm{kgs}$ & $1.32 \mathrm{E}+05$ & $1.25 \mathrm{E}+05$ & 6575.4656 & $1.33 \mathrm{E}+00$ & $7.90 \mathrm{E}-02$ & $1.33 \mathrm{E}+02$ & $1.32 \mathrm{E}+02$ & $2.66 \mathrm{E}-01$ & $2.66 \mathrm{E}+02$ & $1.20 \mathrm{E}+04$ & $1.00 \mathrm{E}+02$ \\
\hline $\mathrm{Pu}, \mathrm{gms}$ & 3.21E-02 & 2.89E-02 & 0.0032105 & $4.82 \mathrm{E}-04$ & $1.53 \mathrm{E}-02$ & 8.12E-04 & $3.21 \mathrm{E}-05$ & 1.66E-05 & 1.66E-02 & 7.88E-05 & $0.00 \mathrm{E}+00$ \\
\hline $\mathrm{Np}, \mathrm{gms}$ & $3.12 \mathrm{E}+03$ & $2.81 E+03$ & 311.857372 & $3.13 \mathrm{E}+01$ & $6.83 \mathrm{E}+02$ & $6.33 \mathrm{E}+01$ & 1.57E+01 & 7.93E-01 & $7.92 \mathrm{E}+02$ & 3.10E-02 & $2.30 \mathrm{E}+01$ \\
\hline Tc, gms & $1.12 \mathrm{E}+04$ & $1.01 \mathrm{E}+04$ & 1121.0489 & $5.91 \mathrm{E}+00$ & $3.41 \mathrm{E}+01$ & $1.19 \mathrm{E}+02$ & $1.12 \mathrm{E}+01$ & $1.71 \mathrm{E}-01$ & $1.70 \mathrm{E}+02$ & $1.09 \mathrm{E}-01$ & $2.30 \mathrm{E}+03$ \\
\hline \multirow[t]{3}{*}{ Th, gms } & $0.00 \mathrm{E}+00$ & $0.00 \mathrm{E}+00$ & 0 & $0.00 \mathrm{E}+00$ & $0.00 \mathrm{E}+00$ & $0.00 \mathrm{E}+00$ & $0.00 \mathrm{E}+00$ & $0.00 \mathrm{E}+00$ & $0.00 \mathrm{E}+00$ & $0.00 \mathrm{E}+00$ & $0.00 \mathrm{E}+00$ \\
\hline & $0.00 \mathrm{E}+00$ & $0.00 \mathrm{E}+00$ & & $0.00 \mathrm{E}+00$ & $0.00 \mathrm{E}+00$ & $0.00 \mathrm{E}+00$ & $0.00 \mathrm{E}+00$ & $0.00 \mathrm{E}+00$ & $0.00 \mathrm{E}+00$ & $0.00 \mathrm{E}+00$ & $0.00 \mathrm{E}+00$ \\
\hline & $0.00 \mathrm{E}+00$ & $0.00 \mathrm{E}+00$ & & $0.00 \mathrm{E}+00$ & $0.00 \mathrm{E}+00$ & $0.00 \mathrm{E}+00$ & $0.00 \mathrm{E}+00$ & $0.00 \mathrm{E}+00$ & $0.00 \mathrm{E}+00$ & $0.00 \mathrm{E}+00$ & $0.00 \mathrm{E}+00$ \\
\hline
\end{tabular}

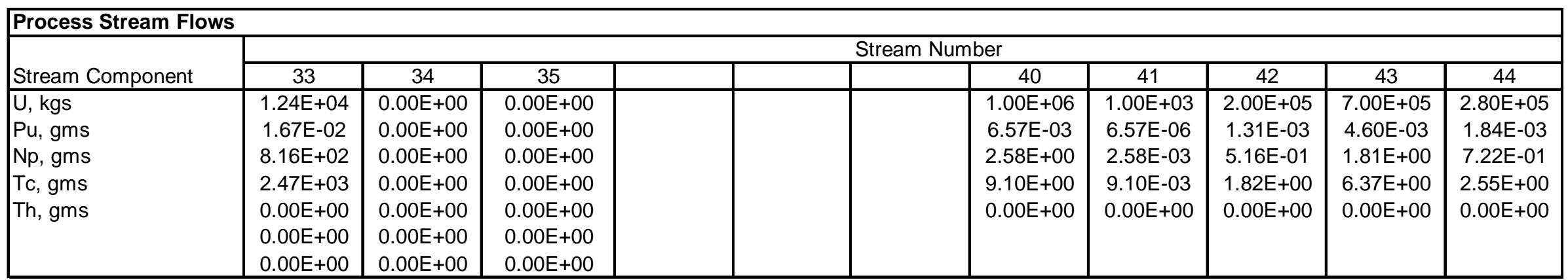




\begin{tabular}{|c|c|c|c|c|c|c|c|c|c|c|c|}
\hline \multicolumn{12}{|c|}{ Process Stream Flows } \\
\hline \multirow[b]{2}{*}{ Stream Component } & \multicolumn{11}{|c|}{ Stream Number } \\
\hline & 45 & 46 & 47 & 48 & 49 & 50 & 51 & 52 & 53 & 54 & 55 \\
\hline $\mathrm{U}, \mathrm{kgs}$ & $2.80 \mathrm{E}+05$ & $8.40 \mathrm{E}+04$ & $1.40 \mathrm{E}+05$ & $1.40 \mathrm{E}+05$ & $5.65 \mathrm{E}+05$ & $1.00 \mathrm{E}+05$ & $1.40 \mathrm{E}+05$ & $5.60 \mathrm{E}+04$ & $2.96 \mathrm{E}+05$ & $2.96 \mathrm{E}+05$ & \\
\hline $\mathrm{Pu}, \mathrm{gms}$ & 1.84E-03 & 5.52E-04 & $9.20 \mathrm{E}-04$ & $9.20 \mathrm{E}-04$ & $3.71 \mathrm{E}-03$ & 6.57E-04 & $9.20 \mathrm{E}-04$ & 3.68E-04 & 1.94E-03 & $1.94 \mathrm{E}-03$ & \\
\hline $\mathrm{Np}, \mathrm{gms}$ & 7.22E-01 & 2.17E-01 & $3.61 \mathrm{E}-01$ & $3.61 \mathrm{E}-01$ & $1.46 \mathrm{E}+00$ & $2.58 \mathrm{E}-01$ & $3.61 \mathrm{E}-01$ & $1.44 \mathrm{E}-01$ & 7.64E-01 & 7.64E-01 & \\
\hline Tc, gms & $2.55 \mathrm{E}+00$ & 7.64E-01 & $1.27 \mathrm{E}+00$ & $1.27 \mathrm{E}+00$ & $5.14 \mathrm{E}+00$ & $9.10 \mathrm{E}-01$ & $1.27 \mathrm{E}+00$ & $5.10 \mathrm{E}-01$ & $2.69 \mathrm{E}+00$ & $2.69 \mathrm{E}+00$ & \\
\hline Th, gms & $0.00 \mathrm{E}+00$ & $0.00 \mathrm{E}+00$ & $0.00 \mathrm{E}+00$ & $0.00 \mathrm{E}+00$ & $0.00 E+00$ & $0.00 \mathrm{E}+00$ & $0.00 \mathrm{E}+00$ & $0.00 \mathrm{E}+00$ & $0.00 \mathrm{E}+00$ & $0.00 \mathrm{E}+00$ & \\
\hline
\end{tabular}

\begin{tabular}{|l|c|c|c|c|c|c|}
\hline Mass Balance Checks & \multicolumn{7}{|c|}{ Stream Comparison } \\
\hline \multirow{3}{*}{ Stream Component } & Out-In & $\%$ Input & Str 11a-11 & $\%$ Str 11 & Str23-13 & $\%$ Str 13 \\
\cline { 2 - 7 } & 0.0000 & 0.0000 & 0.0000 & 0.0000 & 0.0000 & 0.0000 \\
U, kgs & 0.0000 & 0.0002 & 0.0000 & -0.0001 & 0.0000 & -0.0009 \\
Pu, gms & 0.0001 & 0.0000 & -0.0001 & 0.0000 & 0.0000 & 0.0000 \\
Np, gms & 0.0000 & 0.0000 & 0.0000 & 0.0000 & 0.0000 & 0.0000 \\
Tc, gms & 0.0000 & 0.0000 & 0.0000 & 0.0000 & 0.0000 & 0.0000 \\
Th, gms & & & & & & \\
& & & & & & \\
\hline
\end{tabular}

\begin{tabular}{|c|c|c|c|}
\hline \multicolumn{4}{|c|}{ Component Distribution } \\
\hline Fract Res & Fract Sdg & Fract Pro & Totals \\
\hline 0.0000 & 0.0901 & 0.9099 & 1.0000 \\
0.0000 & 0.3657 & 0.6339 & 0.9996 \\
0.0000 & 0.2251 & 0.7747 & 0.9998 \\
0.0000 & 0.1967 & 0.8033 & 1.0000 \\
0.0000 & 0.0000 & 0.0000 & 0.0000 \\
& & & \\
& & & \\
\hline
\end{tabular}

\begin{tabular}{|c|c|c|c|c|c|c|c|c|c|c|c|}
\hline \multicolumn{12}{|c|}{ Process Stream Concentrations on U Basis } \\
\hline \multirow[b]{2}{*}{ Stream Component } & \multicolumn{11}{|c|}{ Stream Number } \\
\hline & 1 & 2 & 3 & 4 & 5 & 6 & 7 & 9 & 10 & 11 est & 11 \\
\hline $\mathrm{U}, \mathrm{kgs}$ & $0.00 \mathrm{E}+00$ & $0.00 \mathrm{E}+00$ & $0.00 \mathrm{E}+00$ & $0.00 \mathrm{E}+00$ & $1.25 \mathrm{E}+05$ & $0.00 \mathrm{E}+00$ & $0.00 \mathrm{E}+00$ & $0.00 \mathrm{E}+00$ & $1.25 \mathrm{E}+05$ & $1.31 \mathrm{E}+03$ & $1.33 \mathrm{E}+03$ \\
\hline $\mathrm{Pu}, \mathrm{ppb} / \mathrm{U}$ & $0.00 \mathrm{E}+00$ & $0.00 \mathrm{E}+00$ & $0.00 \mathrm{E}+00$ & $0.00 \mathrm{E}+00$ & 3.63E-01 & $0.00 \mathrm{E}+00$ & $0.00 \mathrm{E}+00$ & $0.00 \mathrm{E}+00$ & 3.63E-01 & $2.14 \mathrm{E}+01$ & $3.63 E+01$ \\
\hline $\mathrm{Np}, \mathrm{ppb} / \mathrm{U}$ & $0.00 \mathrm{E}+00$ & $0.00 \mathrm{E}+00$ & $0.00 \mathrm{E}+00$ & $0.00 \mathrm{E}+00$ & $2.88 \mathrm{E}+04$ & $0.00 E+00$ & $0.00 E+00$ & $0.00 E+00$ & $2.88 \mathrm{E}+04$ & $1.42 \mathrm{E}+06$ & $2.36 \mathrm{E}+06$ \\
\hline Tc, ppb/U & $0.00 \mathrm{E}+00$ & $0.00 \mathrm{E}+00$ & $0.00 E+00$ & $0.00 \mathrm{E}+00$ & $8.19 E+04$ & $0.00 E+00$ & $0.00 E+00$ & $0.00 E+00$ & $8.19 E+04$ & $4.23 E+05$ & $4.44 \mathrm{E}+05$ \\
\hline Th, ppb/U & $0.00 \mathrm{E}+00$ & $0.00 \mathrm{E}+00$ & $0.00 E+00$ & $0.00 \mathrm{E}+00$ & $0.00 \mathrm{E}+00$ & $0.00 E+00$ & $0.00 E+00$ & $0.00 E+00$ & $0.00 E+00$ & $0.00 \mathrm{E}+00$ & $0.00 E+00$ \\
\hline
\end{tabular}

B-11 


\begin{tabular}{|c|c|c|c|c|c|c|c|c|c|c|c|}
\hline \multicolumn{12}{|c|}{ Process Stream Concentrations on U Basis } \\
\hline \multirow[b]{2}{*}{ Stream Component } & \multicolumn{11}{|c|}{ Stream Number } \\
\hline & 12 & 13 est & 13 & 14 & 15 & 16 & $11 \mathrm{cal}$ & 17 & 18 & 19 & 20 \\
\hline $\mathrm{U}, \mathrm{kgs}$ & $1.33 \mathrm{E}+03$ & $6.25 \mathrm{E}+03$ & $6.58 \mathrm{E}+03$ & $7.90 \mathrm{E}+03$ & $1.25 \mathrm{E}+05$ & $1.33 \mathrm{E}+05$ & $1.33 \mathrm{E}+03$ & $1.32 \mathrm{E}+05$ & $0.00 \mathrm{E}+00$ & $1.32 \mathrm{E}+05$ & $0.00 \mathrm{E}+00$ \\
\hline $\mathrm{Pu}, \mathrm{ppb} / \mathrm{U}$ & $3.59 \mathrm{E}+01$ & 4.99E-01 & 4.88E-01 & $4.51 \mathrm{E}+00$ & 3.63E-01 & $6.04 \mathrm{E}-01$ & $3.63 E+01$ & 2.44E-01 & $0.00 \mathrm{E}+00$ & $2.44 \mathrm{E}-01$ & $0.00 \mathrm{E}+00$ \\
\hline $\mathrm{Np}, \mathrm{ppb} / \mathrm{U}$ & 2.34E+06 & $4.79 \mathrm{E}+04$ & $4.74 \mathrm{E}+04$ & $3.46 \mathrm{E}+05$ & $2.88 \mathrm{E}+04$ & $4.71 \mathrm{E}+04$ & $2.36 \mathrm{E}+06$ & $2.38 \mathrm{E}+04$ & $0.00 \mathrm{E}+00$ & $2.37 \mathrm{E}+04$ & $0.00 \mathrm{E}+00$ \\
\hline $\mathrm{Tc}, \mathrm{ppb} / \mathrm{U}$ & $4.40 \mathrm{E}+05$ & $1.63 \mathrm{E}+05$ & $1.70 \mathrm{E}+05$ & $2.11 \mathrm{E}+05$ & $8.19 E+04$ & $8.88 \mathrm{E}+04$ & $4.44 \mathrm{E}+05$ & $8.52 \mathrm{E}+04$ & $0.00 \mathrm{E}+00$ & $8.52 \mathrm{E}+04$ & $0.00 \mathrm{E}+00$ \\
\hline Th, ppb/U & $0.00 \mathrm{E}+00$ & $0.00 \mathrm{E}+00$ & $0.00 \mathrm{E}+00$ & $0.00 \mathrm{E}+00$ & $0.00 \mathrm{E}+00$ & $0.00 \mathrm{E}+00$ & $0.00 \mathrm{E}+00$ & $0.00 \mathrm{E}+00$ & $0.00 \mathrm{E}+00$ & $0.00 \mathrm{E}+00$ & $0.00 \mathrm{E}+00$ \\
\hline
\end{tabular}

\begin{tabular}{|c|c|c|c|c|c|c|c|c|c|c|c|}
\hline \multicolumn{12}{|c|}{ Process Stream Concentrations on U Basis } \\
\hline \multirow[b]{2}{*}{ Stream Component } & \multicolumn{11}{|c|}{ Stream Number } \\
\hline & 21 & 22 & 23 & 25 & 26 & 27 & 28 & 29 & 30 & 31 & 32 \\
\hline $\mathrm{U}, \mathrm{kgs}$ & $1.32 \mathrm{E}+05$ & $1.25 \mathrm{E}+05$ & $6.58 \mathrm{E}+03$ & $1.33 \mathrm{E}+00$ & $7.90 \mathrm{E}-02$ & $1.33 \mathrm{E}+02$ & $1.32 \mathrm{E}+02$ & $2.66 \mathrm{E}-01$ & $2.66 \mathrm{E}+02$ & $1.20 \mathrm{E}+04$ & $1.00 \mathrm{E}+02$ \\
\hline $\mathrm{Pu}, \mathrm{ppb} / \mathrm{U}$ & $2.44 \mathrm{E}-01$ & $2.31 \mathrm{E}-01$ & $4.88 \mathrm{E}-01$ & $3.63 \mathrm{E}+02$ & $1.93 \mathrm{E}+05$ & $6.10 \mathrm{E}+00$ & 2.44E-01 & $6.24 \mathrm{E}+01$ & $6.24 \mathrm{E}+01$ & $6.57 \mathrm{E}-03$ & $0.00 \mathrm{E}+00$ \\
\hline $\mathrm{Np}, \mathrm{ppb} / \mathrm{U}$ & $2.37 \mathrm{E}+04$ & $2.25 \mathrm{E}+04$ & $4.74 \mathrm{E}+04$ & $2.36 \mathrm{E}+07$ & $8.64 \mathrm{E}+09$ & 4.76E+05 & $1.19 \mathrm{E}+05$ & $2.98 \mathrm{E}+06$ & $2.98 \mathrm{E}+06$ & $2.58 \mathrm{E}+00$ & $2.30 \mathrm{E}+05$ \\
\hline $\mathrm{Tc}, \mathrm{ppb} / \mathrm{U}$ & $8.52 \mathrm{E}+04$ & $8.08 \mathrm{E}+04$ & $1.70 \mathrm{E}+05$ & $4.44 \mathrm{E}+06$ & $4.32 \mathrm{E}+08$ & $8.96 \mathrm{E}+05$ & $8.52 \mathrm{E}+04$ & $6.41 \mathrm{E}+05$ & $6.41 \mathrm{E}+05$ & $9.08 \mathrm{E}+00$ & $2.30 \mathrm{E}+07$ \\
\hline Th, ppb/U & $0.00 \mathrm{E}+00$ & $0.00 \mathrm{E}+00$ & $0.00 \mathrm{E}+00$ & $0.00 \mathrm{E}+00$ & $0.00 \mathrm{E}+00$ & $0.00 \mathrm{E}+00$ & $0.00 \mathrm{E}+00$ & $0.00 \mathrm{E}+00$ & $0.00 \mathrm{E}+00$ & $0.00 \mathrm{E}+00$ & $0.00 \mathrm{E}+00$ \\
\hline
\end{tabular}

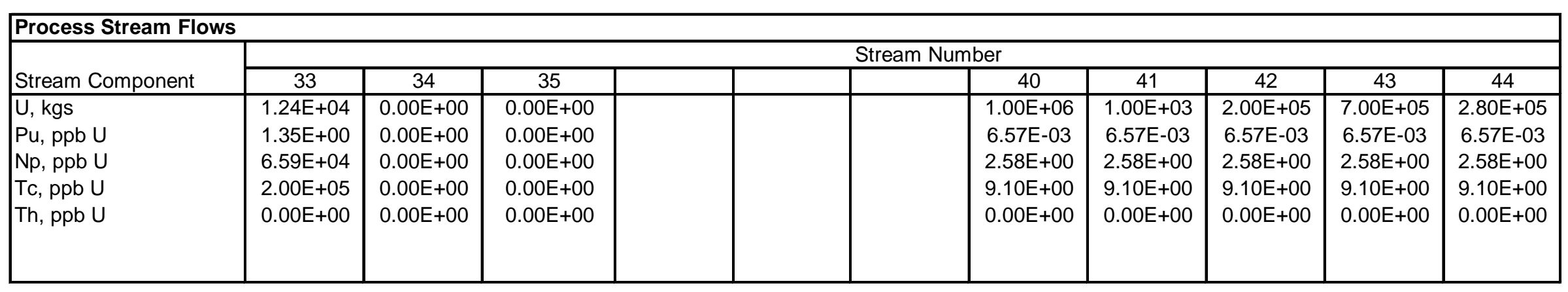




\begin{tabular}{|l|c|c|c|c|c|c|c|c|c|c|c|}
\hline \multirow{2}{*}{ Rad Component } & \multicolumn{9}{|c|}{ Stream Number } \\
\cline { 2 - 11 } & 1 & 2 & 3 & 4 & 5 & 6 & 7 & 9 & 10 & 11 est & 11 \\
\hline$\alpha$ Ratio & 0.000 & 0.000 & 0.0000 & 0.000 & 0.284 & 0.000 & 0.000 & 0.000 & 0.284 & 14.61 & 24.31 \\
$\beta$ Ratio & 0.000 & 0.000 & 0.0000 & 0.000 & 0.692 & 0.000 & 0.000 & 0.000 & 0.692 & 3.57 & 3.75 \\
$\gamma$ Ratio & & & & & & & & & & \\
\hline
\end{tabular}

\begin{tabular}{|c|c|c|c|c|c|c|c|c|c|c|c|}
\hline \multirow[b]{2}{*}{ Rad Component } & \multicolumn{11}{|c|}{ Stream Number } \\
\hline & 12 & 13 est & 13 & 14 & 15 & 16 & $11 \mathrm{cal}$ & 17 & 18 & 19 & 20 \\
\hline$\alpha$ Ratio & 24.09 & 0.455 & 0.450 & 3.433 & 0.284 & 0.466 & 24.31 & 0.226 & 0.000 & 0.225 & 0.000 \\
\hline $\begin{array}{l}\beta \text { Ratio } \\
\gamma \text { Ratio }\end{array}$ & 3.72 & 1.375 & 1.439 & 1.786 & 0.692 & 0.750 & 3.75 & 0.720 & 0.000 & 0.720 & 0.000 \\
\hline
\end{tabular}

\begin{tabular}{|l|c|c|c|c|c|c|c|c|c|c|c|}
\hline \multirow{2}{*}{ Rad Component } & \multicolumn{9}{|c|}{ Stream Number } \\
\cline { 2 - 17 } & 21 & 22 & 23 & 25 & 26 & 27 & 28 & 29 & 30 & 31 \\
\hline$\alpha$ Ratio & 0.225 & 0.213 & 0.450 & 243.06 & 98958.4 & 4.706 & 0.968 & 33.433 & 33.438 & 0.001 & 1.79 \\
$\beta$ Ratio & 0.720 & 0.682 & 1.439 & 37.50 & 3643.5 & 7.568 & 0.720 & 5.410 & 5.410 & 0.000 & 194 \\
$\gamma$ Ratio & & & & & & & & & \\
\hline
\end{tabular}

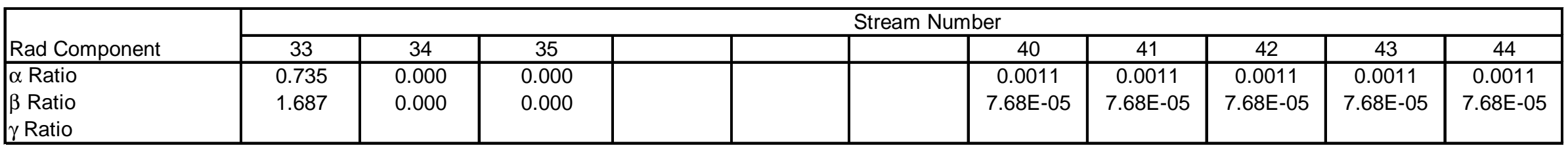

\section{Notes:}

1. Y-12 analysis of incoming SRS UNH in the 1982-1984 timeframe assumed for UNH and U metal feed streams for the duration of campaign

2. SRS data shows significantly less $\mathrm{Np}$ than $\mathrm{Y}-12$

3. INEEL analysis of Fernald DU metal assumed for composition of $Y-12$ stream 31 to S-3 Ponds

4. Sufficient DU added to stream 33 by way of stream 31 to yield observed U-235 content of S-3 sludge (i.e., $0.34 \%$ U-235)

5. Tc added to stream 33 by way of stream 32 to yield observed Tc sludge concentration in SE pond of $12,000 \mathrm{pCi} / \mathrm{g}$ wet wt

6. Th-228 not included in the calculation of $\alpha$ ratio

7. Assumed nominal specific activity of weapon grade HEU used in calculation of $\alpha$ ratio is $140 \mathrm{dpm} / \mu \mathrm{g}$

8. Assumed nominal specific activity of uranium sample enriched in U-235 with no TRU for $\beta$ ratio is based on Th-234, Pa-234, and Th-231 


\begin{tabular}{|c|c|c|c|c|c|}
\hline \multicolumn{6}{|l|}{ Chemical Forms of Uranium } \\
\hline Form $\quad$ Code & Form & Code & Form & Code & \\
\hline $\mathrm{U}$ (metal) & UO3 & 0.83 & UF6 & 0.68 & \\
\hline UO2 & UF4 & 0.76 & UO2F2 & 0.77 & \\
\hline U3O8 & UCl4 & 0.63 & UO2(NO3)2 & 0.6 & \\
\hline & $\%$ U-235 & U SpecAct uC & $/ g U$ & & \\
\hline U Enrichment $(\%$ U-235) = & 62.6 & $3.75 \mathrm{E}+01$ & Ratio & & \\
\hline & Code & DAC Value & Act to DAC & & \\
\hline Chemical Form of $U$ code $=$ & 0.6 & $6 \mathrm{E}-10$ & $6.25 \mathrm{E}+10$ & & \\
\hline SUM Constituent Act to $\mathrm{DAC}=$ & $4.19 \mathrm{E}+10$ & Fraction Dos & from Constit & uents & 0.6696 \\
\hline Constituent Data Units & uCi/g sample & $\mathrm{uCi} / \mathrm{g} U$ & DAC Value & Act to DAC & \\
\hline Pu-238 & & $0.00 \mathrm{E}+00$ & 3.00E-12 & $0.00 \mathrm{E}+00$ & \\
\hline Pu-239 & & $0.00 \mathrm{E}+00$ & $2.00 \mathrm{E}-12$ & $0.00 \mathrm{E}+00$ & \\
\hline Pu-240 & & $0.00 \mathrm{E}+00$ & $2.00 \mathrm{E}-12$ & $0.00 \mathrm{E}+00$ & \\
\hline Np-237 & & $0.00 \mathrm{E}+00$ & $2.00 \mathrm{E}-12$ & $0.00 \mathrm{E}+00$ & \\
\hline Am-241 & & $0.00 \mathrm{E}+00$ & $2.00 \mathrm{E}-12$ & $0.00 \mathrm{E}+00$ & \\
\hline U-236 & & $0.00 \mathrm{E}+00$ & $6.00 \mathrm{E}-10$ & $0.00 \mathrm{E}+00$ & \\
\hline Tc-99 & & $0.00 \mathrm{E}+00$ & $3.00 \mathrm{E}-07$ & $0.00 \mathrm{E}+00$ & \\
\hline & $\mathrm{uCi} / \mathrm{g} U$ & & DAC Value & Act to DAC & \\
\hline Pu-238 & 5.17E-03 & & 3.00E-12 & $1.72 \mathrm{E}+09$ & \\
\hline Pu-239 & $3.12 \mathrm{E}-06$ & & $2.00 \mathrm{E}-12$ & $1.56 \mathrm{E}+06$ & \\
\hline Pu-240 & $1.63 \mathrm{E}-06$ & & $2.00 \mathrm{E}-12$ & $8.17 \mathrm{E}+05$ & \\
\hline Np-237 & $2.03 \mathrm{E}-02$ & & $2.00 \mathrm{E}-12$ & $1.02 \mathrm{E}+10$ & \\
\hline Am-241 & $0.00 \mathrm{E}+00$ & & $2.00 \mathrm{E}-12$ & $0.00 \mathrm{E}+00$ & \\
\hline $\mathrm{U}-236$ & $1.80 \mathrm{E}+01$ & & $6.00 \mathrm{E}-10$ & $3.00 \mathrm{E}+10$ & \\
\hline Tc-99 & $1.39 \mathrm{E}+00$ & & $3.00 \mathrm{E}-07$ & $4.65 E+06$ & \\
\hline
\end{tabular}

\section{HEU Process Stream 5 (Y-12 \& SRS Data)}

Assume

Pu ppb $\quad 0.36$

Np ppb 28,800

Tc ppm 82

U-236 ppm 278,000

Assume U @ 62.5\% U-235

Assume Weapons Pu Dist

$\begin{array}{lr}\text { Pu-238 } & 84 \\ \text { Pu-239 } & 14 \\ \text { Pu-240 } & 2 \\ \text { Pu-241 } & 0 \\ \text { Pu-242 } & 0\end{array}$




\begin{tabular}{|c|c|c|c|c|c|}
\hline \multicolumn{6}{|l|}{ Chemical Forms of Uranium } \\
\hline Form $\quad$ Code & Form & Code & Form & Code & \\
\hline$\cup($ metal) & UO3 & 0.83 & UF6 & 0.68 & \\
\hline UO2 & UF4 & 0.76 & UO2F2 & 0.77 & \\
\hline U308 & $\mathrm{UCl} 4$ & 0.63 & UO2(NO3)2 & 0.6 & \\
\hline & $\%$ U-235 & U SpecAct uC & $\mathrm{i} / \mathrm{g} \mathrm{U}$ & & \\
\hline U Enrichment $(\%$ U-235) = & 62.6 & $3.75 E+01$ & Ratio & & \\
\hline & Code & DAC Value & Act to DAC & & \\
\hline Chemical Form of $U$ code $=$ & 0.6 & $6 \mathrm{E}-10$ & $6.25 \mathrm{E}+10$ & & \\
\hline SUM Constituent Act to $\mathrm{DAC}=$ & $1.04 \mathrm{E}+12$ & Fraction Dos & e from Constit & uents $=$ & 16.5699 \\
\hline Constituent Data Units & uCi/g sample & uCi/g U & DAC Value & Act to DAC & \\
\hline Pu-238 & & $0.00 \mathrm{E}+00$ & 3.00E-12 & $0.00 \mathrm{E}+00$ & \\
\hline Pu-239 & & $0.00 \mathrm{E}+00$ & $2.00 \mathrm{E}-12$ & $0.00 \mathrm{E}+00$ & \\
\hline Pu-240 & & $0.00 \mathrm{E}+00$ & $2.00 \mathrm{E}-12$ & $0.00 \mathrm{E}+00$ & \\
\hline Np-237 & & $0.00 \mathrm{E}+00$ & $2.00 \mathrm{E}-12$ & $0.00 \mathrm{E}+00$ & \\
\hline Am-241 & & $0.00 \mathrm{E}+00$ & $2.00 \mathrm{E}-12$ & $0.00 \mathrm{E}+00$ & \\
\hline U-236 & & $0.00 \mathrm{E}+00$ & $6.00 \mathrm{E}-10$ & $0.00 \mathrm{E}+00$ & \\
\hline Tc-99 & & $0.00 E+00$ & $3.00 \mathrm{E}-07$ & $0.00 \mathrm{E}+00$ & \\
\hline & $\mathrm{uCi} / \mathrm{g} U$ & & DAC Value & Act to DAC & \\
\hline Pu-238 & $5.21 \mathrm{E}-01$ & & 3.00E-12 & $1.74 \mathrm{E}+11$ & \\
\hline Pu-239 & $3.15 \mathrm{E}-04$ & & $2.00 \mathrm{E}-12$ & $1.58 \mathrm{E}+08$ & \\
\hline Pu-240 & $1.65 \mathrm{E}-04$ & & $2.00 \mathrm{E}-12$ & $8.24 \mathrm{E}+07$ & \\
\hline Np-237 & $1.66 \mathrm{E}+00$ & & $2.00 \mathrm{E}-12$ & $8.32 \mathrm{E}+11$ & \\
\hline Am-241 & $0.00 \mathrm{E}+00$ & & $2.00 \mathrm{E}-12$ & $0.00 \mathrm{E}+00$ & \\
\hline$U-236$ & $1.80 \mathrm{E}+01$ & & $6.00 \mathrm{E}-10$ & $3.00 \mathrm{E}+10$ & \\
\hline Tc-99 & $7.55 \mathrm{E}+00$ & & $3.00 \mathrm{E}-07$ & $2.52 E+07$ & \\
\hline
\end{tabular}

9212 HEU Process Stream 11 (Y-12 \& SRS Data)

Assume

Pu ppb

36.3

Np ppb 2,360,000

Tc ppm $\quad 444$

U-236 ppm 278,000

Assume U @ 62.5\% U-235

Assume Weapons Pu Dist

$\begin{array}{lr}\text { Pu-238 } & 84 \\ \text { Pu-239 } & 14 \\ \text { Pu-240 } & 2 \\ \text { Pu-241 } & 0 \\ \text { Pu-242 } & 0\end{array}$




\begin{tabular}{|c|c|c|c|c|c|}
\hline \multicolumn{6}{|l|}{ Chemical Forms of Uranium } \\
\hline Form $\quad$ Code & Form & Code & Form & Code & \\
\hline $\mathrm{U}$ (metal) & UO3 & 0.83 & UF6 & 0.68 & \\
\hline UO2 & UF4 & 0.76 & UO2F2 & 0.77 & \\
\hline U308 & $\mathrm{UCl} 4$ & 0.63 & UO2(NO3)2 & 0.6 & \\
\hline & $\%$ U-235 & U SpecAct uC & $\mathrm{i} / \mathrm{g} \mathrm{U}$ & & \\
\hline U Enrichment $(\%$ U-235) = & 62.6 & $3.75 E+01$ & Ratio & & \\
\hline & Code & DAC Value & Act to DAC & & \\
\hline Chemical Form of $U$ code $=$ & 0.6 & $6 \mathrm{E}-10$ & $6.25 \mathrm{E}+10$ & & \\
\hline SUM Constituent Act to $\mathrm{DAC}=$ & $1.74 \mathrm{E}+11$ & Fraction Dos & e from Constit & uents $=$ & 2.7756 \\
\hline Constituent Data Units & uCi/g sample & uCi/g U & DAC Value & Act to DAC & \\
\hline Pu-238 & & $0.00 \mathrm{E}+00$ & 3.00E-12 & $0.00 \mathrm{E}+00$ & \\
\hline Pu-239 & & $0.00 \mathrm{E}+00$ & $2.00 \mathrm{E}-12$ & $0.00 \mathrm{E}+00$ & \\
\hline Pu-240 & & $0.00 \mathrm{E}+00$ & $2.00 \mathrm{E}-12$ & $0.00 \mathrm{E}+00$ & \\
\hline Np-237 & & $0.00 \mathrm{E}+00$ & $2.00 \mathrm{E}-12$ & $0.00 \mathrm{E}+00$ & \\
\hline Am-241 & & $0.00 \mathrm{E}+00$ & $2.00 \mathrm{E}-12$ & $0.00 \mathrm{E}+00$ & \\
\hline U-236 & & $0.00 \mathrm{E}+00$ & $6.00 \mathrm{E}-10$ & $0.00 \mathrm{E}+00$ & \\
\hline Tc-99 & & $0.00 E+00$ & $3.00 \mathrm{E}-07$ & $0.00 \mathrm{E}+00$ & \\
\hline & $\mathrm{uCi} / \mathrm{g} U$ & & DAC Value & Act to DAC & \\
\hline Pu-238 & $6.46 \mathrm{E}-02$ & & 3.00E-12 & $2.15 \mathrm{E}+10$ & \\
\hline Pu-239 & $3.91 \mathrm{E}-05$ & & $2.00 \mathrm{E}-12$ & $1.95 \mathrm{E}+07$ & \\
\hline Pu-240 & $2.04 \mathrm{E}-05$ & & $2.00 \mathrm{E}-12$ & $1.02 \mathrm{E}+07$ & \\
\hline Np-237 & $2.44 \mathrm{E}-01$ & & $2.00 \mathrm{E}-12$ & $1.22 \mathrm{E}+11$ & \\
\hline Am-241 & $0.00 \mathrm{E}+00$ & & $2.00 \mathrm{E}-12$ & $0.00 \mathrm{E}+00$ & \\
\hline$U-236$ & $1.80 \mathrm{E}+01$ & & $6.00 \mathrm{E}-10$ & $3.00 \mathrm{E}+10$ & \\
\hline Tc-99 & $3.59 \mathrm{E}+00$ & & $3.00 \mathrm{E}-07$ & $1.20 \mathrm{E}+07$ & \\
\hline
\end{tabular}

9212 HEU Process Stream 14 (Y-12 \& SRS Data)

Assume

Pu ppb $\quad 4.5$

Np ppb 346,000

Tc ppm $\quad 211$

U-236 ppm 278,000

Assume U @ 62.5\% U-235

Assume Weapons Pu Dist

$\begin{array}{lr}\text { Pu-238 } & 84 \\ \text { Pu-239 } & 14 \\ \text { Pu-240 } & 2 \\ \text { Pu-241 } & 0 \\ \text { Pu-242 } & 0\end{array}$




\begin{tabular}{|c|c|c|c|c|c|}
\hline \multicolumn{6}{|l|}{ Chemical Forms of Uranium } \\
\hline Form $\quad$ Code & Form & Code & Form & Code & \\
\hline $\mathrm{U}$ (metal) & UO3 & 0.83 & UF6 & 0.68 & \\
\hline UO2 & UF4 & 0.76 & UO2F2 & 0.77 & \\
\hline U308 & $\mathrm{UCl} 4$ & 0.63 & UO2(NO3)2 & 0.6 & \\
\hline & $\%$ U-235 & U SpecAct uC & $\mathrm{i} / \mathrm{g} \mathrm{U}$ & & \\
\hline U Enrichment $(\%$ U-235) = & 62.6 & $3.75 E+01$ & Ratio & & \\
\hline & Code & DAC Value & Act to DAC & & \\
\hline Chemical Form of $U$ code $=$ & 0.83 & $3 E-10$ & $1.25 \mathrm{E}+11$ & & \\
\hline SUM Constituent Act to $\mathrm{DAC}=$ & $6.95 \mathrm{E}+10$ & Fraction Dos & e from Constit & tuents & 0.5558 \\
\hline Constituent Data Units & uCi/g sample & uCi/g U & DAC Value & Act to DAC & \\
\hline Pu-238 & & $0.00 \mathrm{E}+00$ & 3.00E-12 & $0.00 \mathrm{E}+00$ & \\
\hline Pu-239 & & $0.00 \mathrm{E}+00$ & $2.00 \mathrm{E}-12$ & $0.00 \mathrm{E}+00$ & \\
\hline Pu-240 & & $0.00 \mathrm{E}+00$ & $2.00 \mathrm{E}-12$ & $0.00 \mathrm{E}+00$ & \\
\hline Np-237 & & $0.00 \mathrm{E}+00$ & $2.00 \mathrm{E}-12$ & $0.00 \mathrm{E}+00$ & \\
\hline Am-241 & & $0.00 \mathrm{E}+00$ & $2.00 \mathrm{E}-12$ & $0.00 \mathrm{E}+00$ & \\
\hline U-236 & & $0.00 \mathrm{E}+00$ & $3.00 \mathrm{E}-10$ & $0.00 \mathrm{E}+00$ & \\
\hline Tc-99 & & $0.00 E+00$ & $3.00 \mathrm{E}-07$ & $0.00 \mathrm{E}+00$ & \\
\hline & $\mathrm{uCi} / \mathrm{g} U$ & & DAC Value & Act to DAC & \\
\hline Pu-238 & $3.45 \mathrm{E}-03$ & & 3.00E-12 & $1.15 \mathrm{E}+09$ & \\
\hline Pu-239 & $2.08 \mathrm{E}-06$ & & $2.00 \mathrm{E}-12$ & $1.04 \mathrm{E}+06$ & \\
\hline Pu-240 & $1.09 \mathrm{E}-06$ & & $2.00 \mathrm{E}-12$ & $5.45 \mathrm{E}+05$ & \\
\hline Np-237 & $1.68 \mathrm{E}-02$ & & $2.00 \mathrm{E}-12$ & $8.39 E+09$ & \\
\hline Am-241 & $0.00 \mathrm{E}+00$ & & $2.00 \mathrm{E}-12$ & $0.00 \mathrm{E}+00$ & \\
\hline U-236 & $1.80 \mathrm{E}+01$ & & $3.00 \mathrm{E}-10$ & $6.00 \mathrm{E}+10$ & \\
\hline Tc-99 & $1.45 \mathrm{E}+00$ & & $3.00 \mathrm{E}-07$ & $4.82 \mathrm{E}+06$ & \\
\hline
\end{tabular}

9212 HEU Process Stream 19 (Y-12 \& SRS Data)

Assume

Pu ppb $\quad 0.24$

Np ppb 23,800

Tc ppm $\quad 85$

U-236 ppm 278,000

Assume U @ 62.5\% U-235

Assume Weapons Pu Dist

$\begin{array}{lr}\text { Pu-238 } & 84 \\ \text { Pu-239 } & 14 \\ \text { Pu-240 } & 2 \\ \text { Pu-241 } & 0 \\ \text { Pu-242 } & 0\end{array}$




\begin{tabular}{|c|c|c|c|c|c|}
\hline \multicolumn{6}{|l|}{ Chemical Forms of Uranium } \\
\hline Form $\quad$ Code & Form & Code & Form & Code & \\
\hline $\mathrm{U}$ (metal) & UO3 & 0.83 & UF6 & 0.68 & \\
\hline UO2 & UF4 & 0.76 & UO2F2 & 0.77 & \\
\hline U308 & $\mathrm{UCl} 4$ & 0.63 & UO2(NO3)2 & 0.6 & \\
\hline & $\%$ U-235 & U SpecAct uC & $\mathrm{i} / \mathrm{g} \mathrm{U}$ & & \\
\hline U Enrichment $(\%$ U-235) = & 62.6 & $3.75 E+01$ & Ratio & & \\
\hline & Code & DAC Value & Act to DAC & & \\
\hline Chemical Form of $U$ code $=$ & 1 & $3 E-10$ & $1.25 \mathrm{E}+11$ & & \\
\hline SUM Constituent Act to $\mathrm{DAC}=$ & $6.95 \mathrm{E}+10$ & Fraction Dos & e from Constit & tuents & 0.5555 \\
\hline Constituent Data Units & uCi/g sample & uCi/g U & DAC Value & Act to DAC & \\
\hline Pu-238 & & $0.00 \mathrm{E}+00$ & 3.00E-12 & $0.00 \mathrm{E}+00$ & \\
\hline Pu-239 & & $0.00 \mathrm{E}+00$ & $2.00 \mathrm{E}-12$ & $0.00 \mathrm{E}+00$ & \\
\hline Pu-240 & & $0.00 \mathrm{E}+00$ & $2.00 \mathrm{E}-12$ & $0.00 \mathrm{E}+00$ & \\
\hline Np-237 & & $0.00 \mathrm{E}+00$ & $2.00 \mathrm{E}-12$ & $0.00 \mathrm{E}+00$ & \\
\hline Am-241 & & $0.00 \mathrm{E}+00$ & $2.00 \mathrm{E}-12$ & $0.00 \mathrm{E}+00$ & \\
\hline U-236 & & $0.00 \mathrm{E}+00$ & $3.00 \mathrm{E}-10$ & $0.00 \mathrm{E}+00$ & \\
\hline Tc-99 & & $0.00 E+00$ & $3.00 \mathrm{E}-07$ & $0.00 \mathrm{E}+00$ & \\
\hline & $\mathrm{uCi} / \mathrm{g} U$ & & DAC Value & Act to DAC & \\
\hline Pu-238 & $3.45 \mathrm{E}-03$ & & 3.00E-12 & $1.15 \mathrm{E}+09$ & \\
\hline Pu-239 & $2.08 \mathrm{E}-06$ & & $2.00 \mathrm{E}-12$ & $1.04 \mathrm{E}+06$ & \\
\hline Pu-240 & $1.09 \mathrm{E}-06$ & & $2.00 \mathrm{E}-12$ & $5.45 \mathrm{E}+05$ & \\
\hline Np-237 & $1.67 \mathrm{E}-02$ & & $2.00 \mathrm{E}-12$ & $8.35 \mathrm{E}+09$ & \\
\hline Am-241 & $0.00 \mathrm{E}+00$ & & $2.00 \mathrm{E}-12$ & $0.00 \mathrm{E}+00$ & \\
\hline U-236 & $1.80 \mathrm{E}+01$ & & $3.00 \mathrm{E}-10$ & $6.00 \mathrm{E}+10$ & \\
\hline Tc-99 & $1.45 \mathrm{E}+00$ & & $3.00 \mathrm{E}-07$ & $4.82 \mathrm{E}+06$ & \\
\hline
\end{tabular}

9212 HEU Process Stream 22 (Y-12 \& SRS Data)

Assume

Pu ppb $\quad 0.24$

Np ppb 23,700

Tc ppm 85

U-236 ppm 278,000

Assume U @ 62.5\% U-235

Assume Weapons Pu Dist

$\begin{array}{lr}\text { Pu-238 } & 84 \\ \text { Pu-239 } & 14 \\ \text { Pu-240 } & 2 \\ \text { Pu-241 } & 0 \\ \text { Pu-242 } & 0\end{array}$




\begin{tabular}{|c|c|c|c|c|c|}
\hline \\
\hline \multicolumn{6}{|l|}{ Chemical Forms of Uranium } \\
\hline $\mathrm{U}$ (metal) & UO3 & 0.83 & UF6 & 0.68 & \\
\hline UO2 & UF4 & 0.76 & UO2F2 & 0.77 & \\
\hline U308 & $\mathrm{UCl} 4$ & 0.63 & UO2(NO3)2 & 0.6 & \\
\hline \multirow{3}{*}{ U Enrichment $(\%$ U-235) = } & $\%$ U-235 & \multicolumn{4}{|c|}{ U SpecAct uCi/g U } \\
\hline & 62.6 & $3.75 E+01$ & Ratio & & \\
\hline & Code & DAC Value & Act to DAC & & \\
\hline Chemical Form of $U$ code $=$ & 0.88 & $3 \mathrm{E}-10$ & $1.25 \mathrm{E}+11$ & & \\
\hline SUM Constituent Act to $\mathrm{DAC}=$ & $7.90 \mathrm{E}+10$ & \multicolumn{3}{|c|}{ Fraction Dose from Constituents $=$} & 0.6319 \\
\hline \multirow{8}{*}{\begin{tabular}{|c} 
Constituent Data Units \\
Pu-238 \\
Pu-239 \\
Pu-240 \\
Np-237 \\
Am-241 \\
U-236 \\
Tc-99
\end{tabular}} & uCi/g sample & uCi/g U & DAC Value & \multicolumn{2}{|l|}{ Act to DAC } \\
\hline & & $0.00 \mathrm{E}+00$ & 3.00E-12 & \multicolumn{2}{|l|}{$0.00 \mathrm{E}+00$} \\
\hline & & $0.00 \mathrm{E}+00$ & $2.00 \mathrm{E}-12$ & \multirow{2}{*}{\multicolumn{2}{|c|}{$\begin{array}{l}0.00 E+00 \\
0.00 E+00\end{array}$}} \\
\hline & & $0.00 \mathrm{E}+00$ & $2.00 \mathrm{E}-12$ & & \\
\hline & & $0.00 \mathrm{E}+00$ & $2.00 \mathrm{E}-12$ & \multicolumn{2}{|l|}{$0.00 \mathrm{E}+00$} \\
\hline & & $0.00 \mathrm{E}+00$ & $2.00 \mathrm{E}-12$ & \multicolumn{2}{|l|}{$0.00 \mathrm{E}+00$} \\
\hline & & $0.00 \mathrm{E}+00$ & $3.00 \mathrm{E}-10$ & \multicolumn{2}{|l|}{$0.00 \mathrm{E}+00$} \\
\hline & & $0.00 E+00$ & $3.00 \mathrm{E}-07$ & \multicolumn{2}{|l|}{$0.00 \mathrm{E}+00$} \\
\hline & $\mathrm{uCi} / \mathrm{g} U$ & & DAC Value & \multicolumn{2}{|l|}{ Act to DAC } \\
\hline Pu-238 & $7.01 \mathrm{E}-03$ & & 3.00E-12 & \multicolumn{2}{|l|}{$2.34 \mathrm{E}+09$} \\
\hline Pu-239 & $4.24 \mathrm{E}-06$ & & $2.00 \mathrm{E}-12$ & \multicolumn{2}{|l|}{$2.12 \mathrm{E}+06$} \\
\hline Pu-240 & $2.22 \mathrm{E}-06$ & & $2.00 \mathrm{E}-12$ & \multicolumn{2}{|l|}{$1.11 \mathrm{E}+06$} \\
\hline $\mathrm{Np}-237$ & $3.34 \mathrm{E}-02$ & & $2.00 \mathrm{E}-12$ & \\
\hline \multirow{3}{*}{$\begin{array}{c}\text { Am-241 } \\
\text { U-236 } \\
\text { Tc-99 }\end{array}$} & $0.00 \mathrm{E}+00$ & & $2.00 \mathrm{E}-12$ & \multicolumn{2}{|l|}{$0.00 \mathrm{E}+00$} \\
\hline & $1.80 \mathrm{E}+01$ & & $3.00 \mathrm{E}-10$ & \multirow{2}{*}{\multicolumn{2}{|c|}{$\begin{array}{l}6.00 \mathrm{E}+10 \\
9.63 \mathrm{E}+06\end{array}$}} \\
\hline & $2.89 \mathrm{E}+00$ & & $3.00 \mathrm{E}-07$ & & \\
\hline
\end{tabular}

9212 HEU Process Stream 23 (Y-12 \& SRS Data)

Assume

Pu ppb $\quad 0.488$

$\mathrm{Np} \mathrm{ppb} \quad 47,400$

Tc ppm $\quad 170$

U-236 ppm 278,000

Assume U @ 62.5\% U-235

Assume Weapons Pu Dist

$\begin{array}{lr}\text { Pu-238 } & 84 \\ \text { Pu-239 } & 14 \\ \text { Pu-240 } & 2 \\ \text { Pu-241 } & 0 \\ \text { Pu-242 } & 0\end{array}$




\begin{tabular}{|c|c|c|c|c|c|}
\hline \multicolumn{6}{|l|}{ Chemical Forms of Uranium } \\
\hline Form $\quad$ Code & Form & Code & Form & Code & \\
\hline$\cup($ metal) & UO3 & 0.83 & UF6 & 0.68 & \\
\hline UO2 & UF4 & 0.76 & UO2F2 & 0.77 & \\
\hline U308 & $\mathrm{UCl} 4$ & 0.63 & UO2(NO3)2 & 0.6 & \\
\hline & $\%$ U-235 & U SpecAct uC & $\mathrm{i} / \mathrm{g} \mathrm{U}$ & & \\
\hline U Enrichment $(\%$ U-235) = & 62.6 & $3.75 E+01$ & Ratio & & \\
\hline & Code & DAC Value & Act to DAC & & \\
\hline Chemical Form of $U$ code $=$ & 0.6 & $6 \mathrm{E}-10$ & $6.25 \mathrm{E}+10$ & & \\
\hline SUM Constituent Act to $\mathrm{DAC}=$ & $1.01 \mathrm{E}+13$ & Fraction Dos & e from Constit & uents $=$ & 161.3840 \\
\hline Constituent Data Units & uCi/g sample & uCi/g U & DAC Value & Act to DAC & \\
\hline Pu-238 & & $0.00 \mathrm{E}+00$ & 3.00E-12 & $0.00 \mathrm{E}+00$ & \\
\hline Pu-239 & & $0.00 \mathrm{E}+00$ & $2.00 \mathrm{E}-12$ & $0.00 \mathrm{E}+00$ & \\
\hline Pu-240 & & $0.00 \mathrm{E}+00$ & $2.00 \mathrm{E}-12$ & $0.00 \mathrm{E}+00$ & \\
\hline Np-237 & & $0.00 \mathrm{E}+00$ & $2.00 \mathrm{E}-12$ & $0.00 \mathrm{E}+00$ & \\
\hline Am-241 & & $0.00 \mathrm{E}+00$ & $2.00 \mathrm{E}-12$ & $0.00 \mathrm{E}+00$ & \\
\hline U-236 & & $0.00 \mathrm{E}+00$ & $6.00 \mathrm{E}-10$ & $0.00 \mathrm{E}+00$ & \\
\hline Tc-99 & & $0.00 E+00$ & $3.00 \mathrm{E}-07$ & $0.00 \mathrm{E}+00$ & \\
\hline & $\mathrm{uCi} / \mathrm{g} U$ & & DAC Value & Act to DAC & \\
\hline Pu-238 & $5.21 \mathrm{E}+00$ & & 3.00E-12 & $1.74 \mathrm{E}+12$ & \\
\hline Pu-239 & $3.15 \mathrm{E}-03$ & & $2.00 \mathrm{E}-12$ & $1.58 \mathrm{E}+09$ & \\
\hline Pu-240 & $1.65 \mathrm{E}-03$ & & $2.00 \mathrm{E}-12$ & $8.24 \mathrm{E}+08$ & \\
\hline Np-237 & $1.66 \mathrm{E}+01$ & & $2.00 \mathrm{E}-12$ & $8.32 \mathrm{E}+12$ & \\
\hline Am-241 & $0.00 \mathrm{E}+00$ & & $2.00 \mathrm{E}-12$ & $0.00 \mathrm{E}+00$ & \\
\hline$U-236$ & $1.80 \mathrm{E}+01$ & & $6.00 \mathrm{E}-10$ & $3.00 \mathrm{E}+10$ & \\
\hline Tc-99 & $7.55 \mathrm{E}+01$ & & $3.00 \mathrm{E}-07$ & $2.52 E+08$ & \\
\hline
\end{tabular}

9212 HEU Process Stream 25 (Y-12 \& SRS Data)

Assume

$\begin{array}{rr}\text { Pu ppb } & 363 \\ \text { Np ppb } & 23,600,000 \\ \text { Tc ppm } & 4,440 \\ 236 \text { ppm } & 278,000\end{array}$

Assume U @ 62.5\% U-235

Assume Weapons Pu Dist

$\begin{array}{lr}\text { Pu-238 } & 84 \\ \text { Pu-239 } & 14 \\ \text { Pu-240 } & 2 \\ \text { Pu-241 } & 0 \\ \text { Pu-242 } & 0\end{array}$




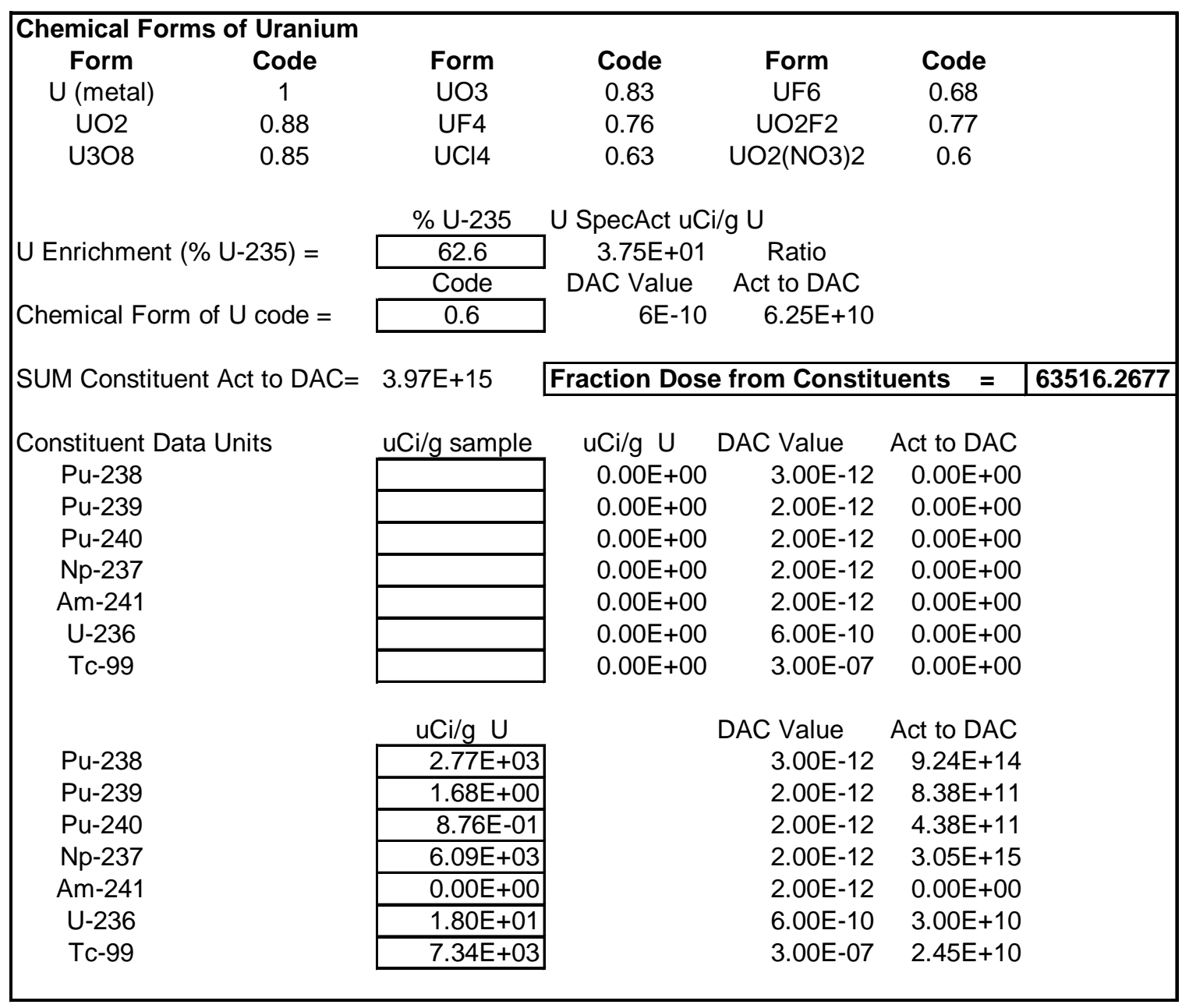

9212 HEU Process Stream 26 (Y-12 \& SRS Data)

Assume

Pu ppb 193,000

Np ppb 8,640,000,000

Tc ppm 432,000

U-236 ppm 278,000

Assume U @ 62.5\% U-235

Assume Weapons Pu Dist

$\begin{array}{lr}\text { Pu-238 } & 84 \\ \text { Pu-239 } & 14 \\ \text { Pu-240 } & 2 \\ \text { Pu-241 } & 0 \\ \text { Pu-242 } & 0\end{array}$




\begin{tabular}{|c|c|c|c|c|c|}
\hline \multicolumn{6}{|l|}{ Chemical Forms of Uranium } \\
\hline Form $\quad$ Code & Form & Code & Form & Code & \\
\hline $\mathrm{U}$ (metal) & UO3 & 0.83 & UF6 & 0.68 & \\
\hline UO2 & UF4 & 0.76 & UO2F2 & 0.77 & \\
\hline U308 & $\mathrm{UCl} 4$ & 0.63 & UO2(NO3)2 & 0.6 & \\
\hline & $\%$ U-235 & U SpecAct uCi & $\mathrm{i} / \mathrm{g} \mathrm{U}$ & & \\
\hline U Enrichment $(\%$ U-235) = & 62.6 & $3.75 \mathrm{E}+01$ & Ratio & & \\
\hline & Code & DAC Value & Act to DAC & & \\
\hline Chemical Form of $U$ code $=$ & 0.6 & $6 \mathrm{E}-10$ & $6.25 \mathrm{E}+10$ & & \\
\hline SUM Constituent Act to $\mathrm{DAC}=$ & $2.27 \mathrm{E}+11$ & Fraction Dose & e from Constit & uents $=$ & 3.6319 \\
\hline Constituent Data Units & uCi/g sample & uCi/g U & DAC Value & Act to DAC & \\
\hline Pu-238 & & $0.00 \mathrm{E}+00$ & 3.00E-12 & $0.00 \mathrm{E}+00$ & \\
\hline Pu-239 & & $0.00 \mathrm{E}+00$ & $2.00 \mathrm{E}-12$ & $0.00 \mathrm{E}+00$ & \\
\hline Pu-240 & & $0.00 \mathrm{E}+00$ & $2.00 \mathrm{E}-12$ & $0.00 \mathrm{E}+00$ & \\
\hline Np-237 & & $0.00 \mathrm{E}+00$ & $2.00 \mathrm{E}-12$ & $0.00 \mathrm{E}+00$ & \\
\hline Am-241 & & $0.00 \mathrm{E}+00$ & $2.00 \mathrm{E}-12$ & $0.00 \mathrm{E}+00$ & \\
\hline U-236 & & $0.00 \mathrm{E}+00$ & $6.00 \mathrm{E}-10$ & $0.00 \mathrm{E}+00$ & \\
\hline Tc-99 & & $0.00 \mathrm{E}+00$ & $3.00 \mathrm{E}-07$ & $0.00 \mathrm{E}+00$ & \\
\hline & $\mathrm{uCi} / \mathrm{g} U$ & & DAC Value & Act to DAC & \\
\hline Pu-238 & $8.76 \mathrm{E}-02$ & & 3.00E-12 & $2.92 \mathrm{E}+10$ & \\
\hline Pu-239 & $5.29 \mathrm{E}-05$ & & $2.00 \mathrm{E}-12$ & $2.65 \mathrm{E}+07$ & \\
\hline Pu-240 & $2.77 \mathrm{E}-05$ & & $2.00 \mathrm{E}-12$ & $1.38 \mathrm{E}+07$ & \\
\hline Np-237 & $3.36 \mathrm{E}-01$ & & $2.00 \mathrm{E}-12$ & $1.68 \mathrm{E}+11$ & \\
\hline Am-241 & $0.00 \mathrm{E}+00$ & & $2.00 \mathrm{E}-12$ & $0.00 \mathrm{E}+00$ & \\
\hline$U-236$ & $1.80 \mathrm{E}+01$ & & $6.00 \mathrm{E}-10$ & $3.00 \mathrm{E}+10$ & \\
\hline Tc-99 & $1.52 \mathrm{E}+01$ & & $3.00 \mathrm{E}-07$ & $5.08 \mathrm{E}+07$ & \\
\hline
\end{tabular}

9212 HEU Process Stream 27 (Y-12 \& SRS Data)

Assume

Pu ppb $\quad 6.1$

Np ppb $\quad 476,000$

Tc ppm $\quad 896$

U-236 ppm 278,000

Assume U @ 62.5\% U-235

Assume Weapons Pu Dist

$\begin{array}{lr}\text { Pu-238 } & 84 \\ \text { Pu-239 } & 14 \\ \text { Pu-240 } & 2 \\ \text { Pu-241 } & 0 \\ \text { Pu-242 } & 0\end{array}$




\begin{tabular}{|c|c|c|c|c|c|}
\hline \multicolumn{6}{|l|}{ Chemical Forms of Uranium } \\
\hline Form $\quad$ Code & Form & Code & Form & Code & \\
\hline$\cup($ metal) & UO3 & 0.83 & UF6 & 0.68 & \\
\hline UO2 & UF4 & 0.76 & UO2F2 & 0.77 & \\
\hline U308 & $\mathrm{UCl} 4$ & 0.63 & UO2(NO3)2 & 0.6 & \\
\hline & $\%$ U-235 & U SpecAct uC & $\mathrm{i} / \mathrm{g} \mathrm{U}$ & & \\
\hline U Enrichment $(\%$ U-235) = & 62.6 & $3.75 E+01$ & Ratio & & \\
\hline & Code & DAC Value & Act to DAC & & \\
\hline Chemical Form of $U$ code $=$ & 0.6 & $6 \mathrm{E}-10$ & $6.25 \mathrm{E}+10$ & & \\
\hline SUM Constituent Act to $\mathrm{DAC}=$ & $1.38 \mathrm{E}+12$ & Fraction Dos & e from Constit & tuents & 22.0674 \\
\hline Constituent Data Units & uCi/g sample & uCi/g U & DAC Value & Act to DAC & \\
\hline Pu-238 & & $0.00 \mathrm{E}+00$ & 3.00E-12 & $0.00 \mathrm{E}+00$ & \\
\hline Pu-239 & & $0.00 \mathrm{E}+00$ & $2.00 \mathrm{E}-12$ & $0.00 \mathrm{E}+00$ & \\
\hline Pu-240 & & $0.00 \mathrm{E}+00$ & $2.00 \mathrm{E}-12$ & $0.00 \mathrm{E}+00$ & \\
\hline Np-237 & & $0.00 \mathrm{E}+00$ & $2.00 \mathrm{E}-12$ & $0.00 \mathrm{E}+00$ & \\
\hline Am-241 & & $0.00 \mathrm{E}+00$ & $2.00 \mathrm{E}-12$ & $0.00 \mathrm{E}+00$ & \\
\hline U-236 & & $0.00 \mathrm{E}+00$ & $6.00 \mathrm{E}-10$ & $0.00 \mathrm{E}+00$ & \\
\hline Tc-99 & & $0.00 E+00$ & $3.00 \mathrm{E}-07$ & $0.00 \mathrm{E}+00$ & \\
\hline & $\mathrm{uCi} / \mathrm{g} U$ & & DAC Value & Act to DAC & \\
\hline Pu-238 & $8.96 \mathrm{E}-01$ & & 3.00E-12 & $2.99 \mathrm{E}+11$ & \\
\hline Pu-239 & $5.42 \mathrm{E}-04$ & & $2.00 \mathrm{E}-12$ & $2.71 \mathrm{E}+08$ & \\
\hline Pu-240 & $2.83 \mathrm{E}-04$ & & $2.00 \mathrm{E}-12$ & $1.42 \mathrm{E}+08$ & \\
\hline Np-237 & $2.10 \mathrm{E}+00$ & & $2.00 \mathrm{E}-12$ & $1.05 \mathrm{E}+12$ & \\
\hline Am-241 & $0.00 \mathrm{E}+00$ & & $2.00 \mathrm{E}-12$ & $0.00 \mathrm{E}+00$ & \\
\hline$U-236$ & $1.80 \mathrm{E}+01$ & & $6.00 \mathrm{E}-10$ & $3.00 \mathrm{E}+10$ & \\
\hline Tc-99 & $1.09 \mathrm{E}+01$ & & $3.00 \mathrm{E}-07$ & $3.63 E+07$ & \\
\hline
\end{tabular}

9212 HEU Process Stream 30 (Y-12 \& SRS Data)

Assume

Pu ppb $\quad 62.4$

Np ppb 2,980,000

Tc ppm $\quad 641$

U-236 ppm 278,000

Assume U @ 62.5\% U-235

Assume Weapons Pu Dist

$\begin{array}{lr}\text { Pu-238 } & 84 \\ \text { Pu-239 } & 14 \\ \text { Pu-240 } & 2 \\ \text { Pu-241 } & 0 \\ \text { Pu-242 } & 0\end{array}$




\begin{tabular}{|c|c|c|c|c|c|}
\hline \multicolumn{6}{|l|}{ Chemical Forms of Uranium } \\
\hline Form $\quad$ Code & Form & Code & Form & Code & \\
\hline $\mathrm{U}$ (metal) & UO3 & 0.83 & UF6 & 0.68 & \\
\hline UO2 & UF4 & 0.76 & UO2F2 & 0.77 & \\
\hline U308 & $\mathrm{UCl} 4$ & 0.63 & UO2(NO3)2 & 0.6 & \\
\hline & $\%$ U-235 & U SpecAct uC & $\mathrm{i} / \mathrm{g} \mathrm{U}$ & & \\
\hline U Enrichment $(\%$ U-235) = & 62.6 & $3.75 E+01$ & Ratio & & \\
\hline & Code & DAC Value & Act to DAC & & \\
\hline Chemical Form of $U$ code $=$ & 0.6 & $6 \mathrm{E}-10$ & $6.25 \mathrm{E}+10$ & & \\
\hline SUM Constituent Act to $\mathrm{DAC}=$ & $3.29 \mathrm{E}+10$ & Fraction Dos & e from Constit & tuents & 0.5270 \\
\hline Constituent Data Units & uCi/g sample & uCi/g U & DAC Value & Act to DAC & \\
\hline Pu-238 & & $0.00 \mathrm{E}+00$ & 3.00E-12 & $0.00 \mathrm{E}+00$ & \\
\hline Pu-239 & & $0.00 \mathrm{E}+00$ & $2.00 \mathrm{E}-12$ & $0.00 \mathrm{E}+00$ & \\
\hline Pu-240 & & $0.00 \mathrm{E}+00$ & $2.00 \mathrm{E}-12$ & $0.00 \mathrm{E}+00$ & \\
\hline Np-237 & & $0.00 \mathrm{E}+00$ & $2.00 \mathrm{E}-12$ & $0.00 \mathrm{E}+00$ & \\
\hline Am-241 & & $0.00 \mathrm{E}+00$ & $2.00 \mathrm{E}-12$ & $0.00 \mathrm{E}+00$ & \\
\hline U-236 & & $0.00 \mathrm{E}+00$ & $6.00 \mathrm{E}-10$ & $0.00 \mathrm{E}+00$ & \\
\hline Tc-99 & & $0.00 E+00$ & $3.00 \mathrm{E}-07$ & $0.00 \mathrm{E}+00$ & \\
\hline & $\mathrm{uCi} / \mathrm{g} U$ & & DAC Value & Act to DAC & \\
\hline Pu-238 & 1.94E-02 & & 3.00E-12 & $6.46 \mathrm{E}+09$ & \\
\hline Pu-239 & 1.17E-05 & & $2.00 \mathrm{E}-12$ & $5.86 \mathrm{E}+06$ & \\
\hline Pu-240 & $6.13 \mathrm{E}-06$ & & $2.00 \mathrm{E}-12$ & $3.06 \mathrm{E}+06$ & \\
\hline Np-237 & $4.65 \mathrm{E}-02$ & & $2.00 \mathrm{E}-12$ & $2.32 \mathrm{E}+10$ & \\
\hline Am-241 & $0.00 \mathrm{E}+00$ & & $2.00 \mathrm{E}-12$ & $0.00 \mathrm{E}+00$ & \\
\hline$U-236$ & $1.94 \mathrm{E}+00$ & & $6.00 \mathrm{E}-10$ & $3.24 \mathrm{E}+09$ & \\
\hline Tc-99 & $3.40 \mathrm{E}+00$ & & $3.00 \mathrm{E}-07$ & $1.13 \mathrm{E}+07$ & \\
\hline
\end{tabular}

9212 HEU Process Stream 33 (Y-12 \& SRS Data)

Assume

Pu ppb $\quad 1.35$

Np ppb 65,900

Tc ppm 200

U-236 ppm 30,000

Assume U @ 62.5\% U-235

Assume Weapons Pu Dist

$\begin{array}{lr}\text { Pu-238 } & 84 \\ \text { Pu-239 } & 14 \\ \text { Pu-240 } & 2 \\ \text { Pu-241 } & 0 \\ \text { Pu-242 } & 0\end{array}$




\begin{tabular}{|c|c|c|c|c|c|}
\hline \\
\hline \multicolumn{6}{|l|}{ Chemical Forms of Uranium } \\
\hline $\mathrm{U}$ (metal) & UO3 & 0.83 & UF6 & 0.68 & \\
\hline UO2 & UF4 & 0.76 & UO2F2 & 0.77 & \\
\hline U308 & $\mathrm{UCl} 4$ & 0.63 & UO2(NO3)2 & 0.6 & \\
\hline \multirow{3}{*}{ U Enrichment $(\%$ U-235) = } & $\%$ U-235 & \multicolumn{4}{|c|}{ U SpecAct uCi/g U } \\
\hline & 78.2 & $5.09 E+01$ & Ratio & & \\
\hline & Code & DAC Value & Act to DAC & & \\
\hline Chemical Form of $U$ code $=$ & 0.83 & $3 \mathrm{E}-10$ & $1.70 \mathrm{E}+11$ & & \\
\hline SUM Constituent Act to $\mathrm{DAC}=$ & $2.32 \mathrm{E}+10$ & \multicolumn{3}{|c|}{ Fraction Dose from Constituents $=$} & 0.1369 \\
\hline \multirow{8}{*}{\begin{tabular}{|c} 
Constituent Data Units \\
Pu-238 \\
Pu-239 \\
Pu-240 \\
Np-237 \\
Am-241 \\
U-236 \\
Tc-99
\end{tabular}} & uCi/g sample & uCi/g U & DAC Value & \multicolumn{2}{|l|}{ Act to DAC } \\
\hline & & $0.00 \mathrm{E}+00$ & 3.00E-12 & \multicolumn{2}{|l|}{$0.00 \mathrm{E}+00$} \\
\hline & & $0.00 \mathrm{E}+00$ & $2.00 \mathrm{E}-12$ & \multirow{2}{*}{\multicolumn{2}{|c|}{$\begin{array}{l}0.00 E+00 \\
0.00 E+00\end{array}$}} \\
\hline & & $0.00 \mathrm{E}+00$ & $2.00 \mathrm{E}-12$ & & \\
\hline & & $0.00 \mathrm{E}+00$ & $2.00 \mathrm{E}-12$ & \multicolumn{2}{|l|}{$0.00 \mathrm{E}+00$} \\
\hline & & $0.00 \mathrm{E}+00$ & $2.00 \mathrm{E}-12$ & \multicolumn{2}{|l|}{$0.00 \mathrm{E}+00$} \\
\hline & & $0.00 \mathrm{E}+00$ & $3.00 \mathrm{E}-10$ & \multicolumn{2}{|l|}{$0.00 \mathrm{E}+00$} \\
\hline & & $0.00 E+00$ & $3.00 \mathrm{E}-07$ & \multicolumn{2}{|l|}{$0.00 \mathrm{E}+00$} \\
\hline & $\mathrm{uCi} / \mathrm{g} U$ & & DAC Value & \multicolumn{2}{|l|}{ Act to DAC } \\
\hline Pu-238 & $1.88 \mathrm{E}-06$ & & 3.00E-12 & \multicolumn{2}{|l|}{$6.27 \mathrm{E}+05$} \\
\hline Pu-239 & 5.87E-06 & & $2.00 \mathrm{E}-12$ & \multicolumn{2}{|l|}{$2.94 \mathrm{E}+06$} \\
\hline Pu-240 & $3.00 \mathrm{E}-06$ & & $2.00 \mathrm{E}-12$ & \multicolumn{2}{|l|}{$1.50 \mathrm{E}+06$} \\
\hline $\mathrm{Np}-237$ & $3.31 \mathrm{E}-03$ & & $2.00 \mathrm{E}-12$ & \multicolumn{2}{|l|}{$1.66 \mathrm{E}+09$} \\
\hline Am-241 & $0.00 \mathrm{E}+00$ & & $2.00 \mathrm{E}-12$ & \multicolumn{2}{|l|}{$0.00 \mathrm{E}+00$} \\
\hline \multirow{2}{*}{$\begin{array}{l}\text { U-236 } \\
\text { Tc-99 }\end{array}$} & $6.47 \mathrm{E}+00$ & & $3.00 \mathrm{E}-10$ & \multirow{2}{*}{\multicolumn{2}{|c|}{$\begin{array}{l}2.16 \mathrm{E}+10 \\
7.37 \mathrm{E}+03\end{array}$}} \\
\hline & $2.21 \mathrm{E}-03$ & & $3.00 \mathrm{E}-07$ & & \\
\hline
\end{tabular}

9212 HEU Process Stream 4 (ICPP + Data)

Assume

Pu ppb $\quad 0.11$

Np ppb $\quad 4,700$

Tc ppm $\quad 0.13$

U-236 ppm 100,000

Assume U @ 62.5\% U-235

Assume Weapons Pu Dist

Pu-238 $\quad 0.1$

Pu-239 86.1

Pu-240 12

Pu-241 1.6

$\mathrm{Pu}-242 \quad 0.2$ 


\begin{tabular}{|c|c|c|c|c|c|}
\hline \\
\hline \multicolumn{6}{|l|}{ Chemical Forms of Uranium } \\
\hline $\mathrm{U}$ (metal) & UO3 & 0.83 & UF6 & 0.68 & \\
\hline UO2 & UF4 & 0.76 & UO2F2 & 0.77 & \\
\hline U308 & $\mathrm{UCl} 4$ & 0.63 & UO2(NO3)2 & 0.6 & \\
\hline \multirow{3}{*}{ U Enrichment $(\%$ U-235) = } & $\%$ U-235 & \multicolumn{4}{|c|}{ U SpecAct uCi/g U } \\
\hline & 78.2 & $5.09 E+01$ & Ratio & & \\
\hline & Code & DAC Value & Act to DAC & & \\
\hline Chemical Form of $U$ code $=$ & 0.6 & $6 \mathrm{E}-10$ & $8.48 \mathrm{E}+10$ & & \\
\hline SUM Constituent Act to $\mathrm{DAC}=$ & $1.24 \mathrm{E}+10$ & \multicolumn{3}{|c|}{ Fraction Dose from Constituents $=$} & 0.1467 \\
\hline \multirow{8}{*}{\begin{tabular}{|c} 
Constituent Data Units \\
Pu-238 \\
Pu-239 \\
Pu-240 \\
Np-237 \\
Am-241 \\
U-236 \\
Tc-99
\end{tabular}} & uCi/g sample & uCi/g U & DAC Value & \multicolumn{2}{|l|}{ Act to DAC } \\
\hline & & $0.00 \mathrm{E}+00$ & 3.00E-12 & \multicolumn{2}{|l|}{$0.00 \mathrm{E}+00$} \\
\hline & & $0.00 \mathrm{E}+00$ & $2.00 \mathrm{E}-12$ & \multirow{2}{*}{\multicolumn{2}{|c|}{$\begin{array}{l}0.00 E+00 \\
0.00 E+00\end{array}$}} \\
\hline & & $0.00 \mathrm{E}+00$ & $2.00 \mathrm{E}-12$ & & \\
\hline & & $0.00 \mathrm{E}+00$ & $2.00 \mathrm{E}-12$ & \multicolumn{2}{|l|}{$0.00 \mathrm{E}+00$} \\
\hline & & $0.00 \mathrm{E}+00$ & $2.00 \mathrm{E}-12$ & \multicolumn{2}{|l|}{$0.00 \mathrm{E}+00$} \\
\hline & & $0.00 \mathrm{E}+00$ & $6.00 \mathrm{E}-10$ & \multicolumn{2}{|l|}{$0.00 \mathrm{E}+00$} \\
\hline & & $0.00 E+00$ & $3.00 \mathrm{E}-07$ & \multicolumn{2}{|l|}{$0.00 \mathrm{E}+00$} \\
\hline & $\mathrm{uCi} / \mathrm{g} U$ & & DAC Value & \multicolumn{2}{|l|}{ Act to DAC } \\
\hline Pu-238 & $1.88 \mathrm{E}-06$ & & 3.00E-12 & \multicolumn{2}{|l|}{$6.27 \mathrm{E}+05$} \\
\hline Pu-239 & $5.87 \mathrm{E}-06$ & & $2.00 \mathrm{E}-12$ & \multicolumn{2}{|l|}{$2.94 \mathrm{E}+06$} \\
\hline Pu-240 & $3.00 \mathrm{E}-06$ & & $2.00 \mathrm{E}-12$ & \multicolumn{2}{|l|}{$1.50 \mathrm{E}+06$} \\
\hline $\mathrm{Np}-237$ & $3.31 \mathrm{E}-03$ & & $2.00 \mathrm{E}-12$ & \multicolumn{2}{|l|}{$1.66 \mathrm{E}+09$} \\
\hline \multirow{2}{*}{$\begin{array}{c}\mathrm{Am}-241 \\
\mathrm{U}-236\end{array}$} & $0.00 \mathrm{E}+00$ & & $2.00 \mathrm{E}-12$ & \multicolumn{2}{|l|}{$0.00 \mathrm{E}+00$} \\
\hline & $6.47 \mathrm{E}+00$ & & $6.00 \mathrm{E}-10$ & \multirow{2}{*}{\multicolumn{2}{|c|}{$\begin{array}{l}1.08 \mathrm{E}+10 \\
7.37 \mathrm{E}+03\end{array}$}} \\
\hline Tc-99 & $2.21 \mathrm{E}-03$ & & $3.00 \mathrm{E}-07$ & & \\
\hline
\end{tabular}

9212 HEU Process Stream 5 (ICPP + Data)

Assume

Pu ppb $\quad 0.11$

Np ppb $\quad 4,700$

Tc ppm $\quad 0.13$

U-236 ppm 100,000

Assume U @ 62.5\% U-235

Assume Weapons Pu Dist

Pu-238 $\quad 0.1$

Pu-239 86.1

Pu-240 12

Pu-241 1.6

$\mathrm{Pu}-242 \quad 0.2$ 